\title{
EVERYDAY LIFE IN THE ANCIENT WORLD: FOUR RE-COLLECTIONS
}

by

\section{Lynn Jenner}

\author{
A thesis \\ submitted to the Victoria University of Wellington \\ in fulfilment of the requirements for the degree of \\ Doctor of Philosophy
}

Victoria University of Wellington 



\section{Abstract}

The thesis is made up of four separate but related texts recording the author's investigations of loss, searches and re-constructions. Questions of ownership are also examined, with particular reference to objects of cultural and artistic significance. The Holocaust is a major focus, especially attitudes of the New Zealand government and New Zealanders themselves to the refugees who wished to settle here before and after World War II.

The thesis is a hybrid of critical and creative writing. The first three texts, "The autobiographical museum", "History-making" and "Cairn", are also hybrid in genre, containing found text, new prose and poems, discussion of other writers' work and the author's experiments in 'active reading'. The fourth text is an Index which offers an alternative reading of the other three texts and helps the reader to locate material. While somewhat different from each other in form, all texts focus on the activity of gathering objects and information. All four texts are fragmented rather than complete.

Interviews with curators, education officers and CEOs in two Australian museums that have Holocaust exhibits provided information on the aims and processes of these exhibits. Meetings with six Holocaust survivors who act as volunteer guides in museums and reactions of visitors to the museums provided other perspectives on the work of the museums. The author also reports on visits to the Holocaust Gallery at the Auckland War Memorial Museum and the Holocaust Centre of New Zealand in Wellington.

Activity Theory, a cultural-historical model often applied to the analysis of learning and pedagogy, is used in the thesis as a metaphorical backdrop to the author's own activity. The author's focus on intentions, tools, processes, division of labour and financial pressures reflects the influence of Activity Theory as does the author's willingness to let understanding take shape gradually through tentative conclusions, some of which are later overturned.

Over the period of the research, records of the past are recovered and re-examined in the present, as was intended. Individual and collective memory, including archival records, fiction and poetry are resources for these investigations. The author receives an object lesson in the power of the informal networking role of the Holocaust Centre of New Zealand, as well as benefiting from its formal displays and materials. 
During the research the author writes records of the present because it seems necessary to do so. By the time the research ends, these have become records of the past an outcome which Emanuel Ringelblum would have predicted but was a surprise to the author. 


\section{Acknowledgements}

I would like to acknowledge the generous support of my supervisors Bill Manhire and Chris Price and my classmates from the International Institute of Modern Letters PhD programme. I am enormously grateful to my partner Tony Pine who encouraged me to begin this project and has supported my work in every way. Thanks to my mother, Lesley Jenner for her encouragement and to my sister Kerry for her practical assistance near the end of the project. I would like to acknowledge Tordis Flath who put her expertise in indexing at my disposal so that I could learn and who formatted this Index. Thanks also to Heather Elder who proofread parts of the text. Thanks to George Beran and other relatives of Karel Beran and to Kitty Hilton, Inge Woolf and Claire Bruell for their support with the project at critical points, and thanks to Ross Vinnell for conversations on the subject of risk. Thanks also to Navina Clemerson, Avril Alba and John Leuthart for feedback during the project and to Alison Chetwin for her active support during my time at New Zealand Police. Thanks to Jeanette Schollum, Lynn Davidson and Hinemoana Baker for listening and sage words. I received financial support from the Victoria University Faculty of Humanities and Social Sciences Research Fund for fieldwork during this project. 
Table of Contents

\section{Page}

$\begin{array}{ll}\text { Abstract } & 1\end{array}$

Acknowledgements 3

For the avoidance of doubt $\quad 7$

Foreword 9

Part One: The autobiographical museum 31

Part Two: History-making 105

$\begin{array}{ll}\text { Part Three: Cairn } & 177\end{array}$

Part Four: An Index $\quad 259$

Report on experience: An afterword $\quad 273$

$\begin{array}{ll}\text { Appendix } & 279\end{array}$

Works Cited 285

Selected Bibliography 293 


\section{For the avoidance of doubt}

Everyday Life in the Ancient World: Four Re-Collections is a fully hybrid critical and creative thesis, made up of four texts.

The Foreword provides some context for the thesis itself. It outlines the origins of the project, literary influences on it and my intentions for the project as it developed. It describes my research and writing methodology. It contains some reflections on the difficulties of writing 'about' the Holocaust as I understood this problem in February 2013, the time at which the thesis was submitted. The final two potential problems in this list are an exception though, having been added in May 2013 as a result of readings suggested by the examiners. The Foreword also discusses genre and spelling and gives an overview of the structure and form of all four parts of the thesis.

The afterword, named "Report on experience" as a respectful tribute to John Mulgan, looks back on the four parts that make up the thesis, from the position of February 2013.

I am very grateful for the examiners' added resource suggestions, especially the work of Saul Friedlander and Claude Lanzmann. I have added these later resources and other references I found as a result of these suggestions to the Selected Bibliography. These additions are marked with an asterisk.

Readers who wish to engage only or first with the thesis should turn to page 31 .

Lynn Jenner

June 2013 


\section{Foreword}

\section{Origins}

This dissertation began as two intentions: to write an exploration of 'missing people' and to use the form, style and structure of my exploration to echo experiences of loss and absence. I was interested in making work which requires the reader to be active in creating a personal and context-specific understanding of the text: what is present, what is absent and what these inclusions and absences mean.

I had not settled on any genre for my creative work. Dear Sweet Harry, my first book, contained poems, found text, prose narrative and images. It was described by others as a collection of poetry, as a long poem and as a mixed genre work. Although it won a prize in the category of Poetry, I thought of it as a non-continuous narrative, hovering on the edge between fiction and non-fiction.

I chose missing people as the subject of my dissertation because of the emotional significance this topic seems to possess in my own and in the collective imagination. My intention was to use the whole notion of 'missing people' and 'search and rescue' to help me notice different forms of people being lost and searched for, which I could investigate and report on. So, although I had not settled on a genre, there were clear signs from the beginning that the work was going to be related to research about missing people and would be attentive to the process of that research.

In terms of the critical component, I imagined I would write a separate section of literary criticism in which I would examine techniques used in the work of some particular writers whose work contained multiple perspectives and voices, fragmentary structure, and a strong emphasis on historicity and cultures. W. G. Sebald's The Emigrants was the first such work that I had identified.

I was interested in how, in The Emigrants, Sebald gives the impression of people in extreme distress without ever referring to that distress. I was interested specifically in Sebald's use of objects and places and dates in the text as symbolic evokers of mood. Sebald described his use of symbols in an interview with Eleanor Wachtel:

People always want what seem to them to be symbolic elements in a text to have single meanings. But of course that isn't how symbols work. If they are any good at all they are usually multivalent. They are simply there to give you a sense that there must 
be something of significance here at that point, but what it is, and what the significance is, is entirely a different matter. . . I think that it was a question of trying to find, in a text of this kind [The Emigrants] ways of expressing heightened sensations, as it were, in the form of symbols which are perhaps not obvious. (Wachtel 53) I began my thinking on this question about The Emigrants by making a copy of the opening section of the text of "Dr Henry Selwyn" and expanding it to include visual images and small background summaries of each object that was mentioned to better understand the associations of these objects for a northern hemisphere reader, or a reader with knowledge of northern hemisphere objects.

However, while I was beginning this critical work, and before any creative work had been done, one of my supervisors suggested I read Anne Carson's If Not, Winter. I was impressed, as anyone would be, by the beauty of these translations; both the language and also the appearance of the poems on the page. But I was at least as interested in the stories of the fragments themselves. My response was to begin research into the processes by which the fragments are known to us. This research was recorded in new writing which is critical in the sense that I scrutinise received versions of facts and investigate the cultural and historical contexts that have influenced assumptions and actions. Writing about this critical thinking process represented a shift away from the examination of literary techniques which I had imagined would make up my critical work in the PhD.

The first of the hybrid critical and creative pieces were "Mysteries and speculations" and its neighbour, "Three re-constructions", from "The autobiographical museum". The hybrid focus seemed to allow me to pursue serious topics such as cultural appropriation and ownership in literary and other contexts in a new way, adopting a tone with elements of action and playfulness, locating strange and true information and showing it to the reader. The focus on intentions, tools, processes, division of labour and financial influences that was present from the start of this work reflects the influence of Activity Theory, as does the willingness to let understanding take shape gradually through tentative conclusions, some of which are later overturned.

Clearly some sections of the dissertation lean more towards critical than creative activity. The section in "Cairn" describing New Zealand's immigration policy relating to Jewish refugees from fascism before and just after World War II (203-4) is an example. 
However my general aim is that critical and creative elements are integrated to the point where it is not possible to distinguish much of the work as exclusively 'creative' or 'critical' in intent. I would see the section about Bruno Schulz's mural (85-94) and the poems made from Glenn Kurtz's article (48-53) as examples of completely hybrid work.

The hybrid critical and creative form that characterises this dissertation developed organically, from the ground up, in close association with If Not, Winter. With hindsight it does not seem surprising that an association with work by Anne Carson would produce experiments in genre.

Focusing on Anne Carson's translations of the fragments of Sappho, particularly on different ways the fragments have been treated over time and on the methods of locating papyrus in the Egyptian desert, widened the thesis content from 'missing people' and 'search and rescue' to 'loss, searches and re-constructions'. "The autobiographical museum" maintained the original core intention to create a text which represented loss and absence. Once I saw the work which is called "The autobiographical museum" emerging, I realised I was selecting and curating my own and other writers' texts as objects, rather as a curator of an exhibition in a museum or a gallery might select and curate historical or other objects. A willingness to leave room for new ideas to come in to the work from the bottom up, through reading and writing practice and through deliberate site visits and interviews rather than 'top down' from a theoretical or genre-based template, has continued throughout the project. The fact that my chosen topic is general rather than specific has meant that this approach, of bringing situations I came upon into the writing, was useful and perhaps even necessary.

After writing "The autobiographical museum" I decided to pursue this hybrid genre and curatorial approach for the entire thesis, although I could not foresee exactly what the outcome would look like. My new intention, which I outlined in my research proposal at the end of the first year, was to create three text objects, designed to resonate with each other as objects in an art exhibition do, each object capable of standing alone, but forming a larger picture when placed side by side. I hoped that this would give me the opportunity to use form differently in each piece, but always acting out a rejection of completeness and simple interpretations. I aimed to place different topics in the foreground in each piece, but join the three parts and their various sections of content through their relationship to loss, search and re-construction. 
Relatively late in the process, after the three texts had been drafted, an Index was added to the plan. In the current order, the Index is the final of the four Re-Collections. The Index displays the preoccupations of the other texts; remixes these alphabetically and reminds readers of relevant dates, books, authors and places. It is the ultimate list in writing with a clear interest in lists. It is the 'whakapapa' of the work too, reciting the names of books and writers and events which have gone before, making possible and eventually causing, the birth of this work. The Index also fulfils the conventional requirement to help readers to locate particular topics in the texts. 


\section{Literary influences}

During the project, Patrick Modiano's The Search Warrant and H.G. Adler's Panorama have been significant resources for form and structure and for their richness in psychological, cultural and historical context, a feature I look for in my own reading and aspire to in my writing. They also hover between fiction and non-fiction, containing elements of both. This matches my view that since facts and fiction are not entirely distinct from each other, a total separation into genres of fiction or non-fiction is artificial and, more than that, misleading. As James Young says, "If there is a line between fact and fiction, it may by necessity be a winding border that tends to bind these two categories as much as it separates them, allowing each side to dissolve occasionally into the other" (52).

Orhan Pamuk has described the mood-creating role of objects in novels in The Naïve and Sentimental Novelist. In novel form and then in a physical museum, The Museum of Innocence illustrates his fascination with the role of objects. An interest in objects, which I caught from my early archaeological reading, combines with my own longstanding engagement with museums to make a major element of my writing in the dissertation.

The numbered and curated texts of David Shields's Reality Hunger: A Manifesto appealed visually. However my interest in context forced me to look up the source of each numbered section in the back of the book. This disrupted sustained reading. David Markson's use of the Holocaust as a theme in Reader's Block made a deep impression on me as a Jewish reader. As a reader, I enjoyed learning new facts and connections. 


\section{Intentions}

I see my work as creative and critical writing, rather than as a work of psychology, cultural studies, museology or historiography, although clearly it has connections to all these fields.

My intention in these four texts is to make a new 'story', which joins old stories and contemporary stories from New Zealand and from other places. A Jewish friend said after reading "Cairn" that she regards New Zealanders as 'dangerously naïve'. Reading Jessica Caldwell's thesis Holocaust Consciousness in New Zealand 1980-2010, the words 'ignorance', 'apathy', 'indifference', as well as many mentions of the word 'isolation', struck me as significant.

I am interested in the cultural effects of New Zealand's literal isolation. I wonder if or when physical isolation over which New Zealanders had no control, and which has often been felt as a painful distance from families in Europe, evolved into a deliberate use of distancing as an aspect of the consciousness of New Zealanders. I am also interested in the silence that surrounded everything Māori in the Pākehā New Zealand of my childhood.

I hope that the work in this dissertation has enough mobility to place itself in New Zealand now, to look back in our history and to be 'about' New Zealand and other places simultaneously. I hope it has enough depth to do this in a worthwhile way and enough unity to form a narrative, albeit an incomplete and provisional one.

It is not my intention to provide a comprehensive account of historical or literary events which are mentioned, but rather to cut a subjective path through a series of experiences and to report on that process to the reader as it unfolds. In line with this, there is no formal Literature Review as a separate part of the dissertation. Instead, critical research and works of art are inside the texts or behind them in background provided by the Selected Bibliography. 


\section{Methodologies}

This section outlines the method used in fieldwork I have carried out as part of this project. It describes ethical positions I have taken in the thesis, both in the formal sense of university research requirements that apply to situations I deliberately created in order to gather information, and in the wider sense of decisions made in the course of the thesis, but outside of university requirements.

\section{Planned fieldwork}

When I planned the related-objects structure, one chapter was to focus on memorials in writing and in other forms to Jews who died in the Holocaust. I chose to use visits to the Sydney Jewish Museum, the Jewish Holocaust Centre in Melbourne, the Australian Jewish Museum in Melbourne, the New Zealand Holocaust Centre in Wellington and the Auckland War Memorial Museum as part of the background for this writing.

In Sydney and in Melbourne these visits included formal interviews with managers, curators, educators, archivists and, in one museum, a volunteer coordinator. My main interests were the intentions of these museums, how they went about their programme and how, exactly, they intended exhibits in the museum and education programmes to make events like the Holocaust less likely. Some version of this goal is always part of the mission of Holocaust Museums, and I wished to investigate the logic of their activities directed towards this goal. The Jewish Holocaust Centre and the Sydney Jewish Museum both use volunteer Holocaust survivor guides, and I planned to interview some of these survivor guides about why they do this work and what outcomes they see from their work.

Because I intended to interview museum staff and volunteers, it was necessary for me to seek approval from the Victoria University Human Ethics Committee for the process by which this information would be collected. This was granted in August 2011.The conditions of this approval included the requirement for each interviewee to receive information about me and my project, for each interviewee to give informed consent to be interviewed and for each interviewee to receive a copy of the interview notes if he or she wished. When interviewees asked for copies of the notes, I offered to supply a draft for checking and possible correction. The Ethics Committee Approval of my research, and the Information Sheet and the Consent Form that I used in my application to the committee are included in the thesis as the Appendix. 
At this planning stage I was anxious about every aspect of writing about the Holocaust. I will describe these anxieties in more detail later in this section. I also refer to them in "Cairn" (188-90). In particular, at this early stage, I was concerned that the topic of the Holocaust would be so overpowering that I would not dare write any of my own words. With that in mind, I made a constraint in the form of a condition in my information sheets that I would not quote any of the interviewees without individual and institutional permission. I hoped that restriction would lead to more processing on my part, which would give me the confidence to write about what I learned in my own terms.

I had no difficulty following the 'informed consent' procedure with the paid staff of the museums. However, when it came to the six volunteer survivor guides I met, I was not able to direct them into a formal process. They were accustomed to following a certain pattern of activity that involved being present in the museum and making themselves available to the public by taking the initiative and starting a conversation. I was never able to stop this process, give information and obtain informed consent for my conversations and then carry on with an 'interview'. In fact I would not say that I interviewed them at all. It would be more accurate to say that they told me what they wished to tell me, how and when they wished to say it. Some of them asked me questions, effectively turning the process into them interviewing me. Some of them asked me if there were any questions I wished to ask, and sometimes I took advantage of this. I have described the dynamic between myself and the survivor volunteers in the section titled "This Crazy Thing a Life" in “Cairn” (234).

When I was doing background preparation for my project, I had asked relatives of survivor guides and museum staff if the survivors would be likely to agree to speak to me and they had said things like "Oh yes, she'll talk to you. She talks to anyone." I did not really understand this sort of comment until I saw the survivor guides at work in the museums.

Ethics requirements in a university context where protection from harm and privacy are priorities, and the aims of volunteers who offer themselves to the public and tell quite intimate stories of their experiences, seemed to clash directly in this piece of my fieldwork. Being unable to follow an 'informed consent' procedure with the survivor guides, as I had undertaken to do, left me with a sense that since this research was part of a PhD process, I should approximate the university requirements rather than what the survivors might have 
wanted. With this in mind, I have not used the names of any of the survivor volunteers in my text and have not identified which scene happens in which museum.

Although I was not required to do this, I sent a draft of "Cairn" to the Sydney Jewish Museum and to the Jewish Holocaust Centre in Melbourne for feedback. In each case I asked for any errors to be pointed out and offered to make changes if requested.

No text changes were requested by either institution. I did not send a draft to the Australian Jewish Museum because my interviews with staff there provided only general background related to exhibit and public event planning and the work of curators.

I visited the Auckland War Memorial Museum and what is now the New Zealand Holocaust Centre after the Australian museum visits. As a result of my Australian experiences, I had decided to take a different approach to these visits. This time I wanted to visit as a member of the public; to have the 'visitor experience' without commentary, so that I could form my own relationship to the exhibits, architecture and resources. My assumption in the work which describes these two institutions is that everything I describe is part of the public exhibit, or was at that time, and therefore does not require specific consent or consultation.

\section{Informal fieldwork}

In the process of my research I also happened upon stories and material that led the research and the writing down unforeseen paths. The most significant of these is the story of Karel Beran, which appears in "Cairn". This story begins with a visit to the Auckland War Memorial Museum during which I see an urn that was part of the Holocaust exhibit, continues as I locate Karel Beran's oral history interview about his life during the war, and ends, in "Cairn", with me intending to make contact with his descendants. (In real life I have spoken to Karel Beran's son several times over accuracy and permission to tell Karel's story, but the story of "Cairn" stops before this.)

I am very grateful to have come upon this story. I think of this learning process as an enactment of how museums and archives support research and also how they work as custodians of collective memory. In this case the urn in the Auckland War Memorial Museum piqued my interest. Visiting the Holocaust Centre in Wellington allowed me to ask about the urn in a supportive context, and I benefited from the Holocaust Centre's links to the Holocaust survivor oral history group in Auckland. A member of this group told me 
about Karel Beran's oral history interview, which she said was held in the National Library, and helped me contact Karel Beran's family.

I found Mr Beran's videotaped oral history interview at the National Library and in the Victoria University Library. No specific permissions are required to view it. Watching it took several hours. On one occasion I watched it under the supervision of the National Library staff, on their premises, seated next to another researcher who was watching something very funny. On another occasion I watched the interview in the University Library on a television which gave Mr Beran's body an outline of fluorescent green and three shadows. On the third occasion I borrowed it from the University Library and watched it in my lounge at home, sitting on the same couch I sit on to watch sitcoms.

Seeing an old man doing his best to tell his story clearly and seeing that he made himself vulnerable by doing this left me with a feeling that I had a responsibility to this man to treat him and his story with care. Since Karel Beran was dead, I made a decision to make contact with his descendants and ask for consent for my particular use of the interview. I had found in my contact with museums that it was impossible for them to imagine how Holocaust museum exhibits could figure in a work of creative writing and I wondered whether, for the Beran family, the somewhat informal and personal nature of my work would be seen as an appropriate context for this very serious story. When I first contacted George, Karel's oldest son, he told me that another writer had included mention of Karel Beran in a book published just a year ago, on a completely different topic, without ever telling anyone in the family that he was doing this, and that they were grateful to be consulted in this case.

I provided a draft of "Cairn" to George Beran in June 2012. In September 2012 he pointed out one error of fact. In a phone call in October 2012 he gave consent for his father's story to be told in the thesis and in any later publications based on the thesis. Later in October 2012, I received an email from Karel Beran's daughter-in-law Kate, saying, "It's certainly a well researched and analysed series of fascinating aspects of relocated people. We have all enjoyed reading it and would be very happy to meet up with you if you are in Auckland"(Casey).

The stories concerning my mother and the earthquakes were also informal fieldwork in the sense that they are unforeseen experiences which occurred during the research 
process and led the text into new territory. My mother has seen "History-making" in draft and given her consent for these stories to be told in this thesis.

\section{Methodology in my own writing}

I have assumed that it is reasonable in a piece of critical and creative writing to examine other published writing closely and to describe a personal response to it. In the thesis this personal response takes various forms. When I have wished to take issue with some aspect of a piece of writing, as I have done with Michael King's At the Edge of Memory, I have provided my line of argument together with references to King's text, so that the reader can make up his or her own mind about the position I have taken. I do not pretend that my view of this book is objective, but I have aimed to make my view clear. 


\section{Writing about the Holocaust}

With respect to writing about the Holocaust, there is a large literature on artistic and ethical considerations and risks. Summarising these briefly, a writer can expect criticism if the work:

- exploits the suffering of victims in order to create an audience;

- lapses into tastelessness or vulgarity, thereby coarsening the collective memory;

- creates beauty for a reader to enjoy out of the experiences of victims, and takes away the horror;

- creates a feeling for the reader that something good comes out of the disaster of the Holocaust;

- contains a sense that the Holocaust can be understood or conveyed in words;

- attracts readers with the glamour of Nazi pageantry and trappings;

- makes violence erotic;

- shows that the author identifies him or herself excessively with the victims, when he or she is not a victim;

- seems to blame the victims for not knowing what every reader now knows, implicitly inviting the reader to join the author in a patronising stance towards the Jews of prewar Europe for not seeing what was coming soon enough to save themselves;

- points to historical moments in a way which gives them more historical significance than they had at the time;

- uses the Holocaust, which had not happened yet, to judge everyone's behaviour in the period leading up to the Holocaust;

- is inaccurate;

- conveys, by its unchallenged use of the official language of Nazi officials or their subordinate regimes, that their actions were 'normal';

- conveys, by the orderliness of its account, that the Holocaust is concluded and exists only in the past.

Fiction depicting the Holocaust has attracted the most virulent criticism, but all forms of artistic representation have provoked intense scrutiny. Faced with this list, "a certain thematically weighted and deliberately chosen silence is sometimes seen as the only ethically unsullied response that art can make to the Shoah" (Bernstein 43). 
Despite this, I have taken the decision that it is reasonable from an ethical point of view to write about events or works of art (related to the Holocaust) that I have seen or heard or read about, and about policy and attitudinal issues related to the Holocaust survivors in New Zealand. I never considered writing about exactly how people died, not because it is often mentioned as a taboo, but because I do not see myself as having anything to say about this subject. I have not added any elements of fiction to my accounts of Holocaust events. I have added some fictional or metaphorical elements to descriptions of my own experience of learning about Holocaust events.

I tried to keep "Cairn" from becoming didactic or rigid under the weight of this topic, but have noticed that my writing on this subject has taken on a square, monolithic and serious quality. "Cairn" also grew to be significantly larger than any of the other chapters, and could be larger yet.

The tendency of Holocaust narratives to be in memoir form to prevent allegations of fictiveness in relation to the Holocaust itself has been widely described, as has the tendency for fictional narratives of the Holocaust to incorporate some form of testimony in order to shore up their authority (Young 51-63). Given my early reservations about using quotations to remove any easy options for myself, the introduction of a long passage of quotations from Karel Beran's interview near the end of "Cairn" could be seen as surprising. The inclusion of the quoted material was partly a political decision to place a survivor voice in a prominent position and to give survivors the 'last say'. It was also an artistic decision because the interview contained references to places and objects that resonated with my own narrative, such as the fire-bombing of Dresden, the context for the removal of ashes from Birkenau, and reference to the significance of objects such as the Skoda sports car. It also connects the Holocaust to New Zealand, brings the actual events of the Holocaust down to a personal scale and therefore brings the reader closer to the Holocaust than previously. I did not consciously include this material to give extra authority to my own text, but certainly it adds a perspective I could not provide and, whether I intended or not, it adds realism, which is a form of authority. 
Genre

Activity Theory sees genre as specific to a time and place - more a life form than a type of text. Genre in this context is a tool, one possible way in which a group acts together to further its aims. Because they are part of a thesis, my four texts are to some extent academic documents. They therefore retain the academic genre convention of acknowledging texts by other authors. However, as a researcher, I learn equally willingly from academic texts, historically verifiable stories, the structure and colours of buildings, art- works, fiction, conversation and gossip. My own texts reflect this. They contain many voices, reported in varied styles, none of which is seen as immune to contextual influences.

In terms of genre, I see this set of four texts as memoir, but not purely memoir. In the Preface to their book about Czernowitz, Hirsch and Spitzer provide this introduction to their work: "Family narratives are important components of Ghosts of Home, but this book is not a family chronicle. Instead, we think of it as hybrid in genre - as an intergenerational memorial and an interdisciplinary and self-reflexive work of historical and cultural exploration" (Introduction xx).

This description orients the reader to complexities that prevent the assignment of a single genre identity to their work. Like Hirsch and Spitzer, I would reject a single genre identifier for my work. If I were to attempt a discipline-based description of its approach I might call it a 'self-reflexive psycho-developmental and socialist work of literary, cultural and historical research'. Calling it a story is shorter. It is also congruent with my aim that these texts are first and foremost writing, intended to be shared with readers. The fact that the author has a varied discipline background, which shows in her research methodology, is part of the character of the text but is not the point of the text. 


\section{Spelling and other textual considerations}

The order of the chapters in the PhD dissertation takes the reader on a particular path, but a reader may not wish to read all four, or may wish to read the texts in a different order from the thesis, and I would like to allow for this in later versions. Throughout the project, I have kept open the idea that the texts might, after the PhD, be published as separate booklets, perhaps in a box, rather than bound together as one book, and/or in a digital form containing hypertext that permits and encourages searching and allows the reader to see images or other texts as I refer to them.

The texts include European place names and words in other languages, including Māori, Yiddish and German. Names of places, gods and people can have many possible spellings, depending on the language being used and the time period being discussed.

In addition, Yiddish words are often spelled several different ways in English because Yiddish is written in a Hebrew alphabet and therefore transliterations into English are approximations of Hebrew sounds.

I use the spelling used by the person speaking. When I quote from another writer, I use the spelling and punctuation of the original text. This means, for example, that I use 'Czernowitz' for the place now called Chernivtsi, because Hirsch and Spitzer are examining the phenomenon of the memory of a place that was once called Czernowitz and was called this long after its name officially changed. Similarly, I use 'Bolechow' for the place now called Bolekhiv, because Mendelsohn refers to it this way in his historical re-construction. Mendelsohn in turn uses 'Bolechow' because his grandfather called it that.

This rule can mean that a word will be spelt more than one way in my text, for example the city of Drohobych. I use its contemporary name, transliterated from Ukrainian, but Yad Vashem refers to the town as 'Drohobycz', the Polish spelling, because the town was in Poland before World War II. I use Cowan's spelling of Māori words when I am quoting or describing what I have learned from his work. I have not used macrons for my descriptions of the 1960s but have incorporated macrons when I am speaking in my own contemporary voice. I have tried to enact in my text a sense that for a certain time we are in one particular world. I see this as a live example of historicity and the significance of context.

The success of work like these texts, which are constructed from fragmented elements, depends considerably on the placement of each element vis-à-vis the others. 
Overall I have used personal emotional connections to guide the juxtapositions. I have also used textual resonances between pieces to suggest placement, such as the fiery death scene at the end of "Looking back from the Island" leading on to the beginning of "Hair" in "Cairn" (182-183).

I hope that these texts will generate an active reading experience, sometimes relatively puzzling and at other times clearer, from which a reader will emerge with his or her own interpretation of what the collections mean at the time of reading and in the circumstances and place of that reading.

In line with the absence of didactic purpose, the work never contains a simple summing up of what these four collections of activities and descriptions add up to. Although "Cairn" contains a personal summing up near the end, it is not presented as something readers would necessarily agree with, and the presence of two possible endings acknowledges that I may not agree with it myself after time passes and other experiences offer new perspectives. 


\section{Chapter overviews}

The following section provides an overview of the content and form of each chapter.

\section{The autobiographical museum}

\section{Content}

The title provides a clear message that all the objects in this museum of text have been chosen by one person, are seen by that person as significant and make up some sort of reflective representation by that person of her own life. The first exhibit is the author as a child, reading and re-reading a book about ancient time. Within a short space, the Anschluss has appeared, paired in time with the passing of the Social Security Act in New Zealand, and the reader is shown some objects from antiquity exhibited in the British Museum. This threesome is shorthand for the Holocaust, the Labour movement in New Zealand, and archaeological practice, important preoccupations of all four chapters. It also represents the juxtaposition of events in New Zealand, events in Europe, events of the present or the recent past and ancient events.

Processes of what I term 'active reading' are also present in this chapter. During 'active reading' the author explores text by climbing inside it, taking elements chosen for particular reasons, and re-using them.

\section{Form}

The section opens with the establishment of a first-person voice, in prose. Within the first few pages, readers are introduced to the idea that there will be multiple voices in this work. There is a second form of prose narration, which is more informative than personal, and there are quotations. Each quotation is a new 'voice', bringing a new style and discourse, originating from someone other than the author. The quotations have been chosen to chime with the author's concerns, but not to repeat them.

As Engström says:

An original quotation, when it is not mishandled and mutilated so as to be totally subordinated to the single-minded purpose of the author, represents a voice and language of a researcher other than the author. It represents a dynamism of its own, never perfectly in line with the author's intentions. It allows for a variety of interpretations, not only the ones the author employs in his line of reasoning. (22) 
There are also poems written by the author and pieces of text in boxes. I have made spaces between quotations and defined boundaries for some text to create a sense of white space and silence, interspersed with words and voices. I could also describe the form of this chapter as tuning in and out of various voices as you move up to and then past lots of radio stations, each voice in the middle of speaking when you find it. I placed the Notes section at the end of this chapter so as to maintain the sense of surprise when encountering each voice and to keep the text clear of visual and explanatory interruptions.

If a reader begins with Part One, it will teach the reader how to engage with the material in all four Parts. The title begins this process. As the chapter progresses I hope the reader forms ideas about the sorts of text, ideas and objects to expect, and how to 'read' the juxtapositions to make sense of individual pieces, this chapter and the four Parts as a whole.

In terms of the degree of fragmentation, this chapter is in the middle. The material in "History-making" and "Cairn" is less fragmented than in this first chapter; the material in the Index is even more fragmented.

\section{History-making}

\section{Content}

The plan for Part Two was that it would be an investigation into the world of missing people. I began accumulating background from people who have been 'missing' or partly 'missing' and from books on the subject. However, before I managed to dig far into this topic, the first of the earthquakes in Christchurch happened and I was called away from my home and away from my own research activities to support my mother in Christchurch. Events in Christchurch continued to preoccupy me in late 2010 and through 2011.

These two topics, the earthquakes and missing people, one bursting in over the other, form the core of the content for this chapter. The earthquakes caused, among other things, the loss of the colonial buildings in the centre of Christchurch, much of the Christchurch I knew as a child, and my mother's diamond rings. This caused me to search my memories of that time and place for consolation and explanations. It also caused me to search for my mother's rings. In the process of trying to understand these earthquakes, I found James Cowan writing a book based on conversations with a Ngai Tahu kaumātua, Hone Taare Tikao (Cowan's spelling). Tikao tells Cowan of the traditional life of his people in the area of the 
Port Hills. By 1922, the time of these conversations, the trees, the birds and the villages have mostly vanished, casualties of colonial settlement. At the same time, in Russia, there was ruin, hardship, and the possibility of re-designing everything for the benefit of ordinary people. The first discussions of what became Activity Theory happened at this same time. Some of my personal experiences of people being lost are also re-told in this chapter.

The earthquakes, European settlement and my personal experiences of missing people are presented as versions of loss, searches and re-constructions. Tikao, whose knowledge extends further back in time than any other source, alludes to the disappearance of other peoples and their ways of life before these.

\section{Form}

This chapter is a series of prose sketches or vignettes of varying lengths, loosely grouped around the earthquakes and losses consequent on the earthquakes, attempts at preservation and methods of recording history. Each of these is narrated in the first person. There are also some small 'penetrations' in the form of poems, poem fragments or song fragments.

My intention is that the author is more visible, emotionally closer and less in control than in "The autobiographical museum". The primary focus of the vignettes is on stories of individuals, against a background of large scale events, with neither the individual nor the large events taking precedence over the other.

I intend that the writing in "History-making" is more 'joined up' and so, in one way, more straightforward than in "The autobiographical museum", with the breaks between sections of the text standing in for the fact that events do not proceed as one expects and therefore records of fresh experiences cannot be coherent. I want to convey that coherence can only be found post hoc, as Ringelblum says, and even then, interpretation needs to be seen as provisional because it occurs in a cultural and historical context.

"History-making" is intended to make sense without recourse to the Notes. With that in mind I have placed the Notes at the end of the chapter so that they will not interrupt the reader unless the reader makes a deliberate decision to consult the Notes section. Notes relate mostly to Cowan's book and to the Ringelblum Archive. In these sections the reader is possibly being given new information and may wish to add depth by consulting the Notes. 


\section{Cairn}

\section{Content}

This chapter is an investigation of the Holocaust from the perspective of the author, who lives in New Zealand and has not visited Europe except in fiction and poetry and film. In addition to the Holocaust, the narrative shows an interest in histories of the local Kāpiti area and in current activities aimed at reconstructing the botanical environment of pre-colonial time. The narrative focuses on those aspects of the Holocaust in the author's view: the New Zealand government's behaviour towards the Jewish refugees who survived the Holocaust and wished to settle in New Zealand; Australian and New Zealand museum representations of the Holocaust; and New Zealanders' attitudes to the Holocaust. The investigation uses information from libraries, museums, newspapers, fiction, memoir, poetry, documentaries, historical texts, photographs and real people. Michael King's memoir, At the Edge of Memory, in which he researches the history of his great-uncle by marriage and reflects on anti-Semitism in New Zealand, is a focus of critical attention.

The story of Karel Beran is another focus of this chapter. Karel Beran, a Jewish Social Democrat from Bohemia, went back to Auschwitz in 1946, just over a year after being released, to gather ashes from one of the crematoria at Birkenau. When he came to New Zealand after the war, he brought some of those ashes with him.

This chapter also refers to four absent texts written by the author: an un-named radio play, the play And also it was cold there in the winters, a poem in the shape of a brick and a translation of a poem by Rose Ausländer. This is a continuation of my earlier activity of researching texts and events by climbing inside them, but in this chapter I place these text experiments in the background rather than the foreground of the narrative as in "The autobiographical museum".

\section{Form}

This chapter is a first-person prose narrative describing a sustained personal and reflective investigation of aspects of the Holocaust. The investigation concentrates around particular topics described in individually titled sections. Fragments of poetry sit inside some sections, usually as a concentrated illustration of something which is talked about in the prose text. There are four lists in this chapter: whalers from the Kāpiti area, native trees, 
notable suitcases and research rules. There is also an account of, and excerpts from, an oral history interview carried out by the Shoah Foundation in 1997 with Karel Beran.

This chapter contains a critical investigation of Michael King's book At the Edge of Memory. I have used footnotes in preference to end notes or in text citations in this chapter so that the reader can easily follow the arguments I am presenting and in order to give the text a somewhat dated, rather than a contemporary, look.

\section{The Index}

The Index is an alternative way to read Everyday Life in the Ancient World; a metatext. It is intended to be a chapter in its own right, with as much interest and significance for a range of readers as any of the other chapters.

\section{Method}

I selected the entries in the Index, the logic of the headings, subheadings etc. and its format and style. Tordis Flath, an experienced professional indexer, was contracted to input the entries into SkyIndex. SkyIndex generated the Index as it appears in the thesis. Tordis advised on indexing conventions but responsibility for all content decisions is mine.

The fact that the author of the text has selected the entries for this Index takes away the 'objectivity' that professional indexers aim to bring to the task, and puts in its place another opportunity for the author to emphasise some things and reduce emphasis on or remove other things.

I have, for example, indexed fictional characters as if they were people and I have used the descriptor 'Holocaust survivor' to emphasise this aspect of certain people's lives. I have not indexed individual Nazis such as Felix Landau and have not focused much on Nazi activities such as concentration camps. Certain possible headings such as 'Holocaust' have the potential to overshadow other subjects. With this in mind, I have kept the heading 'Holocaust' very brief.

I attempted and failed to index the heading 'loss'. I have commented on this in the Index. I have focused on historicity, on processes and on equipment. I have also focused on books and activities associated with books. 


\section{Everyday Life in the Ancient World}

\section{Part One: The autobiographical museum}

Quotes are justified (to show their canonical quality) and my contributions are unjustified. No pun intended. 


\section{Foreword}

Because the text of spring is marked by hints, ellipses, lines dotted on an empty azure, and because the gaps between syllables are filled with frivolous guesses and surmises of birds, my story, like that text, will follow many different tracks and will be punctuated by springlike dashes, sighs, and dots. ${ }^{1}$

Bruno Schulz 
As a child I had a book called From Ur to Rome. White sand fell from the binding. Black birds stood on one yellow leg; the other leg bent and stretched in mid stride. Each bird had one round orange eye. Swallows arrived in spring, so many that they darkened the sky, sweet water flowed underground and the black centre of each of the painted eyes of the dead queen was a forbidden cave.

From Ur to Rome, by K.M.Gadd. London: Ginn and Co., 1937. ${ }^{2}$

This textbook tells the story in language suited to eleven year olds, describing the everyday life of the people in the ancient world rather than their political history. A surprising amount of detail is given in so short a sketch, and the book is well illustrated. . It is designed to serve as a quarry in which the pupils can search for answers to their own questions. . .

Lying on my stomach on the floor wherever a square of sun fell down, I read and re-read this book. After a while something different happened. Sometimes we would move to a different house. Sometimes a new book would arrive, and I would switch my allegiance. Sometimes I would wear out a book before anything different had happened, and my parents would take me into town on the bus on a Friday night, to see if they could buy another copy for me.

In this way they taught me, although, in the style of those times, nothing was said, that each time you read a book, you read it differently. 
1938: the year the first New Zealand Labour government passed the Social Security Act and the year of the Anschluss. The Classical Association's unnamed reviewer appreciated the emphasis Kathleen M. Gadd placed on the everyday life of people in the ancient world, this life being understood and explained through the production of drawings and photographs of objects from that time. 
Everyday life: Objects of human rather than artistic interest ...

1. A spinning top, terra cotta, eighth century B.C.E.,

2. Doll with castanets, terra cotta, circa 350 B.C.E.,

3. Baby feeder, pottery, fourth century B.C.E., with inscription, 'drink don't drop',

4. Miniature wine jug, 425-400 B.C.E.,

5. Rattle in the form of a pig, terra cotta, third-second centuries B.C.E.,

6. Two figurines: a woman grinding grain and another baking bread.

Grouped in this case by the British Museum in 2001, under categories such as 'sacrifice', 'gods', 'reading and writing', 'women', 'trade and transport'.

No category for 'slaves', 'foreigners' or 'torture'. ${ }^{3}$ 
In $\mathbf{2 0 0 8}$ I made a list of all the books I have worn in and worn out to see if they had anything in common. How lifeless my fetish objects looked in this list, but how each had shimmered and glowed in its day. Why does a book appeal so much at a particular moment in my life?

The list of worn out books exists. That is a fact. This list is a guide to my life and, at the same time a record of it, following every turn and twist as closely as my bank statements. The journey marked out by all those books is strange, unintentionally amusing and informative in its own way, but in another way, as puzzling as if there had been no record made.

At the age of nine I went on record, saying to George Ashton, the principal of my primary school that I wanted to 'be' an archaeologist. He went on record too, saying that I could 'be' anything I wanted. Looking back, I see that archaeology has always been my intent, although my activities went under different names at different times. 
Freud had a collection of small objects from antiquity, some no larger than a chess piece, some a few inches tall, arranged in a line on his desk in Vienna. He would have seen these vases and human figures whenever he raised his eyes from his writing. Also on his desk: a clock, a lamp, a knife to open letters and some other objects whose purpose I do not know. I imagine they are, in some way, tools of writing, but they could also be medical implements used in his work with patients or on himself. In June 1938, Freud left Vienna, accompanied by his wife Martha, his daughter Anna, two maidservants, his chow and his doctor. They were met in England by other members of the family who had come to England earlier. At first the family lived in temporary accommodation. But in their house in South Hampstead Freud's son Ernst reconstructed the old man's Vienna office. Freud's desk, where all his precious objects stood in a line in front of the blotter, was just as it had been, even if its context was very different. As a middle-aged woman I interpret Ernst's action as a gesture of kindness, but perhaps filial piety might be more accurate.

Freud described analysis as a form of archaeology. I felt a small movement inside my body when I read this, as if the tongue of a lock had emerged from its cavity, extended itself towards a new place, found that it fitted and settled there. 


\section{Sir Leonard Woolley:}

I must emphasis strongly one thing. All excavation is destruction. The archaeologist unearths a building, perhaps removing two or three later constructions in order to do so; its walls remain and can be seen or, if the wind-blown sand covers them again, they can be dug out a second time, but all the evidence given by stratification, by the position of objects, by traces of wood ash or by fallen brickwork, this has gone, and can never be recovered; he digs out a grave and all that remains is a hole in the ground and a group of objects in a museum; any evidence that he has failed to note has gone forever, and unless his record is scientifically complete he has defrauded science, and had better not have dug at all.

With this heavy responsibility he must be assured beforehand that he has a staff sufficient to do full justice to the work he would undertake. ${ }^{4}$ 
Freud had several high ranked international supporters who lobbied for him to be allowed to leave Austria. It may seem today as if there could be no other possible outcome than that Freud, a famous man, would be allowed to die in England from the cancer he had had for many years. But his sister Dolfi died in Theresienstadt; his other sisters Mitzi, Rosa and Pauli died in Treblinka, their relationship to a famous man no protection.

In 1938, while they waited for permission to enter England and permission to leave Austria, Freud's son Martin and daughter Anna were briefly arrested. Copies of Freud's Complete Works were confiscated and burned. Storm troopers came to Freud's house on 15 March and took away all the household money and contents of the safe. The Gestapo searched the house for political material. The contents of Freud's bank account were confiscated.

From his desk in England in November 1938, Freud wrote an essay called "A Word about Anti-Semitism". A copy of this essay, in cursive script, is part of an odd collection of material supplied in a pocket of a biography of Freud that I bought this year. Freud's handwriting is strongly sloped and the words are close together, making it almost impossible to read them. The author must have placed the document there to evoke the mood of 1938 , I decided. I do not imagine that I would ever be able to translate Freud's mood at this time, even if I could read the words. 


\section{Walter Benjamin's dream:}

... I saw myself in Goethe's study. It bore no resemblance to the one in Weimar. Above all, it was very small and had only one window. The side of the writing desk abutted on the wall opposite the window. Sitting and writing at it was the poet, in extreme old age. I was standing to one side when he broke off to give me a small vase, an urn from antiquity, as a present. I turned it between my hands. An immense heat filled the room. Goethe rose to his feet and accompanied me to an adjoining chamber, where a table was set for my relatives. It seemed prepared, however, for many more than their number. Doubtless there were places for my ancestors, too. At the end, on the right, I sat down beside Goethe. When the meal was over, he rose with difficulty and by gesturing I sought leave to support him. Touching his elbow, I began to weep with emotion. ${ }^{5}$ 


\section{A letter from Sigmund Freud to a friend:}

When, finally, on the afternoon of our arrival, I stood on the Acropolis and cast my eyes around upon the landscape, a surprising thought suddenly entered my mind: "So all this really does exist, just as we learned at school ..."

It must be that a sense of guilt was attached to the satisfaction in having gone such a long way: there was something about it that was wrong, that from earliest times had been forbidden. It was something to do with a child's criticism of his father. . It seems as though the essence of success was to have got further than one's father, and as though to excel one's father was still something forbidden ...

In our particular case, the very theme of Athens and the Acropolis in itself contained evidence of the son's superiority. Our father had been in business, he had no secondary education, and Athens could not have meant much to him. Thus what interfered with our enjoyment of the journey to Athens was a feeling of 'filial piety'. ${ }^{6}$ 
Orpheus, son of Apollo, was the most famous musician the world has ever known. When he played his lyre animals crowded round, lions lay tame at his feet, mountains would move towards the sound and trees would bend and pull up their roots to hear his music.

When he lost his wife, Eurydice, his songs became so sad that they broke the heart of anyone who heard them. He mourned alone on a mountain until one day the sound of Orpheus's lyre was gone and was never heard again. Some said the gods, unable to bear his lamentation, struck him with lightning...

Orpheus's lyre floated down a river and out into the sea, playing all the while. Eventually it washed up on the shores of the island of Lesbos, where it lay neglected, overgrown with vines and buried under leaves.

The winds of the island are known for their melodies, and nightingales sing more sweetly there than anywhere else. No bird sang more sweetly than Sappho. 
$L^{L P 67^{7}}$

]

and this

[

ruinous god

I swear did not love [

but now because [

and the reason neither

nothing much

[ 


\section{Arthur S. Way:}

The fame of Sappho, as the greatest poetess of all time, rests mainly on tradition, which for us moderns is confirmed by one complete poem, two incomplete ones, and over 170 fragments, one consisting of six lines, ten of four, seven of three, twenty seven of two, and the rest of not more than one line, sometimes of only one word. No other poet inherits such a great fame on so slight a foundation. Yet none is, by universal consent, more incontestably pre-eminent in his sphere. ${ }^{8}$ 


\section{Mysteries and speculations}

1. Sappho lived on the island of Lesbos in the sixth century B.C.E.

2. 'She' may not have been a single person; perhaps she was a school?

3. Her name was not pronounced 'Saffo'. It would probably have sounded more like 'Ppppsappoppo'. Speculative performances of her name, emphasising movements of lips, are to be found on YouTube.

4. Her poems were composed to be sung to the lyre. Except for what remains in translations of her words, all her music is lost.

5. The lyrics were sung in Aeolic Greek, a vernacular dialect which has now disappeared.

6. No one really knows the context in which these lyrics were sung.

7. There was writing in Greek in the sixth century B.C.E., but Sappho's poems were not written down until perhaps 300 years after she died.

8. On papyrus, text is written in columns, without word division, punctuation or lineation.

9. She was said to have made enough lyrics to fill nine books. The first book had 1,320 lines. Of the nine books of lyrics that Sappho is said to have composed, which might have amounted to about 10,000 words, one poem has survived complete. All the rest are fragments.

10. Oxyrhynchus, the place in Egypt where, in the late nineteenth and early twentieth centuries, Bernard Grenfell and Arthur Hunt of Queen's College Oxford found fragments of papyrus on which were written pieces of words or whole words thought to be recorded words of Sappho, has now been largely submerged by an irrigation project. 


\section{Three re-constructions}

1. In the early 2000s Michael Gronewald and Robert Daniel, working in the archives of Cologne University, found a document dated to the third century B.C.E. and used as part of a mummy's covering, or cartonnage. This fragment recorded quotations from three of Sappho's poems. Gronewald and Daniel described this discovery in a German papyrology journal in 2004.

2. One of these quotations, when put together with a fragment found in Oxyrhynchus in 1922 , made poem 58 , a bittersweet reflection on ageing.

3. Martin West published the new poem in the original Greek and in English translation in the Times Literary Supplement on 24 June $2005,{ }^{9}$ along with a short reflection about the youth of each year's new undergraduates. 
After a day of reading Sappho, I am on the beach, compelled to stare into the fire as it sinks below the horizon. The tip of every wave is shiny metal; all of us, strangers, neighbours and lovers, turn to each other and offer blessings; all of us knowing our part in this and no one awkward or reluctant. This moment is so completely Greek that I hurry home to find it in the poems:

I am looking for a phrase -

The background of choice for gold-sandaled

girls with purple handcloths, the source

of warm scented winds coming in from the sea and apple blossom petals on the ground -

A particular light on the last apple, so high on the tree that the pickers pretend they haven't seen it. The reason girls fill their laps with violets It is the source of the roundness of a round dance of girls, it will create a longing for clear keen song, gold cups and ankle bracelets, it will remind you of hot black earth It will have a hint of deference but no covering of the face with the hand It is your reward for the ritual gift of a white goat.

I do not find this prize -

I find instead, brightness that strikes the eye, I find the universal measurement of time from her time until there is no time -

I find the gift of light -

But never the sun dying for the day 
Yahrzeit is the Jewish name for commemorating the death of a parent or close relative at the time of year when the person died. Yahrzeit is marked at home by lighting a candle which burns all day. Some fast on this day, some abstain from eating meat or drinking wine. Some visit the grave of the dead person. The custom of commemorating the death of one's parents at the time of year when they died can be traced back to the time of the Second Temple (approximately 520 B.C.E.-70 C.E.).

Special candles are available but any candle that will burn for twenty-four hours can be used. Some families, concerned about the safety of an open flame which burns for twentyfour hours, use a special yahrzeit lamp. There are no special prayers or blessings that must be recited when lighting a yahrzeit candle, but often, at this time, people will spend time in introspection or share memories of the dead person.

In English, the word can also be spelled 'yartzeit', 'yortzeit', or 'jahrzeit'. 


\section{The poem about the candle}

The purchase of a yartzeit candle in the presence of tradition and an absence of belief occupies him. The placing of the candle in a cheap glass cup on the kitchen bench occupies him. The interest of a third-century scholar named Athenaios in the possible distinction between a whore and a courtesan occupies him.

Ignoring the candle, chopping vegetables and pouring milk occupy him.

The repeated holding of the cheap glass cup tilted towards his face and the striking of the match occupy him. The time it will take for the candle to burn occupies him. The aura of the brother; the peculiar way he could fold his legs occupies him. This form, its fire, the dim dim light 
In one sense the poem about the candle belongs to Glenn Kurtz, who happened to be reading If Not, Winter, Anne Carson's translation of Sappho, at the time of year when his brother had died. Glenn Kurtz is the man who bought the yahrzeit candle, wondered if lighting it would have any meaning which was real to him, and worried about how to remember his brother in a way that was in some way true to the man his brother was. Kurtz wrote about these things in an essay in the Southwest Review in 2010. ${ }^{10}$

Glenn Kurtz is an established writer. He lives in a country where a living can be earned writing and talking about books. His essay is six pages long. In this space he patiently unfolds and dissects the story of reading the book and the story of living through the month leading up to the lighting of the candle. He examines these experiences in a cool morning light. Then he tilts the two things towards each other and looks at whether that movement changes the way light falls on each. This last action caused me to write the poems.

All the way through the essay I had a strong sense of the man as well as the author. I could feel him taking pieces of the two experiences and rubbing them between his thumb and his first two fingers, as I might feel a piece of fabric to learn its qualities. I could hear his voice as he speaks to himself and to his readers about what he is thinking. I noticed how strict he was with himself, alert for any backsliding to some cheap and easy version of grief that might infringe the rights of the dead. As he brings his arguments together, he says that he has learned something new about mourning from juxtaposing his own loss of a brother with Anne Carson's translation and its 'aesthetic of loss', but I found that I could not put my finger on what it was that he had learned.

I read his essay several more times, looking for the places in the text where something seems to change. I started marking those places with a pink highlighter pen. After a while I found that I had fallen into a sort of trance where most words passed in a blur but a few words seemed to jump out at me. I stopped marking these jumping words with the pink pen and started writing them down. After four or five phrases I looked at what I had written. I liked the particularity of the man's actions and I liked the spaces it left.

Almost every word in the poem about the candle comes from Kurtz's article. I changed 'cereal' to 'milk', which I thought more comforting. I also translated the American 'kitchen counter' to the New Zealand 'kitchen bench' and paraphrased a comment about religious beliefs. Rather more significantly, I added the idea of deliberate ignoring which takes up the whole first stanza of the poem. Re-reading his article a year after writing the poem, it is clear that I re-wrote his story to make this first stanza. I am not sure whether I used 'occupies him' in that repeated way because I didn't believe him that the candle sat inert for a week while he lived around it, or because I needed a verb. The second stanza of the poem about the candle fits more closely with the sentiment Kurtz describes. 


\section{The muttering poem}

It is the death day and so

the light returns to view the soul

the dead we have lost but

this ritual has little to

do with his soul - if

I believed the flame the persistence

I could rest

The truth is something very different -

I do not hear a presence

yet the image flickers.

This is a dim dim light

Scholarship also tricks us -

Nothing fills the silence

in this broken aching form.

The candle flickers - I feel

a different reanimation from

damaged papyrus and open space

all faithful

but not the one who lived.

This explains the gravity the tenderness

This alone on an otherwise blank page 
The muttering poem had a different genesis. At the same time as I was reading Glenn Kurtz's article, I was also 'reading' Jonathan Safran Foer's Tree of Codes, which is an erasure and die-cut of The Street of Crocodiles, by Bruno Schulz. Tree of Codes contains words, punctuation marks, and the usual white spaces a reader would expect in an erasure. It also contains deep rectangular holes of various sizes. These take the reader down to lower levels of the book.

'[The Street of Crocodiles] is a book I've always loved,' Safran Foer said in an interview with Heather Wagner from Vanity Fair. 'Some things you love passively, some you love actively. In this case, I felt the compulsion to do something with it.. ${ }^{11}$

I imagine that early on, Safran Foer would have marked with a pencil or a highlighter the sections he wanted to keep, the parts he wanted whited out and the parts he wanted cut out. But, at a certain point, Safran Foer, or his assistant, must have cut into the pages with a knife. And, even worse, he would surely have needed to cut several copies before he found exactly the right sections for the die-cut. I am shocked by Safran Foer's physical surgery on a loved book.

'Whose book is this? Is it your book? Or is it Bruno Schulz's book? You are using his words,' Wagner asks.

Safran Foer answers:

This book is mine. His book is a masterpiece, this was my experiment. My story has nothing to do with his story. There's the sense that every book every written is like this, if you use the dictionary as a starting point. This is a more limited palette, but it's the same idea.

Placing Schulz's book and Safran Foer's book side by side one morning, I investigated Safran Foer's story, starting with his choice of words. I had a theory. I thought perhaps Safran Foer had the story of Schulz's death, and the Holocaust itself, so firmly in his mind that he might have chosen to retain only words soaked in this darkness. I am still not sure whether this is true or not, but I did find out that Safran Foer's new sentence structures always use words and punctuation marks from Schulz's sentences in the order of the original. The new 'sentences' of text may have large or small white spaces inside them. The new structures, with their white spaces, sit alongside and in-between the physical holes made by the die cut process. The content is, and at the same time is not, Schulz's content.

Intrigued by this, I experimented with choosing items from Kurtz's essay using the same rule: anything, from anywhere, as long as it is in the same order as in the original text. The muttering poem is the result. 
At some point I stopped caring about the scholarly search for Kurtz's meaning and the method used by Safran Foer and started caring about the life of the new poems. I see these as my poems now, alive in the world, but having strong genetic links to Kurtz's essay. I do not know whether these poems succeed in locating what Glenn Kurtz learned from juxtaposing fragments of Sappho's poetry with his own grief and the general human process of mourning. I expect not. 
In the summer of 2008, amongst a group of strangers roughly brought together, in a town that was part of New Zealand's gold-mining past, I met a man I had heard was a poet. A fog of awkwardness came up from the valleys and hung low over the table, causing the sound of our sips and swallows of tea to be magnified, as all sounds are in fog.

Pines from the Northern hemisphere tolerate cold better than some native shrubs and plants, said one of the farmers at the table, and if they are not stopped they will eventually replace the all the natives in the hill country. First you see a line of them, or maybe a plantation on a hillside. Then, if you look, you see a few in the paddocks nearby, maybe in clumps of three or four. If you stand still and look even further away, you can sometimes see a few moving, little Christmas trees, out by themselves, miles away from the original plantation. Like rabbits, he said. And then the conversation turned to the difficulty of killing rabbits in sufficient numbers to be useful.

Under cover of this conversation, I looked at the poet and asked him what had brought him to writing. He paused for a moment, perhaps considering how to answer this personal question asked by someone he had never met before. There was a time in his life which required everything of him, he said. He gave me sad details which I will not share here. Late at night, by the fire, after days that each lasted a hundred years, he began to write poems. It was the only thing which kept him sane, he said.

After this, he looked at me and asked what brought me to writing. I told him that even though I had had an easy life, my reason was the same.

Later he wrote to me, sending me a book of his poems. I like poems that come from the heart, he said, in his letter. Some of our well-known poets write cold, abrupt, precise verse that I find hard to understand. I think those poems come from the brain.

He had lived his life in the high country, he said, in a way that has now almost disappeared. It was hard to explain. 
She used to ask me, What is it like up there? This is what I told her, he said:

First we hear the horses' hooves as they strike granite or a running down of gravel set off by the horse. Sometimes nothing when our horses walk over a patch of moss.

We hear the wind, and feel it tugging at our faces. We may hear nothing but that wind for three days and nights. There are no birds.

We hear each other's horses and each other's dogs, but never each other's voices. Not until the day is finished and we are sitting together by the fire in a hut somewhere, and even then there is no need to say much.

What we do hear is the sound of mountains doing whatever mountains do. I suppose you could think of it as a form of gravity, a weight that we all feel under us. It would be stupid to say that it bears us any ill will, although it may be that we would die there on any day; as stupid as it would be to say that we belong there. We are ants if you like, creeping up over a large animal. It is always huge and we are always ants. 
He told me he had a disease of the eyes which meant that he could no longer read, and that although it might seem that this would be a terrible thing, in fact it was something which had liberated him from all sorts of obligations.

At first he had noticed that straight lines, such as the edge of a table or top of a fence, looked wavy or crooked. Man-made objects looked further away or smaller than usual. After that he noticed that he could no longer see faces clearly. Finally one day a dark spot arrived in his central vision and had never shifted since that day.

For reasons which I think should remain his own, he had been moved to write many poems in his life. At home I read all the books of his poems. I saw his first love, a woman with dark hair, who left him one day in a way for which he was not to blame. I saw tiny men and their animals moving across the land for reasons which could not be deciphered. I saw the sun rising and setting. And I saw a dark spot which covered almost everything. 
Now again, grasses wave

mule trains

old tin huts

the southern cross

hanging just above the pines

night winds

frosted star

fragrance tussock ferns

wild swans, the cottage

lilac flowers in her horse's mane

but everything

sweeter than that

white faced cattle, that distant camp

signs, yes I see the sunset

flaming like a bushfire

the saddle horse is standing silent form 


\section{Keas call for me}

as if searching for something that's missing

But I have not been back

her gentle heart, that old blue hill

a sapling willow that we planted

before the snows came down

splash of scarlet berries

thunder of night rivers

but everything sweeter than that 


\section{I'm not sure what to call what I have done}

When I describe it, other poets look at me askance.

I chose the latest collection by a poet who has written hundreds of poems but has never hit the big time.

I read all the poems in his latest collection and I wrote down only the beautiful words. If it was music it might be called sampling.

As proxies for philosophers and people of all religions, I asked four other people to read all the poems in the latest collection by the poet who has written hundreds of poems and write down all the most beautiful words.

Any word or phrase chosen by three or more of us was saved.

As the person with the idea I claimed the right to arrange these beautiful words into a poem, leaving spaces

to stand in for all the ordinary bits.

For a short time I was content with my new poem and undisturbed by the thought of the beautiful words, and the words chosen as beautiful by a minority, mixing with all the ordinary words, in the original poems.

But last week, seeing that there was a full moon and many stars, which I knew the moon would soon obscure, I took the latest collection by the poet who had written hundreds of poems but never hit the big time and I set fire to it on the beach.

Soon I will make a new poem from the few words that survived the flames a poem based on weight alone. 
As far as I can see, choosing the most beautiful words from another poet's book and making them into two new poems does not have a precise literary name. It is perhaps 'homage', although what I have done might be thought by some to lack respect. My own intent was respect-full, but also curious.

I have produced two poems from a book of poems. ${ }^{12}$ These two poems are a contraction of the original book of poems, in some way representing them all. I have given the new poems titles which bear no relation to the names of any of the original poems or the book they came from. I have changed genre from the style of ballads intended to be declaimed in pubs to lyric poetry full of spaces; a form most suited to reading on the page. The words I have chosen are clear traces of the history of the poems and also of the life the poet lived in the hills, a way of life which has nearly vanished.

My method and purpose for choosing the most beautiful words from another poet's work and making them into a new poem come close to the musical and literary practice of making an edit. However the fact that I have changed genre and produced a new title for each of the new poems suggests that a significant measure of re-imagining has gone on. This does not fit within the usual range of activities of an editor.

I have not discussed all this with the original author so I don't know how he would feel about what I have done. Also, if I began this conversation with him, he might notice a couple of unfamiliar lines and I would have to confess that two of the best lines come from other poets whose work I happened to be reading at the time.

I understand that this latter action is not at all uncommon, especially among poets, because every writer is also a reader and of course the words that make the most impact are likely to be remembered. Some writers say that they are surprised to find these buried treasures in their poems, insisting that when this happens it is an accident caused by the activities of the subconscious.

In my case it was completely deliberate. I even looked up the lines to make sure that I was keeping the power of the original. I deduce from this that I do not suffer from anxiety of influence brought on by the overwhelming desire to write something altogether new and significant. One of the first people who saw the new poems said that the last line of "Now again, grasses wave" had something of the feel of Sappho about it. Yes, I said. How marvellous that when a person reads a poem she brings with her the memory of every other poem she has read! I need that in a reader.

I am sorry that other readers have not met the poet whose words I used as an instrument. If they had they might understand when I say that in some strange way the new poems invent and recount his entire life story. 
At first I thought this resulted from a piece of communication from him to me and from me to him in an unnamed and mystical eleventh dimension; this process rather more reciprocal than traditional psychoanalysis. Later I realised that in choosing the poet's most beautiful words I had also chosen his packhorses, ready any day to cross any river. 


\section{Arthur S. Way:}

Sappho is known to the general reader only by an ode and a half: but there are extant besides over 170 fragments, most of them very short, consisting in some cases of but a single word. Yet of these many, indeed most, are very tantalizing in their suggestiveness; and our poets, notably Swinburne, have expanded some into fairly long poems. The present translator has attempted no such flights. His endeavour has been, not the presumptuous one of restoring Sappho's Odes, but that of presenting some of her thoughts, grouped together, with just sufficient connective matter of his own to produce an intelligible sequence, in the hope of thus making the fragments as interesting to the general reader as they have been for the scholar-for whose scandalised eyes this version is, I need scarcely say, not intended. ${ }^{13}$ 
Ras_G:

Secondhand Sureshots with me, my man J Rocc, Daedelus, and my man Nobody. They all my mans. It's a documentary put together by my man Frosty, lab rat cats over at Dublab. He gave us all 5 bucks, took us to Out of the Closet, made us buy 5 records, and he kept the records, it's not like we got to actually hold the records down and make beats on our own time, nah. They came to our house with the cameras, brought the records with them and recorded us hearing the records for the first time. I can't wait till it come out, when you see it peep it out. ${ }^{14}$ 


\section{Thomas Brett:}

The idea behind the documentary DVD Secondhand Sureshots (Dublab Collective 2010) was to invite four DJ/Producers to each build a new track based solely on their vinyl finds in California thrift shops. The DJs Daedalus, Nobody, Ras G, and J. Rocc would each have five dollars to buy any five records they could find (and which could not be previewed at the store). The rules for assembling tracks were equally strict. A track can only be built out of sounds sampled from the found vinyl, and only cuts and effects (reverb, etc.) can be added to the track. No drum machine beats, other instrumental sounds, or extra samples can be used in the compositional process ...

Ras G refers to records as feminine presences, speaking of "taking her home." When asked how he cleans his records, Ras says that no, no, dust is good: the audible crackling it creates functions as "seasoning." Then he finds an LP of traditional Japanese koto music and says: "this guy is about to get mo-lested . . musically."

Chopping, as J. Rocc puts it, involves "editing the sample to the parts I would want to use." Rocc and Ras use an Akai MPC to do their sampling and chopping, Daedalus uses Pro Tools, and Nobody does his work on a keyboard. But regardless of their working methods, each DJ aims to make something new and personal out of something old and discarded because it was thought to have lost its value. As Daedalus notes: "The game isn't to make it unrecognizable; the game is to make it your own." 15 
Intertextuality

all previous individual sensory experiences +

all previous emotions +

'author' 'author's' new 'text'

all previous spiritual experiences +

all cultural references and preferences+

all previous textual and artistic evocations of these 


\section{Thomas Brett:}

After the tracks are finished they're mastered and pressed to vinyl and the DJs meet to listen to one another's work and share their vinyl finds. Meanwhile, a new piece of composite record cover art has been rendered from shards of the twenty LPs used to make the new tracks. Assembled onto one disc in this new composite record sleeve, the work of the DJs now forms yet one more piece of vinyl destined for...you guessed it, the thrift shop. And so ... we watch Daedalus, Nobody, Ras G and J. Rocc return to the thrift stores and secretly drop off copies of their new creations into the dusty bins. ${ }^{16}$ 
Everyone knows that when a culture is in decline, or has been defeated by a greater power, its discarded artifacts float by themselves in the world, unguarded. Objects floating like this are available to be 'discovered' by others, sorted, uplifted, sold and re-sold until perhaps a select few reach a museum.

Within our own culture, cast-away objects pile up on the pavement outside houses, 'op' shops, on websites and in the tip. These might be objects valued by a previous generation, but almost worthless now, like my grandmother's crystal, or objects that never had much value to begin with, like cheap appliances and bedding found in skip bins at the end of the year when international students leave New Zealand to return home. Whatever you think about this, it is familiar.

But this final process of the Secondhand Sureshots project, where a new object made from old is placed back in the unguarded space of a thrift shop; this keeps me awake at night.

Lying in the dark, thinking of new but reconstructed objects in unguarded places, I find myself picturing a group of dark-haired young people in blue shirts, building a rough new wooden fort next to the memorial to the Warsaw ghetto uprising. As the sun goes down, they build a fire and most of them eat, dance and sing songs. A few of the young men and women carry weapons. They guard the fort from watchtowers.

The people I see in the night are young Jews, born everywhere, returning to Poland because they have been invited by a Polish activist who will soon be assassinated by other Poles. The return says that Jews and Poles can't do without each other after all.

All of this is part of an artwork by Israeli-born artist Yael Bartana, called And Europe Will Be Stunned. ${ }^{17}$ Seeing this collection of three films rendered me speechless. 
Later I phoned the curator of the exhibition and asked her why the Govett Brewtser gallery had chosen to display Bartana's work and how the public had reacted to it. She told me of her longstanding interest in making exhibitions she described as politically engaged, and the commitment of the Gallery to experimental and challenging work. However her interest did not extend to finding out the meaning visitors made of the exhibition. Politely, she gave me the phone number of the marketing person for the gallery. I did not phone this person. I did not want to know how many people had been in the gallery on any particular day and how they heard of the gallery. I wanted to know what people made of Bartana's actions, appearing as they did, in a provincial city in New Zealand in 2012.

I want to go again to this exhibition, this time with a focus group. Seven is a good number for a focus group. 
Intertextuality

all previous individual sensory experiences +

all previous emotions +

'reader' meanings of new 'text'

all previous spiritual experiences +

all cultural references and preferences +

all previous textual and artistic evocations of these 
In physics there were once thought to be three dimensions: height, width and depth. A rigid body moving in these three dimensions of space was thought to have exactly six degrees of freedom. Using permutations of these dimensions people specified the de-formed position and new orientation of the body in relation to its initial position.

When Elvis Presley sang Blue Moon of Kentucky, written by Bill Monroe in 1946, in the Sun recording studio in 1954 or 55, the original waltz time changed to 4/4 time, the countrystyle accompaniment changed to electric guitars and the acoustics were given a particular boom. The anatomy of the throat and vocal cords of the singer gave a particular sound. This sound gave a particular feeling to people hearing his voice. Elvis's intentions on that day, as he stood on the street outside the studio, would be hard to unearth. The song Elvis sang, which was the same as the original in only melody and words, is referred to as a version of Bill Monroe's song.

At that time the tradition was that people often made their own versions of songs they liked, and gave credit to the original songwriter. This credit took the form of written acknowledgement and money. Because of the degree of difference in tone between Elvis's Blue Moon of Kentucky and the original, much gentler song, which could be compared with the difference between casual sex and lifetime love, some people thought that Bill Monroe would be offended by the Sun Sessions version. But Monroe sent Elvis a letter of thanks. This may have been inspired by the money he received from every purchase of Elvis Presley's version on vinyl. People may have liked Elvis's version better than Monroe's, but Monroe still owned the rigid body of the song.

A non-rigid or deformable body may be thought of as a collection of many minute particles or fragments with an infinite number of degrees of freedom. In practice a deformable body is often thought of as a rigid body or even a particle in order to simplify the analysis. But how many dimensions are there? As many as it takes to make a theory work.

Music has no equivalent to the quotation marks used in writing. In 1961 another musician made what he called a 'collage' of Blue Suede Shoes, a song which Elvis made into a hit, but was written by Carl Perkins. I have not heard this 'collage' but I have heard that when you listen to it, you hear it in relation to Elvis's version. 


\section{It's only a dead tree}

Some friends who live in the same street as me are having trouble with a huge, mostly dead macrocarpa which has its roots in their neighbour's place but hangs over their house like the arm of a crane, creaking and threatening to come through their roof each time there is a storm.

Cupressus macrocarpa. Naturalized New Zealander. Grows larger here than it does in other places. Can grow to 40 meters high. Trunks of 3 meters diameter have been documented.

The problem is that the macrocarpa tree, along with several absurdly tall pines and a tiny roughcast bach from the 1950s, all belong to a woman who lives in New York. She is adamant that nothing at her Raumati property can be changed. The macrocarpa tree cannot be cut down. It cannot even be trimmed. Not by an arborist. Not at my friends' expense. And not because it might fall and hurt them or break their house in two. My friends are worried and exasperated. They have sent many emails to the woman in New York. They have had lengthy discussions with their insurance company, in advance of a likely catastrophe, and now the woman in New York has stopped answering their emails.

They are stumped. I am stunned too. They are such polite and reasonable people that I cannot imagine them failing to negotiate a resolution to this problem. Then I think about the woman in New York and I ask if they know why she is behaving like this about a dead tree. They say they do not understand it either. After all, she only comes to the bach once a year for one week. Why does it all matter so much?

Then comes this extra information, rounding out what they know of her. Her mother came here after ... they said. Somehow, from the pauses, I know they mean that the woman in New York is Jewish and that her mother was a survivor of the Holocaust. 
From my imagination and from the accounts of other survivors who used to spend happy summers at Raumati in the 1950s and 60s I guess that out here the mother of the woman in New York and all her refugee friends used to sunbathe and relax with people who, like them, did not have family to visit, and like them, needed all the sun they could get. Maybe out here, at the bach, with the windows open and the smell of pine trees coming into the bedrooms, that little girl also had a rest from everything.

None of this helps with the tree situation.

A friend who works in the museum industry told me that recently he re-visited a museum he helped establish about ten years ago and found that absolutely nothing had changed from the day the museum opened. I am not expecting many changes to the tree situation either. 
LP67 $^{18}$

]nd this overhan[

]tructive spirit[

]truly did not lik[

]and now because[

]the cause neither[

]nothing much[ 
It is Prague, after World War I. A boy called Josef is led to the panorama by his grandmother who loves this outing as much as he does. She pays for them to enter. They climb up on stools and place their eyes to a set of eye holes, a little like binoculars. They see a sequence of pictures on a certain topic. Each time a picture arrives there is a flash of light and they see an image.

It doesn't matter that you must sit a little awkwardly to reach from the stool to the metal eyepiece and that you must sit rigid in this posture if you want to see the images. It doesn't matter that your breath condenses on the metal of the eyepiece, drips onto your face and runs down your cheeks like tears unless you lick each drop as it passes your mouth, which the grandmother says is unhygienic.

It doesn't matter when you arrive, because although the pictures are in a certain order the panorama machine shows the sequence again and again; you could stay all day if you wanted. It doesn't matter where you start. It doesn't matter where you stop. No one will ask you what you saw or what it meant. You watch, you do what you like with your thoughts and then you go home. Next week there will be a different show. 


\section{Methodology:}

- Observation of contemporary everyday behaviour or rudimentary behaviour;

- re-construction of the historical phases of the cultural evolution of the behaviour under investigation;

- experimental production of change from rudimentary to higher forms of behaviour;

- observation of actual development in naturally occurring behaviour. 
In 1896, Egypt was occupied by the British although still part of the Ottoman Empire. British interests had owned the Suez Canal since 1875, and Britain had a strong influence on the politics and financial structures of Egypt. Bernard Grenfell and Arthur Hunt, from Queens College Oxford, went to Egypt with funding from the Egypt Exploration Fund, looking for pieces of papyrus.

Grenfell and Hunt settled on a small town 120 miles south of Cairo called Oxyrhynchus, meaning 'sharp nosed [fish]'. Part of the same site is now a village called, in modern Egyptian Arabic, el Bahnasa. On the outskirts of town was a group of low mounds. Almost as soon as they began to dig, Grenfell and Hunt realised it was the rubbish dump of a once thriving town dating from the period of Hellenistic Egypt. Grenfell and Hunt supervised hundreds of Egyptian workers excavating the rubbish mounds. For months they piled tiny scraps of torn papyrus into reed baskets, sifted and deciphered them, before packing them up into Huntley \& Palmers biscuit tins and sending them back to Oxford. 
Grenfell and Hunt's excavations continued into the twentieth century, stopping only for World War I, until Grenfell died in 1926. Hunt then continued the work until he died in 1934. Most of the fragments are records of everyday life: bills and receipts, IOUs, invitations, inventories, tickets, laundry lists. But one page seemed to record some of the sayings of Jesus and another was attributed to Euclid. Grenfell and Hunt found another tiny scrap, dating from the third (or sixth) century C.E., in 1897. This was a copy of a poem by Sappho, a new poem previously unknown, and now referred to as Fragment 5: "To the Nereids."

In the end there were crates and crates of such fragments, and the process of dealing with them goes on to this day. The Egypt Exploration Society began, slowly, to edit and publish the finds. Despite having reached their sixty-sixth volume in the series, the findings are still being published, and the Ashmolean Museum at Oxford still holds crates of fragments in its basement.

In 2011 the University of Oxford invited ordinary people to help transcribe fragments of papyrus, using an online transcription tool. ${ }^{19}$ No prior knowledge of Greek is required, they say, however it has been necessary to provide a chart which shows combinations of letters which are possible and not possible in Greek and also a list of reasons why Greek text may include combinations of letters which are not possible in Greek. Names imported from Hebrew, for example.

I may be wrong but I guess this invitation to the public means that the words on all the big pieces of papyrus have already been transcribed, forming the basis of many academic careers, and that the volume of tiny fragments, as yet untranscribed, is a bit of a nuisance. Although held at Oxford University, the papyri remain the property of The Egypt Exploration Society. 
Huntley \& Palmers are proud of the history of their biscuit tins, especially the square 5lb and $10 \mathrm{lb}$. . . tins which could be used as storage for virtually any sort of cargo' ${ }^{20} \mathrm{His}$ Royal Highness Prince Henry of Battenberg, who was married to one of Victoria's daughters, died on 20 January 1896 during the Fourth Anglo-Ashanti War but he was able to be buried with proper ceremony only three weeks later in St Mildred's church on the Isle of Wight thanks to the traditional naval practice of carrying home the body of someone important submerged in rum.

In the case of Horatio Nelson, who died in 1805, the only option had been to fold him into a barrel and cover him with rum for his journey home, but by the time Prince Henry died, he was able to be carried home lying down in a tank made out of Huntley \& Palmers biscuit tins. The metal tank may also have offered better protection from sailors who were known to tap a barrel and drink the rum even when there was a body inside. 
Biscuit tins in the Sudan. On 2 September 1898 the British defeated Mohammed Ahmad, who believed that he was the Messiah, at the battle of Omdurman. This battle was said to be necessary in order to maintain British control over Egypt and the Suez Canal. Some captured Sudanese swords had scabbards with metal bands cut from Huntley \& Palmers biscuit tins, with the firm's name clearly visible. 
And Bibles in Uganda. Bibles and prayer books for the natives were packed into biscuit tins to protect the books from white ants.

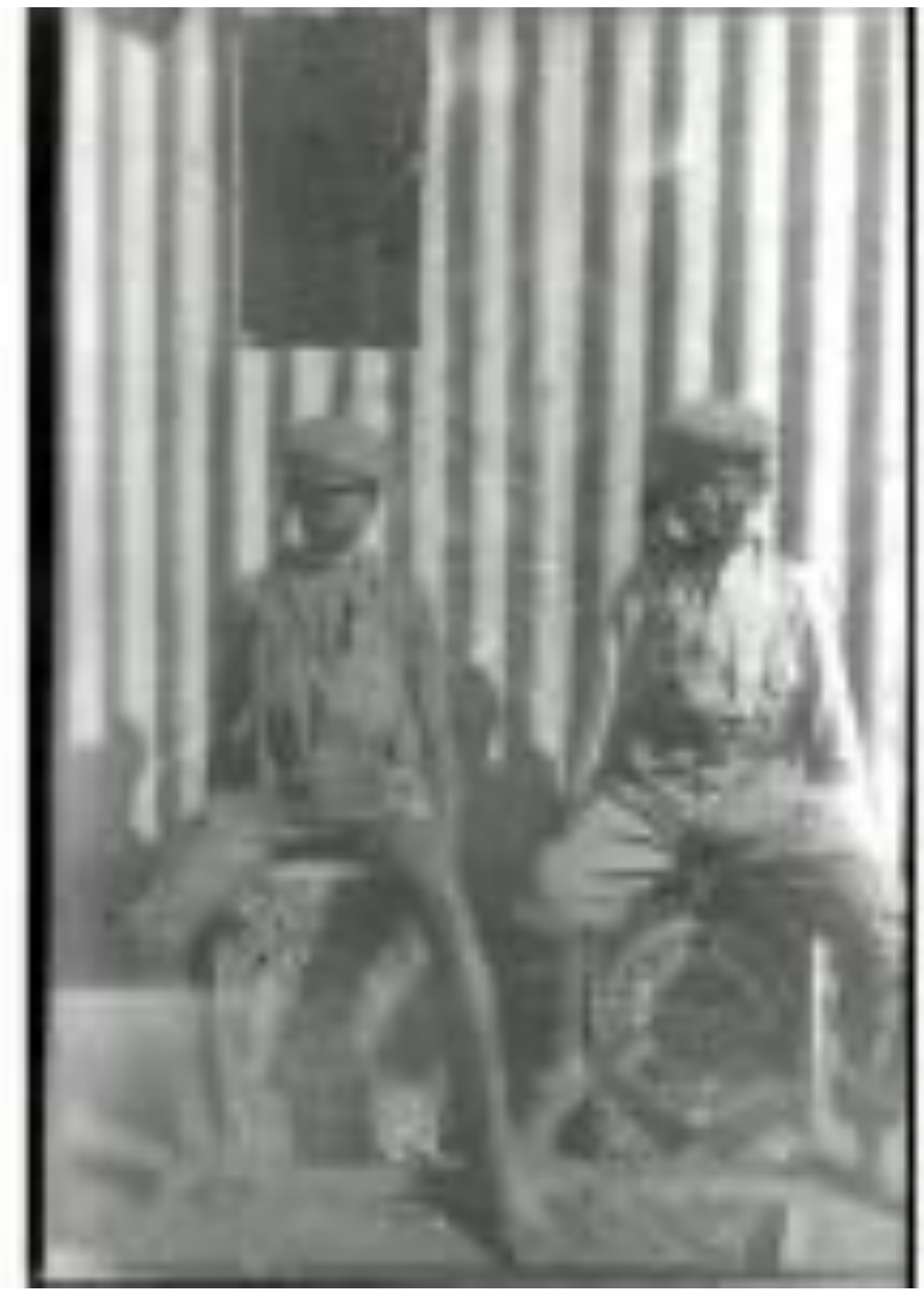

"African Boys, about 1903" 21 


\section{Sir Leonard Woolley:}

... the work of a big [archaeological] gang. . . is organised as follows:

All the men are directly under the orders of three trained and trusted Arab foremen . . . who come from far away in North Syria, whereas the workmen are recruited from the neighbourhood.

They are divided up into small parties consisting of a pick-man, a spade-man and three or four basket-men; of these the pick-man is selected for his experience and his superior intelligence - he is generally one who has been employed by us for a number of years, and is not so old as to have grown stupid nor too young to exercise authority; he uses an army entrenching tool (the best tool I know of for excavating in Iraq) and is the head of his little gang; since he does the actual cutting away of the soil it is he who discovers things, and it is up to him to see that he exposes them without damage. The second man, armed with a long-handled native spade, puts the loosened earth into the baskets, and if the pick man has missed anything the spademan ought to see it; the basket-men are either the older fools or the young recruits, and their job is purely mechanical - they simply have to carry the full baskets to the light railway, tip the earth into wagons and come back for more...

The moment a pick-man sees anything of possible interest . . . he has to report it to the nearest foreman, who, taking over the pick, satisfies himself as to what is really there, and either tells the man to carry on ... or calls up one of the staff. Then the archaeologist, who the moment before may have been writing notes in a different part of the field, has to take his turn with the pick, or more probably the knife, and may spend the next few hours crouched in the same hole, in the same uncomfortable attitude, engrossed in the cleaning, recording and safe removal of some particularly fragile object.

The difficulty is to combine this necessary work of detail with the supervising and recording of what is going on in all the other parts of the field $\ldots{ }^{22}$ 
Grenfell and Hunt's letter to The Times, 14 May 1906:

The evidence of documents found below the literary texts shows that the latter must have been thrown away in the fifth century; but the manuscripts themselves are chiefly of the second or third century ... It is doubtful whether continuous sheets of much length can be built up out of the innumerable fragments, which range in size from some lines to a few letters.

This is the more regrettable because the owner of the library was much interested in the Lyric poets. His collection included two or three manuscripts apparently of Sappho. ${ }^{23}$ 


\section{Sir Leonard Woolley:}

Supposing that a peasant somewhere or other unearths a marble statue or a gold ornament; he sells it, and it passes from hand to hand until from a dealer's shop it makes its way into a museum or a private collection. By this time nobody knows where it was found or how, it has been torn from its context and can be judged only as a thing in itself; its quality as a work of art does not suffer, but how about its historical value? Experts have to guess, from such knowledge as they already possess, to what country and age it belongs, and if they agree the statue or cup is assumed to illustrate further that particular known phase of art; very likely they will not agree, and it becomes a bone of contention for the learned, and a source of confusion for the layman. ${ }^{24}$ 


\section{Q: When was the golden age of thrifting records and why?}

A: Dublab director Bryan "Morpho" Younce:

For me it was the early to mid-nineties, when I first started getting serious about record shopping. I found a lot of great jazz and psych stuff in those days. People were still getting rid of their record collections because they all thought CDs were this great technology that was taking over for good.

A: Mark "Frosty" McNeill (Dublab DJ):

Today! Hidden treasures are always out there. Someone's garage is being boxed up and hauled down to the thrift store at this very moment. Who knows what's in the back of that station wagon? The Out of the Closet thrift store chain is especially awesome because they're all over town and the records are only a dollar each. ${ }^{25}$ 
9 February 2001: In a town called Drohobych in Ukraine, Benjamin Geissler, a German documentary film-maker, records the exact moment that Bruno Schulz's murals are found in a pantry off the kitchen of an apartment occupied by Nikolai Kaluzhni, a former Communist Party clerk, and his wife, Nadezhda.

Since World War II, others have searched for these murals, even searching in this same pantry, but until this day no one has noticed the shadows clearly visible under the painted surface of the walls in a place above the doorway. Encouraged by this, Geissler, his father, a camera crew and three Polish-Ukrainian art experts who have raced to the scene, push past the weeping Nadezhda into the pantry, looking past her bags of onions, strings of garlic and the shelves of rags and pots which signal poverty in any language. One of the experts starts applying a solvent to the paint on the wall while all the others watch. Outside the pantry, and outside the shot, the former Communist Party clerk is in bed, dying of cancer, and his wife lists her illnesses and burdens in a language which I assume is Ukrainian.

Schulz, known for his avant-garde writing and his visual art, painted these images in the winter of 1942 on what was then a child's bedroom wall in a house occupied by Felix Landau, a Gestapo officer. Landau was in charge of Jewish forced labour in Drohobych. At this time Landau kept a diary of his actions and feelings. Of an early morning execution on 12 July 1941, he wrote:

At 6 a.m., I am suddenly wakened from a deep sleep. Fall in line for an execution. Alright, I'll play the role of the executioner and after that the gravedigger. Why not? It is strange. A man who loves to fight has to shoot up defenceless people. 23 are supposed to be shot. Among them are the two women I already mentioned...

Strange, I am completely unmoved. No pity, nothing. That's the way it is and then it's all over... Valuables, watches and money are put into a pile. $^{26}$ 
In 2001, Dieter, one of Felix Landau's children, lives in Australia. Christian Geissler, the director's father, phones and speaks to Dieter's wife in English. He explains that he wants to ask Dieter about the paintings by Bruno Schulz. His wife, who has an Australian accent, says that Dieter would not want to talk about this. I find it somehow shocking to hear that Dieter Landau lives in Australia. I don't expect to hear these conversations, relayed across languages, from Australia, which is over here, not over there, and from people close to my own age.

Next we hear Christian Geissler asking Dieter, in German, if he remembers the paintings. He doesn't. He was too young. He was only three or four. The list continues. He hardly ever spent time inside the house. He definitely doesn't remember the paintings. Dieter then asks Geissler how old he is. Seventy-one says Geissler. Well, says Dieter, in that case you know how crazy things were back then. 
Agnieska Kijowska, a member of the Polish-Ukrainian expert group, wets cotton wool with clear liquid from a bottle and wipes yellow-beige paint from the walls of a tiny room. As she wipes, the colour red appears from underneath.

$$
\begin{aligned}
& \text { The festive red of sealing wax and } \\
& \text { calendar print, the red of coloured } \\
& \text { pencils and of enthusiasm, the } \\
& \text { amaranth of happy telegrams } \\
& \text { from far away. }{ }^{27}
\end{aligned}
$$

Amaranth usually refers to a type of grain. But amaranth can also be a purple colour or an imaginary flower that never fades. Here, in this passage, I like the idea of the imaginary and never fading flower best. Perhaps Schulz's intention is clearer in the original Polish? 
We hear the voice of an older man, Mr Wojciech, who is obviously close by. As more of the top layer of paint comes off, we hear a conversation between Kijowska and Wojciech. This particular version of their conversation is transcribed from the English subtitles of Geissler's film Finding Pictures. ${ }^{28}$

Mr Wojciech: Do we know where this picture ends? Somewhere here?

Ms Kijowska: I don't know - I don't think there are distinct segments. No, it seems to me that ... Maybe there next to the green ...

Mr Wojciech: There-

Ms Kijowska: Perhaps further down.

Mr Wojciech: It is enclosed by a rectangular composition.

Ms Kijowska: I don't think these figures have a background. - Yes . . .

Mr Wojciech: What's this? A mural or not? This uncovered surface shows nothing.

Ms Kijowska: Only blue showing through. Is that it?

Mr Wojciech: The entire height of the composition?

Ms Kijowska: It's probably just a blue wall.

Mr Wojciech: I see. The height . . . about one meter.

Ms Kijowska: Ahhh (a rising inflection that you might use with a child)... Here's a little face.

Mr Wojciech: It's sky blue, right? We all agree. And on the sky blue ... (loud: a pronouncement) There's a scene that's about $80 \mathrm{~cm}$ wide.

A man's face appears from under the paint. He is wearing a blue helmet.

Mr Wojciech: An asymmetrical composition ... (same loud tone)

Ms Kijowska: Mr Wojciech . . . here's a little face.

Mr Wojciech: Wonderful! Oh my God! It's typical. Oh my God! Isn't it? It's typical. It's reminiscent of his self-portraits. Oh my God!

Ms Kijowska laughs

Mr Wojciech: This is it!

Ms Kijowska: How true.

Mr Wojciech sighs 
Mr Wojciech: Director, essentially this proves that it was Schulz.

He laughs 
Grim fairy tales: The facts of what happened after that conversation are contested. The meaning of the events is even more contested. This version, part of a much larger article written by Celestine Bohlen, appeared in the New York Times on 20 June 2001, under the headline: Artwork by Holocaust Victim Is Focus of Dispute.

A bitter international scandal has erupted in a city in Ukraine, about 30 miles from the Polish border, where last month workers from Yad Vashem, Israel's main Holocaust museum, chiselled five fragments from a newly discovered series of wall paintings. They are the last known work of Bruno Schulz, a Polish Jewish writer, artist and Holocaust victim.

With that single act, whose legality is disputed, Yad Vashem, the most august memorial to Jewish victims of Nazi slaughter, has unleashed a rumble of protests through a part of Europe that still feels battered and bruised by a vicious and violent century.

The Schulz murals, illustrations of Grimm fairy tales that decorated the nursery of a Gestapo officer's son, have been caught in the throes of that history. According to Yad Vashem, the fragments in its possession, which depict a princess, a horse-drawn carriage and several shadowy figures, including two dwarfs, are now being restored. Plans call for them to be put on display at Yad Vashem's new historical museum in Jerusalem, which is to open in $2004 .^{29}$ 
The removal of the murals by representatives of Yad Vashem took Geissler by surprise. Celestine Bohlen describes the situation as Geissler understood it:

He received a letter from Mr. Kaluzhni, dated May 17, 2001, saying that a group from Israel was ready to pay $\$ 3,000$ for the murals, which, according to the city, had become his property through the process of privatization. In the letter Mr. Kaluzhni said he had refused the offer but two days later, the crew from Yad Vashem, led by a Ukrainian immigrant to Israel, arrived. ${ }^{30}$

Geissler's film shows the pantry after the murals have been removed. Where the murals used to be, now there are irregularly shaped holes in the plaster.

The picture is destroyed, Mr. Geissler said [to Bohlen] in a telephone interview from Hamburg, and nobody will know the whole picture. For me, it is very tragic to see Bruno Schulz only as a Jewish victim or only as a Polish writer. He is simply Bruno Schulz, and this is a violent postmortem attack against him. ${ }^{31}$ 
Between 2001 and 2008, the literary world in Poland and Israel expressed a range of views on the best location for the murals and Yad Vashem did not display them. Often the reaction split along cultural lines. Poles: outraged. Ukrainians: also outraged but less noisily. A Jewish survivor from Drohobych, now living in Israel: initially amused, and then mentioning the word 'complexity'.

In his film, Geissler interviews two elderly Jews who have remained in Drohobych. In case we might think there is no Jewish community in Drohobych and its surrounding area any more, Geissler provides figures on how many Jews live there now. One man says he has stayed so that he will not be buried in Germany. A toothless woman, sitting in front of a sagging curtain and piles of books, says she has stayed to guard the remains of the Jewish culture of Ukraine. She speaks, without noticeable emotion, of her unsuccessful attempt to persuade the library at Lvov to make a designated space for Jewish books and of her synagogue, which has been set alight four times in the last ten years by nationalist groups.

Jews in Israel do not understand why we have stayed here, she says. After this she recites a list of why Jewish people have stayed in Drohobych. Her voice rises and rises as she gives reason after reason. I did not really notice this list until the fifth time I watched the film, but now I regard it as one of the most significant and beautiful parts of the film. The more I believe that the woman's quest is doomed to failure, the more beautiful and significant the list sounds. 


\section{Press release from Yad Vashem, 27 February 2008:}

Today, Israel and Ukraine signed an agreement relating to the Bruno Schulz works located at Yad Vashem. The agreement was signed by Pinchas Avivi, Deputy DirectorGeneral and head of the Division for Central Europe and Eurasia in the Israeli Foreign Ministry, and Ukraine's Ambassador to Israel Ihor Tymofieiev, in the presence of Ukraine's Vice Prime Minister Ivan Vasyunik.

According to the agreement, the Schulz works, currently located at Yad Vashem, will be recognized as the property and cultural wealth of Ukraine, and will be on temporary loan at Yad Vashem for 20 years, after which the loan will be automatically renewed every five years.

Bruno Schulz was born in Drohobycz (then Poland, today Ukraine). A Jewish author and artist, he was forced to embellish with fairy-tale protagonists the walls of the children's room in a house occupied by Nazi officer Felix Landau. He was later shot to death by an SS officer on a day of pogroms in the city of Drohobycz, only because he was a Jew. Some 60 years after they were made, the works were discovered in a state of neglect and disrepair. Yad Vashem acquired the works, with the agreement of the family, in whose home they were found, and the approval and blessing of the Mayor of Drohobycz, and a team of experts brought the works to Yad Vashem in 2001. Since that time, they have undergone professional conservation to keep them in the condition in which they were found and to ensure that no further deterioration of the materials and colors occurs in the future. ${ }^{32}$ 
Benjamin Geissler's new work is called The Picture Chamber of Bruno Schulz: the Final Work of a Genius. This work showed in Hamburg during the European summer of 2012, and as I write this in November 2012, is showing in Luxembourg. The Picture Chamber of Bruno Schulz: the Final Work of a Genius is a re-construction of the way Schulz's murals looked in May 2001, in the pantry in the former Communist clerk Kaluzhni's old apartment, in what some still call the Villa Landau in Drohobych, after the murals were uncovered but before three were removed by Yad Vashem and five by the government of Ukraine.

I wonder how it reads in Luxembourg.

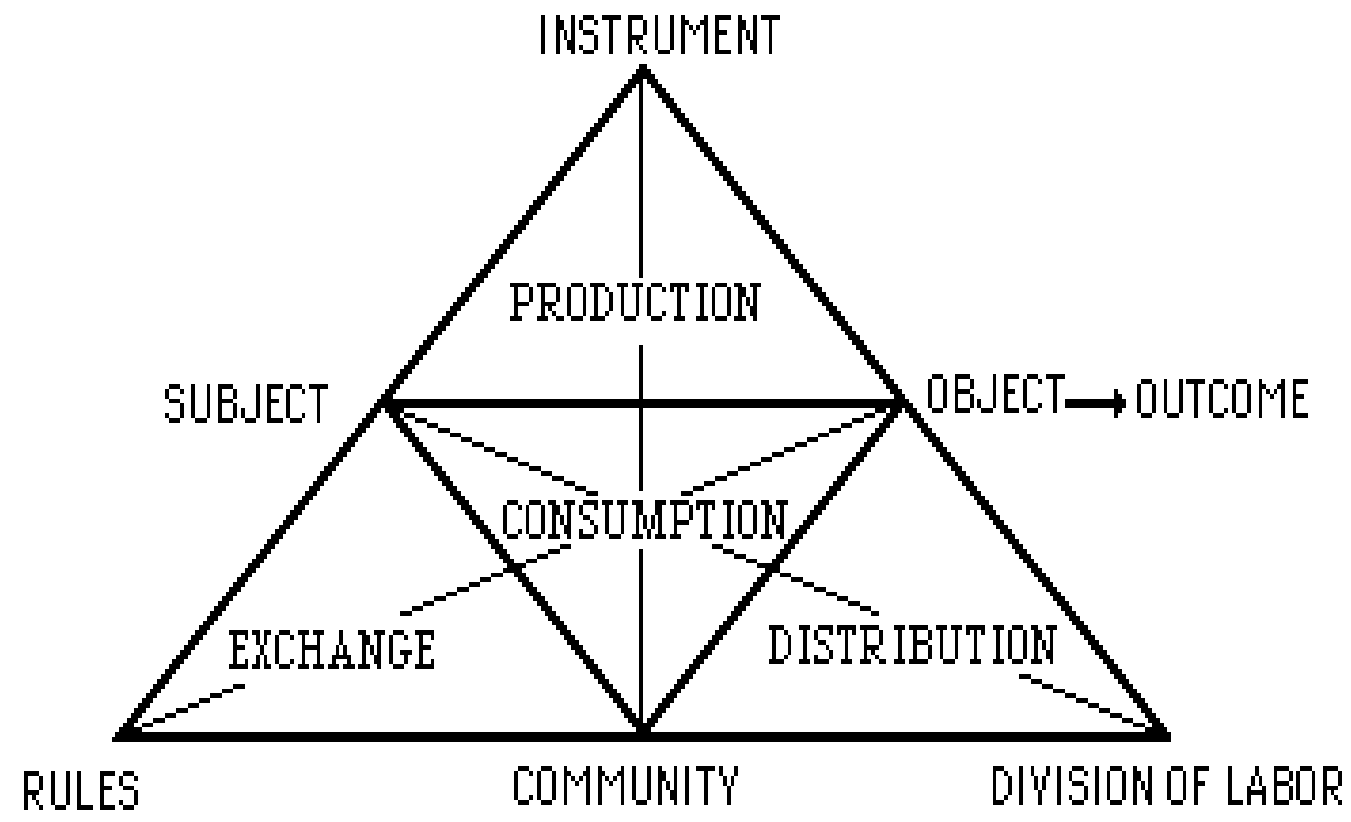

"The structure of human activity" 
Papyrus was a good material. It gave people a way of recording ideas and passing them easily from one person to another. But it took a lot of time and some effort to make this place to put writing. The first step was to find the papyrus plant. Cyperus papyrus, the Egyptian papyrus plant, was common in ancient Egypt, growing mostly along the edge of waterways. It will grow in any sunny location that does not receive much wind and has constantly saturated soil, such as around a pond or on the banks of a river. The saturation of the soil needs to be several feet deep.

To make papyrus, you strip off the outside layer of the stem, and cut the inside soft part into even-sized strips. Then you pound them. You lay the strips side by side to make the first layer. Then you make a second layer, laying the strips at right angles to the first layer. Last, you wet the whole thing and put a rock or some other heavy object on top and leave the wet squishy pile of material for about three weeks. The juice of the papyrus plant glues everything together and the rock and the heat of the sun make the squishy plant material thin and solid. At the end of the three weeks there is a surface to write on. One piece of papyrus might be twenty centimetres square.

Since it took at least twenty layers of wrapping to encase a mummy, it is thought by archaeologists that the fragment known as L.P.67, which was found in the late nineteenth century C.E. wrapped around a mummified crocodile, is an ancient example of re-cycling.

The fact that the wrappings of the crocodile were found to include fragments of papyrus covered with writing and that one of these fragments was later included by scholars in the body of poems attributed to Sappho was thought to mean that at the time of making the mummy, the poem by Sappho was seen as less valuable than the piece of papyrus. 
I came upon The Moniac while conducting an exploratory visit to the Reserve Bank of New Zealand Museum to see my first museum of money. After viewing a film of the Queen's 1954 visit to New Zealand and opening drawers of coins from my childhood, I saw The Moniac, silent in its glass case. It looked a little like a complex form of paint-mixing machine, with lots of tanks of liquid, plastic funnels and rubber tubes leading to other tanks, all of different sizes, and the whole mechanism mounted on a wall of what looked like galvanised steel. Despite its rough and ready appearance, there was something imposing about it.

Clearly, like the note-bundling machine I had just seen, The Moniac had some practical purpose. Its materials, its purposefulness and its complete lack of interest in appearance, when added together, told me immediately that it was built by a New Zealand-born man sometime between 1946 and 1960. But what was its purpose and how did its complex hydraulics match its name, which seemed to be a combination of 'money' and 'maniac'? I read on the information card beside the glass case that The Moniac was originally calibrated to represent the economy of Great Britain, and this gives me pause for a few minutes, but then I realise this is a familiar colonial situation, so I am confident that it will make an effort to extrapolate to the New Zealand situation. After all, the inventor of The Moniac, Alban Housego Phillips, was from a dairy farm in New Zealand and therefore, at its core, his machine would surely retain an occult sensitivity to our concerns.

I had progressed no further with my deductions when the museum attendant approached. She told me that The Moniac was designed to allow predictions of money flow in a macro economy, and that the very next day, being the first Wednesday of the month, beginning at 12.15 and ending at 12.45 , there would be a full working demonstration of The Moniac, during which it would answer a question selected from the audience.

It was four o'clock by this time. Four o'clock is always museum-closing time. As I left, the attendant gave me a plastic bag of shredded bank notes, a booklet about how to invest money wisely and a lollipop. I also took some postcards of The Moniac with me, as many as I thought I could get away with, and a brochure about the machine and its maker. 
While imprisoned by the Japanese in Java during World War II, Phillips built a radio hidden in a wooden clog and an immersion element, run from camp lighting, to boil water for hot drinks. Phillips built the first Moniac while he was studying at the London School of Economics, for a cost of only $f 400$, using parts from a Lancaster Bomber. ${ }^{34}$

The words 'Lancaster Bomber' slide easily into my mind and into this text. I feel as if I know what a Lancaster Bomber would look like, even though I was not born for nearly ten years after the war. I also feel strangely comforted by the words 'Lancaster Bomber', as if these words were the name of a virtuous thing, like a guide dog for the blind.

A few days later I was still thinking about Lancaster Bombers. I wondered if the behaviour of this word in my company meant it was part of my 'collective memory'. Then I read an account by a prominent New-Zealand-born journalist of his bypass operation. This man, who was born in 1945, described a period of hallucinations after his surgery, in which he was certain he was responsible for making Lancaster Bombers. The task weighed heavy on him. Later this weight turned out to have been an infection in his heart, but the fact remains; in his deep dream state, the most famous of the World War II night bombers and a sense of responsibility were there, together, waiting for him. 
A while ago I found a piece of paper on the road while I was out walking. In the bottom left corner of the paper was the FlyBuys logo and in the bottom right corner, these words:

Loyalty New Zealand: Customers for Life. There was writing on it; the words, written by hand in ball-point pen, becoming less distinct further down the list, as if the writer was perhaps attending some sort of training and becoming bored or tired.

This is what it said:

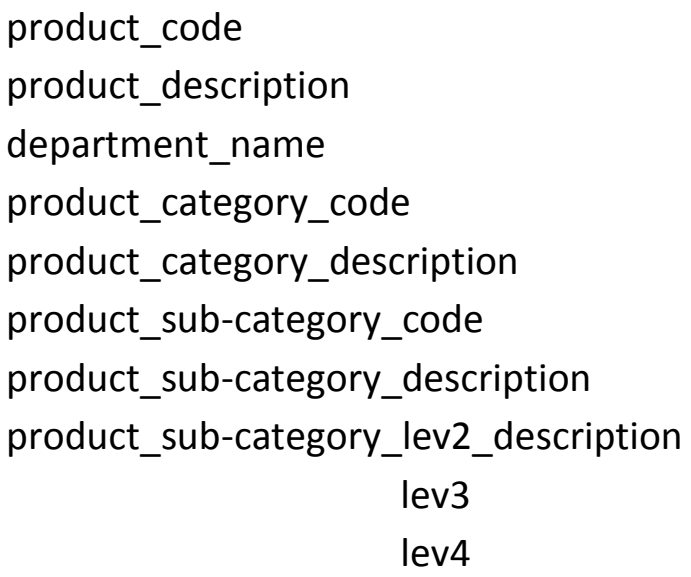

Its meaning is not obvious to me. I have kept this piece of paper for more than a year, tucked away in a file box, but from today I will be less interested in its preservation, feeling that, by incorporating the document into this record, I have carried out any archival obligation I took on by picking up the piece of paper.

There is no more I can offer regarding the context and provenance of the document other than to say I found it in Renown Road in Raumati South on 19 September 2011. Someone else at some long distant future time might be able to unearth the context and intended meaning of this rubric. 


\section{Guy Davenport:}

There is so little Sappho that the reader with even a little Greek can read the substantial fragments in an afternoon. There are many fine translations of Sappho in English (though none, to my knowledge, that includes all but the utterly hopeless fragments without whole words in them anywhere), and the only excuse for making a new one lies in the richness of her poetry: each translator reflects what he sees, performing not so much a linguistic as a critical act, the closest possible rendering of his appreciation. Many of the fragments are mere words and phrases, but they were once a poem, and, like broken statuary, are strangely articulate in their ruin. ${ }^{35}$ 


\section{Three myths from a far-distant future}

who by fire

and who by something blunt

Hank Williams

water song barbiturates

Hallelujah

Cultured people will say that they like these particular floating words, even though scholars say they are the only people who know what the words mean. Cultured people will not care about this and will wonder if perhaps the scholars are lying in order to advance their careers. Cultured people will like the sounds too and say at parties that they feel something complicated when they sing the first three words in this rhythm.

Da-da-da (rising inflection)

Da-da-da (rising inflection)

Traders will say that the poet was a small man who had a taste for whiskey and expensive suits. In a rather sad voice they will say he inherited enough money that he did not need to take up selling suits himself as his father had done, but stayed in his youth in an artists' hotel in New York, on an island in Greece and later on a mountain in California, wasting his father's money and writing poems and songs. (They believe that until he died, he spoke with an accent from his father's country.) Most importantly, they say, late in his life, having lost his fortune due to inattention, the poet resolutely set about making a new one. In his own time, and afterwards, his poems and songs were performed by thousands of others, so that the number of people who knew his songs grew and grew, which made him wealthy again before he died and even more wealthy after his death.

Poets, artists and keepers of goats will say that the poet was a priest with certain ritual obligations and could trace his ancestry all the way back to a sorcerer who was able to turn a stick into a serpent. And this: He had at least three names, one of which means 'silence'. They will choose these names often for their sons. And this: The poet used words from other poems and songs, which, by the time the words reached him, were so old that no one knew how old they were. 
These old poems and songs had projected themselves towards the poet singer through at least two other languages, one of which no one spoke any more, and embedded themselves in his body before he was old enough to notice. They dream of such penetrations.

And this: These old poems and songs had been remembered because they had consoled many people in times of fear and isolation and also because the old poems happened to belong to men who wrote them down on the skin of a goat, albeit with no vowels or punctuation.

At this time it is the custom for poets to begin their stories with the words:

And this 
Notes:

${ }^{1}$ Schulz, Bruno. "Spring." The Street of Crocodiles and Other Stories. Trans. Celina Wieniewska. London: Penguin Books, 2008. Print. 142.

${ }^{2}$ Rev. of From Ur to Rome, by Kathleen M. Gadd. Greece and Rome 7. 20 (1938): 123. Cambridge Journals Online. Web. 14 Sept. 2012.

${ }^{3}$ Du Bois, Page. Slaves and Other Objects. Chicago: The University of Chicago Press, 2003. Print. 39-42.

${ }^{4}$ Woolley, Leonard. Digging up the Past: The Romance of Archaeology. London: Pelican Books, 1937. Print. 33.

${ }^{5}$ Benjamin, Walter. "No.113." One-Way Street and Other Writings. Trans. Edmund Jephcott and Kingsley Shorter. London: Verso, 1979. Print. 47.

${ }^{6}$ Freud, Sigmund. "A Disturbance of Memory on the Acropolis." (1936) Standard Edition of the Complete Psychological Works. 2nd ed. Trans. J. Strachey. London: Hogarth Press and The Institute of Psychoanalysis, 1964. Print. 22: 239-248.

${ }^{7}$ Carson, Anne. If Not, Winter: Fragments of Sappho. Trans. Anne Carson. New York: Vintage Books, 2003. Print. 137.

${ }^{8}$ Way, Arthur S. Introduction. Sappho, Vigil of Venus. Trans. A.S. Way. London: Macmillan and Co. Limited, 1920. Print.

9 West, Martin. “A New Sappho Poem.” The-t/s.co.uk. 24 Jun. 2005. Web. 10 Dec. 2010.

${ }^{10}$ Kurtz, Glenn. "What Remains: 'Sappho and Mourning." Southwest Review 95, 1 \& 2 (2010): n. pag. poems.com. Web. 08 Feb. 2011.

${ }^{11}$ Wagner, Heather. "Jonathan Safran Foer Talks Tree of Codes and Conceptual Art." Vanityfair.com. Vanity Fair 10 Nov. 2010. Web. 23 Jun. 2011.

12 My poems "Now again, grasses wave" and "Keas call for me" are mostly made up of words from "Blue Jeans". Thoughts from the High Country. 1995. Naseby, New Zealand, 1999.

Print.

${ }^{13}$ Way. Preface. Sappho, Vigil of Venus.

${ }^{14}$ Sweenykovar. Sweeneykovar.wordpress.com. n.p. 29 Oct. 2007. Web. 28 Jun. 2010. This blog has now been deleted.

${ }^{15}$ Brett, Thomas. Brettworks.com. 11 Feb. 2011. Web. 30 Jul. 2012. 
${ }^{16}$ Ibid.

${ }^{17}$ And Europe Will Be Stunned. Dir. Yael Bartana. 2011.

18 Powell, Jim. Sappho: A Garland: The poems and fragments of Sappho. Trans. Jim Powell. New York: Farrar Strauss Giroux, 1993. Print. 37.

19 "Ancient Lives." ancientlives.org. University of Oxford. n. d., n. pag. Web. 10 Sept. 2012.

20 "When is a Biscuit Tin Not a Biscuit Tin?" HuntleyandPalmers.org.uk. n.d., n.p. Web. 22 May 2010.

21 "African Boys, about 1903." Photograph and caption. HuntleyandPalmers.org.uk. n.d., n.p. Web. 22 May 2010.

${ }^{22}$ Woolley 35-40.

${ }^{23}$ Grenfell, Bernard P., and Hunt, Arthur S., Letter. The Times. 14 May 1906. Qtd. in Reynolds, Margaret. The Sappho Companion. New York: Palgrave, 2001. Print. 290.

${ }^{24}$ Woolley 16.

25 "Secondhand Sureshots: Each Snap, Crackle and Pop Tells The Story."larecord.com. 7 Dec. 2008. n.p. Web. 28 Jun. 2010.

${ }^{26}$ Geissler, Benjamin. “Drohobycz.” Benjamingeissler.de. n.p. Web. 9 Sept. 2012.

${ }^{27}$ Schulz 141.

${ }^{28}$ Finding Pictures. Dir. Benjamin Geissler. Benjamin Geissler Filmproduktion, 2001. DVD.

${ }^{29}$ Bohlen, Celestine. "Artwork by Holocaust Victim is Focus of Dispute." Nytimes.com. 20 Jun. 2001. New York Times. n. pag. Web. 26 Oct. 2012.

30 Ibid.

31 Ibid.

32 "Israel and Ukraine Sign Agreement Today on Bruno Schulz Works Located at Yad Vashem." yadvashem.org. 28 Feb. 2008. Web. 26 Oct. 2012.

${ }^{33}$ Engeström, Yrjö. Learning by Expanding: An Activity-Theoretical Approach to Developmental Research. Helsinki: Orienta-Konsultit, 1987. Print. 76. 
${ }^{34}$ A.W.H. (Bill) Phillips, MBE and The Moniac. Wellington: Reserve Bank Museum, date unknown. Print.

${ }^{35}$ Davenport, Guy. Preface. Sappho, Poems and Fragments. Trans. Guy Davenport. Ann Arbor: The University of Michigan Press, 1965. 19. Print. 


\section{Part Two: History-making}

This chapter is justified and has wide margins. I like the way this concentrates the text. 
When I tell people that I am interested in the subject of missing people, everyone has something to say. They tell me about people who vanish every year while on an ocean cruise, people who have been missing for ten years but someone, maybe an obsessed police officer, now retired, or a mother, is still looking for them. They tell me about adopted children who have never found their biological parents, mothers who have lost their children, women who grieve for children they never bore and men who have lost touch with their children. They also tell me about invasions and theft and colonies and predators and diseases and the loss of generations.

Often the scenario they tell me about is one of which they have some personal experience, like the story told by a man who runs a museum dedicated to the Holocaust, who speaks of the empty chair at the dining table the day after his father died. The family stood and stared, he says. They had food but could not eat. No one knew what to do, until his mother told him to sit in his father's chair. Although he had worked in the Holocaust museum for a number of years, this particular empty space taught him something new about absence, he said. 
At 7.30 am on Saturday 4 September 2010, my mother phones with news of the first earthquake. She does not say that she was frightened. She talks about the cat, which is lost, and how cold the house is. I take the first flight. I don't know how long I will be in Christchurch so I buy a new e book reader loaded with a hundred classics. e reading anywhere, anytime it says, as it powers up. It looks primitive, like one of those early mobile phones.

Soon after I arrive, my mother tells me that the big earthquake roared like a wild animal. I assume a lion, but she says the roar of an unknown animal. That is the problem. According to the newspaper the roar of an earthquake is the sound made by the fault slipping. It makes this noise with no consciousness or purpose, my mother says. I picture her waking to the roar of a lion. Stopping to put on her dressing gown and slippers and pick up her torch. No lights at the neighbours', no streetlights, no teeth. Broken glass under her feet. The bitter frost.

My bed floats like a dinghy in the turning tide. After three days the cat returns. Takes up residence behind the tv but comes out at night to sit at the window, staring in the direction of the fault. Each morning I inspect cracks in the concrete to see if they have grown. I take photographs of these cracks. I follow instructions for water sterilisation and I clean salad vegetables in boiled water. I feel breathless, as if somehow I can't keep up.

Tolstoy helps. 'The answer which life gives to all questions is: one must live in the needs of the day.' I wonder if his flat tone, which I savour as a form of wisdom quite separate from his words, is an artefact of translation.

According to the newspaper, an earthquake has two energy waves. The $P$ wave is fast and travels through crustal rock. The $S$ wave arrives later. It cannot pass through liquid or penetrate the earth's outer core. Sometimes there is no warning sound. The nature of earthquakes allows for this. You can almost give these things a personality, says the man who was duty seismologist on a night with twelve aftershocks. It sometimes feels like they're out to get you. 
The first duty of the duty seismologist is to offer reassurance. The more faults we find that have slipped, the better, he says. Strain on all the region's faults has been reduced. Etc. Sometimes the cracking can be a new fracture, but mostly, and always in large quakes, the ground gives along existing fault lines.

There's the excitement of the fault itself, but then I talk to people who were affected and it's very sad, says a scientist for whom English is a third language. Experts have come from many places to see the earthquake. Immediately there is conflict. Bedrock gets loaded up with stress because it is being dragged on from underneath, says a lecturer in Geological Sciences. It's beautiful, says one of his post-graduate students, one side insisting on change, the other resisting. Change prevailing.

I meet a woman who keeps a turtle. On the night of the quake she found the turtle, wrapped him in a towel and held him on her lap. When daylight came, she saw that he was bleeding from a long cut on his neck. How strange, she says, that a sharp piece of glass found the only soft part.

Hyacinths. My mother cuts hyacinths and puts them in a vase on the kitchen windowsill. There were hyacinths the day her baby brother was born. Two days after I left, my mother tells me, she sat down in her armchair, thinking to do the crossword, and found herself crying. Unable to stop.

After that, whenever I go to Christchurch, I reach for the Russians. The first time was an accident, if there is such a thing as an accident in a writer's choice of books. Anna Karenina happened to be in the collection of 'free' books in my e reader.

As I fight for composure, give in to fear and frustration and generally behave badly, it comforts me to see Tolstoy's steady gaze falling on his book people. They blunder about, giving in to every sin, causing great pain, and he lets them fall. 
They are afraid. They are terrified. They are sick. They catch deadly diseases, fall into debt or under a train, and nothing saves them.

I have taken several Russian books with me now, usually in physical form, and each time I have found the book warm in my hand. Not dry and cool, like one of our own books, but leaking salt and blood. As different from us as the men we used to see from the Russian trawlers, wandering in groups down the main street of Dunedin in the 1970s. They were just men, wearing trousers, shoes, a shirt, a jacket, walking in a group of four or five, looking in shop windows, as people do in a new town. But their faces were carved in stone. It seemed as though they kept themselves separate from us for some reason. Maybe it was forbidden to talk to us? Maybe it was just that they couldn't speak any other words of English except 'beer' and 'how much'?

In Christchurch, where the smell of toast and the morning sun coming in the kitchen window protect no one, where the wind howls at night and the ground rumbles, I may have read into these Russians something incorrect. Stripped of their native context, of their sounds and rhythms, passed through time and placed in a foreign language, they are defenceless.

One night, having finished Anna Karenina, I am scanning the index of my e reader and I find The Communist Manifesto. I have never read it before, although, like everyone, I have heard of it. It is easy enough to read. It sounds like the minutes of any group, except that this group is seeking 'the forcible overthrow of all existing social conditions'.

At home again, I decide that the e reader is horrible and put it somewhere. Soon it is under a pile of books and I tend to forget that I own it. I buy a second-hand paper copy of Anna Karenina and The Communist Manifesto and I read them both again, enjoying turning pages and folding down the top corners of their pages when I find something I want to come back to and think more about. 
I would never write comments in the margin in ballpoint pen, as a certain Jonathan Martinez has done, in my second-hand copy of Slaughterhouse Five. 'Dresden - Place of war', he has written on page 1, above the first sentence of the book. He continues, labelling every metaphor and every simile in the book, not always correctly. 'Anaphora', he writes, after every repetition of 'So it goes'. Anaphora makes a nice noise when said out loud, so I say it out loud whenever I find it in the margin. It begins to sound like a blessing. 'German', writes Mr Martinez after every word or sentence in German.

After Kurt Vonnegut died I thought a lot about him. I read that one day he picked and ate berries which had ice crystals inside, left over from winter. Picking and eating these icy berries was one of the best moments in his life, he said. After that I wrote to him, care of atheists' heaven as he suggested, thanking him for never writing any bad guys and promising to follow his father's advice about making sure to notice pleasant events. At this time I bought a second-hand copy of Slaughterhouse Five to replace the copy that drifted away from me sometime in the 1980s, and in this way, met a version of Jonathan Martinez.

From now on Mr Martinez and I will always read this book together. $\mathrm{He}$, as he was one day, perhaps in his eighteenth year, and I, however I am on this particular day. So it goes. 
I have begun to read about how to disappear. The number of books and online guides about how to disappear is surprisingly large. Usually the authors are men in their forties who have an excellent understanding of technology. They write with a sort of compressed urgency, as though they hope against hope that the reader, who is far too casual in these matters, will pay proper attention to all the advice and put each and every step in place correctly. If a person does this well enough, he will not be found. It is that simple. The steps themselves require so much planning that a person who was only half wanting to disappear would give up by the end of the second chapter.

So who might follow all these intricate instructions? I am interested in this question but the books don't interest themselves in reasons. They treat disappearing as something that some people will need to know about, like buying property for investment perhaps, and they don't talk about how a person might have landed in a situation where disappearance is the only sensible option.

And supposing that I followed all the advice and disappeared, what would that mean? This topic does not get much attention in disappearing books either. In three books there was nothing at all. A disappearance expert in a television programme made one use of the word 'margins', one each of the words 'solitude' and 'temptation' and one of the phrase 'old haunts'. Obviously this man had heard from beyond the wall. Perhaps a brief phone conversation on a new pre-paid phone? Perhaps an email with no pronouns or definite articles, like a telegram, sent in haste from an internet café? My guess is that he does not want to hear about solitude and temptations and second thoughts and has a policy not to take calls from beyond the wall, but somehow the odd one gets through. 
For the next few weeks, The Communist Manifesto stands open near my right hand. In my office it is 1848 , the year Marx and Engels finished writing down their beliefs and intentions in this strange informal document. It is simultaneously 1888, when Samuel Moore made his English translation, and 2010, when intellectual property is more valuable than real estate and Communism is reported to be dead along with class consciousness and unions.

The Communist Manifesto is a small book. My copy measures $10 \mathrm{~cm}$ by $8 \mathrm{~cm}$ and has only 55 pages. Despite its size it catches the eye of everyone who comes into the room. It excites people in a strange way. 'Oh' they say, 'It's so small. I thought it would be the size of War and Peace.' Or they laugh. 'What are you doing with that?' they say, as if it was a book of smutty jokes. I notice that no one picks it up.

On the cover a young man in a worker's cap holds a red flag in his hands. His shoulders are squared, his legs are slightly apart and he stares straight ahead, already a square-planed, steelstrengthened Soviet sculpture. Behind him a man reads out loud from a paper; three men are listening and one older man looks inside himself. All wear heavy boots and caps. In the background there are concrete arches. Perhaps they meet in a cellar, or under a bridge? In 1848 and 1888 it is dangerous to meet and hear these words.

'The Communists disdain to conceal their views', says the final paragraph of the Manifesto. 'They openly declare that their ends can be attained only by the forcible overthrow of all existing social conditions." ${ }^{\prime 1}$

As the Manifesto says, 'It is high time that Communists should openly, in the face of the whole world, publish their views, their aims, their tendencies, and meet this nursery tale of the Spectre of Communism with a manifesto of the party itself. ${ }^{2}$

I love the use of the word 'tendencies' here - the way it includes complexity. Views, aims, tendencies; nothing I have been told about Communism was as soft and inclusive as these words. 
So what is a tendency? A moored boat in an incoming tide will have a tendency to move closer to the shore, but its position will always be a reflection of a sum of forces. 
On 22 February the third major earthquake in Christchurch caused major damage to the old Wood Brothers flour mill in Addington and to thousands of other buildings. On 15 March 2011, less than a month after the earthquake, the flour mill was demolished.

The Urban Search and Rescue Team, charged with protecting people from unsafe buildings, assessed it as dangerous and began proceedings to have it deconstructed. This meant it would be taken apart and materials salvaged, including about $\$ 600,000$ worth of Oregon pine timber which lined the walls. But somehow the plan changed and it was demolished. No timber was salvaged.

On 16 March a woman called Sophie posted this question: ${ }^{3}$

Was there anything that gave that demolition co the right to knock down the whole flour mill, then??

After this, a technical exchange occurred regarding Acts and Orders and Insurance. On 18 March 'Mr Man' said,

If in doubt DEMOLISH IT!!! Simple huh, do you really want more deaths to come from unstable structures whether they're heritage or not. Please oh please let them demolish every building with any doubt of its structural integrity, regardless of its history.

In this early period Civil Defence authorities demolished or partly demolished 306 other buildings in the central business district. 
In September $1920 \mathrm{Mr} \mathrm{H}$. G. Wells and his son, who spoke a little Russian, went to Petersburg (sic) and Moscow at the invitation of the Russian Trade Delegation in London. Wells writes of this visit in his book Russia in the Shadows, using, in his writing, the same tone that he uses for his talks on the BBC, which are accessible on YouTube. There is something atavistic and therefore reassuring about this tone, as if he has seen what other men fear and has returned, safe and sound, with valuable information under his arm. He sounds completely confident that any sensible person would, upon listening to these points, be convinced of their truth. Here is a tiny example of his tone:

Ruin; that is the primary Russian fact at the present time, he says. The revolution, the Communist rule ... is quite secondary to that. It is something that has happened in the ruin and because of the ruin. It is of primary importance that people in the West should realise that. If the Great War had gone on for a year or so more, Germany and then the Western Powers would probably have repeated, with local variations, the Russian crash. ${ }^{4}$

Wells and his son travel to the Kremlin especially to meet Lenin. After a journey through many rooms, each containing a desk and a number of officials, they find Lenin, a little man with a lively smile, seated at a great (and messy) desk near a window which looks out on huge spaces. A Mr Rothstein chaperones and photographs the occasion. 
A photograph with the caption 'Messrs Lenin and Wells in Conversation' shows Lenin looking at Wells, his head in one hand as if he is tired, his expression amused. I have tried to capture the essence of their exchange by exaggerating slightly a rhythm I noticed in Wells's account:

Wells: What do you think you are making of Russia?

Lenin: Why does the social revolution in England not begin?

Pause

Wells: Communism in Russia pressing too hard and too fast, destroying before it was ready to re-build...

Lenin: No. The inevitable class war, the downfall of Capitalist order as a prelude to re-construction, the dictatorship of the proletariat...

Pause

Wells: The existing Capitalist system can be civilised into a Collectivist world system ...

Lenin: No. Modern Capitalism incurably predatory, wasteful, and un-teachable. Until destroyed [it] will exploit the human heritage stupidly and aimlessly, fight against any administration of natural resources for the general good, and because it is a scramble, will inevitably make wars...

Pause

Lenin: . . . and by the way, what do you think of this new Republican imperialism that comes to us from America?

(Mr Rothstein spoke to Lenin in Russian at this point. Urging more diplomatic restraint, according to Wells's son.)

Wells: Well some industrial power has to come in and help Russia reconstruct...

And that, according to Wells, was the end of the meeting. 
Afterwards, Wells is not disposed to talk, he says, wanting to 'think Lenin over while he had him fresh in his mind'. ${ }^{5}$ But Rothstein keeps on talking; pressing the need for a veil of discretion to be drawn over Lenin's comments about America long after Wells had given reassurance on this point. See under: social skills of Jews.

Wells leaves the meeting 'refreshed', full of admiration for Lenin's 'frank admission of the immensity and complication of the project of Communism and his simple concentration on its realisation'. ${ }^{6}$ Still entranced months later, he calls this chapter of his book "The Dreamer in the Kremlin".

I am particularly struck by a description in Wells' book of the Expertise Commission, a body set up in the former British Embassy, to gather together and catalogue, from the houses and palaces taken over by the Bolsheviks, every object that could possibly be called an artwork. And there it all is, gathered together; rooms and rooms of it, catalogued and counted, occupying a building large enough for thirty families. Wells has a photograph of the room set aside for chandeliers, hat stands and mirrors in his book. The problem of all these objects took the Bolsheviks by surprise, says Wells:

I could not find out that anyone had an idea of what was ultimately to be done with all this lovely and elegant litter . . . They never anticipated that they would have to deal with such things. Just as they never really thought about what they would do with the shops and markets when they had abolished shopping and marketing. ${ }^{7}$

Reading all this, I too have a huge surge of admiration for the Russian experiment. But nothing is simple. From the winter of 1920, Dr Zhivago looks over my right shoulder; he is starving, whispers that he would sell anything for four logs of wood. He treats typhus every day, but the word must not be said. He writes lyric poetry, which is a crime but he does it anyway. Arkady Renko arrives in my kitchen half drunk and stinking. 
He smokes thirty cigarettes a day, because why wouldn't you smoke if you were eating a lifetime's radioactivity with each meal?

On an impulse I invite them all for dinner: Renko, his deathly Ukrainian girlfriend, the orphan boy he tries to look after, Wells, his son, Lenin, Rothstein, Trotsky the great organiser, Zhivago whose heart is failing, Tonya and Lara and the woman he lives with just before he dies, his son Sasha, his lost daughter Tanya, all the guests at the Petersburg Home of Rest for Workmen, and Gorky, fresh from his work finding food for artists in Petersburg. 
I make borscht. I have everything to hand: six boats of garlic, a plastic container of sour cream contaminated with hormones and heavy metals, a long slow river, two big-breasted grandmothers, four scavenging bears, one mass grave, one mother, two diamonds, fifty litres of unskimmed chicken stock, three big sacks of potatoes, ten cabbages and three kilos of beetroots. This will be enough to give sixty people two servings. (It is the Russian custom to fill up your guests to the top.)

To create that exceptional Russian atmosphere I set the table with a red tablecloth, place a flag in the window, a couple of Russian books on the window sill, a knitted scarf over one chair, a Russian army jacket over another, a magnet with Medvedev and a piece of Russian modern art on the fridge, plus three glasses for each person - for vodka, beer and wine. The vodka must be Russian, but the beer could be Czech or Polish, and for the wine ... anything red will do.

A good choice for background music is the Russian Army Choir, which has made some excellent discs. The first song to play, of course, will be the Russian national anthem . . . and then my guests will be ready to enjoy their borscht. There will be black or grey bread; white bread in this context is a big no-no. We'll start the meal by making a toast with ice-cold vodka and then biting off some salted cucumber. We'll toast each other until the vodka is finished. Then I'll quickly serve the borscht. (It is the Russian custom to leave your guests where they fall.)

In the morning a young couple and a little boy will be leaving on a four-day train journey from which they will never return, and a necklace given as a farewell present will have been mislaid. For a short time everyone will think a thief has walked through the fallen tangle of guests and taken the necklace, but it will be found in the film-star hair of a sleepy young girl. 
24 February 2011, two days after the Christchurch earthquake in which 185 people died. On my way home from a poetry reading at which a woman collapsed, I found a memory stick on the floor in the ladies' toilets at Wellington Railway Station. I opened the files to see if I could, and, after reading the names of all the files, I looked to see what they were about.

The memory stick contained the field notes of an anthropologist studying violence in an island society in the South Pacific. One file was titled The universal Glossary (sic). Although it sounds like some sort of specific term, I have not been able to find any other reference to a 'universal glossary' except for one unexplained mention in an Indonesian software manual.

The words and phrases below made up The universal Glossary on the memory stick. I have provided only the English, in the original order:

Customary Law

Traditional ruling class

Village

Sub-village

Neighbourhood

Head of Village

Bride price

Dowry

Rape

Slaves

Magic potions

Ritual experts

Sacred, having magical powers

Western

Native population, as defined by colonial classification system 
Assimilated natives, as defined by colonial classification system

Important person, as defined by colonial classification system

Land cleared of forest

A bird, now extinct, greatly prized by colonists for its feathers

Abandoned gold mines

Forced labour system

Member of clandestine resistance network

Soldiers who have returned home

Soldiers who died

Soldiers who are still missing

Confiscated land

Sickness caused by hunger

Sickness caused by shame

Protective amulets

Prostitutes

Widows

Children of women raped by soldiers

Land thought to contain mass graves

Anti-western sentiment

Aid worker

Members of my writing community have expressed disapproval of my actions regarding the memory stick and also disgust that I picked up an object from such a dirty place. In my defence I will say that no password was required to open the files on the memory stick and that this carelessness is surely irresponsible. 
Nothing in Christchurch is the same. This morning, for example, I heard that the sign for Christchurch in New Zealand Sign Language has changed. Before the earthquakes you made two Cs, one after the other, both with the left hand cupped, the Cs both facing the same way. Now you use both hands. You make two Cs facing each other, one above the other like a two-storied building. Then you move the Cs towards each other and away again. It looks like a building rocking, broken in the middle. I am not sure how official that change is, or whether it will last, but for now, that is Christchurch in the language of the deaf.

Every evening from the day of the earthquake some call 'Old Bucky' until perhaps October 2011, my mother tells me the number, location, depth and size of all the earthquakes in the last twenty-four hours:

East of Lyttelton, 3.4

West of Lyttelton, 2.7

Near Little River, 4.2

Rolleston, 2.8

Lyttelton, 3.8

Simeon St, 4.2

Lyttelton, 4.1

Lyttelton, 2.3

Port Levy 2.3, and so on.

With this nightly roll-call goes a strange feeling that everything I had loved and everything that I hated about Christchurch has been lost. I can't really explain why this is so disturbing when I haven't lived there for more than forty years, but it is.

In New Zealand English this is a feeling with no name. I don't believe a name would help. 
Knowing my interest in loss, people have said to me that I should write about what has been lost in Christchurch since the earthquakes, but on the whole I can't. I have listed a few things I noticed on my visits in 2011, the year after it all really began, but that is not to be taken as any sort of actual account. And in any case, as I write this, late in 2012, things are already different. 
I came across James Cowan's Maori Folk Tales of the Port Hills in Quilter's second-hand bookshop, in Ghuznee Street, Wellington, in April 2011. The book was in the window, a sign of the owner's confidence that it would easily find a buyer. I was first attracted to the book by the title and then by an oldfashioned-looking cover illustration of a mountain I know as 'Sugarloaf'. I had never heard of its author.

A publisher's note in the front of the book says that the first edition was published in 1923 and that illustrations were added to the 1954 edition. I am not surprised to find that mine is this second edition since I find that people are always attracted to objects from the year of their birth. There are three prices inside the cover, all in pencil. Five shillings, then, underneath that, two shillings and sixpence. These old prices have both been crossed out. Underneath it says $\$ 20.00$, which I paid. I am amused that the value of the book fell and then rose. I consider disputing the price, but then I hear the bus coming so I pass over my $\$ 20.00$ note and run.

April 2011 was a strange time; six weeks or so had passed since the big earthquake, and still the whole place shook and wobbled. I was constantly trying to persuade my mother to leave the city because I thought it was so unsafe, but she was not seeing things the same way as me at all. Once she said that if she left, she did not think she would ever be able to return. I was struggling to understand why this was the most important factor in her decision, but it was.

A few people had left Christchurch but most, like my mother, had stayed and I could tell from what she said that everyone, including her, was terrified, although they didn't always say so. I could understand this fear too. 
It was impossible to ignore the constant rattling and rolling because it all happened so often, and it was impossible to ignore the knowledge that these same noises had killed people just a few weeks earlier.

I had begun to be quite preoccupied by the question of what was causing all these thousands of earthquakes and what was going to happen next, and, since the scientists sounded as bemused and anxious as everyone else, I felt myself unusually open to knowledge from other places. A giant catfish which, having escaped control of its minder, caused earthquakes by thrashing around under the city of Edo in the nineteenth century, caught my attention. That the intentions of a violent catfish seemed as reasonable an explanation for hundreds of earthquakes as anything else will, for anyone who knows me, speak clearly to my state of mind. 
Tidbits from Maori Tales of the Port Hills catch my eye. I add them to my ruminations.

Both the Port Hills and the mountains of Banks Peninsula are volcanic in origin. In Maori tradition, Cowan says, earthquakes and volcanoes are both caused by Ruamoko, son of Papatuanuku, the earth, and Ranginui, the sky, walking around under the world.

Perhaps the earthquakes are a sign that the volcanoes are becoming active again? There was talk of new warm-water springs at the foot of the hills.

A friend happened to mention Awarua-o-Porirua, a taniwha that had risen near Porirua, travelled north to Hawke's Bay and perhaps returned. Could a taniwha, which eats people and makes sandbanks and lakes with its tail, cause earthquakes, I wondered?

Perhaps right here, in Māori knowledge, I will find out why all this is happening, I thought, when, several weeks after buying the book, events recognisable as thoughts arrived. 
In late December 2011, on a visit to the first shops to re-open in the centre city, I took eight photographs. They show:

- Ballantynes Department Store Christmas window containing Red Riding Hood, the wolf, a crocodile, trees with faces; a scene that should look harmless, but doesn't;

- two buskers at the edge of the newly opened shopping area, beside a wire fence;

- a woman holding her camera up to a wire fence, taking a picture of Colombo Street, which is wide and empty;

- people standing by the fence, looking down a closedoff road;

- people holding their cameras up to take photographs over top of the fence;

- a wooden fence inside a wire fence, blocking entrance to a concrete parking building;

- Colombo Street, empty, looking up towards the square, with the wire fence in the foreground;

- the Bridge of Remembrance, access to the Bridge and Cashel Street blocked by a wire fence.

I have six semi-permanent impressions of Christchurch's Anglican Cathedral. The first is a photograph of my grandparents dressed for town, taken in front of the Cathedral by a street photographer in 1952, just before my grandfather died. The second is a photograph of me, aged twelve, dressed in what I hoped was a fashionable teenage style, taken in front of the Cathedral by a street photographer in 1966. The third is a photograph of the Cathedral spire, tilted at a crazy angle, taken by my son in 1993 with a disposable camera which I gave him to use on his first solo trip to stay with his grandparents.

The fourth is a simultaneous sense of belief and disbelief that a girl could mount an unnaturally tall horse from the balcony halfway up the spire, this image created by my father in bedtime stories he invented all by himself. 
The fifth is a smell, the old-wood-and-closed-space smell inside the winding staircase of the spire itself, a narrow and rather scary place where the steps had been worn away in the centre by all the feet which had climbed the spire; this image created by my own nose some time in my childhood.

These five impressions surprise me, as I had not thought of myself or my family as having any connection to the Anglican Cathedral.

The sixth is a memory of the Cathedral as I have seen it recently on television, broken down to the height of its window sills, a height at which it cannot present any risk to people working nearby. 
Christchurch 1962-64: as I remember it. The Port Hills were close. The Alps were far away. We were in-between. Sometimes my father went up the Port Hills in his red Morris Minor and we followed, as children do.

This is us at the Sign of the Takahe in 1962, walking around in the garden of a castle. I am waiting to see if something happens there, but nothing does. The driver of the number 10 bus sits in his bus, eating his sandwiches and reading the paper on his big steering wheel. I am surprised that there is a bus stop right outside the Sign of the Takahe. I thought it would be miles away from town, hidden by swirling mist, and I thought we would know what to do when we got there.

My father often talks about the Depression and he talks now about the men on relief who built the Sign of the Takahe and how wonderful the building is, considering that they had no tools and no money for materials, but all I can see and think about is mountains, so I look away.

This is us in the new road tunnel to Lyttelton in 1964, my father as proud of this clean light tunnel as if he had built it himself, talking while he drives about the First Four Ships and holidays he had as a child, at Port Levy.

The Four Avenues.

The Cathedral.

The first Settlers walked

over the hill

from Lyttelton

says the back of his head.

In the Museum, which I like a lot, there is a ship's cabin and inside the cabin is the family who lived there on their way over from England. There is also a shop full of tiny children's boots and a gallery of period dresses. 
I draw early and mid-Victorian ladies. I draw them on paper, their hair parted in the centre, with clusters of ringlets over their ears, or I draw them in three-quarter profile on the foggy car window, with long eyelashes, turned-up noses and little pointed chins. I draw their satin skirts, ruched and glistening. I draw tiny waists and bare white shoulders. I draw the toes of dainty boots, peeking out from under their skirts.

My second cousin Alex drives a car up the Summit Road and crashes. In The Press there is a photo of the car, lying upside down with its doors open, far below the road. The car looks like an insect. Maybe some of his friends were in the car too. Maybe the car was stolen. Maybe one of the other boys died and it was Alex's fault. I am not sure if I remember these things being said or not. Alex loses his left leg just below the hip. For a while there is talk of pain in the leg which has gone, and of the stump. Not much is said about how a boy of sixteen is supposed to get on with a pink plastic leg. From the kitchen in their state house I look down the long dark hall. At the end I see Alex sitting on his bed in his underpants. I know I shouldn't look. I see Aunty Maggie take the leg from where it stands in the corner beside the wardrobe and bend over the stump. There are buckles and straps on the artificial leg; I can see them. I know it hurts for Alex to wear the leg and I hear Aunty Maggie arguing with him, trying to persuade him to wear it. Uncle Jack sits all day with a flagon beside his chair, smoking and listening to the races, in the darkest corner of the lounge.

We lived in a suburb called Addington. We lived there because our family had always lived there, from the time when the first of them arrived from Ireland in 1912 and talked their way into jobs in the prison, the mental hospital and the railway workshops.

Addington was flat. Brown blinds pulled two-thirds of the way down the windows and six-foot-tall wooden fences kept the neighbours from seeing what you were doing. Only apple trees and clothes lines were higher than fences. 
On Friday nights, for fun, we would go into town. We would drive across the Bridge of Remembrance, which I liked. We would eat at a Chinese restaurant near High Street or perhaps at Fails Café or The Swiss Chalet, and then walk up to Whitcombe and Tombs for a browse around the books. Some nights we might go to Delano's Magic Shop in Chancery Lane, which my father liked, or down Press Lane. A job at The Press was given to a young person only after a meal with the Editor, in which table manners were critical, my father said. As we passed through the Square my parents would walk quickly past Cokers Hotel, where Uncle Jack worked as a night porter.

At school I learned about the Spartans who were fierce and brave and about Kupe, who discovered New Zealand. I also learned 'Maori stick games'. We were to roll up newspapers into baton shapes and sit in pairs on the floor facing each other with our legs apart, which meant arranging my dress so that it sat decorously on the floor. Then we were to bang the sticks on the floor and pass them to each other to the rhythm of a song in Maori.

I can still sing the song. The first two lines go like this:

Hoki-hoki tonu mai,

Te wairua o te tau.

No reason was ever given for singing this song and no one translated the words. I don't know if I even realised that these were words with meaning, like English words.

In 2011, from Maori Folk Tales of the Port Hills, I learned that the word in the second line is 'wairua' not 'waiuru' as it was sung at my school. According to Cowan, the words mean:

Return, return again to me, The spirit of my love. ${ }^{8}$

I can't remember if there were any Mãori children in the class and I can't remember whether I knew, as a child, that Māori people lived near Christchurch before it was Christchurch. 
The Museum had Maori fish-hooks and woven bags and cloaks and stuffed birds and maybe they had a meeting house or a canoe, but I never thought of these as local. I walked quickly past the birds and the fish-hooks and the cloaks on my way to the Victorian Street and the gallery of dresses.

This indifference, this knowing and not knowing, has been much commented upon as part of the flavour of Pākehā New Zealand, and in myself I find a precise example.

On 21 November 2012, I read about From Dust to Light, ${ }^{9}$ an album of songs in Māori and English, performed by Ariana Tikao. The album title comes from the image of dust rising over the city after the earthquakes, she says, and I think she means dust from demolition of all those buildings, this dust much talked of in 2011 and mentioned still in 2012. While making "Te Heke", one of the songs on the album, she held taonga from her tipuna, borrowed from Canterbury Museum, she says, an experience which she specifically mentions as a highlight.

Later, when I meet Ariana she corrects me on a few points. The dust she saw was not from demolition, as I had imagined. It rose seconds after the quake, on February 22, she says, as buildings fell. This immediate and transforming moment preserved by a quick-thinking photographer, and preserved again by Ariana in her album title and in her accuracy about the particular dust she saw.

She did not hold the taonga while writing the song "Te Heke", she says. She held the taonga while she made the video of the song "Te Heke". I am not sure what this distinction means, but I certainly notice that Ariana takes the trouble to correct what I said about this song and her holding of the taonga. I also notice a difference between the private moments of writing and the public intention of making a video. I look up 'heke' and find it has a number of meanings, one being a decline. 
In July 2011, I drove up to the Sign of the Takahe to look at it again. It turns out that the Sign of the Takahe is a fake castle, closed off now by a tall wire fence and Danger Keep Out tape. A notice on the door says that access is restricted by order of the Canterbury Earthquake Recovery Authority. From outside, the building looks mostly undamaged, although I have learned now that buildings that look mostly all right can turn out to be completely broken. Pieces from the decorative ramparts have fallen off and there are cracks showing where the next bits might fall. Some high bits are held in place with wooden braces and ropes. Hunks of stone have either fallen or been taken down and are stacked in the garden along with the outdoor furniture from the café that used to be inside.

An inscription is carved into the stone just beside the main entrance. I read it through the wire fence.

Cantanes licet esque minus

Metaldet eamus

The translation is underneath.

Let us march on singing ever

The road will tire us less

The wind up here is freezing cold and there are patches of dirty snow piled in the gutters but I see several pairs of women out for a walk, turning and heading further up the Summit Road. Groups of cyclists pass by, also bound for the Summit Road, and there is a family mucking about with mounted binoculars at the look-out. While I am there, wandering round and reading signs, a number 10 bus arrives and the bus driver takes out his lunchbox.

I see now that the best thing about the Sign of the Takahe is the view. On one side you look down over shimmering silver water towards the sea. That silver water with sandy islands is the estuary of the Heathcote River. On the other side, you look down over houses towards perfect fairy-tale mountains. 
From Maori Folk Tales of the Port Hills, I learn that the Heathcote River was originally called Opaawaho, which means 'the outer or seaward pa', or otherwise 'an outpost' ... .

'because of its situation, the outermost kainga of the plains and swamp dwellers, commanding the passage down the Heathcote to the sea ... Here it may be recalled that the hapu who lived where Christchurch city now stands were given a nickname by the outer tribes at Kaiapoi and elsewhere. They were called ' $O$ Roto-Repo', or more briefly, 'O-Roto-re', which means 'in the swamp' or 'swamp-dwellers'. They lived in a marshy region which had its compensations in the way of abundant food, for the swamps and creeks swarmed with eels and wild duck. ${ }^{10}$ 
Christchurch 1922. My grandmother, a newly married woman, lives in Barrington Street. Her husband, who learned to drive ambulances in the army, earns f3.10s. a week this year, five shillings less than in 1921, which has cut the money in her purse for bacon and tea and leaves him hardly any beer money. In order to have enough butter and eggs to make a sponge cake for her sisters' afternoon tea on a Sunday, she and her husband have bread and jam for pudding for three days. These are facts.

My grandfather works as a chauffeur for a wealthy and childless couple. My grandmother worked, until she was married, in the haberdashery section of Ballantynes, for £2.10s. a week. Now it is her husband's job to support her. They have recently been able to afford a bicycle, which he rides to work in Fendalton. These are also facts.

Here is the boundary of conjecture.

My grandfather says if they want to sleep together at Port Levy this year at Christmas they will have to buy a tent. My grandmother says yes, promises to put a bit extra away for the tent but doesn't tell him that her cousin Maggie will be sleeping with her in the tent, not him. Poor Maggie. At her father's beck and call since her mother died. And her only a wee girl, not long at school.

Christchurch 1922-1977. More facts. Maggie marries Jack because she has to. When he comes home on leave Jack looks carefully at Alex to see if there is any family resemblance. There is but not to him. Alex never really gets what school is about. He learns to climb into houses through the toilet window and steals from everyone, even family, and at sixteen loses his leg in that crash on the Port Hills. Alex never works.

Twice a week Maggie plays Housie at the Shirley Lodge. Maggie shows me how to play four cards at once, but I am never as good as she is. Maggie and I smoke Pall Malls. Even at fifty she is all glamour with her long red nails and her marcasite rings. 
Maggie likes to sit in the kitchen in the dark on Saturday nights, her transistor radio tuned in to the police frequency, listening to call-outs to fights at the neighbours' and maybe a mention of Alex. She never says, but I guess that's what we are waiting for. One night she tells me that gin makes women maudlin; we drink rum and coke.

Alex and his friends smoking dope and drinking rum and coke in a motel room in 1977. Me in that motel room for half an hour; leaving while I still could. 
Through the winter of 2011 tidbits from Maori Folk Tales of the Port Hills are still catching my eye. Sometimes I recognise a name or a place. But forests of 'purple prose' about the shape of hills and so forth cause me to shy away from Cowan's book for weeks at a time. After a certain period I decide to try again and this time I am more systematic. I start with the Preface.

Here Cowan describes his purpose in writing the book:

In this little book I have endeavoured to interweave with descriptions of the most picturesque parts of the Canterbury Port Hills some of the Maori poetic legends and historical traditions which belong to the range, and which have not previously been recorded. These stories, I hope, will invest with a new interest for many Canterbury pakehas the scenic beauties of the Port Hills now opened up from end to end by the Summit Road. ${ }^{11}$

Here, also, he describes his gratitude to three people; ' $\mathrm{Mr}$ Hone Taare Tikao, of Rapaki, the late Mr T.E. Green (Tame Kirini) of Tuahiwi, Kaiapoi and Mr H. G. Ell'.

Cowan describes Hone Taare Tikao, of Rapaki, as 'the principal narrator of the legends'. Tikao is, Cowan says, 'a Ngai-Tahu gentleman, whose uncommonly retentive memory is a storehouse of information on local history and who blends in himself the gifts of the folk-lorist and the genealogist. ${ }^{\prime 2}$

This respectful but rather sparse description of Tikao is supplemented by a much fuller description on page 36 , by which time the reader is more than halfway through the book.

The kaumatua of Rapaki, the pleasant-mannered greybeard, Hone Taare Tikao, a gentleman of true rangatira breeding and demeanor, is the best informed man of his tribe-remnant on the Peninsula and Port Hills history and legends and genealogical recitalswhakapapa in the Maori tongue. 
Tikao was born in Akaroa over seventy years ago. He is of the Ngati-irakehu hapu of the Ngai-tahu tribe, and he is descended by several lines from Te Rangiwhakaputa and other of the warrior chiefs who wrested the Whanga-raupo and the Whanga-roa (Akaroa is the modernised contraction) from the dusky men of the Ngati-mamoe. From his parents and from Paora Taki, a picturesque old rangatira who once was native assessor at Rapaki, and kindred people of the generation that has gone, he learned the history and legends of these parts. ${ }^{13}$

From other places I learn that Tikao's father and uncle were taken prisoner during the raid by Ngāti Toa in 1830. Both men survived and returned home. This same uncle signed the Treaty of Waitangi in 1848.

By the time he met Cowan, Tikao was an old man. In later life he had a moustache and a round face. As a younger man he had been active in Ngai Tahu land claims and in Te Kotahitanga, a movement for an independent Māori parliament. A photograph of him from this time shows him with a full beard and black shiny eyes. Tikao, when he became Cowan's informant, was said to have a 'lively intellect' and a 'willingness to fuse tradition with the modern world' ${ }^{14}$

Mr Green, who has a Māori name but is referred to by his English name, was a source of written material only, having died in 1917. His were complex stories of conquest, families, etiquette and food sources. They are referred to in the book but presented verbatim in longer form in the Appendix. Cowan makes no comment about his decision to place this material apart from, but close to, Tikao's information and in smaller print. I assume it is intended to be an alternative view to Tikao's.

Mr H.G. Ell, to whom Cowan devotes most space and about whom he waxes most eloquent in the Preface, made it his life's work to provide Christchurch residents with 'the priceless gift of free access to these grand tops of the Port Range'. 
His 'enthusiasm, prescience of vision and singleness of purpose in developing the Summit Road along this mountain park have properly earned him the admiration and the thanks of thousands of his fellow citizens who daily lift up their eyes to the hills and who find solace for town-tired body and brain'. ${ }^{15}$

After reading these acknowledgements and with some sense of who these men were and why Cowan wrote the book, I feel enough solid ground under my feet to begin reading again. This time, rather to my surprise, I find that nearly eighty years after Cowan and his generous 'Ngai Tahu gentleman' talked about these places, they are talking to me, a Pākehā with ties to Canterbury, about things I had never heard before, and I am listening.

A book can do that. It can seem, within a few years of its publication, to have failed in its work, or it can seem to have succeeded. It can rise into a particular type of reader's consciousness, fall away, float somewhere for decades and rise again into the consciousness of a new type of reader. It can continue its work for hundreds of years, long after anyone has stopped looking at its behaviour and its functions.

Sometimes, during this second reading, I put myself inside Cowan's head. His plan, I decide, is to tour the Port Hills by car with his guide, taking the Summit Road and other smaller tracks. He intends that the book itself will follow this idea of a tour of the hills. In my mind he hires a 1919 Model T Ford Sedan for his outings with Tikao, this being my idea of a car a writer might be able to afford to hire on a weekly basis. The car has glassed-in windows, which I think Cowan would appreciate, knowing that he was in his early fifties and also knowing how cold the wind can be up on the Port Hills.

I try to notice when significant moments come along, gradually realising that these moments are always direct quotations from Tikao. When Tikao speaks I leave Cowan's head, and I listen. 
One 'golden afternoon' when 'the hills were the hills of an artist's dream, all their asperities of crag and bare bluff softened and gilded by the mellow light of a calm bright windless day', ${ }^{16}$ Hone Taare Tikao tells Cowan about the Patupaiarehe, the fairies as Cowan calls them, 'whose castles defended by thick dark woods and fogs and mists, ringed the harbour and made the Peninsula an uncanny land, given to all manner of enchantments'. ${ }^{17}$

After discussing the fairies, Tikao lifts his arm and points. 'Over yonder, he says, 'are the chief pas of the Patu-paiarehe, which I shall list for you.'

I imagine Tikao pointing to each one as he speaks:

There is the rock of Te Pohue, which the pakehas call The Monument, between Purau and Port Levy; there is Hukuia Peak, on the road between Pidgeon Bay and Little River; there is the mountain-top of Te U-kura, which commands all the hill country of the Peninsulait is just at the back of the stopping place called Hilltop on the road from Little River to Akaroa town.

Also there are the high rocky peaks which overlook the Akaroa harbour-Pu-Waitaha, or French Hill, between Wainui settlement and Buchanan's; Otehore, a rocky flat-topped height above French Farm, on the upper part of the harbour; the summit peaks above Akaroa town, Purple Peak, Mount Berard and Brazenosethese we call O-te-Patatu, Tara-te-rehu, and Otoki; and lastly Tuhiraki, the sky-pencilling peak, which the French named Mount Bossu, on the western side of the harbour. All these were the mountain pas of the fairies. 18

I have a pleasant fantasy of a friendship between two men who respect each other. In my version, the two men spend the colder afternoons in a haze of pipe smoke beside Tikao's fire, Cowan asking questions about things he has missed and taking notes in his diary, in shorthand. A historian friend told me that Cowan used to take notes in shorthand, in Māori, so I add this detail to my picture. 
Afterwards, Cowan drives back to his lodgings. I borrow the word 'lodgings' from a time before I was born.

At night Cowan finds that Tikao's stories dance about in his mind. He sees the Maeroera with their long fingernails, bent over in the mud flats, looking for flounder.

He dreams of the Patu-paiarehe calling to Maori maidens as they walk through the trees, sees their half-breed children their light skins and fair hair proof of their fairy blood, whatever the mothers said; liminal experience clearly part of Cowan's life.

Tikao says to Cowan:

We are half Pakeha ourselves now, we Ngai-tahu he says, and our young people deride these notions about the Patu-paiarehe. Yet-these hills were different in my young days, when the mists came down and the fog enveloped the little streams tumbling down all the valleys from the gloomy places. We went birding into the forest, and we made clearings for cultivations and cut firewood in the bush for sale to the pakeha. Sometimes when the mists came down and the fog enveloped the hills, on still, calm days our old men and women would say the fairies were out, the sunshunning Patu-paiarehe, and it were well not to venture up the range. On brooding quiet days out people could hear the thin voices of the little folk - they were small, fair people, as all the elders said-crying out to each other and singing fairy songs and playing little songs on their wooden or bone flutes, their koauau and putorino. ${ }^{19}$

Cowan tells his readers what Tikao has told him:

The first people were the Hawea, the second the Rapuwai, the third the Waitaha and the fourth the Ngati-mamoe, whom the Ngai-Tahu dispossessed, in their turn to be supplanted by the white-skins with their bags of gold sovereigns and their land-sale deeds. ${ }^{20}$ 
In another book, where much more of him was visible, Tikao used his hand to show something that he knew: 'the palm representing the living side and the back of the hand the dead side, the soul apparently passing through at death. This was to show what a thin division divided life and death or separated this world from the next - the visible from the invisible. ${ }^{21}$ 
Last week I met an eminent American professor in his early sixties who told me that he thinks a lot about failure. People often die believing that their life has been a failure, he said, but the effects of the things a man does can take decades or even centuries to be seen.

His own life has every appearance of having been a success. He has written many books, his investments are diversified; his wife cares for him and he for her. He travels when he wants to and apart from high blood pressure, which is brought within normal limits by medication, he is in good health. Over lunch, surrounded by a table of noisy historians, the professor told me that he was introduced to the awareness of failure by his grandfather, a Polish Rebbe (spiritual leader) who died when the professor was a baby and left a letter for him to open when he was forty. The letter was in Yiddish, a language which the professor spoke at his mother's knee, but by the time he was forty, could no longer understand.

The letter called the man to certain mystical practices. In the letter his grandfather said that he chose forty for the opening of the letter because what he had to say could only be said to someone for whom the walls of grief had been breached. For some it happens earlier, the letter said, but by forty every man knows that death will come for him and for everyone he loves. Forty, the Rebbe said, is the start of the age of grief. In the age of grief a man begins to have compassion for other people's failures. The price of this compassion is that a man understands how he himself has failed.

The professor told me that he disagrees with his grandfather. Everyone thinks they have failed, he says. But in the long long picture, they turn out to have succeeded in ways they could never have imagined, and failed in ways to which they were completely blind.

The professor has not begun the study to which his grandfather called him. Instead, he has spent his working life asking why, at a particular time, some things are remembered and others not. 
He has developed a method of categorising silences, he said, smiling, this work bringing him into rancorous dispute with many academic colleagues early in his career, but these days allowing him to lunch, as an honoured guest, at a table of historians.

Shortly, he said, he intends to retire from teaching. He has specialised in the study of wars, he said, but in retirement, may branch out into other social questions. The exploitation and exhaustion of natural resources such as oil and minerals interests him, he says, and he believes there will soon be interest in this topic's silences. 
The professor's story of the letter in Yiddish made me think of Sarah Moskovitz, who spent several years translating a collection of poems in Yiddish into English. All the poems are part of the Ringelblum Archive, hidden in two milk cans and ten tin boxes inside the Warsaw Ghetto in the 1940s.

Sarah told The Temple Sinai Poetry Group about the existence of these poems in Wellington in 2011. She read some poems out loud to us in Yiddish and in English, and gave us all a booklet with pictures of one of the milk cans, Ringelblum the archivist, poets Yitzkhok Katzenelson and Miriam Ulinover, and a bunch of lilacs on the cover. 


\section{Small Antiques 22}

Once there were three girls as beautiful as gold,

Who bragged about the rare antiques each of them did hold;

"I have a flowered head scarf", the first said to the others -

"embroidered with cross stitches by my own grandmother."

"I have a jewelled needle", the second proudly stated-

"from my great grandmother with small diamonds decorated."

Only the third girl laughed silently with pride,

And quietly opened the door to an alcove inside;

"The dearest little antique of all, is mine alone, right here -

My great grandmother herself of more than a hundred years!" 
I remember it was a cheerless grey Sunday afternoon in April.

By the time Sarah had finished it was dark outside but through one window I could see three stars. The room where we met was dark too, except for a pool of yellow light as faint as though the room was lit by a single flame. At the time, and for a year or more afterwards, I believed that small light in the apartment in Wellington was the life of Europe's Jews, as expressed in Yiddish poetry.

I wrote a poem soon after that Sunday afternoon as a tribute to the poets of the milk can; milk cans heavy with associations for me long before that day.

My poem about the milk cans in the Warsaw Ghetto, strongly influenced by a poem by Miriam Ulinover about a grandmother completely unlike the grandmother she actually had, was as sweet as the smell of lilac. Even on the subject of hunger, sweetness lingered. I have thrown most of that poem away.

When faced with material from outside my own cultural background I am easily confused and make lots of mistakes about what is important. 
Inside the milk cans, minutes of the last meeting of the ghetto branch of PEN, a poem in which the poet fondly remembers his cold and hungry childhood, and a poem from Yitzkhok Katzenelson, written in the ghetto, this a small section:

Come, come embittered ones,

Lost and gone astray

On all the roads of the world,

Come, come trembling ones

Frozen with cold

Come with your own wells, come dear ones,

Come close to your source $-{ }^{23}$

the milk can standing here for something strong in which they could place parts of themselves, none of this to be interpreted any longer as hope.

In America, where a Jewish child could grow up safe and sound, a single milk can once held Houdini folded in three, Houdini standing here for the old culture; inside him his mother, her mother, the language they spoke, a recipe for borscht, plans for his own tombstone, pleasing memories of chorus girls and philanthropic intentions. The milk can standing here for containment and death, his usual adversaries, from which he expects, on any particular day, to escape by careful planning.

When I write about Houdini, a man who loved his mother more than any man ever had, a little sweetness remains, but when I write about the milk cans I know best, almost all sweetness is gone; and what little remains is a cliché. 
On a farm high up the Whanganui River, eight milk cans full of warm frothy milk sit in a shady trench covered with mānuka branches. Grass grows like a curse up here. A returned soldier with a dicky chest milks his twenty cows three times a day and still he can hardly keep up. His wife milks with him and cleans the cans. Sometimes they make love in the garden, magpies calling from the trees. Mutton chops and eggs after milking, cold meat for tea, bread one day and scones the next; roast mutton on Sunday; all gone by Wednesday. Plenty of milk and butter but lately milk won't sit on his stomach. Every second day the boat calls and takes the milk away to town.

Milk cans standing here for the mortgage which never changes, the falling price of land, warm sun and rain which makes the grass grow lush, the bush they have chopped and burned themselves and a day they talk about for years before it happens; the day they walk off the farm, with one horse and a suitcase.

No record of these years except the phrase They had to milk three times a day in family stories; and a possible match with a magpie sound heard across hills with no roads and a short stretch of sea.

I never believed that these people made love; I believe that they lay down together under a bright blue sky, near the vegetable patch, and heard magpies as they did what they needed to do with each other, a practical partnership in sex, not much different from one doing the baking and one bringing in the cows. 
Emanuel Ringelblum is a somewhat elusive figure, partly for the obvious reason that few people of his age who knew him well survived. He was known to have kept a sort of diary, full of stories of people he met in his work, and apparently without much mention of himself.

He was born in a small village called Bichuch (in Yiddish) in Eastern Galicia, then part of the Austro-Hungarian Empire and now in Ukraine. Bichuch, overlooked by an old and empty castle, was a place that you had to leave, as Jacob Freud, Sigmund's father, did to open a business in Vienna or, as Emanuel Ringelblum did, to attend university.

Although new to me, the Ringelblum Archive was not a totally new form of History-making. It was up to Jews, Ringelblum thought, to claim and protect their own past. Through the 1930s he worked in compiling documents of the Jewish small towns or shtetls of those times in order to construct a history for the future; a future in which he saw Jews and Poles in a complex but workable Poland.

The ghetto archive was much wider and deeper in scope than I first realised. It was assembled using explicit research guidelines Ringelblum had developed based on the particular form of Yiddishist and Marxist historical scholarship that he had been already been enacting.

As far as Ringelblum was concerned, nothing about the life of a community was unimportant.

Inside the ghetto Ringelblum gathered together a small group to raise money and decide what to collect. This list of topics to be researched is approximately three pages long and its main headings are:

Historical Overview (demographics, apartments, living conditions)

Economics

Social Help

Social and Cultural Life 
Polish Jewish Relations

Expellees and Refugees

Artists

Painters

Musicians

Daily Life of Workers, Artisans and Smugglers

The Jewish Child

Shops. ${ }^{24}$

All of the archive work was carried out in secret, with no one knowing more than he needed to carry out his particular task. There were three rules:

1. Collect material.

2. Gather impressions.

3. Write them all down immediately.

A group of 50 to 60 people worked actively on the project. They wrote accounts of events or their work, copied or typed documents and initiated surveys and other types of research. Apparently many of these people wrote on topics they chose themselves. Ringelblum preferred, if possible, not to use professional writers, because he wanted the accounts to be as simple and plain as possible.

He aimed for objectivity, although certain themes and loyalties shine through his list of topics and his method: his interest in ordinary Jewish people and his commitment to Yiddish, for example.

Ringelblum, who did not know, when he began the archive, how the Holocaust would end, saw the archive initially as an act of resistance to fascism as well as the construction of 'a useable past ${ }^{25}$ of Polish Jewish relationships and life, which he had always believed would continue. 
But news of events in Poland filtering back into the Warsaw Ghetto and deaths and deportations from the Ghetto pressed in on the archivists. The more I thought about this, the more I wondered how they continued; how they found the energy and will when it was already obvious that the act of recording could not save the archivists or anyone else?

One woman, Gustawa Jarecka, wrote of this in the archive.

The desire to write is as strong as the repugnance of words. We hate words because they too often have served as a cover for emptiness or meanness. We despise them for they pale in comparison with the emotion tormenting us. And yet in the past the word meant human dignity and was man's best possession, an instrument of communication between people. ${ }^{26}$

One man and two teenage boys were in charge of burying the first part of the archive under a school. In his last notes one of these young men talks about being unable to finish his schooling because his family was too poor. As he is about to run to his parents to see if they are alive, he writes his last words:

Remember, my name is Nahum Grzywacz. ${ }^{27}$

Ringelblum had no way of knowing the uses future historians would make of the Ringelblum Archive, which he referred to as 'the legend'. ${ }^{28}$ 'They can sort it out after the war,' Ringelblum told Hersh Wasser, the man in charge of burying the archive. 
I have since heard that Yiddish, the language which Jorge Semprún once mistook for the embodied voice of death never died in Melbourne. It was brought to Australia (again) after the war in the suitcases of refugees and is spoken in daily life by certain groups of Jews in Australia. In 2011 I went to an exhibition featuring Yiddish life in Melbourne. At the end of the exhibition, there was a noticeboard with this heading: 'Tell us what do you think is the future of Yiddish?' Paper and pens had been provided. On the day that I was there, there were only two notices on the board. One said 'Go Yinglish' and the other said 'I am not exactly sure'.

The poets. This one was shot by peasants acting under orders, and this one ended up in England.

Miriam Ulinover was last seen with her daughter, getting off the train at Auschwitz; everyone knew that inside her backpack she had two manuscripts; neither the woman nor her daughter survived and the manuscripts have not been recovered.

This one thought her lover had died, but he survived and he took to drink. Oh yes, one of us says, in this comfortable apartment in Wellington, that would have been caused by his experiences. Maybe, Sarah Moskovitz says, but we have our drunks too.

18 September, 1946: Ten tin boxes full of notices, essays, research studies, lists, menus, letters and every kind of description of life in the Warsaw Ghetto and what was happening to Jews in other parts of Poland were recovered that day because a man called Hersh (sometimes written Herz) Wasser knew that part of the archive was buried where the school at number 68 Nowolipiki Street used to be. Wasser was one of three people who were involved with assembling the Ringelblum Archive and survived the war. 
December 1950: Two milk cans containing poems were found during construction work. A third milk can, said by Wasser to contain the last part of the archive, has never been found despite a number of attempts. According to Wasser, this third milk can was buried under a house at 34 Swietojerska Street, a site now occupied by the Chinese Embassy in Warsaw.

The poems from the milk cans have been preserved on microfiche by the combined efforts of the Jewish Historical Institute of Poland and the United States Holocaust Memorial Museum.

Beginning in 2000, Sarah Traister Moskovitz translated 137 of these poems into English, drawn to do that, she says, by her family's attitude to the Yiddish language and by the loss of family members from Warsaw. Her husband has helped, guessing what the words were when water and rats had taken sections of the text. Her son has made a website for them ${ }^{30}$ and placed a video of Sarah speaking about the work of Miriam Ulinover on the internet, the combined efforts of this family another act of recovery.

Sarah told me recently that the poemsfromhell website has caught the attention of readers from Russia, India, Australia, Denmark and other places.

In the video Sarah speaks slowly, as she did to the Temple Sinai Poetry Group in Wellington in 2011, navigating the emotions of the poems and their context with apparent calm. Only when she shows the picture of one of the poems, eaten away more and more towards the end as the poet describes the destruction of the ghetto, does she almost falter.

Notes I wrote just after this meeting refer to a poem Sarah was afraid of - one she left till last. I don't know if this was something Sarah said or something I made up. If it is true that one poem scared her, I would like to know which poem that was. 
Christchurch, April 2011. Of course, there are rumours that there has been much more looting in the Red Zone than is being officially admitted, the lawyer in Christchurch said about my mother's two diamond rings, worth as much as a small new European car, which had been sitting on the workbench in a jeweller's shop in Cashel Mall at the time of the earthquake.

Then there was a silence.

There are rumours that it is the soldiers, he said.

Another silence.

There's such a lot of property in there at the moment and no one really knows who owns it, he said. Most people have turned out to be very honest, he said. But some haven't.

Realistically, I said, what do you think the chances are that my mother will get her rings back?

Nil, he said. You should make an insurance claim.

Sooo, I said, feeling free to speculate now that we had received our advice, what's to stop the jeweller from keeping the rings, not telling his insurance company he has them, and selling the stones in Amsterdam?

Nothing, the lawyer said. I think you should make a claim.

He didn't respond at all to my next suggestion that we could perhaps retain a member of a motorcycle gang to shake down the jeweller on our behalf. After a long silence he said, Let me know if you have any trouble with the insurance company.

Sometime in the 1980s my mother had inherited two rings.

A canny Scottish farming woman, doing very well, thank you, was the first owner of the rings. 
She was a big woman with strong hands. She wore them, one on each hand, to church on Christmas Day and when she went to the races.

She kept the rings, separated by cotton wool, in a round ivory box with a carved lid inside her wooden jewellery box on her dressing table which had been brought out from Scotland. Huge dark and shiny furniture. Carved edges. Solid brass handles. When she died, at the end of a good long life, she left the rings, along with her maiden name, to her daughters, who, when they died, left them to my mother. The huge dark furniture went somewhere else.

Himself, as she called him, had inherited one farm, and then he had four, and although he grumbled about the wharfies and the cost of shipping, over the years he made pretty fair prices on mutton and wool. In his fifties he became ill with a disease that caused unbearable pain. A long sea voyage was prescribed. That and morphine. Knowing he would never work again, he gave the farms to his sons, who lost them almost immediately.

My mother wasn't the sort of woman to go to church on Christmas Day or to the races, but for the sake of a farmer's wife from Palmerston and a Highland flower name, which had by then been lost in a sea of men's names, she would sometimes wear the rings. Mostly the rings lived in their ivory box with the carved lid, in her plain modern jewellery box on her plain modern dressing table, their value something of a worry.

With my father lying beside her in bed, big and warm like a bear, she didn't worry too much. But after he died she took them into town and, with a certain amount of formality, placed them in a safe deposit box at the Westpac Bank and there they stayed, in a cool dark box, for a decade or so, until, late in 2010, my mother received a letter from her insurance company, saying that the valuation on her rings was out of date. The value of precious stones and gold had been rising rapidly, the letter said, and she should have the rings revalued. Surely items in a safe deposit box in the vault of a bank could never be stolen, we said, around the table that summer. 
We thought this was quite funny. We did not consider that the building might become a pile of rubble.

My mother decided she should follow the advice of the insurance company and get the rings re-valued, but there was a problem. Over the years she had lost the key to the safe deposit box. Some months went by, during which we turned out every corner of her drawers and looked for the key to the safe deposit box, but we never found it. We did find a number of keys for which we could find no locks, but that was no help.

\section{February 2011}

My mother paid a locksmith to come to the bank, had a new key made for the safe deposit box, opened it, took out the rings in their ivory box and put the box in her purse. Then she walked down a couple of streets to the jeweller in Cashel Mall. I'm not sure why she took the rings to this particular jeweller.

\section{February 2011: Earthquake Day}

Our main concern was her, but her main concern was her house, her cat, and the fact that there was no power, water or sewage. I don't know when she first remembered the rings it might have been after a few days. It is also possible that she remembered them straight away and spoke about them, but for a few days I wasn't listening.

I do remember that we talked about them a few times during March. She would use that pragmatic tone. Oh yes, she would say, they are almost certainly gone, but it doesn't matter really. People have had such terrible things happen to them. Then we would discuss those terrible things.

As time went by our discussions changed a little. We would each say that the rings were lost. I would say they were lost in the same way as I might refer to the scent of honeysuckle in an English country garden before World War I. She would say that they were probably lost. It took me a few weeks to notice this difference, more time to realise that the person who 
should do something was me, and more time again to actually do anything.

In the meantime I attended a poetry reading at which a woman collapsed, took out a new mortgage and read books about sculptural representations of the Holocaust.

\section{Early March 2011}

I phoned the jeweller's shop in Cashel Mall. There was no reply. I pictured the phone ringing in the Red Zone. Perhaps there were other phones ringing? There was an email address in their advertisement in the Yellow Pages, so I emailed them.

Hello I don't know how things are with your people and your business - I hope you are all alive and unhurt, and that you might be reading emails. My mother (name) had 2 diamond rings in being valued on Feb 22. She has asked me to enquire about the rings. We assume they would be in your safe and that you can't access them. Could you please help us with any information on the rings? They aren't as important as people, but they are of sentimental as well as financial value to my mother who is in her eighties. It would be great to hear from you

Lynn

My email came back to me with a message saying the jeweller's inbox was full.

Mid-March 2011

My mother read an article in the Listener about frustrated businessmen who were unable to get in to their businesses in the Red Zone. Gerald (his real name), a jewellery valuer, also from Cashel Mall, was quoted. He found it hard to understand some business people, he said, taking a passive attitude, moaning about not being able to get in to their businesses, and meanwhile he had been in to his business three times. My mother thought Gerald might know something about the ring 
situation because his shop was near the jeweller. I thought that idea was a bit far-fetched, but said l'd try to contact him.

I looked up Gerald's name in the Yellow Pages, phoned his business and the call was re-directed to his cellphone which he answered. He told me he had been in to his business, got all his stock and computers, and had now moved his business into a new location in Papanui Road. I asked Gerald if he knew how I could contact the jeweller with my mother's rings. He didn't, but he thought perhaps he remembered valuing the sparkly old things. He told me he would check his records in case he still had them.

He phoned back the next day and told me he had valued the rings on the morning of 22 February and returned them to the jeweller at lunchtime. He also told me the jeweller's name was Ted (Gerald didn't know his surname) and he gave me Ted's home phone number.

Now there was a trail. My mother took the rings to the jeweller named Ted on 17 February. He sent one of the shop assistants with them to Gerald, the valuer across the road, on 18 February. Gerald took photographs of them and wrote up the new valuation on the morning of 22 February then he took the rings across the street, back to Ted the jeweller.

Then nothing.

2 April 2011

I reached Ted's wife. I asked her to ask him to phone me. He didn't. I reached him at home on the third try. I asked him if any of his staff had been killed or hurt in the quake. He said there were a few cuts and grazes, but nothing more serious. He had a broad Devon accent and a defeated air. I distrusted him instantly.

I explained the trail to him and asked him if he had any ideas about what might have happened to the rings. 
Were they in his safe? I asked, thinking of a business like the Mercedes factory where every step would be guided by a protocol that never varied. He told me that he was only the owner and did not actually work there, so he did not know how the rings would have been handled, and he had no idea where the rings would have been at the time of the earthquake. He had not been allowed in to his business. He also said that he might not be continuing in business. I felt as though I was trying to hold on to a small undomesticated animal. It was wriggling and its eyes were darting from side to side, looking for a dark hole it could run away into.

He said he would ask his staff if they remembered the rings and get back to me.

He didn't.

9 March 2011

I phoned Ted again. He repeated that he had not been in to his business and did not know anything about the property which was there at the time of the earthquake. He made no offer to keep in touch, so I said I would phone him weekly to see how things were progressing. I wanted to keep his mind on our problem.

\section{March 2011}

I rang Ted again. He prevaricated some more. Zone 12, he said, as if that was important. The closest he had been to his shop was the fence. Etc. Etc. At one stage he began a vivid description of the minutes straight after the quake.

He and all the staff scrabbling around in the broken glass and bricks picking up whatever jewellery they could lay their hands on, taking it down to the basement where they had a wall safe. Power off, the basement in total darkness, aftershocks and sirens and people screaming. 
These were the first things he said which I believed.

They shoved, that was his word, shoved, whatever they had in their hands into the safe, but they were only able to lock one of its two locks. After that, he said, the police came and made them leave the building.

I was at a loss to know how to do any more for my mother, who, I now realised, felt guilty that, after three generations, the rings had been lost on her watch. Those were her words. My partner and I talked about options. Could you phone the police if you suspected someone of an intention to commit a crime? We thought not. What if Ted was not dishonest - just useless? Looking at this now, I see that a month went by in this phase. I can think of no reason why so much time passed, when the next step is so obvious.

28 April 2011

I emailed my mother's solicitor for advice. I thought that a lawyer who was doing business in Christchurch would have more of a feel for what was going on than a lawyer from Paraparaumu.

\section{Good morning Kerry}

I have made a time to talk with you tomorrow, April 29 at 2.30 about the best way for us to proceed regarding two diamond rings that belong to my mother and are missing in the earthquake. The rings were at $X$ Jewellers being valued on Feb 22. There is no dispute about that. The rings are antiques, with sentimental value as well as a joint insured value of more than $\$ 50,000$.

My mother has asked me to help her to recover the rings, if at all possible. At this stage, I am uneasy about the attitude of Ted $X$, the business owner, having found him evasive at best and probably lying once that I am aware of.

I wonder if Ted is making any reasonable effort to locate the rings and what the standard operating 
procedure would have been for handling rings like this would they always be put into a safe on return from valuation? And therefore what the chances are of recovering them from the safe?

And I wonder what is to stop a business owner in this situation from claiming from his insurance, leaving my mother to claim from her insurance, and recovering the rings himself?

I imagine the building will soon be demoslished.(sic) Once that happens there is no further chamce (sic) to reciver (sic) the rings, so there is possibly some urgency.

I have tried to engage Ted in discussion about the recovery of the rings but he is not helpful. I have also left a message for the other owner, $\mathrm{Mr} \mathrm{B}$, (17/04/11) asking him to contact me and have not had a response.

I would like advice about what to do next. I imagine there are lots of situations a bit like this in Christchurch.

Lynn 
In May 2011 there was a story that a vagrant was living in the Grand Chancellor Hotel in Christchurch, eating the food and drinking the drinks left behind in twenty-six stories of minibars and following the sun around the building to keep warm. The man was easily spotted by police as a mobile red shape on infra-red thermal imaging equipment, the building itself having reached the ambient temperature of Christchurch in May.

The building, supported with truckloads of concrete while complex negotiations were going on about who would pay for demolition, was on a clear lean, moving visibly in every aftershock. Many of its windows were broken, curtains flapped in the wind and there were stories in the paper of expensive belongings people had left behind in the panic of evacuating the building.

I heard earnest conversations about how the man could have got past the cordon and whether he had been homeless before the earthquake or not, the answer to this last question apparently making a huge difference to the whole situation. 
At this time I was reading books about how to find people who have disappeared. There are quite a few of these too, also mostly written by Americans. These books are the mirror image of the books about how to disappear. They use many of the same chapter headings. It's still all about information, finding all the trails a person leaves, tricking people into giving information to you when they shouldn't. The difference is in the tone. Books on how to disappear are serious; books on how to find someone speak of this as a game. 
Ted phones. He has been allowed in to his business for fifteen minutes, during which time he has retrieved my mother's rings, which he is now keen to hand over to us. I ask him to keep them until I am next down in Christchurch, on 23 May. He agrees. I am to phone him when I arrive in Christchurch.

24 May 2011

I phone Ted to arrange the handover. He suggests that we meet him at $7 \mathrm{pm}$ the next evening, in the car park of a disused garden centre in Marshlands Road. I say no to the garden centre car park in the dark. I suggest we meet at a BP petrol station near the garden centre which I assume will be better lit and have more people around. He agrees. Don't forget, he says, there is a charge of $\$ 175$ for the valuation. Bring a cheque made out to $X$ Jewellers.

25 May 2011

$11.00 \mathrm{am}$

I ask my mother if she would rather stay home while I go get the rings, but she says no, she wouldn't dream of letting me go by myself.

$2 \mathrm{pm}$

We drive out to the BP station, work out the direction he will come from and where we can park and watch who is coming and going.

$5 \mathrm{pm}$

We put two torches in the car, one with a big heavy handle. We tell two other people where we are going and instruct them to call the police if we are not home by $9 \mathrm{pm}$. Down the phone from Raumati, my partner hums the Harry Lime theme.

\section{$6.45 \mathrm{pm}$}

We arrive at the BP station fifteen minutes early. I park and we begin surveillance. 
After a while we see one car with a woman driver pull up. I write down its number plate. Then another car, and another, each with a woman driver. I write down all the number plates because when someone finds our car and our battered bodies, the number plates will help them find who did it. Then, about 7.07 pm, Ted pulls up in an old grey Toyota Corolla. I know it's him because I had asked him what sort of car he drove. We stay in the shadows, watching what is happening. A little pattern emerges. A woman gets out of her car and approaches Ted's car. He gets out and they walk to the rear of his car. In the red light of his tail light, he gets a package out of the boot, unwraps it, shows the woman something, she signs a piece of paper and goes back to her car. She drives off. After the third woman has driven off, I drive our car up behind Ted's car and leave the lights on. We wait.

He comes over to the driver's window. Lynn? he says. I introduce my mother and myself. Is it OK if I get in the car, he asks? Yes, I say, and he gets into the back seat. I turn the inside car light on. He could easily hit me on the head from behind, and I should have thought of that but now it is too late.

He gets out an envelope. This is the valuation, he says. He hands us photographs of the rings. We hand him the cheque. I get out the big torch and shine it on the photographs. He gets a package out of his pocket, unwraps it and holds two ring boxes out to my mother. We open the boxes and compare each ring with the photograph. I ask my mother if she is satisfied that these are her rings. She says yes.

Ted hands her a piece of notepad paper with 'I acknowledge receipt of my rings' written in ball point pen. Sign here please, he says. My mother signs.

Ted sighs and folds over somehow. When he starts talking it's all about insurance. You take out insurance and you think you've got yourself covered for everything, he says, and then when something like this happens, you realise that there is so much that you never even thought about. It's all just business he says. If they have four billion in claims and they can hold 
onto that money for an extra couple of weeks even, the interest on that is probably the size of my whole claim.

The insurance company is keeping him waiting, he says. He phones them every week and each time he talks to a different person. They won't say whether they will be paying him out. He thinks they are too scared to tell him the decision. He wants them to pay him out for a total loss, he says, but they want to set him up in new premises because that is cheaper for them. If they investigate you, and they find that you needed money before the earthquake, they won't pay out, he says. I wonder if the jewellery shop in Cashel Mall was in trouble. I am trying to think of a way to ask that, but by then my mother has had enough of the ancient mariner's story, and she dismisses him rather firmly.

We drive home across the city in the dark. There aren't many of us on the road. To my right, as we drive down Fitzgerald Avenue, I see the Red Zone. Actually I do not see anything. The centre of the city is as dark as the inside of a cow.

Postscript: Discussion continues in the family about where the rings will be safe. In the meantime, while we decide, I have sown them into the hem of my winter coat, an idea which floated up into my mind from somewhere. 
In our country and in this time, if a person disappears, you can 'report' the person 'missing', which means that the police will help you to find the person. They do this in a number of ways, one of which involves the use of specialist 'Search and Rescue' teams. I am very interested in these teams, curious about why people decide to do this work, and why a country like New Zealand, with its constant pressure to keep government costs down, is prepared to pay large sums of money to fetch back human beings who have drifted, or even marched, away from the pack.

I am surprised and a bit embarrassed to say that I have had more than one experience of someone seeming to disappear on my watch. In one of these situations I called the police to ask for help, but only after someone told me to. Unquestionably these experiences have sharpened my interest in departures, searches and rescues.

In the interests of perspective, I will add here that more than ninety-five per cent of people who are reported missing are found within a few days. Most commonly, missing people are found in a place with special meaning for them, often a place of peace and rest, and most commonly, although not always, they return or are returned, unharmed. Of the remaining 5 per cent who do not return unharmed, some will have disappeared without meaning to; the whole thing making sense later when the person is found and the circumstances revealed. The missing person may have fallen, injured his legs and feet, had severe stomach pain or been unable to move because of a heart attack, some of these circumstances more life-threatening than others. A person who takes himself away to commit suicide, however, is reasonably likely to die.

I did not know any of these things at the time I called the police. 
That Sunday morning I knew only that losing a person is like losing your keys. You try to find them by remembering the last few things you did with them and sometimes that works. But sometimes all it does is leave you with a hole in your vision. In that hole there is nothing.

I told the policeman about the fight. I told him that you had been gone a Sunday-morning-sized piece of time, and that having carried out a grid search of the neighbourhood and my conscience, I was sure you had left. I told him that you might have gone to the shop for a paper, seen an empty big green bus stopping, and decided to catch that bus. I did not tell him that I could imagine you walking into the sea and I did not tell him that the words 'called away', in my handwriting, had appeared on a piece of paper beside my bed a few days earlier. I did not want him to think badly of me.

He asked me what you had been wearing that day.

I told him that when I woke up, there was silence. There was also an empty teacup upside down on the bench.

He asked me if you had any identifying features.

I told him that yesterday I cut your hair with clippers while you sat on a chair on the lawn. I told him that you chose number 2 because the comb for number 3 was broken. I told him I rubbed your head in circles, pretending to look for hairs that I had missed.

He asked me if I had any friends or family I could call.

He asked me to sit down. That's when I realised that he knew where you were.

Floating in a pool of blue light was the husk of a man, watched over by a woman with tired eyes who said her name was Louise. The man was naked. A tag on his arm said 'Anon'. Louise asked if this was you. As much as this was anyone, it was you, I said. That was good enough for her. She changed the tag on your arm.

Louise spoke with great calm. Most people think the best thing is for someone who is loved to come straight back to their life, because they are missed, but that is wrong. 
It is a problem of time, she said, and of fate. When someone has been called away, they have been called away, and they should stay away until their fate catches up with them.

When the men found you, she said, you tried to fight them off with your long thin arms. So they backed off for a moment and did what they did whenever they didn't know what to do; they thought of their own lives and their fathers' lives. That's how they came to the idea that a grey-haired man might feel as if he were a boy again, lying still on the grass in the Sunday morning sun.

They were not sure that you wanted to be found, Louise said, so they sent you and your fate away together for a while to sort things out. It seemed best for everyone. Louise consulted her notes. She told me the name of the park where the men had found you. She asked me if the name meant anything? I said it was your favourite park.

The ventilator lifted your chest in perfect time. Waves passed and re-passed on a screen above your head. Louise said I could sit beside you. I reached under the sheet and took your chilled hand. Louise said I was welcome to talk to you, although no one knew where the words would go. She did not know exactly where you were, she said, or whether there was a sound connection between there and here. That's when I realised that you must be further away than the top of Mount Everest, because a dying man was able to call his wife by satellite phone from there to say goodbye.

Louise walked in circles around your bed, speaking softly to herself in single words. When I asked her what these words meant, she said each was the name of a substance you needed to have on board. I pictured you dark in the water like a wooden canoe, lifted and set down by deep ocean swells. 
Your eyes were closed. Light would be flickering through your eyelids. The shadow of an albatross. Blue and blue and blue. I knew then that you were travelling alone across a sea so wide that you might never come ashore.

I held your hand and kissed you. I felt a wild urge to tell you to come back. That everything would be all right. But I whispered only true things in your ear.

I don't know where you are, I said. But I am here.

One morning, which seemed no different from the ones before, Louise said it was time to see if you would come back. It would not be easy, she said. It would be a test of your will.

What ending are you looking for? I said, in your ear. There are places where the water rises into the shape of a mouth, I said. Whole canoes have been sucked under in these places. If you want to find land, you must open your eyes now and read the waves. Look for where the sea turns brown with earth washed out from a river mouth, I said. Search for shore birds. You will see many canoes passing and re-passing - these people are all watching you. Some of them are waiting to guide you in. Others are just interested in what you will do.

I saw a tree trunk floating just under the surface, dark in the water like a whale, you said, on your first day back. Then, as I came closer, I saw two canoes lying silent and motionless in the water near a river mouth. Each canoe had a man inside. One man gave no sign of seeing me. The other pointed to the shore.

Last night the wall at the foot of my bed ran with writing in all the old languages and I knew what all the signs meant, you said on your second day back, seeming to draw strength from this.

After you came back you were, for a time, an object of interest among our friends and acquaintances. Did you see white light? asked a friend with cancer. No, you said. It was just as if a light was switched off. Were there any warning signs? asked a friend with high cholesterol. Yes, you said, there were a few, but you put them out of your mind. 
I have also experienced the half-disappearance and reappearance of a friend. His was a DIY disappearance, without the benefit of any books or paid consultants. At the time I lost track of him he lived in Grey Lynn, with a woman he told me was the love of his life. Later he said that she was an alcoholic and that he had tried everything to keep her happy. He left the woman, his job, his friends and his flat and went to South Auckland, where he got a job driving a truck that picked up wheelie bins. He didn't change his name and he didn't set up any complex systems of mail forwarding or disguised internet addresses. He just left, and for three years, during his mid-forties, he didn't make contact with me or anyone from his old life.

Another friend and I used to meet in cafés and after we had drunk two coffees and eaten sweet cake, we would poke our tongues into the hole of the disappearance. He's the sort of person who could end up with his kneecap shot to smithereens, I would say, thinking of his fascination with Colombian drug cartels.

At times, after he came back, my friend would talk about what happened. We used to talk every few weeks in those days - I never liked to leave it too long in case he disappeared again. Some days we would just talk about everyday stuff but other times he would come back to his point of departure, each time describing what happened in a different way.

It was strange, he said, but he didn't really remember how the idea started. He didn't remember finding it in a book, or noticing it in his path. He didn't remember how it moved towards him either. One day it was just there, in the front of his mind, all sharp edges and promises. All he had to do was accept it into his body. He breathed in. Straight away he felt it moving in his stomach. Each time he breathed out he felt that he was tolerating its presence a little bit better and within half an hour he noticed that he was comforted by its influence and pleasantly curious about what would happen next.

The first thing he had to actually do was work out where he would go. That wasn't hard either. He had always belonged to 
two classes, the way some people have two nationalities, so he figured he would just return to something you did with your back. He wouldn't have to leave the country or steal the identity of any dead babies. He would just trade on the reluctance of his friends to leave the southern motorway.

One day, when I asked him outright what had made him decide to do this, he said it was a phase transition. 'When water turns into steam, that is phase transition,' he said. He also talked about old barns and the specific greens and golds of lichen. He advised me to spend a whole autumn afternoon, as he had once done, watching a wooden barn. For all sorts of reasons I didn't do what he suggested, but when I read Sebald's description of flowers growing over the ruins of a German town, I thought I had started to understand what he had seen one day in some warm paddock. I haven't yet been able to make any connection between water turning into steam under pressure of heat and the gentle subsidence of a wooden barn.

My friend came back because his brothers needed him, but in some ways he has only half re-appeared. Twice in the last couple of years he has spoken about leaving the life he has now and living somewhere warm by the beach. He would work as a barman he says, finish reading the Western canon and eat fish he caught himself. There is never any mention of other people in his disappearing plans, although one day he said to me again that he thought there was perhaps something missing in him. He had noticed it all his life, he said, this feeling that there was something he couldn't name, which everyone else could do and he couldn't.

I would be lying if I said that everything was down to her and the booze, he said one day. The booze took away someone I loved; someone who was, at the beginning, a comfort to me. But there were other things happening too. There was the job for one. It was fine getting the job. As usual I had papered over a few awkward patches in my CV because I thought I definitely had the skills they needed, or close enough that I could wing it. So then I had the job. 
I was writing some pretty good copy. I had a handle on the accounts I was given and I put in the hours. I drank with the partners whenever there was a new deal to celebrate.

No one said anything bad to me. They kept paying me and my name kept appearing on staff lists, but somehow the idea of me as a part of things just didn't ring true. I would wake up in the night thinking about how they spoke to me in a different voice from the one they used with everyone else. How the boss's eyes never met mine. How no one ever picked up on what I said when we were having morning tea.

I thought it would be different this time, but it wasn't, he said.

I remember when I went to university. I had a Bursary, but I failed everything. I went to lectures and wrote essays. The books I was reading changed my life. I thought I was doing what everyone else was doing, but obviously I wasn't, because they passed and I didn't.

The thing is, a life is supposed be lived on bedrock and mine isn't. That leads to certain recurring patterns.

Last time we spoke he told me he had moved to Christchurch where he had a job in PR for a property development firm. Apparently the company expects to make a killing in the rebuild and he plans to use his writing ability to help them do this. According to him, business in Christchurch is flourishing now as long as you know how to play it. 
Notes:

${ }^{1}$ Marx, Karl, and Friedrich Engels. 1848. The Communist Manifesto. Trans. Samuel Moore. London: Orion Books. 1996. Print. 55.

${ }^{2}$ Op. cit. 2.

${ }^{3}$ Swiggs. "Demolition of heritage buildings." www.rebuildchristchurch.co.nz/blog. n.p. 15 Mar. 2011. Web. 29 August 2011. The discussion is no longer able to be accessed.

${ }^{4}$ Wells, H. G. Russia in the Shadows. London: Hodder and Stoughton Limited, n.d. Print. 53-54.

${ }^{5}$ Op. cit. $141-142$.

${ }^{6}$ Op. cit. 138.

${ }^{7}$ Op. cit. 52.

${ }^{8}$ Cowan, James. Maori Folk Tales of the Port Hills. 1923. Christchurch: Whitcombe and Tombs Limited, 1954. Print. 44.

${ }^{9}$ Tikao, Ariana. "From Dust to Light." Ode Records, 2012. CD.

${ }^{10}$ Cowan 21-22.

11 Op. cit. Preface.

12 Ibid.

${ }^{13}$ Cowan 36.

${ }^{14}$ O'Regan, Tipene. "Tikao, Hone Taare - Biography."www.Te Ara.govt.nz. n.p. 1 Sept. 2010. Web. 3 Sept. 2011.

${ }^{15}$ Cowan Preface.

${ }^{16}$ Op. cit. 53

${ }^{17}$ Op. cit. 54.

${ }^{18}$ Op. cit. 55

${ }^{19}$ Op. cit. 54.

${ }^{20}$ Op. cit. 37. 
${ }^{21}$ Beattie, Herries. Tikao Talks: Traditions and Tales of the Canterbury Maoris as Told by Teone Taare Tikao. Wellington: A.H.\& A.W. Reed, 1939. Print. 36.

22 Ulinover, Miriam. "Small Antiques." (1922) Trans. Sarah Traister Moskovitz. poetryinhell.org. n.p. n.d. Web. 16 Oct. 2012.

${ }^{23}$ Katznelson, Yitzkhok. "Introduction to an Evening of Tanakh." (26 Nov. 1940) Trans. Sarah Traister Moskovitz. poetryinhell.org. n.p., n.d. Web. 16 Oct. 2012.

${ }^{24}$ Kassow, Samuel D. Who Will Write Our History? Rediscovering a Hidden Archive from the Warsaw Ghetto. New York: Vintage Books, 2009. Print. Appendix B. "Guidelines for a Study of the Warsaw Ghetto" 393-395.

${ }^{25}$ Op. cit. 12.

${ }^{26}$ Op. cit. 6.

${ }^{27}$ Op. cit. 4.

${ }^{28}$ Op. cit. 2.

${ }^{29}$ Op. cit. 13.

${ }^{30}$ poetryinhell.org. n.p., n.d. Web. 16 Oct. 2012. 
Part Three: Cairn

Rambly prose format 


\author{
Horse Lewis \\ Long George \\ Bill the Steward \\ Bloody Jack \\ Worser Heberley \\ Black Murray \\ Flash Bill \\ Gypsy Smith \\ French Jim \\ Johnny Jones \\ Long Bob \\ Butcher Nott \\ Fat Jackson \\ Geordie Young \\ Geordie Bolts ${ }^{1}$
}

I believe that lists of any sort have greater significance than is, at first, visible. After reading this list, a friend pointed out that Worser Heberley is one of her ancestors. At that moment and not a second before, I thought of him as a man.

This afternoon I have seen a photograph of James 'Worser' Heberley with his wife, Maata Te Naihi Te Owai, also called Te Wai Nahi. From now on I will always think of him as an older man, standing beside her with a worried look on his face. She is seated. He rests his arm on top of hers and wraps her hand in his. She looks straight at the camera, her expression unreadable.

I feel a weight upon my line no hapuku is here

but a weight of history swimming up into the summer air. ${ }^{2}$

\footnotetext{
${ }^{1}$ Macmorran, Barbara. In View of Kapiti. Palmerston North, N.Z.: The Dunmore Press, 1977. Print. 46.

${ }^{2}$ Wedde, Ian. "The Ballad of Worser Heberley." Sport 9 (1992). Print. 11-15.
} 


\section{Looking back from the Island}

This morning I was shopping in McLean Street, Paraparaumu Beach. The night before I had been reading about a whaling station near a pa called Te Urihi, ${ }^{3}$ which used to be at the mouth of the Tikotu Stream, where the skate-park and the public toilets are now. The author didn't say when the village and its people disappeared or how but she did say that in the 1920s Tikotu Stream was diverted to allow development at Paraparaumu Beach and now runs underground through concrete pipes, as Number Two Drain. ${ }^{4}$

With this knowledge, I start to imagine a stream you could drink from and a whaling settlement in that place. In fact, driving along the coast this morning I thought I would glance up from the road and see wooden ships with tall sails. Maybe even ships with eight guns, like the Tory, which, on 16 October 1839 anchored at Kāpiti Island, before sending a small boat over to inspect the field of a battle near Te Urihi. A nor'wester probably blew that day as it does most days in October. The boat party from the Tory walked north from Te Urihi to the mouth of the Waikanae River. Five hundred men women and children lived beside the river at Kenakena, surrounded by a mile of stockades. Surgeons from the Tory worked for several hours extracting bullets, binding wounds and setting broken bones. When I first read this account, part of me wondered vaguely why there would be more than one surgeon on a small ship in a small corner of the world, but another part of me felt warmed by this description of kindly men intent on healing the wounds of strangers.

Later I found that the Tory was here with a purpose. Wakahuia Carkeek, a descendant of Te Rangihaeata, Te Rauparaha's nephew, describes the Tory as 'sailing round the coast looking for suitable land [to buy]'. The Tory, he reports, was said to be 'carrying much merchandise as payment' and the Pakeha on board were 'keen to trade'. ${ }^{5}$ He describes the disputes that began immediately after the Tory left in a chapter of his book, under the title "The Problem of Land".

Barbara Macmorran, a great-granddaughter of Octavius Hadfield, tells us the Tory was 111 feet long and 27 feet 'in beam' and was 'run on man-of-war lines'. She names the captain and the other passengers, including two surgeons and one naturalist and doctor. ${ }^{6}$ She says that the vessel came here, bringing Colonel William Wakefield, 'to buy land for his brother Edward Gibbon Wakefield's New Zealand Company colonists, the first of whom were well on the way to New Zealand before the Tory ever dropped anchor in Queen Charlotte Sound'. 7

\footnotetext{
3 Macmorran's spelling.

${ }^{4}$ Macmorran 43.

${ }^{5}$ Carkeek, Wakahuia W. The Kapiti Coast: Maori History and Place Names of the Paekakariki-Otaki District. 2nd ed. Auckland: Reed Books, 1967. Print. 95.

${ }^{6}$ Macmorran 41.

${ }^{7}$ lbid.
} 
Although she describes land sales by Te Rauparaha and consequent disputes in some detail, Macmorran does not single out the sale or loss of land by Māori as a theme, either as a chapter heading or in the Index to her book.

A friend and I walked to the Waikanae river mouth last weekend. In the river right near the sea there are several small islands. We looked for a place big enough for five hundred people to live and we talked about whether the shapes of the islands, the wide flat channel and the smaller ribbons of water crossing the sand at the beach would have changed much in 170 years. Down on the beach that day a gale was blowing from the north-west. News of this wind had drawn kite-sailors from near and far. We stood for a long time watching these men who seemed to be standing on the water, joined invisibly to their sails, which were as brightly coloured as butterflies.

These days the ferry to Kāpiti Island leaves from Paraparaumu Beach, about a kilometre north of the site of the village of Te Uruhi. ${ }^{8}$ At the end of January 2012, in the dying hours of a nor'wester which had turned the sea brown and made waves as high as a fence, I crossed to the Island with twenty other people including a woman from Mexico who works as an environmental advisor to a German company which is trying to set up a coal mine on the West Coast, her mother who spoke only Spanish, a chef from Otaki and two beautiful Japanese women who were on a summer holiday. Looking back from the Island towards the mainland through binoculars mounted on a stand, we saw two men in a fishing dinghy in the distance. They seemed to be putting out cray pots.

Writing in a diary she kept between 1924 and 1942, Mrs Amy Wilkinson, the wife of the custodian of the Kapiti Island Bird Sanctuary, speaks of summer fires.

February brings with it a feeling that summer with its long days is slipping, slipping away. The heyday of summer time has passed and left behind a parched hot worldour little world-dim with smoke drifting over to the Island from devouring bush fires on the mainland. As the mainland bush is demolished the birds retreat further and further, their numbers lessened. . Y Year by year the destruction goes on, as more and yet more land is required for settlement. ${ }^{9}$

\footnotetext{
${ }^{8}$ Carkeek's spelling.

${ }^{9}$ Wilkinson, Amy K. Kapiti Diary. Ed. R. H. D. Stidolph. Masterton, N.Z.: Masterton Printing Co. Ltd., 1957. Print. 29.
} 
After Mrs Amy Wilkinson died, her son-in-law decided to publish her diary as a book despite not being sure whether she had written the diary with the intention of publishing it. He was driven, he says, by a feeling that it would be a loss to people who like to read about wildlife if her notes were not published. His decision, he tells us, has the blessing of Mrs Wilkinson's husband and their two daughters.

I am grateful to him for publishing this book, and to the family for allowing it, but 55 years later, I wish he had said a little more about how he decided what to include and what to leave out as he reduced eighteen years to 165 pages, one Appendix which records the date of sightings of the Shining Cuckoo and the Long-Tailed Cuckoo, and a two-page Index. Most of all I wish he had included dates beside the excerpts which he selected for the book. I want to know if she saw a morepork in her kitchen on Kristallnacht or thought she heard the voices of women and girls singing, or something else I could read as an omen. And what the sky looked like on 27 November 1935, the night the first Labour government of New Zealand was elected.

On the Island, in the summer of 2012, we had a guide who said that she could talk about animals or plants or history, whichever we requested. I chose history, which was a minority choice, so most of the time, as we walked around the north end of the Island, she pointed to trees, named them and helped us to spot birds in the branches or skinks, which liked to live inside boxes used to trap stoats, and were apparently undisturbed by blocks of blue poison several times larger than their bodies. At one particular place we walked slightly downhill along a path into denser bush with a dark canopy overhead. It was a little like walking into a tunnel. As I entered this shady place, I felt something which I can only describe as a separate darkness. I walked on, saying nothing about this feeling.

A little further on the guide stopped and told us this story:

At dawn one day, spotters on the Island saw hundreds of canoes leave from Waikanae and Otaki and row towards them. The water was dark with canoes so they knew a battle was coming.

Carkeek $^{10}$ gives a different account of how the people on the Island were warned of the coming battle. ${ }^{11}$ He says there were four warnings before the day the water was dark with canoes.

\footnotetext{
${ }^{10}$ Carkeek 34-35.

${ }^{11}$ According to Carkeek, this battle has three names: Waiorua, Whakapaetai and Te Umupakaroa.
} 
The first warning was given by a party from Kāpiti fishing for hāpuku from canoes. Seeing another group on the water and mistaking this for a war party, they rushed back to Kāpiti to warn of an attack. After several days had passed and there was no sign of the attack, another food-gathering party crossed from Kāpiti to Paekakariki to gather shellfish and karaka berries. At night, while they were collecting mussels, a war party surprised them and killed three people before the survivors could escape back to Kāpiti. This killing was the second warning.

A week or two passed. One night two of Te Rauparaha's children had climbed a tall tree, looked out towards the mainland and saw hundreds of flickering campfires. Those fires were the third warning. It is said that later that same night a man from the war party crossed to Kāpiti and told the people on the Island when and how the attack would be launched. That was the fourth warning. That man crossed back and joined the canoes in their early morning attack.

Both the guide on the Island that day in January 2012 and Wakahuia Carkeek, speaking from 1967, say that Te Rauparaha and his men on the Island defeated this army of perhaps 2000 men on flat land near the lagoon at the northern end of the Island.

Carkeek also tells of Hinewaioro, a woman who swam out to one of the canoes and captured a man she desired for a husband, and her father, who killed the 'handsome and willing prize'. ${ }^{12}$ And of a chief, Te Rangimairehau, who pleaded not to be killed, but was 'hurled onto a fire where he was roasted alive'. ${ }^{13}$ And of Te Aokaitu, tied up, taken to an oven and made to sing in the last moments of his life. Carkeek provides an English translation of his death song. 'One by one, those of that tribe [Ngati Apa] who had been captured were duly consigned to the ovens, ${ }^{14}$ Carkeek says, making it clear that no other end was imaginable.

Our guide was more reticent. In fact she spoke in such a careful way about what happened after the battle that later I was unsure whether she said that the defeated men were eaten or not and if they were, why that happened and whether she had any opinion about this. I took from her reticence, or perhaps it was diffidence, that this battle between people whose descendants still live nearby and the eating of one's beaten enemies are still subjects to be wary of.

\footnotetext{
${ }^{12}$ Carkeek 35.

${ }^{13}$ Op. cit. 36.

14 Ibid.
} 


\section{Hair}

The concierge at my hotel in Sydney told me that although he worked just down the road, he would never visit the Jewish Museum because it was, in his words, too confronting. Inside, he said, there is a lampshade made of human skin.

Inside the museum, there is no such thing, but there is a blanket made partly of human hair. Apparently there are certain words which have the power to evoke the collective memory of the Holocaust ${ }^{15}$ and 'hair' is one of these words.

There are two striped coats like the ones you see in the movies, and some handmade wooden tools from the camps - a comb, a spoon and a knife. I had never seen these striped clothes up close before. The coats were small. Inside their glass case I could see the coarse weave of the fabric. There are photographs and maps and small cards explaining the objects. A comb was valued, it says, because keeping yourself clean helped you to avoid lice and that might make the difference between living and dying.

There are people too. Some of them lived through the Holocaust. Some are the children of people who lived through the Holocaust. There is also a kosher café, which makes excellent vegetable soup, and a shop selling books and keyrings.

In my hotel room in Darlinghurst Road that night, I hear the voice of a museum containing objects that have survived the Holocaust of the Jews. Inside the museum there is so much pain, and also so much love and banding together. There is anger too. All this is held in place by steel walls. This is not a metaphor.

I want to open myself up to the voice of this museum and, at the same time, I am frightened of this place with its blanket and its striped coats. I wonder what will happen to me when I go back there in the morning and meet some of the people who work there and the survivor volunteers. To prepare myself, I practise sending parts of myself across the road, through the heavy doors and into the museum. I let them walk around a bit in the dark, and then I call them to see if they will come back. The first time I do this, all the parts come back so quickly that I wonder if they even went to the museum. I think perhaps they hid somewhere down the road in a café, waiting for me to call. The second time I send them, they come back but more slowly. I know they went inside the museum this time because of a voice which they bring back with them. It begins as I write the words 'objects' 'pain' and 'anger'. Dein aschenes Haar Sulamith, it says.

\footnotetext{
${ }^{15}$ I use 'Holocaust' with a capital ' $\mathrm{H}$ ' to show respect, although it worries me that this also implies singularity.
} 
In the months since that night in Sydney I have begun to find those sentences about the voice of the museum rather ridiculous. I was away from home, I tell myself. I was by myself and thinking a lot about the Holocaust and therefore it would be quite natural to imagine a noise coming from the front of the building as if from a mouth and rolling across the road towards me in circles of dark grey heated air.

But last night, near the end of Austerlitz, by W. G. Sebald, I heard that voice again. In the midst of page 247, which I will admit I was reading rather dreamily, I found a description of Jacques Austerlitz searching for an image of his mother in some scraps from Der Fuhrer schenkt den Juden eine Stadt a Nazi propaganda film about Theresienstadt. By chance I turned on the television on 20 February 2012 and saw some of this film.

The version I saw has no soundtrack but it has late afternoon sunlight, just as Sebald says, and people tending vegetable gardens. One woman holds up a carrot, smiling and laughing as if she is proud of what she has grown. There are families where parents talk together and their children play nearby. No one is thin. I saw only one indoor scene - a barracks with bunks. In that scene a nurse, wearing a yellow star, spoke to a woman seated on a bunk. I think she might have been reading. The woman sat awkwardly because the bunk above did not allow her to hold her head up straight. A family sat at a nearby table. None of the people in the barracks looked sick. I did notice that the barracks was a place where many, many people slept. I found myself searching each scene for Austerlitz's mother, even though she is a fictional woman lost by a fictional man, and trying to remember and notice everything that I had seen in the two or three minutes of film.

Austerlitz plays and re-plays the film. No matter how many times he watches the faces, looking for the mother he last saw when he was four, he does not see her. Desolate and desperate, Austerlitz finds a way to slow the film down to a quarter of its usual speed.

Everything is changed. People move as if asleep. Their eyes close and open in movements you might not usually see and when they walk they seem to hover slightly above the ground. The edges of their bodies blur and dissolve. Damaged sections of the film make strange patterns like drops of water under a microscope. A polka becomes a funeral march. A male voice, which had spoken before in 'high pitched strenuous tones' of task forces and people 'willing to work' being 'deployed' in various different ways, became a menacing growl. The words 'menacing growl' made me sit upright. My heart beat faster than normal, as it does just after an earthquake.

At an earlier time, when I had considered making an attempt to describe the voice I heard that night in Sydney, I had been thinking of the word 'roar' but I had given up because 'roar' sounded like the sound I used to make for my son when I read him stories of lions who lived in meadows. I couldn't describe the depth of the bass in this sound and I couldn't describe a frequency that I heard with my old brain, not my cerebral cortex. 
Sebald's attention to this noise reminds me that I have heard a menacing growl once before. Once, in a small town not far from where I live now, I knew a girl who had been kept as a kind of hostage for several weeks. One night, after reading and re-reading her statements to police, I dreamed of a huge flaming wooden wheel as high as a house, like a reel for electrical cables, rolling over paddocks and fences. This image was accompanied by a noise I have never tried to describe. I learned from this noise that the man had meant to kill the girl. This knowledge was something I never spoke of, knowledge of this sort slightly shameful to a person brought up in an atmosphere of light stained wood, plastic dinner sets and science.

Marianne Hirsch and Leo Spitzer, two eminent scholars, researched the life of her parents in Czernowitz ${ }^{16}$ and the on-going life of Czernowitz in her parents, their friends and in the next generation. ${ }^{17}$ On one of their trips they travel to Czernowitz with Marianne Hirsch's parents, who have not seen this city since they left it after the war. For Marianne Hirsch, one of the most potent objects in the story of her parents' survival is a tiny photograph (1x1.25 inches) of her parents, taken by a street photographer in Czernowitz. On the back of the photograph, her father has written ' $C z$ 1942'.

Hirsch and Spitzer interrogate the photograph. Her parents' outfits, their facial expressions, their body language, their level of nutrition, the buildings in the background all attract their attention. They compare the photograph with others from the Warsaw or Lodz ghettos. They consider young love as a resource. They consider her parents' commentary on the photograph - 'Here we are during the war'- and their description of their 'relatively lucky circumstances'.

After this they interrogate history. The date the Czernowitz Ghetto opened. The date of its closing. The numbers of Jews deported in 1941. The waiver that saved her parents from that deportation. The deportations in 1942. The rules for the wearing of the yellow star. How big it had to be. How it was attached. All these attract their attention.

But they want the photograph to 'reveal itself even more', ${ }^{18}$ so they make a digital scan of the 1 by 1.25 inch photograph and blow it up to about 4 inches by 5.5. Now they find a blurry spot on the lapel of Carl Hirsch's jacket. Is it a yellow star? But weren't stars bigger than that? Could her parents have been walking openly in the city in 1942 if they were marked as Jews? If it was a yellow star, why did her mother not have one on her coat? Was the spot a mark left by stitches after taking off the yellow star?

\footnotetext{
${ }^{16}$ This spelling dates from the time before the end of World War I, when the city was part of the AustroHungarian Empire. Long after the city became part of Romania, German-speaking Jews continued to use this German name for the city. I use their spelling when speaking of their attachment to this place.

${ }^{17}$ Hirsch, Marianne, and Leo Spitzer. Ghosts of Home: The Afterlife of Czernowitz in Jewish Memory. Berkeley: University of California Press, 2010. Print.

${ }^{18}$ Hirsch and Spitzer 164.
} 
But stars were fastened with a safety pin. If they were hiding their Jewishness, how did they feel about having their photograph taken in the main street? Did they buy the photograph only in order to take away the evidence of their presence on the main street that day?

When they refer the questions back to her parents, some doubt emerges about the date on the back of the photograph. Their final investigation of the spot on Carl Hirsch's jacket is reflexive. Here the authors describe their own 'desire, if not need, to penetrate more deeply into a world that had been opened up to us ever so slightly. ${ }^{19}$

${ }^{19}$ Op. cit. 166. 


\section{Stephen Schpielberg}

In America, Europe and Australia, museums to commemorate the Holocaust began to spring up in the mid-1980s, as never before. I have heard several theories about why this happened at this particular time. One woman, whose family contains several Holocaust survivors, told me that she thought Stephen Spielberg's filming of oral histories of survivors was a powerful factor in opening up the subject of the Holocaust. Spielberg, a wealthy and powerful American Jew who carried with him the authority of Hollywood success, gave these people a voice, she said, after the Holocaust had taken it away. After that, she said, they felt they had, for the first time, a mandate to speak about these events.

Some particular events such as the trials of high-ranked Nazis in Germany in the 1960s and the trial of Eichmann in Jerusalem in 1961 are said to have brought the Holocaust into the minds of more people. When I think back to that time, I am dimly aware of famous Nazis being hunted in South America but much more aware of the arrival of television and westerns and the Beatles travelling to India and the first man landing on the moon.

In 1967, the year of the Six Day War, I wore out my first copy of Exodus. I cannot remember how this book, published in a distinctive bright-blue-covered paperback in 1959, came to me in Masterton in 1967. Perhaps everyone was talking about Israel that year, even in small town New Zealand? My hero was Ari Ben Canaan, the soldier/farmer in his shorts and blue shirt. I liked that his father carried his own brother over the mountains from Russia and built the kibbutz with its sprinklers and orange trees and argumentative violin-playing socialists. I liked that Ari was a reluctant soldier, wounded in spirit from all the fighting and dying. But I also liked it that he won. In any case, my parents were as used to this wearing out and replacement of books as they were to my other particular needs and quickly bought me a replacement copy.

I wish that by 1970 I had known as well of the poems and death of Paul Celan who 'went into' the Seine that year from the Pont Mirabeau. But I had nothing to bring to those poems then and not for many more years.

Others have said that the survivors were busy after the war, re-building their bodies, trying to find relatives, finding a place they could settle, making families and livelihoods. Only later, when this work had been done, could they pay attention to documenting what had happened. I think of them at this time as working their way up Maslow's Hierarchy of Needs ${ }^{20}$ for the second time in their lives.

\footnotetext{
${ }^{20}$ Maslow's Hierarchy is discussed in more detail on page 192
} 
When asked, why talk of this now, they sometimes said they knew that their own time was running out and they wanted to leave a lasting message to their children. Some had said very little to their children about what happened to them. Some had said a lot. Their children, at this time, were perhaps busy, enjoying the life that America or Australia had given them; not always keen on looking back through the black hole, to Europe. But they were maturing as their parents were ageing and their parents wanted to show them what they had seen and what had happened to them, while they could.

The survivors also wanted to show non-Jews what they had seen and what had happened to them. They believed that if they said what had happened, and showed what had happened over there, people would understand Jews better and that would help to prevent antiSemitism and racial prejudice of all kinds from taking power again.

I was here, in New Zealand, beginning to read about the Holocaust in the same period of time as the museums were opening and movies like Schindler's List were being made.

And now here I am, still in New Zealand, wondering if my writing is a sort of automatic writing generated by big swirls of events that happened in the 1960s in countries I have not visited.

More than a year ago a friend, who speaks five languages and reads several more, told me it would not be possible to write about the Holocaust from New Zealand. There's so little to say here, she said. You should go to Europe.

But this is where I am, I said. That is the problem. This is where I am from, this is who I am, and this is where I am.

This work has already provoked different reactions from anything I have written before. The reactions began long before anything was written. Generally, when people asked me questions about my research and I answered, they would fall silent. In Pākehā New Zealand communication silence means 'Stop talking about this,' or 'Stop doing this'. By continuing with this work despite these cultural warnings I have probably taken on some of the unattractive characteristics Reuel Anson Lochore described amongst the Jewish refugees who came to New Zealand before the war.

They lack discretion and tact ... On social occasions, and other occasions too, they talk loudly and untiringly about their own affairs. Being bad listeners they cannot take a hint, nor sense an attitude from what we prefer to leave unsaid. ${ }^{21}$

\footnotetext{
${ }^{21}$ Lochore, Reuel A. From Europe to New Zealand: An Account of our Continental European Settlers. Wellington: A. H. \& A. W. Reed, 1951. Print. 87.
} 
At other times people have brought up the well-known problems of writing about the Holocaust, as if I might not have heard of them or as if I should retreat in the face of them. The language people used for the risks I was taking showed that I was not merely risking artistic failure but also their personal contempt.

Thomas Keneally wrote Schindler's Ark after the story was touted to him by Poldeck, the self-appointed archivist of the Schindler Jews. According to Keneally, Poldek, who sold briefcases and handbags in Los Angeles, said:

I know a wonderful story. It is not a story for Jews but for everyone. A story of humanity man to man. I tell all the writers I get through here. Sitcom guys. Reporters for the L.A. Times . . y you see everyone needs a handbag, everyone needs an attaché case. So I tell everyone I know the greatest story of humanity man to man. Some listen - an article there, a news item there ... But it's a story for you Thomas. It's a story for you, I swear ... ${ }^{22}$

Keneally had many doubts about telling the story of Schindler and 'his' Jews, so many that he found it necessary to carefully spell out his rationale for persevering with the book. One anxiety was that telling any Holocaust story that 'made it possible for readers to imagine the Holocaust, could be seen by some as an encouragement to Israeli hardliners'. ${ }^{23}$ He finds a comparison in the question of whether stories about the Irish potato famine would inflame IRA violence against Britain. Then he mentions stories about the colonial settlement of Australia and their possible effect on Aboriginal people.

I am intrigued by these comparisons. I notice Keneally's extrapolation from the Schindler story to other situations which are important to him. I take from this that readers decide for themselves what a story means.

Sometimes, when I described my intentions for this project, people spoke about the actions of the State of Israel in relation to the Palestinian people, which I took to be an argument that in the present situation, the Holocaust can, or perhaps should, not be talked about because of the continued suffering of the Palestinian people. Committed in my particular New Zealand way to the idea that we should act as though human beings are mostly reasonable, I do not, at present, believe that either one of these topics must make the other invisible.

\footnotetext{
${ }^{22}$ Keneally, Thomas. Searching for Schindler: A Memoir. Sydney: Random House Australia, 2007. Print. 9.

${ }^{23}$ Op. cit. 125.
} 
Later, after Cairn was mostly written, I came across a discussion between Khalil and Farouq, two fictional characters in Teju Cole's Open City, who complain that the Holocaust suffocates and deafens them when they try to discuss Israel's treatment of Palestinians.

It's true, Khalil said. Europe is not free. The rhetoric claims freedom, but only the rhetoric. If you say anything about Israel, you have your mouth plugged with the six million. You're not denying it, I said quickly, you're not actually questioning the figure are you? That's not the point, Khalil said, the point is that it is against the law to deny it, and that it is also against an unwritten law to even bring it up in discussion. Farouq assented. If we try to speak to the Palestinian situation, we hear the six million. The six million: it was a terrible tragedy, of course, six million, two million, one human being, it's never good. But what does this have to do with the Palestinians? ${ }^{24}$

The six million suffocate and silence Khalil and Farouq with their sheer numbers. I follow them this far. I have no trouble believing the particular way the Holocaust acts for them after experiencing the way it acts in reverse. But I am left unsure whether they would like to 'deny it' if they could, and if they would like to argue for a smaller number if it were legal to do so. Khalil and Farouq's discussion moves then to a rejection of the Holocaust as 'unique suffering'.

As it took shape and had a name, Cairn irritated some readers because it did not provide the gas chambers and piles of bodies which they expected to be at the core of any writing about the Holocaust and I, the author, seemed insufficiently undone.

I also know that this work repels some people and makes others feel guilty. One man, a close relative, told me that he knows he 'should' read it, but he doesn't want to because he doesn't want to have the Holocaust in his mind. He has done whatever was necessary to avoid this pile of paper 'about the Holocaust' which has entered his house.

Another unrelated man said my work made him feel guilty about how little he is doing to help people who are being oppressed now. Others said that as they were reading, they wondered what they would have done to help if they had been alive in those times. I notice that none of these readers has imagined him or herself as a Jew.

\footnotetext{
${ }^{24}$ Cole, Teju. Open City. London: Faber and Faber Ltd., 2011. Print. 122.
} 
Yesterday I read an essay in which Tony Judt describes the way each nation of post-war Europe has needed to forget the Jewish Holocaust at some times, and needed to remember it at others. ${ }^{25}$ Language was always a willing scab in the cause of forgetting. These were not Jews, they were 'déportés' described on memorials as having 'died for France'. They were 'workers', they were 'victims of Fascism'; they were anything but Jews.

In Judt's opinion, certain trials in the 1960s, like that of Eichmann and of the Auschwitz guards, played a key role in bringing the actions of individuals to popular attention.

Sometimes, he says, it was a new event, like the Six Day War in 1967 or the killing of Israeli athletes at the 1972 Munich Olympics, or even a television event, like the mini-series Holocaust which showed in West Germany in 1979, which brought the Holocaust of Jews to the notice of non-Jewish people.

${ }^{25}$ Judt, Tony. Preface. Postwar: A History of Europe Since 1945. London: Vintage, 2010. Print. 803-831. 


\section{Maps and guides}

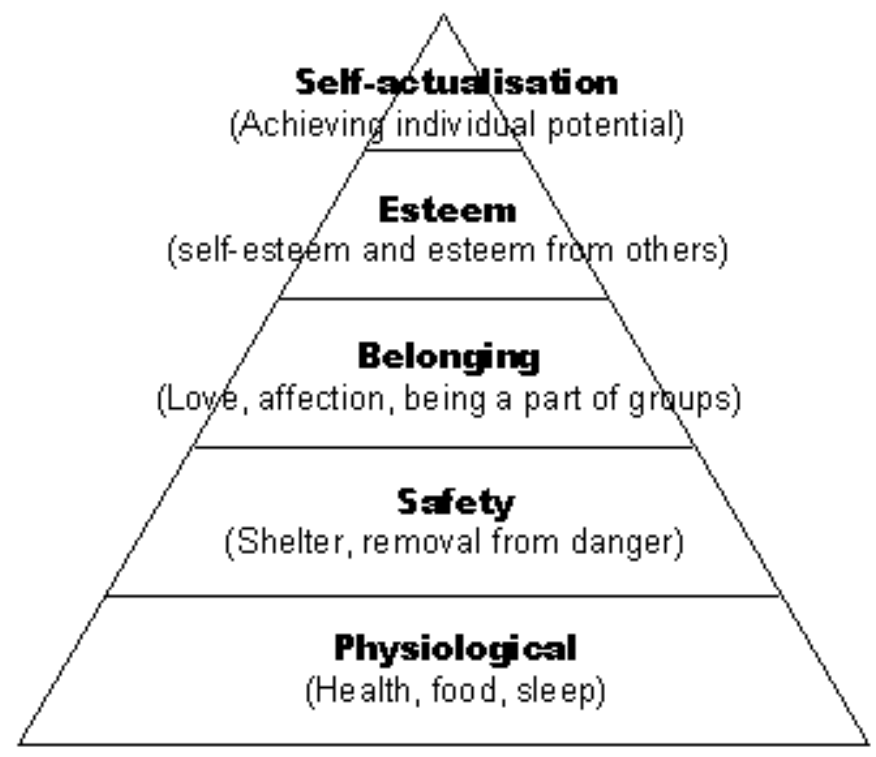

Recently I found this particular diagrammatic version of Abraham Maslow's "Hierarchy of Needs". ${ }^{26}$ Abraham Maslow, the son of Russian Jewish immigrants, created the hierarchy in America during the 1940s to explain the conditions people need to be as happy and creative as they can possibly become.

Maslow's theory is that deficits in the needs on the bottom of the pyramid motivate human beings to try and satisfy those needs before meeting those on the top. The hierarchy also works from the assumption that the needs lower down are more important than the needs higher up. Twice in the last year I have heard that listening to poetry was important to some people in the ghettos but, past a certain point of hunger, nothing was as important as food. Behind the theory and the diagram there is a sense of instinctual striving from the bottom and the possibility of upward movement.

The hierarchy itself has been described in all sorts of ways and used for all sorts of purposes but it is always about people striving to make their lives better.

It is almost a convention for museums about the Holocaust to have dark grey walls. Often the Holocaust exhibit pathway follows the process of genocide in chronological order - it begins with identification, then exclusion and violence, proceeds to confinement in ghettos and concludes with the journey to a camp.

26 “Maslow's Hierarchy of Needs." changingminds.org. n.p., n.d. Web. 20 Oct. 2012. 
At the end of that journey there is immediate death by suffocation or selection for work, which meant slow death. Suffocation is so much the symbol of the Holocaust that sixty years later, members of a Nationalist group in Ukraine make a hissing noise when they want to threaten people by evoking this event. ${ }^{27}$

I notice that the process of genocide attacked the Jews from the top of the hierarchy burned their art and books, locked them out of universities, and then took away their positions and their titles. Think of all the stories of doctors who couldn't practise and teachers who couldn't teach. Then it stopped them belonging to groups and alienated people from each other - neighbours who used to be friendly stopped speaking and people were driven to sending their children away or leaving old people behind as they fled. Then it proceeded to take down the formal and informal structures of law and safety. And finally, it took away their food and their rest and, last of all, their air.

There was no way for these people to come back. After the war, their neighbours said as much.
we will not let you in
this is our house now
you were sent to a concentration camp, you were not expected to come back. $^{28}$

Sometimes a museum represents this by making the physical space close in as the process nears its end. Sometimes the museum keeps shoes or spectacles or leaves as a symbol of all who died. The museums I visit all show that a tiny group of people survived, spread across the world, even coming this far, and that they wanted most of all to build families.

The more I read, the more I think that we move forward too easily and not enough time and space and attention are spent on the deaths. Somewhere there should be rooms and rooms of total darkness, maybe an unbroken line of buildings three miles long, like the Koloss von Prora, Hitler's workers' resort on the Baltic, entirely made up of rooms of total darkness with one small room of survivors' stories at the end. Corridors could lead away from this small room to many other rooms, one bathed in fierce red sunshine for Australia and a tiny green and blue one for New Zealand. But this would not be a museum. It would be a threedimensional story.

\footnotetext{
27 “Hooligans beef up for English football invasion." The Dominion Post 14 May 2012: B3. Print.

${ }^{28}$ Liba, Moshé. The Holocaust - Between Me and Myself. Wellington: New Zealand Jewish Chronicle Publications, 2000. Print. 24.
} 
Increasingly, parallel with my reluctance to 'move on', I find myself wanting to know more of what was there before the rooms became empty and dark and how the survivors and their families lived, afterwards. Deborah Knowles, the daughter of a Holocaust survivor, is much clearer about why she feels this same desire:

It is important for us to try to understand what Jewish life had been like before Hitler, so that it becomes possible to build a bridge over the void that divides the time before the war from after the war... Maybe then we can establish a sense of community and see ourselves as part of a group of people who lived before the Holocaust, who kept themselves alive during it and came out the other side. ${ }^{29}$

As a child, Daniel Mendelsohn used to write to his grandfather Abe in Miami and ask questions about the names and dates of birth of his relations. Abe would help if he could, but sometimes he did not know the answers to Daniel's questions. On his visits to the family in New York, Abe told Daniel his stories, all of which proceeded in 'vast circling loops', ${ }^{30}$ each story containing another, each event needing to be explained by another story and another, a method which Abe was happy to explain to Daniel; stories to be found buried inside each other like Russian dolls, he said, not sitting beside each other like dominoes. Abe's stories are about everything, Daniel realises, except Abe's older brother Sam, Sam's wife and his four daughters, all killed by the Nazis, as family members used to say, whenever the subject came up.

These six people were, from Daniel's point of view, 'not so much dead as lost, vanished from the world', ${ }^{31}$ as well as from his grandfather's stories. This absence sends Daniel off on a decades-long search for information about what happened to these six people.

At the end of his search, looking back on these childhood times, Daniel Mendelsohn finds that already, in his childhood, he had lots of important pieces of information about these six people, but somehow did not fully understand what he had. This is what he knew:

Sam and his wife and four beautiful daughters, one of whom was called Bronia, were killed by the Nazis,

Sam had some trucks and the Nazis wanted trucks,

Sam was one of the first on the list,

They were hiding in a kessle,

\footnotetext{
${ }^{29}$ Knowles, Deborah. Introduction. Mixed Blessings: New Zealand Children of Holocaust Survivors Remember. Ed. Deborah Knowles. Auckland: Tandem Press, 2003. Print. 9.

${ }^{30}$ Mendelsohn, David. The Lost: A Search for Six of the Six Million. New York: Harper Collins Publishers, 2006. Print. 32.

${ }^{31}$ Op. cit. 15.
} 
A neighbour turned them in,

Their shiksa maid turned them in,

They raped them and killed them all.

For a while, when he is young, Daniel thinks the place they hid is a 'castle', the word said by his grandfather in his particular accent. Daniel wonders if a kindly Polish aristocrat took in a Jewish butcher and his children. But no, after circumnavigating the world and finally returning to a place he had been before, Daniel finds the kessle. It is a hole, dug eight or nine feet deep and three feet wide into the earth, under the floor of the living room in a house in Bolechow in Ukraine; the house now occupied by alcoholics or drug addicts from southern Russia. Daniel forces himself to climb down into the hole and finds himself thinking of a coffin. Kestl, it turns out, means 'box' in Yiddish.

I find, as I write this list of what Daniel knew, that I had not, on the first, or second, or even third time of reading his book, really noticed the matter of Sam's trucks. More and more, in the last year, I have been noticing the role that the drive to accumulate wealth played in the treatment of Jews in the Holocaust.

In laying out the path of my own investigations, I have decided to follow the example set by Abraham Jaeger, grandfather of Daniel Mendelsohn, author of The Lost: A Search for Six of the Six Million. Abraham's stories always started so wide that young Daniel never quite knew what the story would be about. In the second stage the story wandered around, taking digressions and entering many cul-de-sacs - so many that Daniel always wondered if any story would emerge. In the third stage a particular story would show itself and having done that, it would walk inexorably towards its own disastrous or strange or inspirational end.

All the time he was telling stories to his grandson, Abraham's own story was still happening. Abraham Jaeger's story involved many languages, towns with several names, several wives and a brother lost or perhaps abandoned and presumed to have died in the Holocaust along with his wife and four girls. Abraham gave Daniel the beginning, the early middle and some of the ending of this story of his brother's family but left him holding a big white space between the middle and the end.

Daniel's quest to fill that big white space fills the book. The quest takes him everywhere and lasts many years. He labours endlessly, questioning old men and women and piecing together what might be true and what might not be true. He finds several guides. Luck plays a part too, but in the end, it turns out that some of the most important information was right under his nose. 


\section{Time is by far the most artificial of human inventions}

Billy Pilgrim, the hero of Kurt Vonnegut's Slaughterhouse Five, comes unstuck in time. Billy can come unstuck at any moment. This is not the result of interference by aliens. It just happens.

The first time it happens Billy is a chaplain's assistant lost behind German lines during the Battle of the Bulge in 1944. While dying of the cold, he travels to the time before his birth and to the time of his own death. He would have liked to stay longer at his death time, bathed in violet light and vibrating, but instead he takes a long train trip in a boxcar, spends a little time in a prison camp, shelters in a deep cool slaughterhouse in Dresden while the city burns and then works in the hot ruins, accompanied by a few men and a horse. One of the men is a Māori prisoner of war.

As I write this I find myself inhabited by the tragic, laconic and simultaneously amused tone of Kurt Vonnegut. This tone is something Vonnegut brought home with him after his own experiences in the Battle of the Bulge and in Dresden during the burning. I'd love to know if, in addition to terrible memories, he brought back a diamond the size of a pea, like the one Billy Pilgrim found sewn into the hem of a coat the Germans gave him in a prisoner of war camp.

Karel Beran, another man in a boxcar, looked out at the city of Dresden twice from the top of a railway bridge. The first time the city was intact. The second time, just a few weeks later, another train stopped on the same bridge and again he looked out. This time nothing was standing except chimneys.

Sometimes Billy Pilgrim is an optician. Billy the optician lives in llium, New York, with a chubby wife and a small business empire. In that part of his life it is 1960.

In yet another part of his life Billy has been taken to the planet Tralfamadore, where he lives with Montana Wildhack, a mate the Tralfamadorians have provided, in a special zoo. Their house is a geodesic dome made to simulate a house on earth.

Outside the dome there is a guide who tries to explain some of the ways humans act and think. One of the hardest things to explain is our earthling view of time. From the Tralfamadorian point of view every moment in time exists simultaneously, all the bad ones and all the nice ones, all the past and all the future, sitting right next to door to each other like the high points in a mountain range. Knowing the past the future and the present, all at once, changes everything. 
In spite of all their knowing, or perhaps because of it, Tralfamadorians do not enjoy thinking about bad moments. The night that they bring Montana Wildhack to Tralfamadore is a bad moment for her, and she screams a lot. The Tralfamadorians consider this to be a terrible breach of manners, so they lower a curtain over the dome, as we might do with budgies in a cage if they were making too much noise.

There probably is no planet called Tralfamadore and no skinny man shaped like a Coca-Cola bottle, with the name Billy Pilgrim. I know that. The trouble is that ever since I first read this book, in 1975, I have sometimes been able to see time in the Tralfamadorian way. Not only that but I find myself wondering how other people can ignore the Tralfamadorian aspects of places and situations.

So far this sounds perfectly rational; however, if I were to be honest, my identification with the Tralfamadorians goes much further than this. I feel that I must be part Tralfamadorian, if not genetically, then by the strength of my emotional connection. It's odd that I could identify myself as Tralfamadorian, when they themselves would disdain this form of pseudoconnection.

Just today, for example, I read that the Kāpiti coast, where I live, and Kāpiti Island, which is fifteen minutes away by boat, used to be part of one stretch of land which connected the South Island to the North Island. At that time the sea was about 300 feet lower than it is now. I can see this in my mind. The sea draining away like water in a bath. Glaciers growing hundreds of miles away.

The Tararua Ranges, which I see in the morning, covered with snow in the winter, were once a long ridge under the sea. Pressure from one side of a fault line, meeting resistance from the other side, lifted the land and folded it into the shape of mountains. I can picture this too, rock and sand, folding as plasticine or pastry folds. Kāpiti Island, they say, was raised at the same time as this mountain-making. Land on the Kāpiti coast is still growing in some places; building upwards and outwards by about one metre per year. Just this small yearly change, repeated and repeated and repeated, could make a land-bridge to Kāpiti Island one day. In other places, just a few kilometres away, land disappears every time there is a storm.

I don't know whether this land-bridge is what happens or something else entirely. Maybe there is another day of folding and a wave the size of a mountain range drowns the children's playground and the skate-park and the miniature railway and the Raumati Social Club and all the houses on the line of the proposed four lane expressway and my house and all the people on the Kāpiti coast. No one here on earth would blame me for not knowing this or for being shocked if I were to find out that this happens soon. 
Jacques Austerlitz, a fictional man in W. G. Sebald's book Austerlitz, who lost his family, his language and even his name, experiences time in a way which is equally as strange as Billy Pilgrim's.

Instead of floating about in time, as Billy does, Austerlitz feels compelled to resist time in the hope ... that time will not pass away, has not passed away, that I can turn back and go behind it, and there I shall find that all moments of time have co-existed simultaneously, in which case none of what history tells us would be true, past events have not yet occurred but are waiting to do so at the moment when we think of them, although that, of course opens up the bleak prospect of everlasting misery and neverending anguish. ${ }^{32}$

Time, says Jacques Austerlitz, is 'by far' the most artificial of human inventions.

The dead are outside time, the dying and all the sick at home or in hospitals and they are not the only ones, for a certain degree of personal misfortune is enough to cut us off from the past and the future. ${ }^{33}$

Austerlitz finds that certain places have 'more of the past about them than the present' ${ }^{34}$ In those places, he feels 'the current of time slowing down' and that future and past events are all present. A person might feel, he says, that he has an appointment to keep in the past and that he must go in search of places and people who have some connection to him 'on the far side of time'.

In Paris, in 1960, Austerlitz boards with a Jewish woman near the Pont Mirabeau, but at that time he does not concern himself with her story, which was then the recent past. Instead he studies architectural history.

In Paris at one unnamed time near the present, Austerlitz searches for his father in the streets near his last known address, always thinking that his father might emerge from some entrance and walk towards him. He also sits in cafés and tries to imagine his father writing letters in those cafés, or his father caught in the raids of August 1941 or July 1942, travelling through the Greater German Reich in his plum-coloured suit and velour hat.

I sit upright and register the reference to the Pont Mirabeau, the bridge from which Paul Celan entered the Seine in 1970.

\footnotetext{
${ }^{32}$ Sebald, W. G. Austerlitz. Trans. Anthea Bell. New York: Modern Library, 2001. Print. 100-101.

${ }^{33}$ Ibid.

${ }^{34}$ Op. cit. 257.
} 


\section{Awkwardness}

Last week I found that I was talking with a woman of my own age, from my own country, but whom I don't know very well, about the Holocaust. She started the conversation by asking about a trip that I was about to make. Her question added a small risk of social difficulty to our conversation, as questions do. I could have answered this question in a general or evasive way but I chose in that moment to describe my intention to visit museums in Australia and New Zealand which have Holocaust exhibits. I added a thousand times as much risk of social difficulty by choosing to say that, and it is a measure of something that this woman chose to join me in the conversation.

A conversation like this is always a bit uncomfortable. I have carried out some informal research into this and I have found that conversations about the Holocaust have just about double the usual ratio of silences to speech. Sometimes silences occur in these conversations which no one knows how to end. One of these silences grew between me and a German friend in 2002 and it has not been broken yet.

Last week's conversation went quickly to a bus tour this woman had been on which included Auschwitz as part of the package. She told me about her visit to the Jewish Museum in Berlin, which reminded her of Te Papa, and where, she felt, the building overwhelmed the objects. She also told me her impressions of the stone fields of the Memorial to the Murdered Jews of Europe. She told me about height as a carrier of meaning in this memorial. In some parts of this field of stone plinths you can see people walking around and in other parts, as the height of the plinths increases, the people disappear. She believes that this capacity to make people disappear is the point of this monument.

After a few minutes of descriptions of heritage sites and monuments, she stopped talking and looked away, downwards and to the right, where two women were chatting in an office in Wellington in the late 1970s, both young and fashionably dressed.

After just a minute, the woman raised her eyes and looked at me again.

'I remember how shocked and surprised I was when I met a woman at work whose parents had both been ... you know ...' she said.

Shocked and surprised, she said. That people had been in concentration camps. That is what she didn't say. Yesterday, as I wrote this, I felt confident that I knew what she meant. She meant, and all this would have rolled off my tongue without hesitation, that she grew up in a country where she felt almost completely safe. By the time news from the rest of the world arrived here its voice was faint and barely audible above the noise of the waves. 
Our sea is made up of certain blues. Sometimes, just before the weather changes, our sea is so pale it fades into the sky. At these times, the sea is almost silent. Sometimes our sea is bluer than a cornflower. These blues are inside us, enshrined beyond anything conscious, alongside the smell of hot sand and the sound of breakers arriving from thousands of miles away. Yesterday, in Amy Wilkinson's diary of Kāpiti Island during the 1930s and 40s, I came upon a paragraph in which, while describing the colours of the sea, she seems to rise from the sand and into the sky, her arms outstretched like a saint. Such is her intense attachment to the sea.

If you asked my colleague, now, if New Zealand really was as safe as we felt when we were young, she would say yes, for her, it was. Her adult self will know that not everyone in that country at that time felt as safe as she did, but I bet that when she thinks of her own childhood, it is a place of lamb chops, vegetable gardens, school milk, school journals and worries no greater than a bad dream on a single night. This picture of our bountiful nutrition is not a figment of my imagination. Just this morning I read that in 1936, Sir James Parr, who had recently retired as New Zealand High Commissioner in London, told a League of Nations meeting in Geneva that according to the latest year's figures, New Zealanders ate, per person, an average of $37.7 \mathrm{lb}$ of butter, and a staggering $236 \mathrm{lb}$ of meat. Coming just a few years after the Depression, this was a matter of pride. Italians at the same time ate 2-3 lb of butter and $35 \mathrm{lb}$ of meat. ${ }^{35}$

Yesterday I thought that the shock and surprise this woman felt when faced, in Wellington, in 1978, with remnants of the Holocaust, was caused by that bounty of milk and meat and the blueness and roar of the Pacific Ocean.

When this woman and I were children in the 1950s and 60s, the War, as people called it, already seemed like something that happened a long time ago. Our parents spoke of it, but they seemed to be living with us, in the present. If, like our family, you had no direct connection to the people who died, perhaps the news of what happened in Europe really would take thirty years to arrive in New Zealand? I wonder if, despite constant reminders from the Jewish community, the news will ever really arrive ${ }^{36}$

A choice my great-grandfather made in 1878 , to come to New Zealand, meant we were not in danger. We do not know the names of his relatives or even where they lived - there is no

\footnotetext{
${ }^{35}$ O'Sullivan, Vincent. Long Journey to the Border: A Life of John Mulgan. Wellington: Bridget Williams Books Ltd., 2011. Print. 169.

${ }^{36}$ A non-Jewish reader told me recently that this question is too highly charged. I think Jewish readers would find it reasonable.
} 
one left now who knows these things. We know he started his new life in New Zealand quickly by marrying a Jewish woman and making a large family. For whatever reasons, Isaac (that was his English name) did not apply for New Zealand citizenship in these years, which meant that in the 1930s, when Jews everywhere worried about their safety, he was not a New Zealand citizen.

I have sometimes imagined him listening to the radio, hearing about Kristallnacht or the Nuremberg laws - things of little interest to most New Zealanders at the time, but much talked about in the Jewish community. Once I went as far as to imagine a whole play in which he receives a letter, in Yiddish, from a sister, telling him how and when his parents died, where they are buried, and asking for him to sponsor her son and his family to come to New Zealand. She doesn't care about herself, his sister says, but he should help the children if he can. In my play he raged and cried and banged his walking stick on the wooden floor and told no one about the letter, not his children who were first cousins of the son back in Poland, and not his wife. Perhaps he was angry because he was ashamed of not having money to help them or because he thought he had left them all far enough behind that no claims could ever be made.

I know, because I have seen the document, that a Member of Parliament provided a character reference for Isaac to use in his application for New Zealand citizenship. The reference describes him as 'indigent' but of good character. I try on the idea that the Member of Parliament was a person for whom my great-grandfather had once made suits. I see Isaac with a tape measure around his neck, kneeling on the floor in his shop in Upper Cuba Street, beside a rather portly ruddy-faced man wearing good quality tweed. I also try on the idea that money changed hands. However it came about, late in life my greatgrandfather became a Jewish New Zealander on paper as well as in his life. His children were already Jewish New Zealanders and their children were Jewish New Zealanders too; well mostly anyway.

In a fictional scene in a book set at Otago University between 1932 and $1935^{37}$ Dan Davin, a New-Zealand-born Catholic writer, has his protagonist Martin Cody challenge a New Zealand-born Jew about his politics. The Jew is a conservative, on the side of the government against the hunger marchers. Hitler is the real enemy of the Jews, Cody says, not the Communists, and if things don't change all the Jews will be dead. Overall it's a morally confusing scene in which Davin allows Cody to know the future and say wise and worldly things to Werner, who comes across as a naïve New Zealand Jew. Cody dislikes Werner, and the reader knows this. But Cody needs Werner onside for political reasons so

\footnotetext{
${ }^{37}$ Davin, Dan. Not Here, Not Now. London: Robert Hale \& Co., New Zealand: Whitcombe \& Tombs Ltd., 1970. Print. 301-302.
} 
he sets out to flatter him and pretends to befriend him. Werner, who has a dreadful need for acceptance, falls for it.

Leaving all this aside, I am most interested in a comment that the New Zealand Jewish character makes. 'Being a Jew doesn't matter in New Zealand', ${ }^{38}$ Ben Werner says. This is a very simple sentence but its meaning is not obvious to me. It might mean that Werner does not see his future life as constrained by anti-Semitism as it would be in Europe. It might also mean that holding on to Judaism itself is not important here. This one comment, written perhaps in the late 1960s, filtered through the eyes of a Catholic New Zealander living in Britain, is all I have of the views of Jewish students at Otago University between 1932 and 1935.

In the Jewish community a lot has been said, and continues to be said, about assimilation as a threat to the existence of the community in New Zealand and elsewhere. I have heard it said that in New Zealand we have a set of factors which are particularly potent in producing assimilation. Remoteness from other Jewish communities. The small size of the community. The high rate of intermarriage. The lack of Jewish education. There may be others factors too, which I am not aware of.

My own first direct contact with Judaism was being taken to the Jewish Community Seder in Dunedin when I was about ten. There were lots of old people there and only one or two other children. The other children were boys and they seemed to know all about what was going on.

There was a meal of sorts, but strange - a bowl of salt water, a hard-boiled egg, a sprig of parsley and some matzos. I knew that word, 'matzos'. Mainly, people were reading and singing from a book which opened at the back. One page was Hebrew writing and on the opposite page the Hebrew was transliterated into English letters. I tried to imagine that I was in a foreign country, listening to the radio. One day, out of all those voices, I would understand something. I tried to match the syllables to the sounds I heard, but the sounds moved on so quickly and even when I found a sound or a pattern of sound I had no idea what it meant. I could only watch; sit when they sat, eat when they ate, try to turn a page when everyone else did and hope that I did nothing wrong. The room was cold. Only one or two people spoke to me.

At around this time I also remember going with my mother to meet a very nice man with an accent who worked in the D.I.C., which was a department store. He wore a tape measure around his neck, like a doctor's stethoscope, and he seemed somehow to be worth more than his job selling shirts and school uniforms.

${ }^{38}$ Op. cit. 301-302. 
In my parents' bookshelf in the 1960s there was a book with a burning wheel on the cover which described Nazi war crimes. I don't ever remember opening it in those years, or being told not to open it. It was just there, in the non-fiction section, next to a guide to the identification of New Zealand native trees and plants.

This year I saw a second-hand copy of this book in the window of Quilter's Bookshop and I bought it. I opened it once. It is from the early 1950s. It gives a lot of information, complete with black and white pictures which I won't describe. It sticks to the facts.

At roughly the same time as my great-grandfather was applying for citizenship, New Zealand elected its first Labour government. This was the time of the killing chains and men who built their own houses and all that milk-and-meat-and-suspicion-of-artifice-and-decorationand-foreigners and Jews-who-were-already-here-not-wanting-to-stand-out. Still today, the small number of Jews in New Zealand, their relative 'invisibility' culturally and politically, and the low level of anti-Semitism in New Zealand, are often spoken about together as if each one causes the others. ${ }^{39}$

This exact logic meant immigration of Jewish refugees from Hitler before the War was seen by the government of the day and by some New Zealand Jews as a threat. The first Labour government had other concerns too about immigrant Jews from Europe, such as a fear of immigrants driving down wages and increasing unemployment so soon after the Depression, and of possible damage to the livelihoods of local doctors and dentists.

Between 1936 and 1938 the New Zealand government declined 1731 applications from refugees for entry to New Zealand and granted $727 .{ }^{40}$ Some of the 727 died, went to other countries, changed address or were imprisoned before being able to make their way to New Zealand. It is not possible to know what happened to the $1731^{41}$ people whose applications were declined.

These are some of the places the refugees settled: Auckland, Hamilton, Glen Afton near Huntly, Palmerston North, Christchurch, North Canterbury, Pahiatua, Dunedin, Waiouru, Nelson and Hanmer.

In Wellington they settled in Upper Hutt, Petone, Northland and Kelburn Parade. I notice the places are urban and rural and in both Islands, although apparently Wellington was the most popular place for Jewish refugees to settle.

\footnotetext{
${ }^{39}$ Beaglehole, Ann, and Hal Levine. Far From the Promised Land: Being Jewish in New Zealand. Wellington: Pacific Press Ltd., 1995. Print. 2.

${ }^{40}$ Ponton, Francis Arthur. "Immigration Restriction in New Zealand: A Study of Policy from 1908-1939." MA thesis. University of New Zealand (Victoria), 1946. Microfilm. 114.

${ }^{41}$ Since writing these sentences I have been told that the official figures are 'very unreliable' and that perhaps 16,000 people applied to the High Commission in London. The difference between these figures is extraordinary.
} 
In addition to any other concerns about opening immigration to Jews, 'resistance to importing to New Zealand problems of the old world, such as anti-Semitism influenced the government' ${ }^{42}$ In 1939 Walter Nash, a Labour politician, wrote to a Labour Party official:

There is a major difficulty of absorbing these people in our cultural life without raising a feeling of antipathy to them. ${ }^{43}$

It would be fair to say that in the 1930s no one wanted Jews to stand out in New Zealand. One of Beaglehole and Levine's refugee informants puts it like this:

They [the established New Zealand Jews] believe that the more you blend in with the landscape, the less they (non-Jews) will notice you. ${ }^{44}$

This is the New Zealand the pre-war and immediate post-war Jewish refugees came to.

According to a survey of anti-Semitism in New Zealand from the end of World War II until the early 1980s, quoted in Beaglehole and Levine, ${ }^{45}$ incidents of a 'malevolent' kind, such as the defacement of graves, occurred in a series of outbursts with quite long periods between series, and tended to follow 'public comment or media programmes which focused on Jews'.

\footnotetext{
${ }^{42}$ Beaglehole, Ann. A Small Price to Pay: The Refugees from Hitler in New Zealand 1936-1946. Wellington: Allen \& Unwin New Zealand Ltd. and Historical Branch, Department of Internal Affairs, New Zealand. 1988. Print. 22. ${ }^{43}$ Nash, Walter. Letter to Mrs J. Hall, Secretary, Hororata Branch of the New Zealand Labour Party 21 March 1939. Qtd. in Beaglehole. A Small Price to Pay 16.

${ }^{44}$ Beaglehole and Levine. Far From the Promised Land 64. These interviews, done in the early 1990s, asked ninety-three Jewish people, mostly former refugees, about their lives in New Zealand. I note the use of the present tense in this person's description of the New Zealand Jews' desire to blend in.

${ }^{45}$ Op. cit. 91.
} 
Francis Ponton, writing in Wellington in 1946, adds a little more to the picture of how Wellington was looking at its Jews:

We all know the criticism which has been levelled at "the Jews" and as I write (May 1946) ${ }^{46}$ there are anti-Jewish slogans chalked up on many walls in Wellington.

Admittedly these appear in hotels and public lavatories and may evidence little more than the activities of a fanatic with a cess-pool mind, but at the same time I feel that there is a definite feeling against the Jews in New Zealand. ${ }^{47}$

I am shocked. This is not a Wellington and a New Zealand I like to think of. The same day I read Mr Ponton's beautifully written and cool-headed thesis, I heard that Jewish graves had been defaced in Grafton. Perhaps these 1930s voices of caution were right?

${ }^{46}$ Ponton's parenthetical note.

${ }^{47}$ Ponton 107. 


\section{The hole}

At the time I was writing about the conversation between this woman and myself and her reaction to hearing that Holocaust survivors lived in Wellington, but before I came upon Walter Nash's letter, I found the sculpture Rudderstone ${ }^{48}$ in the Botanic Gardens in Wellington. The sculpture has two faces. The one facing the path shows the Old World as shiny black mica-flecked-granite. The black granite is also said to represent the night sky. There is a curved hole in the black granite, which a sign encourages viewers to walk through. According to this sign, if I accept that challenge and walk through that hole, I take my body on a physical and metaphorical journey from old to new.

This is exactly it, I thought. The Old World is where the Holocaust happened. In Poland most of all. The sky over there is black. Heavy and thick with ash. The people over there hated Jews so much that they killed nearly all of them and probably nothing much has changed. That place over there is the Old World. ('Over there' is a term preferred by Israelis, I am told, but making good sense from here too.)

I took some photographs of the black side of the sculpture. I also looked through the hole to see what would be waiting for me if I went through to the New World. It was like looking through a keyhole. I saw a short path leading towards a stand of bush. I took a photograph of this too.

Then I walked through the hole and found myself on the other side, looking at white and blue marble. According to the sign, white is the sky and blue is the sea; the blue in the mind's eye of everyone who lives on the Pacific. I let my eyes linger on that blue. I belong to that blue and it belongs to me.

I let my eyes sweep across all the swirls and shades of the blue. There are some small, irregularly shaped pieces of black in there. I am fine with the fact that there are small clumps of black in the swirls of blue. They are pieces of the Old World that came with us. And, human nature being what it is, there might have been blackness here already. But mostly we have blue here. That is the point.

I look through the hole from the blue side, back towards the black side. I am astonished to see that a short path leads to a stand of bush. The bush there is the same perfect green as the bush on the blue side. The trees are as tall, perhaps taller. In the light of this finding I look further at the irregularly shaped clumps of black in the blue swirls. There are more of them than I first thought, and some of them have a brown area around the black which seems as though it is on its way to turning black.

${ }^{48}$ O’Connor, Denis. Rudderstone. 1997. Botanic Garden, Wellington. 


\section{Warning}

This year I visited four museum exhibits related to the Holocaust. Two were in Australia, two in New Zealand.

On my return from Australia, my sceptical polyglot friend asks me gently whether my visit was satisfying. I think for a while. I say yes. She asks me what exactly I saw there. I tell her that I met six people who had survived the Holocaust, and that I had not met any survivors before. She looks at me for a moment without speaking.

I tell her that they all said, in one way or another, that I could ask them questions. One man said 'you can ask me any questions'. I tell her that although it goes against my upbringing to ask my own burning questions of frail-looking, elderly men and women, I did.

Why do you do this? I ask, and the man says 'To warn everyone'. That part of his answer has a different quality from the rest of what he says. It is very direct. His voice is in a low register.

Yesterday I heard the word 'warning' again, in a speech at the United Nations Holocaust Remembrance Day ceremony here in Wellington. I think the speaker, a politician who was representing the City of Wellington, meant that the day and the ceremony were a warning because they made us remember the catastrophe. I assume the logic is that in the moment that we remember what happened, we are forced by that action to remember that these things can happen and therefore that they might start any day or have started already.

In a welcome moment of plain beauty, my notes of this Remembrance Day ceremony have the word 'warning' by itself on a line and underneath it, on the next line, the word 'bellbirds'.

'What do you think Australia should do about the boatloads of illegal immigrants arriving every week?' I ask the man in the museum. He says it is a difficult matter. He has great sympathy for them, coming with their families and risking their lives. His eyes water as he says this. But the state has to do what it needs to, he says. If the government did nothing, millions of immigrants would come from Asia. The government should do what is necessary he says, but they shouldn't be cruel. That is the important thing. 


\section{For an hour or two I am a witness for the witness}

I met a total of six elderly men and women who go to museums and meet people like me, hoping that with their own bodies and voices, they will give the story of the Holocaust of European Jews the power of the real.

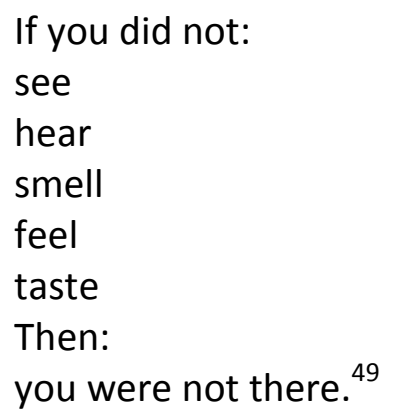

They wonder if we really believe them that they lost almost everyone they knew. They find themselves still forced to speak, seventy-odd years later, for everyone - their young wives and serious boyfriends, the baby sister their parents doted on, their cheeky brothers, all the children in the school photograph and all the children never born. It is an act of persuasion which has, as all such acts do, an uncertain outcome. They do not expect miracles. They do not even expect courtesy.

They hope, by exhibiting themselves outside of any glass case, protected only by their skin and clothes, to reach us in a way that no other sort of museum object could. They reach out towards us by allowing us to reach out towards them. It is an extraordinary act.

None of them says Jews should keep a suitcase packed. None of them speaks about the failure of the Enlightenment or loss of faith in German Kultur. They speak of what happened to them and sometimes this happens to contain one of the common experiences which have become the icons of these stories. It is this way round.

As individuals, they reach back to events so terrible that we can hardly believe someone could have lived through them, and forward, to the future, where young people live. They hope to change us into slightly different people from the ones we were before. They want us to be braver than we usually are and give more of ourselves to protecting whoever is being singled out today for cruel treatment. I know these things because when I was brave enough I asked what caused them to act in this way, and sometimes, when I didn't ask, I saw the answer later in the books they have written.

${ }^{49}$ Liba 21. 
I saw other people there too, visitors to the museum like me. I saw that each of us asked our own questions. One woman, also from New Zealand, asked a man if he had a number tattooed on his arm. No. A girl of fourteen asked a man what he would say to Hitler if he met him now. They wouldn't let me near him, the man said, and in that moment I saw him as dangerous. Did you ever see your parents again, asked a woman with her eleven-year-old daughter beside her. No.

It was four o'clock. Museums close at four o'clock. 'Tell all your friends to come here', one of the men said to me as we walked out of the gallery.

Missing from this account: her warm hands, his hand on my shoulder, his hold on my arm, his blue eyes, her brown eyes, two brown suits, dyed hair, lipstick, gold jewellery, natty shoes, one walking stick, quite a lot of kisses, my tears, her tears, his trembling chin. A comment about Australia - of course there are instances of anti-Semitism here too, but only by a few individuals - not the government. And her eyes, which became black, turned away from us, and saw things which she kept to herself.

I had known for a few years that there was a Holocaust Centre in Wellington. At the time of my first visit, in March 2012, the Wellington Holocaust Research and Education Centre was about to be re-launched as the Holocaust Centre of New Zealand. From its beginning in 2006 it had been housed in a room which opens off Myers Hall, inside the Community Centre, inside the Wellington Hebrew Congregation's building in Webb Street. On the street there is a flag inviting visitors to visit the Holocaust Centre, but, for security reasons, the door of the building is locked. Visitors are asked to ring a bell.

As a child of one of what Beaglehole and Levine call 'marginal and intermarried couples' only fifty per cent of me feels confident of a welcome in this place, but I ring the bell anyway. Inside I am warmly welcomed and invited to look around and ask questions. I look around. I notice that there are display cases telling the story of two of the survivors who came to Wellington. Their stories are told in four parts: 'Before', 'The Lead Up', 'What Happened' and then 'Their lives in New Zealand'. There are photographs of a particular day in 1985 when one of these women told her story in public for the first time. I meet a woman who was there that day, in the audience. I am glad that this first telling of the story to the public of Wellington is part of the place that tells the story of the Holocaust.

Hanging from a coat-hanger in its own glass case there is a dress given to a girl as she entered Auschwitz. It is made of heavy grey-ish fabric that looks like canvas. It has narrow shoulders and looks like a long shirt. I imagine this girl grown up, packing the dress into her suitcase when she came here. I imagine it folded, next to her sponge bag and her winter jerseys.

\footnotetext{
${ }^{50}$ Beaglehole and Levine. Far From the Promised Land 54.
} 
I talk about my interest in the Holocaust. I feel guilty because I haven't been to this place before but no one asks me why or makes me feel awkward.

I ask if anyone there knows the story of a wooden urn containing ashes from Auschwitz which were brought to New Zealand by a man called Karel Beran. I am given the name of someone in Auckland who has made oral history interviews with Holocaust survivors and might know the story of the man and the ashes and the urn.

I contact this person. She answers me the same day. She has known Karel Beran all her life. 'Karel did an interview with the Shoah Foundation and I think you will find it in the collection at the Alexander Turnbull Library if you would like to listen to him in person,' she says. ${ }^{51}$

On my second visit to the Holocaust Centre, when the subject of family comes up, one of the volunteers asks me if I have seen the Honours Board listing the names of all the members of the Wellington Hebrew Congregation who served in World War I or II. My grandfather's name is there, together with his two brothers, Ernest and Bertie. Bertie has a gold Star of David beside his name, indicating that he 'made the ultimate sacrifice'.

I come away from the Holocaust Centre with a list of books about the Holocaust written by survivors who lived or live in the Wellington area. In one of those books I see photographs of a family living in Palmerston North. They lived there in the 1980s and 90s as I did. They had holidays at Lake Taupo as we did. Their house was in a pleasant leafy street where one of my friends now lives. I go home and think about the space between the point of my nose and my chest which seems to house as many objects as a magician's hat. I wonder what I am missing today.

The re-launch involves moving to a bigger space with new display cases and space for researchers to work. The re-launch attracts a big crowd including local and national politicians and members of the Diplomatic Corps. The German Ambassador is here. I speak with a Jewish man who 'comes from' several countries in Europe. He tells me with some intensity, in English, that the German Ambassador ' must' be here. I nod. I think I know what the Jewish man means, but perhaps he is not convinced because he says it a different way and then another different way. 'The Ambassador does not choose to be here', he says, and then 'he does not want to be here'.

I think about the German Ambassador, who might rather be at home, and might like to be talking to his grandchildren by Skype, but is here, with hundreds of Jews, in Wellington, New Zealand, remembering the Holocaust again.

Yesterday I was talking with my friend in the museum industry about the re-launch. He is not Jewish. He told me that he had not known there was a Holocaust Centre in Wellington.

${ }^{51}$ Bruell, Claire. Message to the author. 7 Mar. 2012. Email. 


\section{The term for survivors of the atomic bombs is 'hibakusha'}

Akihiro Takahashi, a famous hibakusha, has just died. He was born in Hiroshima in 1931. As a schoolboy he wanted to be a pilot. This is how he explains the fact that he stood still, looking up at the silver body of a plane flying low over his school. This particular silver body happened to be carrying Little Boy. The bomb exploded about two kilometres from where he stood.

Mr Takahashi says that he should have died that day. He saw terrible things. If you have heard about this bomb before, you can imagine. He spent eighteen months in hospital being treated for his burns, and was left with an arm that would not bend, fingers on one hand that could hardly hold a pen and chronic liver problems. In those days Akihiro Takahashi, along with the other hibakusha, was looked on as something not quite human.

I do not know what he did in the years after he left hospital, but I know that in these years he hated Americans and called the bomb 'an experiment' where 'ordinary citizens [were] its guinea pigs'. ${ }^{52}$ But then, in 1978 he visited Pearl Harbour where he met relatives of people who died there. After that he said 'it is important to transcend hatred, to transcend the agony, to transcend the sorrow'. ${ }^{53}$

Akihiro Takahashi spent four years as director of the Hiroshima Peace Memorial Museum. There he guided visiting dignitaries and spoke to groups of school children. Over the years he told his story thousands of times. In 2002 he said this:

I tell myself that I'm a survivor of a terrible moment in history, and it is my belief that those of us who were saved should continue to talk of our experiences. We live to hand down the awful memories to future generations and represent the silent voices of those who died in misery and terror. ${ }^{54}$

Akihiro Takahashi had at least three lives. In the first he was a boy who wanted to be the pilot of a silver plane. In the second he was a man alive in hatred, agony and sorrow. In the last he was a man seeking to transcend the same things. Somehow it came to him that a man seeking to transcend hatred, agony and sorrow must pass on his memories and speak for those who were silenced. Perhaps one day, without meaning to conduct an experiment on himself, he just noticed that telling others something of his experiences left him with less hatred, less agony or less sorrow?

One article I read about Akihiro Takahashi mentions in passing a teardrop that may have rolled down the cheek of a man called Tibbets in 1980. Tibbets, a crew member of Enola Gay, the plane that dropped Little Boy, was sitting talking with Takahashi in Washington.

\footnotetext{
52 "Voice for the Silenced." The Christchurch Press. 31 Dec. 2011. Print. : B13.

53 Ibid.

${ }^{54}$ Ibid.
} 
That definitely happened. The two men held each other's hands. That definitely happened too.

Then Akihiro Takahashi says he saw a teardrop roll down Tibbets' cheek.

Tibbets says there was no tear. He was sorry that people burned up down there, he said, but it had to be done.

I choose to believe Takahashi.

A woman who survived Auschwitz wrote in her memoir that after she became a guide at the museum and regularly told her story there, her nightmares became less frequent. But, she says, it may not be the same for others. I learn from this woman that the effects of telling some of your own story over and over are particular to an individual. Later I learn from a different woman that these effects are mostly kept private. 
Your eye looked at me, looked away,

your mouth

spoke toward the eye, I heard:

We

really don't know, you know,

We

really don't know

what counts. $^{55}$

${ }^{55}$ Celan, Paul. "Zurich, at the Stork." Trans. John Felstiner. Qtd. in Paul Celan: Poet, Survivor, Jew. By John Felstiner. New Haven and London: Yale University Press, 1995. Print. 156. 


\section{How, exactly, will that happen?}

It has become a cliché for people to say that one reason for remembering the Holocaust is 'so that it won't happen again'. I always want to ask how, exactly, the act of remembering what happened, or passing that knowledge on, will stop it happening again. Yesterday, at the United Nations Holocaust Remembrance Day, three of the speakers described how they thought the mechanism might work.

One man, a politician, said that we should all step in to stop any extremist ideas from becoming established. Once established, extremist ideas develop their own momentum and become almost impossible to stop, he said.

Another man, a Māori leader, came up to the microphone in a puff of wind from the pine trees. He was at school here in Wellington with a man whose family came to New Zealand from Germany. That man was also at the ceremony. We didn't think of this when we were young, the Māori man said. He said that what he remembers best about the past is what the old people told him when he was a boy. Stories, he called them. Young people aren't going to read all this in books, he said. They might learn some things from a movie. But the best way to pass on to them what happened, is stories, stories, stories.

The last man to speak, a Jewish leader, began by saying how grateful Wellington's Jews are for the Council's action in repairing damage done to Jewish headstones in 2004 . We should all take away from this day the idea that the world is an imperfect place, he said. Our job is to try to improve the world around us - even if this is improvement is in small ways.

I have been thinking about the place of writing and of books in all this. A book could, perhaps without the writer's intention, contain old pieces of extremist ideas, broken down into tiny grains, worn smooth from all the times they have been handled. These grains could emit a high-pitched whistle, which members of a particular group hear and experience as very unpleasant, but most people, perhaps including the author, do not hear. 


\section{Belonging to the tribe}

I came across Michael King's At the Edge of Memory: A Family Story, ${ }^{56}$ at my mother's house. She told me she had found it very moving. She also told me she thought it was a bit 'light'. I inspected it.

The cover blurb of King's book described the book's content and likely appeal.

A man turns up in New Zealand in the early years of the twentieth century, as if out of nowhere. He admits to no past, only to a present and a future; and he reinvents himself as a Catholic businessman. But the pressure of keeping a secret, of having to live with a repressed truth, eventually becomes too great. He disintegrates, emotionally and physically, leaving his family sparse clues as to his origins and identity.

At the Edge of Memory will have a powerful resonance for all families whose ranks have been scattered by persecution or migration; it also casts a disturbing light on the specifically Christian ingredients of anti-Semitism.

The man who turns up in New Zealand is King's great-uncle by marriage. He lives his life as a businessman in Hamilton under the name Maurice Belgrave. As far as anyone knows, Bel, as he is known, never makes contact with his family back in Europe. My great-grandfather, who also popped up in New Zealand, alone, and settled in Wellington, did not, as far as anyone knows, make contact with his family again either. This parallel intrigued me, as it had my mother.

I put the book aside to read in the evening. During the day I was occupied with "A Report to an Academy ${ }^{\prime \prime 57}$ (one of Kafka's short stories) and John Mulgan's Report on Experience. ${ }^{58}$

Franz Kafka's story was published in 1917, in German, in a monthly magazine called Der Jude. Martin Buber, a scholar of Hassidic lore and philosopher who survived the Holocaust because he went to Israel in 1938, was editor of this magazine. Kafka, who wrote in German, selected Martin Buber and this magazine's readers as the audience for his story of an ape who forced himself to live like a man. This tells me that Kafka thought the story would speak in a particular way to Jewish readers.

Kafka's story concerns an ape, captured by humans, who learns to behave like humans. The ape has been invited to a learned academy to tell his story. Kafka's ape is very polite.

First he thanks the honoured members of the academy for inviting him to give an account of the life he formerly lived as an ape. Unfortunately, he says, he cannot provide that. 'I could

\footnotetext{
${ }^{56}$ King, Michael. At the Edge of Memory: A Family Story. Auckland: Penguin Books, 2002. Print.

${ }^{57}$ Kafka, Franz. "A Report to an Academy." Trans. Tania and James Stern. The Complete Short Stories of Franz Kafka. London: Vintage Classics, 2005. Print. 250-262.

${ }^{58}$ Mulgan, John. Report on Experience. Wellington: Victoria University Press, 2010. Print.
} 
never have achieved what I have done had I been stubbornly set on clinging to my origins, to the remembrances of my youth, ${ }^{59}$ he explains.

The ape did not begin with the goal of acting like a man. At first, after his capture, he sobbed hopelessly for his condition. But then he noticed that these men were free to move around while he was a prisoner. Aiming for even a limited degree of freedom, and with no promise that he would be treated like a man even if he acted like a man, he set about trying to do what men do.

One of the hardest lessons for the ape was learning to drink schnapps. I think back to the assimilation of Maurice Belgrave and wonder which part of life in New Zealand was hardest for him to learn.

As Mulgan says, talking of a time just before war was declared, 'You could forget Poland: it was a long way away. ${ }^{60}$

Maurice Belgrave forgot Poland, or whatever was his own Poland, for a long time.

Early in the book King describes the incident that caught his interest and triggered the writing of the book.

Maurice and Margaret had in their household a woman named Annie Jones, nicknamed Ciss, who acted as housekeeper and child minder. In August 1943, Ciss had come upon Maurice in his living room. He was listening to a $\mathrm{BBC}$ radio programme with tears glistening on his cheeks. On air a journalist was speaking about Nazi extermination camps in Eastern Europe and the fact that the majority of inmates and victims were believed to be Jewish. "Those are my people" a griefstricken Maurice told Ciss. He was already seriously ill, suffering as he had been for some years, from the effects of diabetes. Days after hearing the broadcast he was dead from a heart attack. ${ }^{61}$

King hears about this incident from his mother and from that point on, he is interested in the idea that Maurice Belgrave was probably Jewish. He is interested enough in this to take some opportunities to investigate the origins of the man he knew as Maurice Belgrave.

I started At the Edge of Memory at night, finishing it around 2 am. At 165 pages, including 24 pages of photographs, it is a short book. I remember that, as I read, there seemed to be a veil between me and the heart of the story. I thought I could feel a heart there, under some layers. Sometimes I seemed to catch a glimpse of it, beating, but mostly I was unable to see

\footnotetext{
${ }^{59}$ Kafka 250.

${ }^{60}$ Mulgan 75.

${ }^{61}$ King. At the Edge of Memory 26.
} 
it or feel its presence. That night I had a dream. Without the dream, I would have returned the book to the library, and thought of it as a story that never really happened.

Rather than forgetting the dream on waking, as I usually do, I found myself remembering it more distinctly as I set out on my morning walk. It seemed as though the act of walking in the cool morning air somehow made space for the dream, before the bright light and noise of the day could wash its colour away.

In the dream I was visiting or in some way amongst a group of brown-skinned people, living a certain way, under the leadership of a sort of guru. They all wore blue robes that fell to the ground. Their way of life was complicated - there were lots of rules and prohibitions. Their rules had one purpose, to make their lives gentle on the earth and on each other. I was my usual self, the way one usually is, in dreams.

For some reason I crossed into another group of people. Maybe I was just slow and was left behind as the others moved? Maybe I went away on purpose? These new people were tough and nasty. They had white skin. I took off my blue robes. Without the blue robes I looked like these new people, or they looked like me, and I was able to move amongst them. I heard them talking about their plan to attack all the blue-robed people and kill them. I went to warn the blue-robed people. I was amongst them when the killing started.

I started At the Edge of Memory again next morning, looking for the connections with the dream. This second reading was a very different experience.

As I read the book this time I experienced an increasing sense of mistrust and unease at the actions of the author, which culminated in a rebellion against his power during Chapter Five, 'Voices from Europe'. 
King's book is in the form of a memoir. In the Author's Note, King explains his choice of the memoir form.

Like so many true stories, and like life itself, the story [of the arrival of this stranger on a quest] has gaps that can be bridged only by supposition. Hence the memoir form in preference to conventional biography; and hence the title. The whole narrative arises from the edge of memory rather than from a central foreground of finely focused documentary evidence. ${ }^{62}$

I have been warned. I will not find a biography of Maurice Belgrave. I will find excavation of memory. If the life of Maurice Belgrave is found at all it will be near the place where memory turns into nothing. I am interested in this place. In nothing.

${ }^{62}$ King. At the Edge of Memory 10. 


\section{Home}

When I was first starting to learn about the Holocaust, I remember being preoccupied with the problem of how I would know when it was time to leave New Zealand. I would read about people whose lives were deeply rooted in a certain place in Europe. More deeply rooted than mine felt. I saw pictures of these people, captured in a moment in 1932 or 1936 , by street photographers, as they walked in pairs along a street with a German name. So stylish. So confident-looking. This is Before. Sometimes Just Before, like the photograph of Paul Celan turning to look behind him in Czernowitz, in 1937 or $1938 .{ }^{63}$

I do not mean to suggest that these photographs lie. These people did walk arm in arm and the sun shone on them. Their clothes were more stylish than ours. If you look, you can even see hard times in the background of the photographs, like one I saw yesterday, which showed a woman in a dark-coloured coat with white plaited detailing and a feathered hat, striding along a street in Czernowitz. She is looking straight ahead in a rather fixed way, which may or may not be related to the fact that she is walking past a boy with ragged pants and no shoes, standing in a doorway. ${ }^{64}$

But by the time of this 1937 or 1938 photograph Paul Celan had already transferred from one high school to another because of anti-Semitism. He and his friend liked to lie in the shade of a tall tree reciting Rilke to each other, but they never went far because that would have been 'too risky for two Jews in Romania of the $1930 s^{\prime} .{ }^{65}$ In 1938 Celan left for university in Paris, spending money his father wanted to spend on the whole family's emigration to South America. The young Celan's train, full of all sorts of people, passed through Berlin at the moment of Kristallnacht.

you caught sight of some smoke that was already from tomorrow ${ }^{66}$

Before [nice pictures] During [not the same person, shaved heads, striped clothes, thin bodies who could be anyone] and After [normal looking people or wild, saddened people]. It's one of those set pieces.

\footnotetext{
${ }^{63}$ Felstiner, John. Paul Celan: Poet, Survivor, Jew. New Haven and London: Yale University Press, 1995. Print. 9.

${ }^{64}$ Hirsch and Spitzer. Ghosts of Home 69.

${ }^{65}$ Felstiner 9.

${ }^{66}$ Celan, Paul. Gesammelte Werke. Ed. Beda Allemann et al. Qtd. in Felstiner 11.
} 
As a younger person I spent time looking at Before photographs trying to see if they knew it was time to leave. I thought I would see a darkening in people's faces, or perhaps an expression that said they knew it was already too late. But I didn't. Or maybe I did, but I didn't recognise that expression.

'Backshadowing' is one word for what I was doing, reading the past backwards, and using this information to 'judge the participants in those events as though they too should have known what was to come. ${ }^{67}$ I find myself guilty of asking these questions: Should they have known? How could they not have known? And, at the same time, who could have guessed?

'Paranoid reading', 68 a term used by Eve Kosofsky Sedgwick, speaks to my eagerness to find violence and danger hidden in these photographs before violence and danger reveal themselves, if they are there at all. If I find the bad stuff before it finds me, I cannot be taken by surprise. Paranoia is anticipatory, she says, and also 'tends to be contagious'. ${ }^{69}$

\footnotetext{
${ }^{67}$ Bernstein, Michael André. Foregone Conclusions: Against Apocalyptic History. Berkley: University of California Press, 1994. Print. 16.

${ }^{68}$ Kosofsky Sedgwick, Eve. "Paranoid Reading and Reparative Reading, or, You're So Paranoid, You Probably Think This Essay Is About You." Touching Feeling: Affect, Pedagogy, Performativity, Durham, N.C. : Duke University Press, 2003, Print. 123-151.

${ }^{69}$ Kosofsky Sedgwick 126.
} 


\section{A tchemodan}

As far as I can see nothing answers the question of how Jews were supposed to know when it was time to leave Europe. I think this unanswerable question is the reason that I, a full citizen of New Zealand, have inherited a sensitivity, common among Jewish people, to suitcases.

1. Ernst Toller had two suitcases.

2. Michael King's great-uncle by marriage, Maurice Belgrave, who was also called Moshe Belgoraj, began in business by taking two suitcases of fabrics, buttons, needles and thread onto the Auckland to Wellington Express and selling from the aisles.

3. Rose Ausländer only owned two suitcases in her life. They are in a museum now, in Düsseldorf.

4. Jacques Austerlitz had a rucksack, which he describes as 'the only truly reliable thing ${ }^{\prime 70}$ in his life. Sebald provides the reader with a picture of it.

5. I'm sure I heard that Jews living in Germany since the war have an expression which means 'living on top of their suitcases'.

6. At the Wellington Holocaust Research and Education Centre I saw thirty important books set out on a table. One had the word 'suitcase' in the title. Two had images of suitcases or rucksacks on the cover.

7. The newly re-launched Holocaust Centre of New Zealand now has two suitcases amongst its displays. One belonged to a man who, as a child, was sent away on the Kindertransport trains. The suitcase was the last thing his mother gave him. Inside the suitcase she had placed a list of every item of his clothing.

8. A Jewish man arrived in Australia after the war with only one suitcase. His friends laughed when they saw that the suitcase was full entirely of books in Yiddish. The Communist Manifesto. Anna Karenina. One suitcase and he could be at home anywhere. Home enough, anyway.

Last night I went to a lecture where I heard that our breath is our real and only home. I like this idea. I already know that you can reduce what you own until it fits into one suitcase and then that suitcase feels like your home. That is the world of exile and the world of the traveller. But perhaps you can throw away the suitcase and still have a home? I try out this idea. I breathe in. I am alive. I breathe out. I am home. I think about what home is.

\footnotetext{
${ }^{70}$ Sebald. Austerlitz 40.
} 
I miss my childhood, an old man I met said, but I do not miss Poland.

His childhood // in Poland. He pulls these carriages apart.

A fictional man, one Bloomfield from Carlton, looks back from 1958 to Poland in the time before. He remembers a season called 'Golden autumn':

... the time of haybales and tired farmers making their way back home. The thatch upon village cottages trapped the setting sun within its folds. On the rooftops stood bociany, storks, erect in their massive nests. Bociany is Bloomfield's most loved Polish word. And storks perched upon thatched cottages, on guard, beside their nests, remains his most loved image of the time before. ${ }^{71}$

Bloomfield had two daughters in his nest. They were sent to the left, he to the right. One day in Carlton, a suburb of Melbourne, he sees leaves blown against a wire fence as a man impaled on an electric fence. Bloomfield falls to the ground, sensing guns pointed at him by the guards high above him in their watchtowers. As the sun finally sinks Bloomfield sees only leaves again and wonders if storks are on their way.

${ }^{71}$ Zable, Arnold. Scraps of Heaven. Melbourne: Text Publishing, 2004. Print. 81. 


\section{Thinking about waves}

People who live right beside the sea, as I do, think about waves. Sometimes it takes the form of 'lingering subconscious awareness of the slowly rising tide that would one day prise my house off the ground and sweep it out to sea. Or the giant wave that would lift it up in one quick rolling thunder. ${ }^{72}$ You ponder, as Olsson does, which fate you would prefer. You compare the odds of the giant wave with being hit by a bus while crossing Lambton Quay. You find reassurance in the fact that the house has stood in its seaside location for fifty years. You try to convince yourself that you accept your fate, that you are ready. As far as I know, everyone thinks about giant waves in these ways but I don't know anyone who has moved house or done anything practical as a result of those thoughts.

If a wave the size of a fence came and I did not have insurance on my house, a radio, a torch and enough medication, canned food and water for three days stored in the garage, people would be shocked and disapproving. A wave the size of a fence is not only a known risk, it is an imaginable risk.

72 Olsson, Linda. The Kindness of Your Nature. Auckland: Penguin Group (NZ), 2011. Print. 11. 


\section{A lexicon of risk}

Varieties

Real Risk

Insurable Risk

Commercial Risk

Raw or Untreated Risk

Statistical probabilities

Rare

Unlikely

Possible

Likely

Almost certain

Activity

Identification

Analysis

Evaluation

Priority ranking

Treatment

Acceptance

Communication

Calibration

Possible

Optimistic

Probable

Conservative

Worst case

Consequences

Negligible

Minor

Moderate

Major

Severe

Ruinous 
Recently I received a letter outlining likely changes in the Kāpiti coastline over the next hundred years. 'Coastal Erosion Prediction Lines' showed the sea lapping, or clawing, at my letterbox in 50 years.

On its way to that predicted line, the sea will have taken 100 metres of sand dunes, a row of houses and a tar-sealed road.

Coastal erosion prediction lines $=\mathrm{LT}+\mathrm{ST}+\mathrm{SLR}+\mathrm{DS}+\mathrm{CU}$, where

$\mathrm{LT}=$ longer term historic shoreline change

ST= shorter term shoreline fluctuation

$\mathrm{SLR}=$ shoreline retreat associated with sea-level rise

DS= dune stability, and

$\mathrm{CU}=$ combined uncertainty

There is much discussion among residents about whether this is a likely scenario or only a possible scenario, this point having great significance for re-sale values. 


\section{Researching Bolechow ${ }^{73}$}

Daniel Mendelsohn is an energetic and thorough researcher. He makes use of family photographs and their captions. He reads old letters. He looks between the lines. As he goes along he meets a man in Israel who is keeper of all information about Bolechow's Jews. This man tells Mendelsohn the names of people who might know something that could help him fill in his white space. When Daniel hears of old people who might know something about his great-uncle and his family he crosses the world to meet them. He interviews them carefully, keeping quiet about what he already knows so that they will tell him what they think is correct.

He asks them endless detailed questions. Sometimes these meetings involve him in eating enormous meals which elderly ladies have cooked, despite their failing health, because they knew he was coming to talk about the old country. He records all these interviews. He brings his brother, a photographer, along so that he will have a photographic record. That brother is willing to ask two elderly men to sit in a car for twenty minutes, roll up their trousers and walk into the sea at Bondi Beach, and then ask a surfer to walk backwards and forwards behind the two men because that would be the best photograph of Holocaust survivors in Australia.

'My job is playing bad cop to people until they reach the breaking point. I need a picture that says "Australia", otherwise why did I come?" he says. ${ }^{74}$

Sometimes, as I read Daniel Mendelsohn's book, I worried about these elderly people he was interviewing. I wondered who would help them with the dishes after he left and whether they would be able to sleep. Maybe they stayed drunk for three days after his visit, or had a heart attack? I wondered if he ever stopped before he had finished his enquiries, just because it would be considerate.

I thought that if it were me, I would rather miss something important than dig deep like a surgeon. I would rather lose a photographic edge than ask an old man to get his feet wet.

Mendelsohn thought at first that Bolechow existed only in frozen form in the remote past. During his research he found that people from there were present, pinching his cheek and staring at him, at family parties during his childhood. At that time he hid from them, finding them weird. Bolechow is Bolekhiv now. At present it is in Ukraine. Mendelsohn met people there who had lived in both Bolechow and Bolekhiv.

\footnotetext{
${ }^{73}$ Bolechow was a village near Lemburg [now L'viv] 'in the province of Galicia in the Imperial and Royal Empire of the Dual Monarchy of Austro-Hungaria' (Mendelsohn 65). I use the old spelling 'Bolechow' when speaking of Mendelsohn's quest.

${ }^{74}$ Mendelsohn. The Lost 257.
} 
Sometimes, in the midst of his 512-page text, Mendelsohn inserts the word 'Listen'. One such imperative appears on page 64. I am not sure what makes him decide to address the reader so directly. I wonder if perhaps his grandfather used to say this to him. Or whether, for just that moment, he finds himself unable to stay behind the curtain and feels compelled to address us in this way? 


\section{Anglo-Celtic eyes}

Researching his own memories as a context for Maurice Belgrave's abandonment of his Jewish identity, Michael King searches for anti-Semitism in New Zealand and finds it.

In Chapter One, as the mystery of Maurice Belgrave's life is being laid out, King's mother says that the New Zealand Maurice Belgrave/Moshe Belgoraj arrived in was anti-Semitic or at least xenophobic and so creating a new identity was understandable. She reminds her son about the furriers she worked for as a young woman and the 'sharply derogatory' ${ }^{75}$ comments staff made about them based on their Jewishness.

In a rather disingenuous ${ }^{76}$ device, King has his mother remind him about From Europe to New Zealand: An Account of Our Continental European Settlers, a book by Reuel Anson Lochore. This book, King says, revealed 'prejudices' about 'New Zealanders of non-British origin, especially those of Jewish descent' ${ }^{77}$ These prejudices, King says, were 'representative of those held throughout the country at the time' (the 1950s). King describes Lochore as:

a retired diplomat who had taken me under his mentorial wing in the mid 1970s, when I had embarked on a career as a fulltime writer. He was erudite, with degrees in languages, literature and philosophy; and he was kindly. ${ }^{78}$

In Chapter Two, King re-tells a story a priest told him. The priest's father always dressed up for the local A\&P show as 'Ikey', a man in robes, with a long nose. King concludes:

There was no racial malice involved - simply an assumption that this was what Jews looked like, and that they were different and amusing in Anglo-Celtic eyes. ${ }^{79}$

I react immediately and adversely to this sentence. I do not find this Poverty Bay Shylock amusing and I do not buy King's verdict that there was no racial malice, which I would call anti-Semitism, involved. As he says this I realise that I do not have 'Anglo-Celtic' eyes, or at least not in the sense he means.

In the next paragraph King tells us that this same priest talked to him about finding Protocols of the Elders of Zion in the seminary library. This book, as King says, 'was a notorious forgery by the czarist (sic) secret police designed to discredit Jews and add momentum to anti-Semitism in Russia'. ${ }^{80}$ I notice this title as I would a gunshot in a drawing room, and after this I read even more closely to see who touches the Protocols of the Elders of Zion and what they say about it.

\footnotetext{
${ }^{75}$ King. At the Edge of Memory 28.

${ }^{76}$ King had written about Lochore in some detail in Metro in 1991.

${ }^{77} \mathrm{King}$. At the Edge of Memory 29.

78 Ibid.

${ }^{79}$ Op. cit. 40.

${ }^{80}$ Ibid.
} 
I see that King and I agree on the need for this analysis because he points out that there was no note with the book in the seminary library to say that it is a notorious forgery. King distances himself from the book by saying this, although in fact I have never seen a note in a book, warning readers that it is a forgery or that it may incite hatred. The priest, who has spoken about the book but is not reported as having distanced himself from it, and whose father dressed up as Ikey, is left in a more ambiguous position.

In later sections of this chapter King recalls the time when he was fourteen and he heard a man call a girl a 'greasy little Jewess'. ${ }^{81}$ The girl was someone he knew from skiing. She was beautiful and sporty and always skied with one boy. The man who said these words was the boy's father, 'a respectable Wellington businessman, a good family man and generous contributor to community projects who had served in the Second World War'. ${ }^{82}$

'Who, then, were the anti-Semites?' ${ }^{83}$ King asked himself when he was fourteen, following this question to the shocking possibility that here, in New Zealand, there might be people who condoned or even supported what Hitler had done. The young Michael King was, in his own words, 'astonished', 'appalled' and 'struck dumb' ${ }^{84}$

King says that learning of the extermination of European Jews, during his childhood, with all the associated images from the camps, affected him profoundly.

At this time I lost the ability to laugh at any joke, however harmlessly intended, that poked fun at or caricatured Jewish behaviour, he says. ${ }^{85}$

My distrust of King as a narrator of stories touching the Holocaust began over the problem of how all the pieces fit together: all the statements of sympathy, amusing Ikey in Gisborne, the 'kindly' author of From Europe to New Zealand: An Account of Our Continental European Settlers, and Protocols of the Elders of Zion.

In Chapters Three and Four, King visits New York and meets David Belgray, a psychoanalyst who has devoted his life to finding and re-connecting lost members of the Belgoraj family. David Belgray's path to all this began with his uncle Manny, who 'used to recite the names of our grandparents and our aunts and uncles in an almost biblical fashion, who begat whom and so forth. ${ }^{86}$ As a young man David Belgrave received this as an evocation of a long-departed life, which he associated with visits to the apartments of old people and strange cooking smells. But, eventually, he wanted to know what it all meant.

\footnotetext{
${ }^{81}$ Op. cit. 44.

82 Op. cit. 45.

${ }^{83}$ Op. cit. 46.

${ }^{84}$ Op. cit. 44.

${ }^{85}$ Op. cit. 46.

${ }^{86}$ Op. cit. 64.
} 
By the year 2000, when David Belgray phoned Michael King, he had been on this quest for about 45 years and had compiled a family tree with more than 1200 names on it and another 1000 waiting to be entered. David Belgray had known of a possible link in New Zealand since he met Erna Winton, a cousin from Australia, at a family reunion in 1985.

For David Belgray the important thing was that the people at the reunion had always felt as if they were 'remnants of a small clan dispersed by the Diaspora and ravaged by the Holocaust', but they could now see themselves as part of 'a large, living and loving family with a rich cultural heritage ${ }^{87}$ It was good for people to feel this, he believed. It might even be good for King's health, he says, to see and experience something of the culture in which Bel had grown up. David Belgray dresses King in a yarmulke and sends him on his way to a synagogue to soak up some old-world Jewish atmosphere.

King enters an ultra-orthodox synagogue in Borough Park Brooklyn, alone. 'It might as well have been another planet,' King says of the scene which greets him. ${ }^{88}$ Sounding like a lone Englishman of the Victorian era, surveying a tribe of natives, King describes his impressions and his plan:

I understood neither the forms nor the content of these complementary forms of worship and reflection. And I did not seek out anybody to interpret for me precisely what was going on, for two reasons. One was that I did not want to impede or interrupt the participation of any member of the congregation. The other was that I had not gone there in an analytical or anthropological frame of mind. I simply wanted to see, hear and experience forms of ritual that would have been part of my great-uncle's shtetl upbringing. ${ }^{89}$

At first, King, the outsider who does not participate, is ignored except for some hostile glances from a group of young men. But when he starts writing notes an older man comes over and says quietly that King should not write but he is welcome to stay and observe as long as he obeys their customs. King apologises and puts the paper and pen away.

After this a number of men of about his own age come over and sit with him for a few minutes. They ask him, in a friendly way, why he is there. King tells them about his search for understanding of his great-uncle's decision to come to New Zealand and to change his name and identity. They are interested in his search and tell him about their own searches and their links to particular shtetls, but there is a big difference between Maurice Belgray's story and theirs. Their families have maintained their Jewishness and they are proud that so much of European Jewish culture from before the 1930s still exists in their part of America.

\footnotetext{
${ }^{87}$ King. At the Edge of Memory 76.

${ }^{88}$ Op. cit. 79.

${ }^{89}$ Op. cit. $81-82$.
} 
One of the men, Bernie, says that he feels 'an obligation to preserve in America precisely what had been lost in Europe'.$^{90}$ He believes they should retain their Jewish identity by keeping their families inside a purely Jewish world, inside the secular society. The Shoah ${ }^{91}$ tells him that.

But then Judah, a man in his fifties, comes over and begins 'what felt like an interrogation' about King's reasons for visiting. 'To my shame', King says, 'I decided to tease him, curious about what that might bring to the surface. ${ }^{, 92}$

A religious debate follows. It ranges testily over several issues before Judah says that it is possible that assimilated Jews caused the Holocaust. Perhaps if they had stayed in the Jewish world and not been so visible, Christians might not have been provoked into attacking them? Perhaps God produced the Holocaust because so many Jews were abandoning their laws? These are views which must be considered, Judah says.

King disagrees with this, and says so, firmly, calling Judah's question 'wrong-headed and brutal'. ${ }^{93}$

Judah accuses King of cultural tourism. King feels uncomfortable and leaves.

I can hardly believe that someone would go into an unknown culture, tease someone about it and then write about that.

In Chapter Five, King interviews Erna Winton, an elderly Jewish woman who is Moshe Belgoraj's niece. Throughout this chapter King takes up a sort of commentary position, as he did in the synagogue in Chapters Three and Four, but this time it feels more critical than anthropological. Parallel with this he describes his own actions.

According to King's account of what happened, he phones Erna (that is her Australian name) from his Melbourne hotel room. She is deaf. He asks if he can visit her. She says he can come the next morning. He arrives at the house. He points out that Erna's front path is overgrown with weeds.

She does not answer the door when he knocks, so he bangs on the front door with his fist. When she appears down the side path, he tells us that she has a face like a Pharaoh and that she says the word 'wait' as 'vait'. She has rolled up rugs behind the front door and he has to push really hard to open the door, he says.

\footnotetext{
${ }^{90}$ King. At the Edge of Memory 85.

${ }^{91}$ Bernie uses this Hebrew word meaning 'catastrophe' instead of the English 'Holocaust'.

92 Op. cit. 86.

${ }^{93}$ Op. cit. 89.
} 
According to King, Erna is delighted to have the chance to tell her story. No one has asked her to do that before, although Spielberg ${ }^{94}$ has already collected her husband Rudy's story because he was in the camps. King points out her German way of pronouncing the name Spielberg, and then he lets her start.

She is young and beautiful. More beautiful than her sister. She is clear about this. She plays the violin and has ambitions for a career in music. She and all the other young ones are modern and cultured. They speak German. The old ones are devout and scary. They speak Yiddish. There are fields of wheat and peasants, wolves, of course, and snow. The old man, Moshe's father, has a whip. Two of his sons go to New York to get away from him. One of those sons goes as far as Hamilton, New Zealand where, according to family rumour, he had black children.

Erna's story promises to be interesting, with a grim old man and his runaway sons as the researcher's treasure and her own story, the one she knows best, as a bonus. But I never really get to hear her story because King, the author, stands between me and Erna, getting in the way all the time. Sometimes he is just there, occupying space that I wish Erna was occupying. Sometimes he makes comments from the side about Erna, telling us that she is suffering somewhat from dementia, or that in his opinion she was beautiful. I get fed up. I can take it no longer. I quit as the compliant reader of his book. I begin something new. Whatever it is that I am writing it will have different rules from this book.

I write a play. I call it And also it was cold there in the winters. In the play, nearly everything is exaggerated.

King appears as a sort of Kafkaesque Judge, with Erna his target. The rugs, the weeds, her nose, the accent and her claims of beauty are her crimes. Everything she does makes her guilty of being old, from Europe and a Jew. I take pieces of Michael King's text to use as his voice. This seems fair.

I appear as a somewhat violent person who is very touchy on the subject of the Holocaust. I warn King that he is being judgemental about Erna. I ask him nicely to let Erna speak. He does not change his approach, so I gag him with a clean white hanky. After that we all sit still and listen to Erna's story for as long as she feels like telling it.

Erna appears as an elderly Jewish woman with two names. Erna is her Australian self. Esther is her Jewish self. She has lost many of her family and spent nearly fifty years married to a man who was in Dachau and Buchenwald and lost nearly all his family. She is still beautiful and exactly as crazy as everyone else.

\footnotetext{
${ }^{94}$ She means through the Survivors of the Shoah Visual History Foundation.
} 
She is a bit deaf to New Zealand Anglo-Celtic English, but hears perfectly in German, Yiddish, Hebrew, Polish, Russian and Romanian. She talks for four hours in English, with the occasional word of German and Yiddish thrown in as delicious seasoning.

Mostly she talks about herself. Where possible, I use her words from King's book. Sometimes I have to guess what she would have said, based on bits and pieces that King mentions but does not elaborate on.

This is what I add. There are plenty of wolves and sleigh rides and Erna has a valuable violin because she deserves it. There are some anxious and hungry years during the war and just after in what was then the British Mandate of Palestine. There is a search for family left behind in Europe and many letters from the Red Cross which make her cry. There is a romance with a man who dresses well but is alone in the world and then there are two suitcases and a ship which docks in Melbourne.

My version of Erna's story and King's are not always interested in the same things, but at one point in King's story, and in mine, Erna says that her mother knew her brother Moshe Belgoraj, as she called him, was in New Zealand and wrote to him in 1938. She received this answer from his wife:

My husband does not wish to communicate with his relations. Please do not attempt to contact him again. ${ }^{95}$

Erna's mother believed her and never tried again. Erna also tried to contact the family in the 1950 s or 60s while she was on holiday in New Zealand. She phoned a Belgrave from the Hamilton directory but the man told her he hadn't heard of her and hung up.

In the book and in the play Erna dies a few days after King's visit. On the day of his visit no one knows that she will die so soon.

${ }^{95}$ King. At the Edge of Memory 100. 


\section{This Crazy Thing a Life}

As a direct result of all my reading, I make up ten rules to guide me in my own research.

1. I will not phone deaf old ladies out of the blue. I will arrange to be vouched for, and introduced.

2. I will not bang on people's front doors with my fist, or any metaphorical version of that.

3. I will try to recognise Yiddish words.

4. I will answer questions about my parents, my marital status, number of children, their degrees and their incomes, without flinching.

5. I will make sure I always have a clean hanky.

6. I will try to say German words correctly.

7. Schpielberg is the correct pronunciation of the name of the movie director.

8. I will not interrupt old people when they are telling me their story, except if there is a fire alarm.

9. I will not cry unless they do.

10. If they are women, they were beautiful when they were young.

After I find a book with the title This Crazy Thing a Life ${ }^{96}$ I add Rule Eleven: Life is crazy. People are getting by.

Much later, having noticed the contributions made by Billy Pilgrim, the Tralfamadorians, Jacques Austerlitz and Bloomfield of Carlton, I add two more rules, these to be applied ex post facto.

12. It is important to find out things but even more important to avoid harming natural people.

13. Fictional people do not look you in the eye or feel pain. They are available without appointment, and at very little expense. Furthermore, their well-being is not of concern to any official bodies. They therefore make excellent research participants, and will be considered whenever possible as a preferable alternative to natural people or the natural descendants of dead people.

\footnotetext{
${ }^{96}$ Freadman, Richard. This Crazy Thing a Life: Australian Jewish Autobiography. Crawley: University of Western Australia Press, 2007. Print.
} 


\section{Good clean fun}

From the first moment I wrote down my reservations about Michael King's At the Edge of Memory, I have been aware that for academic and ethical reasons, I would eventually need to say clearly whether or not I mean to accuse this writer of being unable to 'see' or 'hear' anti-Semitism in himself or others.

To be entirely honest, after several readings of the book, I am still not sure if I was a bit insane to become so angry while reading it. The gunshot-in-the-drawing-room books, Ikey in Gisborne, King's behaviour in the synagogue and his somewhat judgemental tone in describing Erna are in his book. I have not imagined them and I am still disturbed by them. But I could not find again, on the third and or the fourth readings of the book, the fire that burned hot enough to make me spend several weeks during the summer of 2010/2011 writing And also it was cold there in the winters.

So I did what I always do. I read more. I read Reuel Anson Lochore's book. I inspected the card inside the back cover to see who from the old Wellington Teacher Training College or the present Victoria University had borrowed this book before electronic issuing removed this trail. In fact I was still reading this book when it was requested by another reader, so I know it does not live ignored in any dark stack.

I read an article King wrote about Lochore in Metro magazine in $1991,{ }^{97}$ nine years before he wrote At the Edge of Memory. After this I am sure his mother did not need to remind him of this book. I also read some comments by Paul Spoonley ${ }^{98}$ about the relationship between Lochore, King and a man called Fred Turnovsky who had been interviewed by Lochore when he applied for New Zealand citizenship in 1945. Lochore had been hostile enough in this interview to lead Turnovsky to research Lochore's activities in some detail and write about it all 50 years later, in 1990. Lochore's book and an earlier unpublished version struck Turnovsky as similar to publications in Germany in the 1930s which set out to show Jews in 'the worst possible light'. ${ }^{99}$

I find a few more smoking guns: Lochore was involved with sponsoring a visit to New Zealand by a German, Count von Luckner, in 1937 and spent a week with storm troopers in Germany. These activities had raised questions at the time in New Zealand newspapers about whether Lochore was a fascist.

\footnotetext{
${ }^{97}$ King, Michael. “The Strange Story of Reuel Anson Lochore.” Metro (NZ) 117. March (1991): 114-125. slaw.vdxhost.com. Web. 14 May 2012.

${ }^{98}$ Spoonley, Paul. "Anti-Semitism at the End of the World: The Politics of Prejudice in New Zealand." Jewish Lives in New Zealand. Ed. Leonard Bell and Diana Morrow. Auckland: Random House New Zealand, 2012. Print. 231-232.

${ }^{99}$ King. “The strange story of Reuel Anson Lochore." 123.
} 
In Metro, in 1991, King says that he finds Turnovsky's assertion that Lochore was antiSemitic 'plausible' and 'not without justification', but on balance he is not convinced by it. Not that Lochore didn't do those things, but King finds Lochore's sponsorship of the von Luckner visit naïve and possibly well intentioned, rather than supportive of fascism. Similarly he finds Lochore's opinions 'forthright and frequently foolish', but indicative of 'conservative inclination' rather than fascism or anti-Semitism. King speaks here with the confidence of a judge briefing a jury about which pieces of evidence they should take notice of and which they should ignore.

Spoonley includes Lochore in a chapter about anti-Semitism in New Zealand, but he does not reach a conclusion about Lochore's or King's views. He follows Turnovsky's and King's arguments and then takes his gaze from the various individuals to a comparison of New Zealand's immigration policy in the immediate post-war period compared with Australia's, and reflects on Lochore's influence on it.

Unlike Fred Turnovsky, I have no personal experience of Lochore or of being at the mercy of Immigration officials. I have not studied anti-Semitism in New Zealand as much as Paul Spoonley, but my conclusion is that there are times when Michael King shows that he can hear and see anti-Semitism. These are when the people involved are somewhat distant from him, such as the man who makes the 'greasy little Jewess' comment and when the situation relates to a 'large picture', such as the views of the Catholic Church in New Zealand in the 1950 s or 60s.

In the case of the writings and views of Reuel Anson Lochore, for whom King clearly had strong affection, King seems to equivocate and finally settles on foolishness or naïvety as the explanation rather than anti-Semitism. In the synagogue in New York, he thinks of his own actions as 'teasing' or fun where I would not. I notice that fun is also his explanation of Ikey from Gisborne. I think it is fair to ask if, in these situations, he can discern anti-

Semitism. It may be pushing the argument a bit far to bring this up, but I notice that a young man recently convicted of setting fire to another man at a party said in his defence that his actions were intended as fun. 


\section{Excuse me Madam}

One day in November 2011 I sat for an hour or more with a man who came to the museum on a certain day every week, to tell his story. As I walked through the museum I saw him talking with a middle-aged man, then I saw the middle-aged man walk away. I'm not quite sure what happened next but I remember thinking the old man looked very frail and saying perhaps we should sit down. He must have agreed because we sat down side by side on a padded bench seat and he started to tell me about how he survived.

This was the first time anyone ever looked straight at me and told me a story like this. I did not expect this situation to develop as quickly as it did and I did not stop him to ask if he would be willing to sign a consent form and to remind him that talking about the Holocaust might be upsetting for him.

At first I was his only audience. After some time two other women caught his eye. He stood up and walked towards them. 'Excuse me Madam, would you like to hear my story?' he asked. They joined us.

I noticed that his story proceeded in loops, coming back after lengthy movements to particular points. These points acted like the intersection of several important roads. From one of these crossroad points the story could go in several possible directions. This meant that if a new person arrived - something he strongly encouraged - he could carry on towards the nearest crossroad and then choose for the new audience which road to go down.

I also noticed certain concentrations of attention. The German man who shared news from the Eastern Front with him, and sometimes his sandwich, was one. The fact that the road he lifted stones for and the airport he carried wood for were never finished or used was another. His conscientious approach to work and the importance of staying out of trouble was another. The people he met and the things he did in the days just before and after he liberated himself were the last.

I suppose he would have many possible structures and concentrations, depending on who he was talking to. Bloomfield from Carlton, a fictional man who hardly ever spoke, used to visit a woman who had been on the same boat with him coming to Australia. A boat-sister, he called her. He would wait and watch until he thought all her family was out then slide along the hall and sit at her kitchen table. She would talk to him and no one else about voices and dybbuks which tormented her. He would intone the word 'Yes' in a strange singsong voice, over and over again. 


\section{The facts}

The notion of facts in relation to the Holocaust is very very important to people who survived it and to those who support them. They are afraid at the deepest possible level that the rest of us just will not believe that these things happened. Watching one day as a busload of burly fifteen-year-old Australians arrived at a museum with their teachers, to hear about the Holocaust, seeing their powder-blue blazers and the way the boys bashed into each other on purpose and laughed when someone was knocked off his feet, I wondered if they had it in them to hear about this.

I wondered if they would see the tiny white-haired man speaking to them in heavily accented English as an object of ridicule. But I had underestimated both the white-haired man and the fifteen-year-old Australians. For a few minutes, as the white-haired man in the very smart brown suit spoke about the complexity of political life in Europe in the 1930s it looked touch and go. But quite soon he started to tell them about his life in the Lodz ghetto and the job his father gave him - to build a hiding place for himself and his mother.

I could feel the atmosphere changing as he spoke about this. He told the students that one day his mother could no longer climb up into the hiding place. She said she intended to take a place on the transports. He told the students that he went with her to Auschwitz, hoping that he would be able to look after her a little.

At this point there was silence in the room. In the silence I looked around and noticed that the students were from many cultures. Who knows what stories of parting and love they had? A teacher sitting near me was crying.

Later the old man spoke about something he did which he was clearly proud of. He and a friend collected official posters listing all the restrictions on Jews and ordering the Jewish population of Lodz into the ghetto, and they packed them into a box, which they hid in the ghetto in the safest place they could think of - under a stinking toilet. Looking ahead, even in these circumstances, to a future after the war, he and his friend were desperate to have proof of what happened.

He went back, after the war, and found the box of posters. They hang on the wall of the museum, but after the talk, when the students went to look around the museum, I did not see the students looking at them. 


\section{At Treblinka there were branches of trees woven into the fence}

I noticed that some of the boys stopped and looked at a model of Treblinka. This model was the most frightening object I saw in any of the museums. It occupied a space about the size of two dining tables and was enclosed in glass. I can't say exactly why it was so frightening. My first thought was that I was imagining the dreams and waking life of a man who had all this inside him.

Later, when I thought more about the model itself, it seemed as though the particular green that he had painted all the watchtowers, the pile of little pink cloth corpses and the tiny leather whips which the guards held and trailed behind them, contained and emitted fear, as you would expect, and something else. Something inert. I found myself thinking about the word 'evil', an idea which I have always tried not to believe in. ${ }^{100}$ My sceptical friend reads a draft of this text as I am writing. What do you mean? she says when she reads this page. Do you believe in evil or not? I tell her that I believe it is best to act as though evil does not exist, even if it does. This is when she tells me that she finds New Zealanders dangerously naïve.

I notice that Thomas Keneally also finds himself trying to decide if what happened in places like Plaszów was 'evil'. He decides that the SS men who guarded the camp were not themselves evil but were persuaded by distorted language to go further and further away from what they knew was right until they ended up doing evil. I want to believe this, but I find the concentration on language distortions a bit too simple.

Perhaps I should focus on what is in front of me? The model of Treblinka evokes feelings. Whatever they are called, I should let them be inside me.

The man who made this model was a carpenter after the war. Faced with the problem of finding suitable materials to make Treblinka, he sometimes used dolls to represent people. Sometimes he used tiny soldiers. For the real branches of trees woven into the inner fence of the camp, he used the green plastic fringe that butchers use in their display windows to separate cuts of meat.

This model has entered the vortex of controversy surrounding every depiction of the Holocaust. Some say that if it is described as a model, it must be factually accurate in every respect. If it was wrong in some detail, they say, a chink would open into which doubt could be inserted. If the model is wrong, perhaps the museum cannot be trusted? If the museum cannot be trusted, perhaps the Holocaust cannot be trusted? It is safer to describe it as a 'conceptual model', a mind map, or an artwork.

\footnotetext{
${ }^{100}$ I note that Hephzibah, a Jewish woman in The Finkler Question, attempts to keep the word anti-Semitism out of her mind. It was, she believed, something you keep locked away. One day it forces itself into her vision in the form of bacon rashers wrapped around the door handles of her Museum of Anglo-Jewish Culture.
} 
The day before I saw the conceptual model of Treblinka, and in a different museum, I was reading small cards of text, thinking about the idea that curators in some museums have begun to identify themselves and describe their curatorial processes, in a bid to give visitors a more complete picture of how an exhibit comes to look the way it does.

This idea is of great interest to me. I saw no signs of it in any museums I visited. I heard about committees to advise curators and serious research into objects and their contexts. I also heard that an exhibition is the voice of the museum, not the voice of particular individuals.

The museum has removed some pieces from the conceptual model of Treblinka and changed others. In one place small pink plastic dolls have been replaced by plaster-of-Paris figures and a baby impaled on a pitchfork has been removed. The reason for this, according to Inga Clendinnen, is that the dolls and the spitted baby might make visiting schoolboys laugh. ${ }^{101}$ Soldier figures have been removed, because there were no soldiers at Treblinka. Miniature floodlights have been removed and the model has been enclosed in glass.

I had always imagined that a particular object would either be included in or omitted from a museum's exhibition. It interests me that curating reaches right inside this object to create the voice of the museum. But then I think of editors who might ask for a certain paragraph to be removed and I think that editors and curators take part in the act of bringing these expressions into the public gaze, this action paid for with the surrender of certain rights over the material.

${ }^{101}$ Clendinnen, Inga. "Building Treblinka." Agamemnon's Kiss: Selected Essays. Inga Clendinnen. Melbourne: The Text Publishing Company, 2006. Print. 169. 


\section{The difficulty of telling others}

I have been reading Jorge Semprún's Literature or Life. ${ }^{102}$ I see that following his release from Buchenwald, Semprún also suffered shock and surprise that humans had been treated like this by other humans.

If Semprún is to be believed, in the first few days after the camp was 'liberated', he and some of the other survivors at the camp were talking about how they would try to convey 'what happened' to people who had not been there. The group in Semprún's book was a sort of Who's Who of French and European literature and philosophy, lifted from the streets and salons of Paris and taken, via other camps, to Buchenwald. They met, while each person could, on Sunday afternoons, to celebrate all things French. Often they were physically unrecognisable to each other but recognised each other by quotations and ideas.

Their discussion that day in April 1945, which Semprún described in the 1990s, foreshadowed and summarised a thousand similar discussions about how to convey what really happened in the Holocaust and what the Holocaust really meant. I think of this discussion as a sort of set piece, like a Nativity Scene. In a Nativity Scene there is always a Jesus and a Mary and a baby and a crib. Here there are always certain arguments. Semprún sets them out for philosophical and artistic scrutiny.

Some of the survivors thought that conveying what happened to people who were not there could best be done by sticking to the facts. Some, like Semprún, thought it could best be done by the use of just enough art to make it possible for people to understand what was being described. Perhaps there will be a 'Literature of the camps' he suggests, rather disingenuously.

They are sure of one thing, these men in Buchenwald, that all the work of scholars, the compilation of documents and eye-witness accounts will miss the essential truth of their experience.

A professor turns to Semprún and smiles. The artifice of a work of art, he says, is their best hope.

Semprún's own view wins. Art, but not too much, will be needed to describe the camps. But after all this laying out of positions, another problem is raised. No matter how they are told, their stories will not be easily believable. This time no solution is found. There are questions too about those who will be listening to these stories of the camps. How hard will they try to understand what they are being told?

${ }^{102}$ Semprún, Jorge. Literature or Life. Trans. Linda Coverdale. New York: Penguin Books, 1997. Print. 
'You can't expect New Zealand people, who never even had to lock their doors at night, to understand such terrible things, but still they tried to understand. ${ }^{103}$ A woman called Herta Hochberg said this to Ann Beaglehole on 19 March 1987.

Herta had been in various camps, including Auschwitz and Bergen-Belsen, for four years before coming to New Zealand after the war. Her first job was as a machinist in a sewing factory. On the day of her birthday the girls gave her a big party with a cake and a budgie for a present.

They knew, these ordinary New Zealand girls, what I had been through. They didn't understand it of course. They thought 'She has been through a lot.' 104

The number of Holocaust survivors who were permitted to settle in New Zealand after the war is uncertain but Beaglehole uses a figure of 300 survivors between 1945 and 1948 as a possible generous estimate. ${ }^{105}$ Official policy remained the same as before the war. There were no set criteria for admission of refugees. Nor was preference given to close relatives of those refugees who had settled in New Zealand before the war.

Between 1948 and 1952 a total of 4500 displaced people came to New Zealand. These included some Jewish refugees, despite 'policy which still stressed that Jews and Slavs should be excluded. ${ }^{106}$

The refugees' attitude to the German language and to German culture was 'mixed'. ${ }^{107}$ On one hand pleasure in the German language had been killed by its association with orders and cruelty. George Steiner said later that after the Nazis, the German language 'made noise but created no sense of communion' ${ }^{108}$ On the other hand German was the language of much-loved books and poems. Some refugees tried to forget that German was their language. Some spoke it at home so that their children would be bilingual. Some didn't want their children to speak it. Some came back to it in old age.

Apparently one man threw out all his German books but read German newspapers. There is also a story about the Swiss Consul's dog, called by his English name 'Joe' in the street, but his German name 'Sett' at home. ${ }^{109}$

\footnotetext{
${ }^{103}$ Beaglehole. A Small Price to Pay 48.

104 Ibid.

105 Op. cit. 122.

${ }^{106}$ Op. cit. 6.

107 Op. cit. 57.

${ }^{108}$ Steiner, George. "The Hollow Miracle." Language and Silence: Essays 1958-1966. London: Faber and Faber. 1967. Print. 117.

${ }^{109}$ Beaglehole. A Small Price to Pay 58.
} 
Salomon Holzer, writing under the pen name Ben Akiba, published a novel in 1944 called Who Sow in Tears. ${ }^{110}$ This novel provides a rare glimpse from that time of what the refugees thought of us. The main character is Mr Rosen, a man from Czechoslovakia who owns a factory in Sydney where he manufactures woollen rugs. His wife and children were all left behind in Europe and the book is much concerned with Mr Rosen's loneliness and desire for a certain refugee woman whose neck is graceful like his wife's and whose eyebrows are dark like a Jewish boy scholar's.

Holzer lived in Wellington, not Sydney, at the time he wrote the book, and Steven Sedley believes 'Sydney' should be read as a substitution for Wellington. ${ }^{111}$ It is clear that Holzer wanted to keep some power over interpretations of his book. 'The characters in this book are the invention of the author who takes his ideas from human nature,' he says in the Front Matter of the book. 'Any similarity of names or places is entirely accidental and merely a coincidence. Any person attempting to bestow on himself any of the characteristics or personalities in this book will be considered as a trespasser.'

The story moves by personal narrative and anecdotes. In a few of these the author opens a shutter, shows a New Zealand scene, and closes it again, returning to the larger theme of $\mathrm{Mr}$ Rosen's torturous desire and his examination of Jewish wisdom for how it might assist him.

The shutter opens on a German general and an English general together in a room on the first floor of a building, comparing their fighting men. They each have one soldier. One after the other, each general orders his soldier to march across a room and out an open window twenty feet above a stone courtyard. The German soldier obeys and breaks his leg. The English general's soldier is 'a volunteer from one of the Dominions, New Zealand' ${ }^{112}$ This man stops at the window, apologises politely to the general, and refuses to march out the window, explaining that he would injure himself if he obeyed. As Holzer describes this situation, he pauses after the word New Zealand, and inserts this sentence:

The blue of the Tasman sparked in his eyes and the tan of the southern sun was still on his keen face. ${ }^{113}$

This seems to be an explanation of some sort for the soldier's approach. Then Holzer carries on with the rest of the story, the order and the polite mutiny.

\footnotetext{
${ }^{110}$ Akiba, Ben. Who Sow in Tears. Wellington: Eshape Publishing Co., 1944. Print.

${ }^{111}$ Sedley, Steven. "Reflecting on the World: Jewish Writers." Jewish Lives in New Zealand. Ed. Leonard Bell and Diana Morrow. Auckland: Random House New Zealand, 2012. Print. 119. (According to Sedley, Eshape Publishers, which Akiba says has its headquarters at P.O. Box 5036, Wellington C1, did not exist.)

112 Akiba 144.

113 Ibid.
} 
The shutter opens on a tram in Courtenay Place. In the tram Mr Rosen is rather reluctantly speaking German to a New Zealand Jew who wants to practise his German. A soldier home on leave hears them. When Mr Rosen and the soldier both get off the tram, the soldier challenges Mr Rosen.

'A foreigner eh? And how do you like our country? More than well? Happy here?'

'Yes, I am a foreigner,' Mr Rosen answers, 'I am from Czechoslovakia. I like this country and I would be happy here if the better part of myself did not remain in Europe.'

'What do you mean?' the soldier asks.

'I am sorry to say that my wife and four children are still there. Only I escaped. I left first as my life was in more direct danger.'

'Sorry,' the soldier says. He takes Mr Rosen's arm. 'Do come to the City Hotel and have a spot. We must become friends.'

Mr Rosen declines. 'Thank you very much,' he says, 'but I don't drink much.'

In another, rather stranger exploration of New Zealand, Mr Rosen ponders the link between circumcision, which was favoured by the Plunket system and therefore universally practised in New Zealand at that time, and the fact that 'the average New Zealander is just a little kindlier and more gentle than people I have met elsewhere. ${ }^{114}$

${ }^{114}$ Op. cit. 143. 


\section{The Holocaust Gallery at the Auckland War Memorial Museum}

I see from the floor plan that the Holocaust Gallery is small. It surprises me that it has no door. You walk into it, if you decide to do that, from a white balcony beneath a grand stained-glass window. Around the walls of the balcony the names of New Zealand soldiers who died in World War I are carved in into stone. Light falls on their names.

The inscription beside the names of these men reads:

They whom inscription upon these walls commemorate are those who at the call of King and country left all that was dear to them, endured hardness and finally passed out of the sight of men by the path of duty and self-sacrifice, giving their lives that others may live in freedom. Let those who come after see to it that their names not be forgotten.

The Holocaust Gallery has a plaque which reads:

Auckland War Memorial Museum gratefully acknowledges the support it has received in the preparation of this exhibit from the Auckland Jewish Community and the New Zealand Lottery Grants Board.

My friend from the museum industry says it matters what you see when you go into or come out of a museum. When he said this I thought immediately of a book. The front cover, the title, the bibliography - all the things that start shaping your expectations and responses before you even notice that it is happening. Sometimes you don't understand these references until after you have the book inside you.

My friend spoke of his visit to Yad Vashem, in Jerusalem. The land in Israel is harsh, he said and the light is harsh too, so when you step out of the museum you are in bright light and you are in a place which you know is almost unbelievably old. Judged by the language of signposts and the names on buses, you are in a Jewish world, but you know that everyone has been here and you know that this is the most fought over city in the world.

Compare that with coming out of the Holocaust Museum in Washington D.C. he said. The Holocaust Museum is located in American Museum headquarters. Within a short distance are the World War II Memorial, the Korean War Veterans Museum, the Vietnam Veterans Memorial, the Museum of the American Indian, the Air and Space Museum, the German American Friendship Garden and many more.

You soon get the idea, he said. The Holocaust of the Jews is a significant event for America, but only one of many. 
Thinking about the expectations set up by the Holocaust Gallery in its context in the Auckland War Memorial Museum, I would have to conclude that the Holocaust was an aspect of war, that it was small and contained and much less significant in New Zealand than World War I or II and that its depiction in this place relies on the Jewish community and charity.

The Holocaust Gallery really is a small room. It is dark in there and opera music plays softly in the background. This music is not grand, or beautiful or comforting. It affects me in the same way as a single high note from a violin played over and over. The day of my visit, one middle-aged man, one young Asian woman and her two small children were in there. When I walked in, the man left. I paced out the room and found that it is approximately 8 metres long and 3.5 metres wide.

On the walls there are glass cases containing photographs and small pieces of text. There are two telephones mounted on the wall and two wooden stools. At the time of my visit one of the children, aged perhaps three or four, had one of the telephones up to his ear. At first he just stood there then something he heard made him laugh and he handed the telephone to his mother. She hung up.

I looked more closely at these telephones and found that there was a menu of thirty two stories which you could hear if you pressed a numbered button, a bit like a jukebox except that only you would hear the story. Later I was very struck by the fact that these telephones only worked in one direction.

'Press a button to listen to a personal story' says a notice. If the sun is shining outside, and it often is in Auckland, you might begin in a hopeful way with \#27, Hidden by Righteous Gentiles - the one about a man who said to his Jewish friend 'Come to me if you are ever in trouble' and meant it - you hear his name - he is dead now - and no, he didn't do it for the money, although a certain amount of money did change hands.

You might sit on one of two round wooden stools attached to the wall an awkward distance from the telephones, and you might listen to \#27 which had a happy ending, and after that you might try one about someone hiding under the stairs when the Gestapo came, and you might think that this person must have survived to tell this story, but that is only two stories and there are thirty-two. 
So - sooner or later you always end up with \#31, The Guards at Auschwitz which, in the shadows of this small room, I misread as The Sparks at Auschwitz, no doubt due in part at least to Fire, Fireflies, Fire roses, Kristall, a burning night, stars, the chamber of smoke, smoke without a shape, signals and signs of the poet Rose Ausländer, whose work I was reading just before my visit to the museum. This week, as I write about the Holocaust Gallery, I am also reading Jorge Semprún's description of his first few months after being released from Buchenwald. At night, in Paris, lying beside a beautiful young woman to whom he has made love, he is woken by a memory of the guards shouting over the loudspeaker. Crematorium ausmachen, they scream. Crematorium shut down! They say this because flames rising from the chimney might attract Allied night bombers.

My friend who works in the museum industry said that not all visitors to museums are seeking the same thing. He himself is seeking a moment of connection. A 'transformational moment', he called it. I had two moments of connection in the Holocaust Gallery of the Auckland War Memorial Museum. The first was when I saw the story of a small wooden urn, which sat on a shelf in one of the glass cases. I was grateful for the inscription beside the urn. By itself the urn would have said 'ashes' to me but nothing more.

The story on the card says that Karel Beran, an Auschwitz survivor, went back to the camp on 16 September 1946 and, witnessed by 'a senior government official', one Dr Armin Glanz, took ashes from the crematorium. These ashes came to New Zealand with Mr Beran. For some years he kept the ashes from Auschwitz in this wooden urn. I picture it on the top shelf of his wardrobe, next to his hats. The ashes are buried now, the card says.

One evening Semprún and his girlfriend enter an apartment where all the furniture is covered by white sheets. The young Semprún, living through his first summer as a survivor, is overwhelmed by unease brought on by the white sheets in the Paris apartment, and at first he does not know why. His unease grows and grows and he feels he will die, or that he must die in order to avoid this trail of feelings that lead to his own death, the only thing that he really owns.

Semprún leaves the beautiful woman's bed, walks the streets of Paris until dawn when he knocks on the door of a woman he knows who is a writer. She will neither make him talk nor stop him talking. This makes her a refuge.

I connect Karel Beran and Jorge Semprún, both trying to be alive after their release. I wonder if Karel Beran had someone he could visit at dawn or whenever he felt most oppressed. I try to imagine a former prisoner making the decision to return to Auschwitz. I try to imagine this man making his feet take him onto a train going to Auschwitz. 
I imagine a mixture of chaos and red tape and officials who might have been part of the Nazi administration.

I wonder why he went this day. Is it coincidence that the first Nuremberg trials were just about to end, or that in 1946, 16 September fell during the month of preparations for the High Holy Days? I wonder if the purpose of the trip was to bring ashes away or whether that act was something he felt moved to do on the spot, when he was there?

I imagine this man finding a tool or making his hands into a tool to scrape ashes from an oven into some container. I do not have him beside me to tell me how he was able to do this. But even from my sunny room on this windy spring day, more than sixty years later, I know this was an important act.

The second moment of transformation for me in the Holocaust Gallery was seeing a letter, written in 1938, by a man who worked for the Department of Customs.

Late in that year, when he was probably already thinking of the pleasure of cricket down at the Basin over Christmas, or of talking the afternoon away over a couple of flagons, he wrote, on behalf of the Minister of Customs, to a man on the other side of the world. No, he said. The government of New Zealand had declined the application for a permit to enter New Zealand. He added the following paragraph to his letter.

It is considered therefore that it would be hardly worth your while making further application for a permit to enter New Zealand, it has recently been found necessary to discontinue the issuing of such permits except in very special circumstances. ${ }^{115}$

I have written letters for other, more senior, people too. I am familiar with the general muddiness and confusion of things people say and do and the tiny pleasure to be found in a set of circumstances fitting any criterion at all. I also admit to a pleasant sense of order and a slightly aggressive satisfaction from constructing a well-written ' $\mathrm{No}^{\prime}$.

But what would the definition of 'very special circumstances' have been in December 1938 ? As I have said before, there was no quota to fill, and there were no set criteria for processing applications for entry to New Zealand at this time. Each application was considered individually.

\footnotetext{
115 Beaglehole, Ann. "The Response of the New Zealand Government to Jewish Refugees and Holocaust Survivors, 1933-1947." Holocaustcentre.org.nz. n.p., n.d. Web. 12 Oct. 2012.
} 
Clearly the decision had nothing to do with fear, or hunger, or cold, or lack of legal rights, or children, or trains, or dogs or guns, or isolation or desperation. In fact, referring to any of these probably counted against someone. Three ingredients of success come up often in discussions of applications from European Jews for permits to enter New Zealand before the War.

Contacts

Money

and Luck. ${ }^{116}$

In my mind this man who worked at the Department of Customs was entirely satisfied with his letter, which seemed to slam the door to New Zealand to a Jewish family from Europe, in 1938. I had mentally convicted him of anti-Semitism, even if I never said that word. But when I told this story to someone else who also works for the government, she said she wondered if later he looked back on his letter and felt guilty. Her question seemed to open the door to viewing this man with more compassion.

I would have liked to read some files of correspondence between the Customs Department and applicants for entry to New Zealand, to see exactly which circumstances matched which response, but a fire in 1952 destroyed Customs files from this period.

When I came home and thought about this small dark room in the Auckland War Memorial Museum, I thought I would like to write about the experience of visiting this room in a poem. The poem would be in the shape of a brick, like the room. I sat down at the table and tried to make a poem in the shape of a brick. But my poem would not make a brick. Instead it made an awkward thing - lumps, linked by joints, like the carriages of a train. My poem focused on the rigid stools and the one-way telephones. It was burdened by too many connections. I threw it away.

I have already mentioned the occasion when I thought some words said 'the sparks at Auschwitz' when they really said 'the guards at Auschwitz' and my theory that this could be explained by the fact that in July and August 2011 I tried to translate some poems by Rose Ausländer.

There were perhaps fifteen of us who worked on making English translations of some of her poems.

${ }^{116}$ Beaglehole. A Small Price to Pay 14. 
As each person spoke I could hear the same four elements in different proportions: love for the German language, a feeling for poetry, interest in the Holocaust and a connection with Europe. One man, who may have had all the other elements too, said nostalgia for the Austro-Hungarian Empire drew him to Ausländer and the poets of Czernowitz.

I found myself first allowing and then encouraging a sort of parallel chattering as I read Ausländer's algebraic poems until, by the end, every novel I ever read about what happened to Jewish people during the war was present and every personal account I had ever heard of how they felt and how they tried to live afterwards was speaking in my mind. This was what I brought to the table to meet her poems.

I heard a recording of Ausländer reading some of her poems. She had an unusually deep voice for a woman. This voice of unassailable authority, the tight rhythms of her German and her sparks made me feel like a schoolgirl.

Lodz is a place in Poland, which is supposed to be pronounced something like Lodge or Wooj. Once, when I was speaking to a staff member about my reasons for visiting a museum which concerns the Holocaust, I said the word 'loss'. The museum staff member thought I said 'Lodz'. When he is at work, and perhaps even more at home, he brings a list of ghettos and camps to the table.

It is the Jewish custom to place a stone on a grave to help the dead to dissolve into dust and to show them that in that moment, someone remembers them, whether as air or sparks or dust. Every year, at the United Nations Holocaust Remembrance Day ceremony at the Makara cemetery, the survivors place a stone to show they were there. The wind blows. The pine trees bend. After that, anyone who wishes may place a stone.

In the voice of Paul Celan reading "Todesfuge", I hear a man led by his poem. I hear his poems deeply, with my mouth. I hear him travelling East at night, alone. I hear him laying stone on stone. Each night he finds a dark shining heart and holds it in his hand. From this heart flows cunning. I hear the voice of the heart in a dream. It comes from my own mouth. I hear him laying stone on stone. Every exiled poet is a stone. Every place or person with more than one name is a stone. Every date is a stone. Every mother is a stone. Every blue eye is a stone. Every brown suit is a stone. Every photograph is a stone. Person-stone, bookstone, place-stone. 


\section{Endings}

I have always believed that writers write one long continuous book which they publish in sections. The end of one becomes the start of the next. A topic steps forward into the limelight for a while and then steps away and into the background.

Hirsch and Spitzer finish their investigation of the afterlife of Czernowitz by describing the sale of tiles from a stove that used to be the heart of a woman's home. I consider finishing this investigation with a description of inanimate waste left on the footpath in Melbourne. But, for reasons that I do not fully understand, I decide to finish with land and trees, philanthropy and commercial sponsorship.

The land I live on and all the flat land and hills nearby used to be covered in bush. Kohekohe trees in this bush were so big that waka could be made out of them. Last weekend, at Whareroa Farm, I saw this record of the Lower Ti Kouka Stream Planting in 2011. The event was funded by WWF-New Zealand ${ }^{117}$ and the Tindall Foundation. ${ }^{118}$

Shelter and Fence
Kānuka
Mānuka
Koromiko
Ti Kouka
Ngaio
Kōwhai
Harakeke
Taupata

\footnotetext{
${ }^{117}$ With sponsorship from Toyota New Zealand Ltd, Spicers Paper, Buddle Findlay - New Zealand Lawyers, Totally Wired and Café L'Affare. wwf.org.nz. n.p., n.d.,Web. 1 May 2012.

118 'The Tindall Foundation is a philanthropic family trust established in 1994 by Stephen and Margaret Tindall. Between 1995 and 2011, The Tindall Foundation has donated $\$ 10$ million to community organisations and initiatives across New Zealand. In addition, it has paid over $\$ 90$ million to the Government in prepaid tax.' tindall.org.nz. n.p., n.d. Web. 1 May 2012.
} 
Streamside - random scatter as close to gorse as possible -

Karamū

Ti Kouka

Kōhūhū

Mānatu

Puahou

Putaputawētā

Kōwhai

Ngaio

Bush edge -

Karamū

Kōhūhū

Puahau

Putaputawētā

Koromiko

Beside the groups of Toetoe -

Ti Kouka

Kōwhai

5 single Ngaio

Kānuka

Swamp carex

Cyparus

Harakeke 


\section{And this}

This morning I met people for whom Karel Beran was a family friend, not a person in a story. I found out:

1. That Mr Beran was interviewed by the Survivors of the Shoah Visual History Foundation and that this interview is five hours long.

2. The Alexander Turnbull Library has a copy of this interview.

I have every intention of listening to this interview. I hope to find out more about $\mathrm{Mr}$ Beran's reasons for the trip back to Auschwitz in 1946 and for bringing away ashes from that place. This meeting made me realise that the 'tree ending' for the chapter, while melodious, and a serious opportunity to learn about the missing plants of the Kāpiti Coast, promises a future and a resolution which is true enough in one way but too hasty and not quite honest. 


\section{A particular kind of conversation}

I found the 318-minute video recording of Karel Beran being interviewed by Jason Walker in the audio-visual collection of the Victoria University Library during a search of the catalogue using the key words 'Holocaust' and 'New Zealand'. The catalogue entry looks like this:

[Testimonies] [videorecording] Survivors of the Shoah Visual History Foundation, pub. Shoah Foundation, 2005, L.A. Calif.

After that there is a long list of names, which have a number beside them, and no other explanation. If I had not visited the Wellington Holocaust Research and Education Centre and been given the name of a woman who had interviewed many Holocaust survivors in Auckland, and if she had not replied warmly to my email about Karel Beran and the story of the urn and told me that he had made an interview for The Survivors of the Shoah Visual History Foundation, I would never have realised what the catalogue entry meant - that if I searched through the fifty or sixty names, I would find Karel Beran's name.

The two DVDs of Karel Beran's interviews and all the other Shoah Foundation interviews from New Zealand are held in the Closed Reserve section of the Library. No special permissions are required to watch these interviews. On my visit to the Library to start watching the interviews I saw this inscription on the wall of a cubicle in the ladies' toilets:

The holocaust is the shittiest thing to discuss.

I assumed from this that another student, with different interests from mine, had been required to find out more about the Holocaust than she wanted to. When I told a friend about this statement, she said she pictured a young woman in a tutorial, finding herself unable to think of anything she could safely say.

I found Karel Beran's interview, which I regard as a treasure, in the National Library of New Zealand as well as in the Victoria University Library. The interview is one of hundreds made by the Survivors of the Shoah Visual History Foundation, based in Los Angeles.

The purpose of the Shoah Foundation is:

To overcome prejudice, intolerance and bigotry - and the suffering they cause through the educational use of the Foundation's visual history testimonies. ${ }^{119}$

\footnotetext{
${ }^{119}$ Notes accompanying Karel Beran's 1997 interview. (In 2006 The Survivors of the Shoah Visual History Foundation became part of the Dana and David Dornsife College of Letters, Arts and Sciences at the University of Southern California, and changed its name to become the University of Southern California Shoah Foundation Institute for Visual History and Education.) dornsife.usc.edu. n.p., n.d. Web. 22 Oct. 2012.
} 
The interview took place in Auckland on 10 December 1997. Watching 318 minutes of Karel Beran talking and Jason Walker asking questions, I noticed that this was by no means an ordinary conversation. Walker asked short questions and offered nothing in return. He never interrupted Mr Beran, but neither did he ever help him. If Mr Beran stopped and was clearly upset, Walker was silent and after a minute Mr Beran would continue. Once Walker asked Mr Beran what his Auschwitz number was. Mr Beran said he had forgotten and rolled up his sleeve to look but he couldn't see the number without his glasses. Mr Beran asked Walker to read it, but he didn't. I wondered if reading these numbers out loud and hearing them in his own voice would in some way make Walker feel as though he was one of the men who made the numbers.

I took from the overall style of the interview that there was a strict purpose to this conversation - to elicit and place on the record all Karel Beran could give of his personal experiences in the Holocaust - and that there would be no deviation from this purpose at any time.

During the interview Mr Beran often looks down and to the right in the space between a question and his answer. He says that there was always anti-Semitism in Austria where he lived as a young man, although it grew after Hitler took power. He speaks about two friends from the camps who stayed behind in Europe when he came to New Zealand. One, a social democrat activist, was imprisoned again after the war by the Soviet-led government of East Germany. Mr Beran shows photographs of this man's release years later. The other friend, Dr Glanz, he lost touch with during the long period after the war and before the collapse of the Soviet Union, when it was dangerous for people in Czechoslovakia to correspond with people in the West.

I learned that there was no impromptu decision to take ashes from Auschwitz. Karel Beran went back to Auschwitz with his friend Dr Armin Glanz in September 1946, to bring away some ashes to be interred in the Czech monument to the Unknown Soldier. Dr Glanz, whose name is on the caption in the Holocaust Gallery at the Auckland War Memorial Museum, was not, as I had imagined, an official of the Polish government of the time, with a possible Nazi past, but an official in the Czechoslovak government. Mr Beran and Dr Glanz had been together in Budy, a sub-camp of Auschwitz. 
Mr Beran and Dr Glanz needed a special permit from the Russians and the Allied forces to enter Poland and it may have taken some time for this to be granted, but 'finally' ${ }^{120}$ the men received a permit to enter Poland for one day. Perhaps this implied delay is the only reason for making the trip in September 1946.

The two men travelled, not in a train, which I had imagined as a mirror image of their deportation, but in a little Skoda sports car, which some friends with a farm had successfully hidden from both the Germans and the Russians, under straw and hay. There were, Mr Beran said, many happy times in this car, including his wedding trip with his wife.

Mr Beran said that the car was still at the farm. The son of the original owner had told Mr Beran that he would keep the car as long as he lived, as a memorial to Mr Beran. This was one of the most emotional moments in the interview. That Skoda sports car would be, as $\mathrm{Mr}$ Beran said a few seconds later in his practical voice, 'a very nice vintage car by now'. ${ }^{121}$ At the end of the interview Mr Beran showed some photographs, one of which was of this car. I have the impression, from listening to Mr Beran's interview, that this little car is one of the most important objects in his life.

I do not know what has happened to this very nice vintage car full of happy and sad memories since 1997.

On the day of the interview in 1997, Mr Beran was not sure whether he and his friend went to Auschwitz on 10 or 16 September. Sometimes he has said one date and sometimes another, he says. The date could be checked by looking at his passport, he points out. I notice his concern that what he says should be accurate.

What follows is the story Mr Beran tells of his return to Auschwitz, as he tells it to Jason Walker on 10 December $1997 .{ }^{122}$ Only comments pointing out topics of great emotion and a few joining words are mine.

Mr Beran and Dr Glanz crossed the border without much trouble and drove straight through the plains to Auschwitz. In the main camp there were some maintenance people who had no objections to letting people have a look through. Already some documents had been gathered together like a camp museum. Apart from the memories that both of them were trying to cope with, there were no particular difficulties. The men went on to Budy, where the local population had moved back into their houses. These houses had been occupied by the Waffen SS during the war. At the Commander's house, which Mr Beran and Dr Glanz knew well, they saw a stork's nest on top of the chimney.

\footnotetext{
${ }^{120}$ Karel, B. 1997, “Interview by Survivors of the Shoah Visual History Foundation," Auckland, New Zealand, 10 December, Videotape 6.

${ }^{121}$ Op. cit. Videotape 6.

122 Op. cit. Videotape 8.
} 
They remembered that for two or three years the stork family used to come back each summer, but now, in autumn 1946, the big nest was empty.

Most of the watchtowers and fences had been removed.

The two men spoke to the people there as best they could in Polish and Czech. The people were ordinary poor farmers who had been removed from the land by the Germans and were now back. They didn't know much about what was going on at Auschwitz, they said, which Mr Beran and Dr Glanz didn't want to believe. It was possible, Mr Beran added, if they were busy living with very little time for anything else.

The buildings were still there, including a blacksmith's shop which Mr Beran had helped to build. At Birkenau the crematoria were partly demolished. There they gathered the ashes they had set out to collect.

The day ended with a lot of sad memories, back at a town on the Czech-Polish border. The men sat at their hotel, watching flames coming out of the huge chimneys of a local steelworks. At this point in the interview Mr Beran is weeping. Just like the crematorium, he says. Neither of the men could sleep, so they packed up at midnight and drove home.

That was it, Mr Beran says, trying to end this story.

Mr Beran kept a small part of the ashes and nobody knew about it. The rest went to Prague and were at some stage interred at the Tomb of the Unknown Warrior.

That ended the journey. (He tries again.)

The ashes I kept for fifty years here, he says, thinking some part may be my parents. As I grew older I thought they should be put to peace. With the help of the Jewish Community and Sol and Ruth Filler and the very active support of Rabbi Lawrence, the ashes were laid in a little sealed container at the foot of the Holocaust Memorial with a small stone notice telling the story that happened, on the $23^{\text {rd }}$ of November 1997. Last month.

That's the end of the story. This is his last try. He succeeds. There are tears on his cheeks. The interviewer says 'Thank you.' 
Earlier, in tape 7, the interviewer had invited Mr Beran to give a message for the future. This is his message.

The general message is like it was. There shouldn't be a war. The special message is that any racial discrimination should be avoided at all costs. I was always for this.

After all this reading and all of Karel Beran's words and all the messages from the men and women at the museums, this is my own position. I found out that New Zealand received survivors of the Holocaust as almost every country did and that those people were one step away from me all my life. I found out that New Zealand has a record of callousness towards the refugees from Hitler and that the first Labour government, which I had always thought to be admirable and humane, brought no great goodwill to this issue. I now agree with those who say that anti-Semitism remains at a low level in New Zealand because the Jewish population is small and relatively quiet. I also found out that the reasons I put forward earlier for not knowing about Holocaust survivors' lives in New Zealand identify me as someone who grew up out of touch with the Jewish community.

On the subject of trains, storks, chimneys, flames and ashes, I wonder if all I have done is repeat a list of conventions. I wonder if I could have done anything else but repeat those conventions and whether I could have displayed them more clearly in a simple list.

Significance. Entitlement. Exploitation. Voyeurism. Size.

All the much discussed problems remain. I wonder now if I should hide the traces of my investigation as I hid my poem and my play. I wonder if, having opened this door and met all these people, I have an obligation to continue this search for all of my life. What would it mean if I did and if I did not?

Today is 27 May 2012 but this is not the end. One day soon I will meet Mr Beran's family. His children will be roughly my age. I already know that they speak with an accent like mine, but I imagine their childhood will not have been exactly like mine. They and their children have a life in which researchers can come any day, knocking at their door, asking questions about a man who was their father, not a man in a book. They may feel that they, like the volunteers in the museums, are guardians of a story whether they like it or not, and that sometimes this is a full-time job. I would like to hear more about Karel Beran's life in New Zealand, but perhaps that is their business. 


\section{Part Four: An Index}

A

absence see missing people

activities of the author

as a child 130,131

dreaming 217

grid search of the neighbourhood 169

identifies as Tralfamadorian 197

making a list of worn out books 36

making poems 49-53, 57-61

mistakes made by 147,249

sleuthing 120-121, 165-167

witnessing 208, 237-239

see also Jenner, Lynn

activities of the subconscious 60

Activity Theory passim

methodology 75

aesthetic of loss 50

Akiba, Ben (Salomon Holzer) 243-244

albatross 171

Alexander Turnbull Library 210, 253

amaranth 87

America, safe 148

American professor 143-144

And also it was cold there in the winters

(play) (Jenner) 232-233, 235

And Europe Will Be Stunned (film)

(Bartana) 67

Anna Karenina (book) (Tolstoy) 108-109

Anschluss 34

anti-Semitism 202, 219

in Austria 255

in New Zealand 203-205, 228-231, 249, 258

anxiety of influence 60

apple blossom petals 47

apple trees 130

archaeology 76-77, 83, 95

analysis, as a form of 37

division of labour 81

heavy responsibility of 38

archivist, self-appointed 189

artifacts

discarded 67

see also objects

ashes see Beran, Karel; Celan, Paul
Ashmolean Museum (Oxford University) 77

Ashton, George 36

assimilation of Jews in New Zealand 202

At the Edge of Memory: A Family Story (book) (King) 215-218, 228-233, 235236

Auckland War Memorial Museum, Holocaust Gallery 245-249, 255

Auschwitz Birkenau (concentration camps), Beran's return to $247-248,253-$ 258

Ausländer, Rose (Holocaust survivor) 249250

signals and signs 247

suitcases 221

Austerlitz (book) (Sebald) 184-185, 198

Austerlitz, Jacques (child refugee) 184, $198,221,234$

Australia 153

anti-Semitism 209

contemporary immigration policy 207

Erna Winton 230-233

Holocaust survivors 207-209, 212, 226, 237-238

Mendelsohn visits 226

museums of the Holocaust 183-184, 187, 192-193, 209, 237-240

refugee's suitcase 221

sunshine 193

writers 189, 222, 234

"The autobiographical museum" (Jenner) 31-104

awkward patches 173

awkwardness 54, 74, 199

B

baby 240

backpacks see suitcases

backshadowing 220

bank notes, shredded 96

bank statements 36

bank vault 156

Bartana, Yael 67-68

Beaglehole, Ann 204, 209, 242 
the Beatles 187

behaviour

apparently irrational 71

of books 139

careless 121

behaviour

eccentric 165-166

evasive 161

gutless 183

naturally occurring 75

observation of everyday 75

polite and reasonable 71

possibly unethical 121

Belgrave, Maurice (Moshe Belgoraj) 215-

216, 218, 221, 228, 233

Belgray, David, quest 229-230

bellbirds 207

Ben Canaan, Ari (soldier/farmer) 187

Benjamin, Walter 40

Beran, Karel (Holocaust survivor)

ashes put to peace 257

in a boxcar 196

brought urn of ashes to NZ 210, 247-

248, 255-257

message for the future 258

oral history interview 253-258

return to Auschwitz 247-248, 253-257

Bichuch (Eastern Galicia) 195, 226

overlooked by an empty castle 150

birding 141

birds, surmises of 32

black birds 33

Bloomfield from Carlton (Holocaust

survivor) 222, 234, 237

see also dybbuks

blowing up a photograph 185

blue in the mind's eye 206

blue light, pool of 169

Blue Moon of Kentucky (Monroe) 70

blue poison 181

blue sea 171, 200, 206

blue shirts 67,187

blue sparked in his eyes 243

Blue Suede Shoes (Perkins) 70

Bolechow (or Bolekhiv) (Ukraine) see

Bichuch books

about how to disappear 111, 164

about how to find people 164

about the Holocaust 210

behaviour and functions 139

cut into 52

folding down the top corners of their pages 109

free 108

opened at the back 202

Quilter's secondhand bookshop 124, 203

Russian 108-109

second-hand 109, 110

serve as a quarry 33

three prices 124

wear out 33, 36, 187

in Yiddish 221

borscht, recipe for 119, 148

Brett, Thomas 64, 66

briefcases and handbags see suitcases

bringing in the cows 149

Buchenwald (concentration camp) 241

budgie 242

see also New Zealanders, naïve

butter 135, 200

C

"Cairn" (Jenner) 177-258

reaction of readers 190

campfires, flickering 182

cannibalism 182

canoes 170, 171, 181-182

Canterbury Earthquake Recovery

Authority 133

Canterbury Museum

Māori fish hooks, woven bags and cloaks, stuffed birds 132

ship's cabin, shop full of tiny children's boots, gallery of period dresses 129

taonga borrowed from 132

capitalism 91, 116

carelessness 121

Carkeek, Wakahuia 179, 181-182

carrying home the body of someone important 78 
Carson, Anne 43, 50

categorising silences 144

Celan, Paul (Holocaust survivor) 183,187, 198, 213, 219

Todesfuge 183, 250

Christchurch

1922135

Christchurch

1962-64 129-132

2010, 4 September, first earthquake

107-108

2011, 22 February, third major earthquake 114

2011, April, looting and rumours 155

2011, May, vagrant living in the Grand

Chancellor Hotel 163

2011, late December, empty Red Zone 127

access to Port Hills 138-139

Addington 114, 130

Anglican Cathedral, six memories of 127-128

Ballantynes Department Store 127, 135

Bridge of Remembrance 127, 131

Cokers Hotel 131

Colombo Street 127

constant rattling and rolling 125

Delano's Magic Shop 131

doing business in 161, 174

everyone was terrified and a few people had left 124

Fails Cafe' 131

Heathcote River 133-134

NZ Sign Language sign for 122

Press Lane 131

rebuild 174

Shirley Lodge 135

The Swiss Chalet 131

unsafe 114, 124

what has been lost 123

Whitcombe and Tombs 131

Wood Brothers flour mill 114

see also Canterbury Museum; earthquakes

classes, belonging to two 173

Clendinnen, Inga 240
Cole, Teju 190

Cologne University, archives of 46

communism

reported to be dead 112

in Russia 116-117

The Communist Manifesto (book) (Marx

and Engels) 109, 112

compassion, price of 143

complexity 92, 112

conservation 87-89, 93

Courtenay Place (Wellington) 244

Cowan, James

helped by Hone Taare Tikao 137-141

liminal experience 141

Maori Folk Tales of the Port Hills see Maori Folk Tales of the Port Hills

mountain pas of the fairies 140

used to take notes in shorthand in

Māori 140

cows 149

crocodiles

mummified 95

The Street of Crocodiles 32, 52

cuckoos

long-tailed 181

shining 181

cultural tourism 231

curatorial processes $68,239-240$

Czernowitz 185, 219, 250

afterlife 251

D

'Daedelus' (musician) 63, 64, 66

Daniel, Robert 46

Davenport, Guy 99

Davin, Dan 201-202

death song 182

deliberate ignoring 50, 132

demolition 114, 132, 162, 163

the Depression 203

men on relief 129

diamonds 146

sewn into hem of coat 167, 196

see also rings

disappearance

DIY 172 


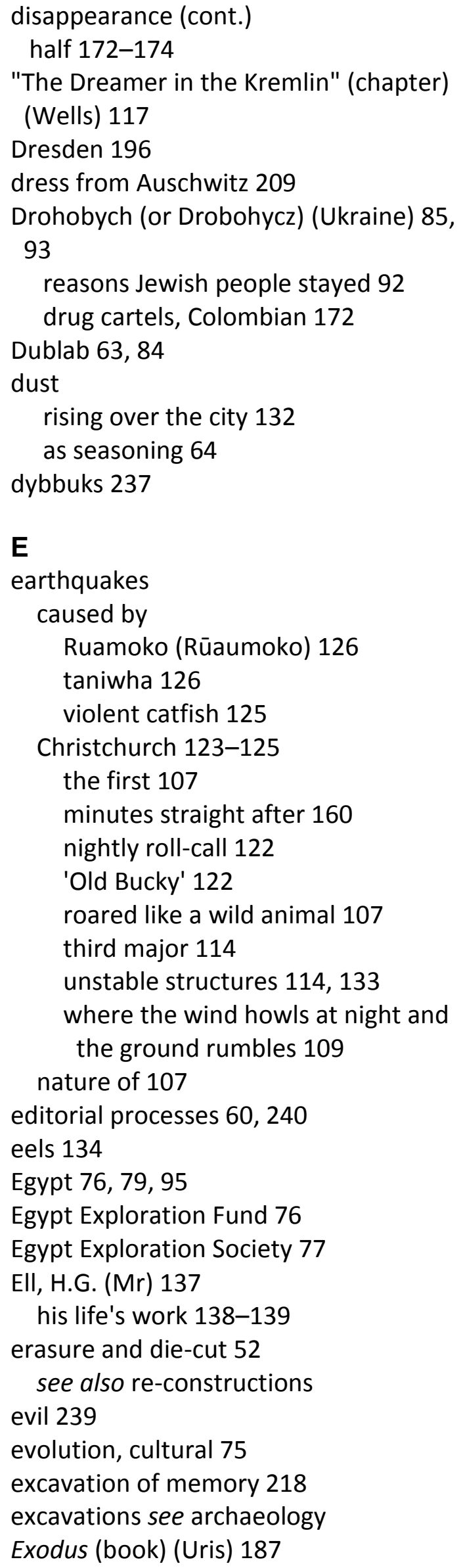

extremist ideas 214

$\mathbf{F}$

failure, awareness of 143

farms

inherited 156

lost 156

Farouq (Moroccan political philosopher) 190

fate, catches up with them 170

feelings

'filial piety' 37,41

guilt 41, 190, 210, 249

with no name 122

something missing 173

strange 122

unease 247

figurines

woman baking bread 35

woman grinding grain 35

Finding Pictures (documentary) (B

Geissler) 85, 88, 91, 92

fires 180, 247, 249

flagons 130, 248

flames

from crematorium chimney 247

flaming like a bushfire 57

flaming wooden wheel 185

in Holocaust writing 258

inflame violence 189

open 48

single 147

from steelworks chimney 257

words which survived 59

fog of awkwardness 54

food gathering 182

foreigners 35

forgetting 131

fortune, making and losing 100

Freud, Sigmund

on the Acropolis 41

collection of objects from antiquity 37

essay "A Word about Anti-Semitism" 39

fate of sisters 39

father 41, 150

international supporters 39

leaves Vienna 37, 39 
From Dust to Light (album) (Tikao) 132

From Europe to New Zealand (book)

(Lochore) 228-229, 235

From Ur to Rome (book) (Gadd) 33

G

Gadd, K. M. (Kathleen) 33, 34

Geissler, Benjamin (documentary film

maker)

Finding Pictures see Finding Pictures

The Picture Chamber of Bruno Schulz 94

Geissler, Christian (director's father) 86

gentle subsidence 173

German language and culture 242, 244, 250

Glanz, Armin (Dr) (Holocaust survivor)

247, 255, 257

Goethe, J. W. von, in extreme old age 40 gold

cups 47

golden afternoon 140

golden age 84

golden autumn 222

jewellery 209

lichen 173

mining 54, 121

ornament 83

sandaled girls 47

sovereigns 141

star 210

value of 156

Green, T. E. (Mr) (Tame Kirini) 137, 138

Grenfell, Bernard 45, 76, 77-78, 82

grief, age of 143

Gronewald, Michael 46

Grywacz, Nahum (archivist), his last words 152

guides 181-182, 195, 196, 208-209, 212

H

hair

dein aschenes Haar 183

blanket made partly of 183

hāpuku 178, 182

Harry Lime theme (song) 165

healing the wounds of strangers 179

Heberley, James 'Worser' 178 hibakusha (survivors of the atomic bombs)

211

high blood pressure, brought within normal limits 143

Highland flower 156

Hiroshima Peace Memorial Museum

(Japan) 211

Hirsch, Marianne 185-186, 251

hissing noise 193

history, weight of 178

history-making 150-151

see also Ringelblum Archive

"History-making" (Jenner) 105-176

Hochberg, Herta (Holocaust survivor) 242

Holocaust

controversy surrounding artistic

depiction 239

opening up the subject 187

parallel chattering 250

problems of writing about 189, 241, 258

wealth 195

Holocaust Centre of New Zealand 209-

210, 221, 254

Holocaust Museum (Washington D.C.) 245

Holzer, Salomon (pename Ben Akiba) 243244

honeysuckle 157

horses

one 149

packhorses 61

unnaturally tall 127

hot black earth 47

Houdini, Harry, folded in three 148

housie 135

human activity, structure of 94

hunger 117, 192

marchers 201

sickness caused by 121

sweetness lingered 147

Hunt, Arthur 45, 76, 77-78, 82

Huntley \& Palmers biscuit tins 76, 78

bibles packed into 80

scabbards cut from 79

tank made out of 78

hyacinths 108 


\section{I}

If Not, Winter (book) (Carson) 50

I'm not sure what to call what I have done (Jenner) 59

images $74,127-128$

flicker 51

imaginary flower 87

index, two-page 181

indifference, flavour of Pākehā New

Zealand 132

insurance 114, 223

in advance of a likely catastrophe 71

claims 155, 162, 166-167

valuation 156-157, 159, 165

see also value

insurance company

keeping Ted waiting 167

trouble with 155

intellectual property 112

intentions

archaeological 36

of the author 189, 253

to commit a crime 161

intertextuality 65, 69

investigation, reflexive 186

investments, diversified 143

Israel 92-93

J

'J. Rocc' (musician) 63, 64, 66

Jaeger, Abraham (grandfather of

Mendlesohn) 195

Jarecka, Gustawa 152

Jenner, Lynn (author) 127-128

play, And also it was cold there in the

winters 232-233, 235

poems 47, 147, 249

I'm not sure what to call what I have done 59

Keas call for me 58

The muttering poem 51, 52

Now again, grasses wave 57,60

The poem about the candle 49, 50

Re-Collections

"The autobiographical museum" 31104

"Cairn" 177-258
"History-making" 105-176

relatives 129-131, 135-136, 200-201, 210, 215

research 195, 207-210, 237-240, 245249

endings 251, 253, 258

methodology 75

see also Activity Theory

people's reactions to $121,188-190$, 207, 239

rules 234

see also activities of the author

Jewish Historical Institute of Poland 154

Jewish Museum Berlin 199

Jewish New Zealanders 201-204

Jews

commemorating death 48, 250

invisibility in New Zealand 203-204

Polish/Jewish relationships 92, 150, 151

returning to Poland 67

social skills 117,188

jobs

barman 173

building a hiding place 238

chauffeur 135

copy writing 173-174

PR 174

in the prison, mental hospital and railway workshops 130

sewing machinist 242

truckdriving 172

Judt, Tony 191

K

Kafka, Franz 215-216

Kaluzhni, Nikolai and Nadezhda 85

Kāpiti Island 179-182, 180, 197, 200

Katzenelson, Yitzhok 145, 148

Keas call for me (poem) (Jenner) 58

Keneally, Thomas 189, 239

kestl (kessle or castle) 194-195

keys, lost 157, 169

Khalil (political philosopher/shopowner)

190

killing chains 203

King, Michael

and anti-Semitism 228-231, 235-236 
King, Michael (cont.)

At the Edge of Memory 215-218,

228-233, 235-236

research method 230-231

in ultra-orthodox synagogue 230-231, 236

knowledge

Māori 126

slightly shameful 185

Knowles, Deborah (Holocaust survivor's daughter) 194

Koloss von Prora (Hitler's workers' resort on the Baltic) 193

Kosofsky Sedgwick, Eve 220

Kristallnacht 181, 201, 219

Kurtz, Glenn 50, 53

$\mathbf{L}$

Labour government of New Zealand (first)

34

disappointment in 258

elected 27 November 1935 181, 203

Lancaster Bomber 97

land

cleared of forest 121, 149

confiscated 121

falling price of 149

problem of $179-180$

required for settlement 180

thought to contain mass graves 121

language, willing scab 191

languages no-one spoke anymore 101

legal advice 161-162

Lenin, Vladimir 115-117, 118

seated at a great and messy desk 115

Lesbos, island of 42,45

letter, Yiddish 143

Levine, Hal 204, 209

lice, avoiding 183

life

crazy thing 234

or literature 241

supposed to be lived on bedrock 174

lilacs 57, 145

as sweet as the smell of 147

lists 194-195,221, 251-252, 258

significance of 92,178 worn out books 36

Literature or Life (book) (Semprún) 241

Little Boy (atomic bomb) 211

Lochore, Reuel Anson 188, 235-236

From Europe to New Zealand 228-229, 235

Lodz ghetto 185, 238, 250

longing 47

loss (un-indexable)

The Lost: a Search for Six of the Six Million

(book) (Mendelsohn) 195

loyalty 98

LP67 (poem) (Sappho)

translation by Anne Carson 43, 50

translation by Jim Powell 73

wrapped around a mummified crocodile 95

luck 195, 249

lyre 42,45

\section{M}

Macmorran, Barbara 179-180

macrocarpa 71-72

magpies calling from the trees 149

man

homeless 163

landing on the moon 187

naked 169

Māori

children 131

knowledge 126

poetic legends and historical traditions 137

stick games 131

Maori Folk Tales of the Port Hills (book)

(Cowan)

Hone Taare Tikao's help 137-141

illustrations added to the 1954 edition 124

Opaawaho 133-134

published in 1923124

tidbits 126, 137

'wairua,' not 'waiuru' 131

Maslow, Abraham 192

Maslow's Hierarchy of Needs (theory) 187 diagram 192-193

McNeill, Mark "Frosty" 84 
meat 200, 203

Memorial to the Murdered Jews of Europe (sculpture) 199

menacing growl 184-185

Mendelsohn, Daniel 194-195, 227

The Lost 195

quest 195, 226

research methods 226

methodology, see Activity Theory

milk 49, 50, 149, 200, 203

milk cans

Houdini 148

missing 154

up the Whanganui River 149

Warsaw ghetto 147-148

see also Ringelblum Archive

missing people $106,118,121,153,177-$ 258

$95 \%$ found within a few days 168

called away 169-170

commonly found in place with special meaning 168

old haunts 111

Search and Rescue teams 168-171

solitude 111

see also disappearance; reappearance

money 70, 85, 91, 96-97, 100, 135, 246,

249

The Moniac (machine) 96-97

Monroe, Bill 70

morepork 181

mortgage, which never changes 149

Moskovitz, Sarah (Traister) 153

poemsfromhell website 154

translated poems from Yiddish into

English 145-147, 154

see also Ringelblum Archive

mountains

perfect fairy-tale 133

sound of 55

Mulgan, John 215-216

museum industry 72, 245, 247

museums

in Australia 209

camp 256

closing time 96, 209

dedicated to the Holocaust 106, 154,
187, 192-194, 207-210, 237-240

human exhibits 208, 237-238

of money 96

object torn from its context 83

one-way telephones 246, 249

transformational moments 247-249

voice of 183-184, 240

music

assembling tracks 64, 66

chopping 64

collage 70

making beats 63

sampling 59

The muttering poem (poem) (Jenner) 51,

52

mutton and wool prices 156

N

Nash, Walter 204

National Library of NZ 254

natural resources, exploitation 116, 143

New Zealand

anti-Semitism see anti-Semitism

circumcision 244

citizenship 201, 203-205, 235-236

permit to enter 248

safe 199-200, 242

New Zealanders

Jewish 201-204

kindlier and more gentle 244

naïve 239, 242

night bombers 247

nightingales 42

'Nobody' (musician) 63, 64, 66

Now again, grasses wave (poem) (Jenner)

57,60

O

objects

cast-away 67

in context 240

of everyday life 35

fetish 36

lovely and elegant litter 117

man-made 55

most potent 185

one of the most important 256 
Objects (cont.)

precious 37

survived the Holocaust 183

torn from context 83

as works of art 83, 117

Olsson, Linda 223

Open City (book) (Cole) 190

Orpheus 42

Out of the Closet (thrift store chain) 63, 84

over there 86, 188, 206

Oxford University

Ashmolean Museum 77

Queen's College 45, 76

Oxyrhynchus (Egypt) 45, 46, 76

$\mathbf{P}$

Palestine, British Mandate of 233

Palestinian people 189,190

Pākehā

Canterbury 137, 139

half 141

indifference 132

keen to trade 179

see also white-skins

Pall Malls 135

panorama machine 74

papyrus 51, 76

basis of many academic careers 77

fragments of $45,76-77,82,95$

making 95

property of the Egypt Exploration

Society 77

text written in columns 45

value of 95

paranoid reading 220

Paraparaumu Beach 179-180

Parr, James (Sir) 200

Patu-paiarehe (small, fair people) 140

singing fairy songs, playing koauau and putorino 141

Perkins, Carl 70

phase transition, water into steam 173

Phillips, Alban Housego 96, 97

photographs

African boys, about 190380

backshadowing/paranoid reading 220

Christchurch 127
Czernowitz 185-186, 219

Holocaust survivors in Australia 226

Wellington 209

The Picture Chamber of Bruno Schulz (film)

(B Geissler) 94

Pilgrim, Billy 196-197, 234

pines 57

absurdly tall 71

smell of 72

wilding 54

Plaszów (concentration camp) 23

The poem about the candle (poem)

(Jenner) 49, 50

poems 100-101

consolation 101

eaten away 154

reasons for writing 50, 54, 55

Yiddish 147

poemsfromhell website 154

Poland 67

permit to enter 256

Polish/Jewish relationships 92, 150, 151

storks 222, 256-257

see also Drohobych; Warsaw ghetto

Ponton, Francis 205

Poverty Bay Shylock 228

Presley, Elvis 70

proof of what happened 238

see also Ringelblum Archive

Protocols of the Elders of Zion (book) 228229

psychoanalysis

as a form of archaeology 37

traditional 61

Q

Quilter's (secondhand bookshop) 124, 203

$\mathbf{R}$

rabbits, killing 54

'Ras_G' (musician) 63, 64, 66

rats, take sections of the text 154

Raumati 71-72, 98, 165

Raumati Social Club 197

reading Western canon 173

reanimation 51

reappearance, half 172-174 
re-constructions $67,75,94,116$

Jenner 49-53, 57-61, 100-101

of Sappho's poems 46, 62

Secondhand Sureshots 63-64, 66

records 63-64, 66, 84

feminine presences 64

see also songs

Red Zone

businesses in 158-162, 165

dark spot 167

fenced off 127

looting of property 155

unattended phone ringing in 158

refugees 207

from Hitler 203-204, 242, 248-249, 258

Renko, Arkady 117-118

Report on Experience (book) (Mulgan)

215-216

"A Report to an Academy" (short story)

(Kafka) 215-216

Ringelblum, Emanuel

Polish/Jewish relationships 150, 151

somewhat elusive figure 150

Ringelblum Archive (hidden inside the

Warsaw Ghetto) 145, 150-154

archivists and writers of 152,153

intentions 151

'the legend' 152

poemsfromhell website 154

recovery of archive

ten tin boxes 153

two milk cans 154

research guidelines and methods 150-

151

themes and loyalties 151

rings

diamond

lost in the earthquake 155-162, 165-

167

sown into hem of author's coat 167

marcasite 135

risk 223-225

Rosen (Mr) 243-244

Rudderstone (sculpture) (O'Connor) 206

ruin 115

Russia in the Shadows (book) (Wells) 115,

117
Russian

Army Choir 119

atmosphere 119

books 108-109

customs 119

dolls 194

faces 109

national anthem 119

revolution 115

trawlers 109

\section{S}

safe deposit box 156-157

safe, in jeweller shop 158-162

Safran Foer, Jonathan 52-53

sand

smell of 200

white 33

wind-blown 38

Sappho 45, 47, 62, 82

fame of 44

music 45

no bird sang more sweetly than 42

poems 46, 53, 60, 62, 77, 99

$L P 67$ see $L P 67$

speculative performances of her name 45

scandal 90

Schindler's Ark (book) (Keneally) 189

Schindler's List (film) 188

Schpielberg see Spielberg, Stephen

Schulz, Bruno

murals 85-94

possibly sold for $\$ 3,00091$

The Street of Crocodiles 32, 52

sea 200

blue 171, 200, 206

wide 171

searching for something that's missing 58

seasoning 233

dust as 64

Sebald, W.G. 221

Austerlitz 184-185, 198

Secondhand Sureshots (documentary) 63, 64,67

Sedley, Steven 243

Semprún, Jorge 153, 241, 247 
shore birds 171

Sign of the Takahe (building) 129, 133

Six Day War 187, 191

skinks 181

Skoda sports car 256 see also Beran, Karel

Slaughterhouse Five (book) (Vonnegut) 110, 196

slaves $35,85,120$

slowing down a film 184

Small Antiques (poem) (Ulinover) 147

translated by Sarah Moskovitz 146

smoking dope and drinking rum and coke 136

songs $42,100-101,119,131$

death song of Māori warrior 182

versions 70

see also records

sparks 250

at Auschwitz 249

Spielberg, Stephen

mandate to speak 187

Schindler's List 188

Survivors of the Shoah Visual History

Foundation 210, 232

Spitzer, Leo 185-186, 251

Spoonley, Paul 235-236

state house 130

Steiner, George 242

stoats 181

stories 214, 246-247

storks 222, 256-257, 258

The Street of Crocodiles (book) (Schulz) 32,

52

striped coats 183

stump 130

suffocation 190, 193

suitcases 149, 189, 208, 209, 221, 233

living on top of their 221

of refugees 153

surveillance 165-166

Survivors of the Shoah Visual History

Foundation 210, 232, 253-258

swallows 33

swamp dwellers 134

sweetness, almost all gone 148

Sydney Jewish Museum 183 synagogue

King visits 230

set alight 92

T

Takahashi, Akihiro (hibakusha) 211-212

tchemodan see suitcases

Te Naihi Te Owai, Maata 178

Te Rauparaha (chief) 180, 182

Te Urihi (or Te Uruhi) (whaling village at)

179-180

teardrop 211-212

Temple Sinai Poetry Group 145, 154

tendencies 112 readers to extrapolate 189

what is a tendency? 113

Theresienstadt, Nazi Propaganda film about 184

This Crazy Thing a Life (book) (Freadman)

234

thrifting 84

Tikao, Ariana 132

Tikao, Hone Taare (kaumatua of Rapaki)

139

'best informed man of his tribe-

remnant' 137

born in Akaroa 138

division between life and death 142

learned the history and legends of these parts 138

tells Cowan about the Patu-paiarehe 140

as a younger man 138, 141

time

coming unstuck in 196-197

outside of 198

resisting 198

Todesfuge (poem) (Celan) 183, 250

Toller, Ernst 221

Tolstoy, Leo

Anna Karenina 108-109

his flat tone 107

tools

army entrenching 81

cell phone 159

computers 159

disposable camera 127 


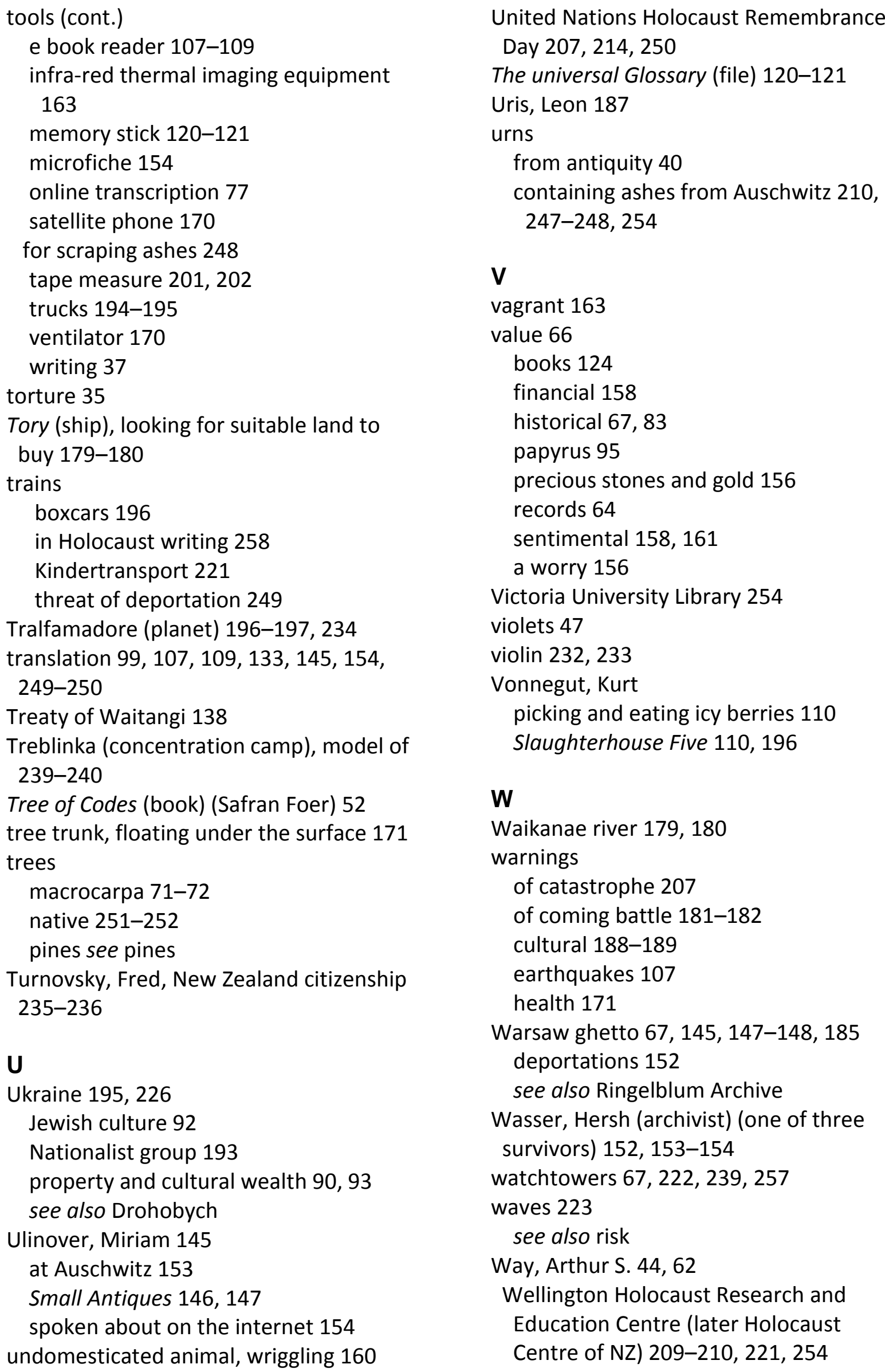

United Nations Holocaust Remembrance

Day 207, 214, 250

The universal Glossary (file) 120-121

Uris, Leon 187

urns

from antiquity 40

containing ashes from Auschwitz 210, 247-248, 254

\section{V}

vagrant 163

value 66

books 124

financial 158

historical 67,83

papyrus 95

precious stones and gold 156

records 64

sentimental 158, 161

a worry 156

Victoria University Library 254

violets 47

violin 232, 233

Vonnegut, Kurt

picking and eating icy berries 110

Slaughterhouse Five 110, 196

W

Waikanae river 179, 180

warnings

of catastrophe 207

of coming battle 181-182

cultural 188-189

earthquakes 107

health 171

Warsaw ghetto 67, 145, 147-148, 185 deportations 152 see also Ringelblum Archive

Wasser, Hersh (archivist) (one of three survivors) 152, 153-154

watchtowers 67, 222, 239, 257

waves 223

see also risk

Way, Arthur S. 44, 62

Wellington Holocaust Research and Education Centre (later Holocaust Centre of NZ) 209-210, 221, 254 
Wellington Railway Station 120

Wells, H. G.

invited for dinner 118

Russia in the Shadows 115, 117

travels to the Kremlin and meets Lenin

115-117

West, Martin 46

Whareroa Farm (Raumati) 251

white light 171

white-skins, bags of gold sovereigns, land-

sale deeds 141

Who Sow in Tears (book) (Akiba) 243-244

wild duck 134

Wildhack, Montana 196-197

Wilkinson, Amy (Mrs) 180-181, 200

will, test of 171

winds

freezing cold 133

known for their melodies 42

night 57

warm scented 47

Winton, Erna (cousin of David

Belgrave/Moshe Belgoraj's niece) 230,

231-233

wolves 232, 233

Woolley, Leonard (Sir) 38, 81, 83

words

all the most beautiful 59, 60

from another poet's book 60

as a cover for emptiness 152

desire to write 152

floating 100

jumping 50

man's best possession 152

no one knew where they would go 170

old 100-101

repugnance of 152

soaked in this darkness 52

which survived the flames 59

writing, in old languages 171

Y

Yad Vashem (museum) 90-94, 245

Yahrzeit, candle 48, 49, 50

yellow star 184-185, 185

Yiddish language 141, 143, 232, 234

Yinglish 153
Younce, Bryan "Morpho" 84

YouTube 45, 115

Z

Zhivago (Dr) 117, 118 


\section{Report on experience (an afterword)}

In this section I reflect on theoretical issues associated with writing about the Holocaust that have arisen during the process of research and in the writing. I will compare the work in this dissertation with my aims for it, discuss some limitations and outline my current views of these texts. I will also discuss future research possibilities.

First I will consider the question of why a writer, and specifically this writer, would choose to write about the Holocaust despite the extremely contentious arguments that continue to rage about any artistic representation of this event. This question lies behind and appears in the text of this dissertation. It is of most relevance to "Cairn", but applies to some extent to all four parts.

I have chosen to take the risky path of writing about the Holocaust in this dissertation, despite not being in any sense a victim of it. This decision was made in several steps. The first was that once I identified the topic as 'missing people', the Holocaust immediately asserted its claim to be the biggest missing people story in my consciousness. I felt compelled to investigate it for myself, especially its New Zealand connections. By writing about this, I broke, for myself, the silence which surrounded the subject in New Zealand, and in many other places, during my childhood. In fact the cover of silence turned out to be very thin, even in New Zealand where we are good at silences, and behind it there were many voices to be heard. I could have done all of this research privately but chose to do it in the context of a PhD writing project because that structure gave me support of various sorts to bring reading and research and writing on a topic together. The assistance of a university library, for example, helped me to read books not widely held in local libraries. I also felt that the PhD gave me a mandate to write about a topic which may not have much interest for the New Zealand book-buying public.

The second stage of the decision was this: If a group does not tell and re-tell its stories, the stories will be lost. Countering this process is an explicit motivation behind the deliberate transmission of folk tales and history. Retention of memories is one of the motivations behind the Ringelblum Archive, Sarah Moskovitz's translations of the Yiddish poems and the establishment of Holocaust museums and exhibits. It is also referred to by the Māori speaker at the Holocaust Memorial Service at Makara. If stories are told, they stay in the collective memory for longer, but are smoothed and changed in the telling. 
In addition, as soon as they are told, the teller loses control over how they will be interpreted. I opted for telling, with all its risks.

I have found it particularly interesting to read stories related to the Holocaust (albeit indirectly) by other New Zealand and Australian writers such as Thomas Keneally and Michael King. I have brought together and told some stories that interest me. No other collection would be the same. The stories I have chosen will be on the surface for a few moments, and when buried again, will be available to anyone who searches. My writing, on the Holocaust and its survivors and on New Zealand policy and attitudes to those survivors, draws on and is in conversation with people from New Zealand and beyond. It is able to do this because of the work of Francis Ponton, Ann Beaglehole, Jessica Caldwell, 'Ben Akiba', The U.S.C. Shoah Foundation Institute for Visual History and Education, the Jewish Communities of Sydney, Melbourne, Wellington and Auckland and their museums, the six survivors whose stories I heard, The Holocaust Centre of New Zealand, the National Library Oral History Collection, other individuals in the Holocaust heritage area and a number of writers, poets and translators. Each person or text tells only part of the story but my experience is that if you find one of these resources, you tend to find more, because they lead to each other.

I took several deliberate ethical precautions in work related to the Holocaust. I kept my focus on aspects which could either be seen from New Zealand or in published form. I did not attempt to write about the topic of the Holocaust as a whole. I did not attempt to fictionalise accounts. I never described life or death in the camps as if I knew about these things, mostly I kept my gaze on Jews rather than on the Nazis, and I tested the work on a range of Jewish readers and asked for their feedback, since it is generally Jewish readers who hold Holocaust writing accountable in the most serious way. I also read a variety of writing on the subject, including work such as William Styron's Sophie's Choice, which has drawn criticism for its depiction of the Holocaust. I was never tempted to draw any overarching conclusion about the meaning of the Holocaust, although I did end up facing the question of the existence of evil.

Initially, I had entertained the idea of writing "Cairn" as a long poem. But, when faced with all the artistic and ethical risks and a bag full of information from my research, the only voice I could find was a version of my own, which recorded my research and reactions fairly directly. I regard this use of a personal narrative as an artistic decision made under the 
influence of two factors: stern ethical critiques in the literature on Holocaust writing and the existence of much survivor writing about the Holocaust in personal narrative form. I thought this non-fiction voice would kept me safe from a number of the risks and I believe it did, but it brought risks that the work would be flat, dull and too serious for any but the most dedicated Holocaust reader and that it would seem to make the Holocaust 'all about me'.

In this project there were two additional risks. First that any research that included the Holocaust would be impossible to contain because of the sheer size of its history and literature and second that any writing which included mention of the Holocaust would be completely dominated by this topic, since it is often spoken about as a phenomenon which 'trumps' all other topics. The potential size of the research task has been a challenge. Any end to reading on this subject would be arbitrary so I expect that I will be reading on this topic forever. I could also write about this research for ever. I have tried to illustrate this in the attempts at endings in "Cairn". It interests me that "Cairn" is significantly larger than any of the other texts. Whether "Cairn" with its Holocaust-Holocaust-Holocaust focus dwarfs or overwhelms the other texts or draws the reader towards the topic as it drew me, is an interesting question, and one to which I do not have an answer yet. Perhaps there are too many kinds of reader for the question to be meaningful?

While writing "Cairn", I noticed that many of the tropes of Holocaust writing found their way into the work: railways, suitcases, lost manuscripts, fires, selection, photographs of the life 'before', for example. This replication disturbed me when I first noticed it, and I wondered if I was researching and writing towards these ideas because I expected them to be there. I also wondered, and I mention this in the text, whether these tropes exist because many people's experiences contained them. My current theory is that these objects or themes are in many accounts because they happened to many people, and that my consumption of Holocaust stories over the years has left me with a sensitivity to those phenomena when I hear them or read them. Other, less frequently spoken about or less widely known themes, such as redistribution of wealth as a factor in the Holocaust, pass me by until I have heard them enough times to start to notice them.

In the course of this project I developed and experimented with writing which was both creative and critical, the term 'critical' describing a pervasive posture which I adopt in my writing rather than specifically literary criticism. Working from this stance positioned the whole project as a fluid and free-ranging form of action research, where the reader is 
invited to share the author's developing understanding of particular subjects. This way of writing has given me great flexibility in choosing which subjects I address and how I wished to approach any particular subject.

Any genre decision, even a decision to mix or break genres, brings with it some measure of constraint, but I do not think the 'hybrid critical and creative' concept has been a damaging constraint in developing this project. I have assumed that certain sections of writing could move further towards the creative and others further towards being critical, but the project as a whole could still be within this hybrid territory. For reasons I have already discussed, "Cairn" seemed unable to be written as anything but non-fiction, but I was able to write about other subjects in poems and in somewhat poetic prose. Whether readers will accept so much movement of form and so many variations of topic as adding up to one piece of writing, I am not able to say at this stage.

"The autobiographical museum", "History-making" and "Cairn" are all written in the first person. This has the benefit of giving the reader easy access to the process of the research and the author's reactions to research findings, but because the reader cannot travel further than the author's consciousness as it is presented, there is a risk that the work is too limited to be interesting or too self-absorbed to be acceptable to readers. I hope that the focus on the research itself and the breadth of sources in Everyday Life in the Ancient World will mitigate the risk of narrowness, but in the end I cannot judge whether the whole project is offensively self-absorbed. It interests me that breadth mitigates the risk of narrowness, but makes the risk of incoherence or loss of critical mass greater.

The use of fragmentation is another strategy with its own risks. I set out to make text that 'represented loss and absence' in its mood, appearance and fragmented structure. Each of the four texts is different in appearance and in its degree of fragmentation. From my perspective "The autobiographical museum" provides the clearest visual representation of loss, its white spaces and lack of joining narrative mirroring the effect of the passage of time and the odd ways in which objects that are lost re-surface and are re-claimed. "Cairn" and "History-making" are stronger evocations of loss in the sense of grief. Access to the writer's grief is greater in these texts in part because there is less fragmentation. The Index is fragmented in the sense that information is presented in chunks rather than in sentences, but is the only part that speaks of and for the whole project. 
This project aimed to examine 'loss, searches and re-constructions'. It seems to me that all four texts and the project as a whole are inside that definition of scope. The first person voice of the author joins Parts One, Two and Three. Because the author has selected the items for inclusion in the Index, this text is another authorial output. This gives the Index unity with the other three texts in its content and therefore its mood, even though its appearance is very different from the other three texts. As intended, each of the four texts places different topics in the foreground but all four texts are joined by the themes of loss, searches and re-constructions, by research, reading, and writing activities and by the pull of the Holocaust.

David Markson (Reader's Block), Anne Carson (Nox) and David Shields (Reality Hunger: A Manifesto) all assemble quotations and author-written text to make new work. From my perspective the notion that a piece of text is an object is entirely satisfying. Any text, when viewed in this way, has cultural meanings, historical meanings and also aspects of mystery where the cultural and historical meanings are lost or are in dispute. In a curated collection of text like mine, where there is no character development or plot as readers would expect in a novel and little of the coherence they might expect in non-fiction, readers must search the genre, register, sound patterns, rhythm, literal and metaphorical content and shape on the page for the meanings of individual texts and of the text as a whole. Readers do this in any reading experience, but perhaps more actively and more consciously in a text like Everyday Life in the Ancient World.

The attractiveness or perceived significance of the individual texts and their placement relative to each other are going to be important in determining readers' reactions to this sort of work. From a creative point of view, it is too soon for me to be able to reach any summative conclusions about whether the quoted texts are attractive enough, my own texts well enough written and the placements successful.

I am confident that my aim of making text rich in psychological, cultural and historical context has been achieved, although, as with my other artistic decisions, this one has its own risks, in this case that the work will be too far into a Jewish cultural and historical world view for non-Jewish New Zealand readers, and not far enough for some Jewish readers.

I do not have a sense that this writing is finished and complete. Instead, I have put down my pen for a few months, following which I expect to return to it having experienced some detachment and received some new feedback. At this next stage I will consider the 
various balances I have been discussing alongside the question of how best Everyday Life in the Ancient World might be published.

As I have outlined, writing in this dissertation balances over a number of crevasses. Each time it moves in a certain direction, different risks are apparent. The fact that there is such a small margin for artistic and ethical error is undoubtedly one of its limitations, especially in the hands of a relatively inexperienced writer.

In the future I will be researching options for how best to present this work. The question of how closely a version of Everyday Life in the Ancient World for trade publication might resemble the PhD version will need to be considered. The Index, for example, could be re-balanced - moved further towards its creative aims at the expense of some of its thoroughness and functionality.

I wonder what could be gained by using digital publication as opposed to paper publication. Could I make a text where readers chose their own path? If a reader could investigate his or her own selection of the topics I raise by following certain tags or links and not others, what effects would a process like that have on the reading experience? What impact would it have on my selection of topics, or my volume of text, if I knew readers could do this? Could I make a separate visual Index, where readers could link to a list of images of buildings or artworks mentioned in the text? What cost would be involved in permissions for that? Could I make a package of digital material, for example an access code to a digital version of the text, which accompanies the printed text when it is sold?

In another domain altogether, there is potential for investigation of visitor experiences in Holocaust museums and for considering the effects of the imminent disappearance of Holocaust survivors from museums. The questions of whether and for how long Holocaust museums should or can remain separate from other general Jewish history museums and how best to communicate with non-Jewish audiences about the Holocaust are other areas for future research.

It is a cliché for people to say how much they have learned from any project, but at this point in this project I would say I have now understood that this is an interdisciplinary dissertation which is not so much 'about' the Holocaust as it is 'about' the process of one particular person encountering the Holocaust. 
Appendix 


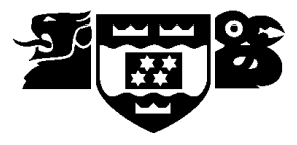

\title{
Participant Information Sheet for a study of memorials to the Holocaust in Australia and New Zealand in the form of creative writing.
}

\section{Researcher: Lynn Jenner: International Institute of Modern Letters, Victoria University of Wellington, New Zealand}

I am a PhD student in creative writing at Victoria University of Wellington. I am a member of Temple Sinai, Wellington's progressive Jewish congregation. I have previously published a poetry collection called Dear Sweet Harry. I am trained in Oral History interviewing.

\section{My project:}

As part of my PhD I will be writing a thesis. The thesis explores, in poetry and other creative forms, the way human beings search for, document and re-construct what is lost.

\begin{abstract}
I am carrying out research into the representations of the Holocaust in Australia and New Zealand. I will be visiting four museums. These are; The Sydney Jewish Museum, the Jewish Holocaust Museum and Research Centre (Melbourne) the Jewish Museum of Australia (Melbourne) and the Wellington Holocaust Research and Education Centre in Wellington, New Zealand.
\end{abstract}

Visits to these four museums and interviews with museum staff will be used as background for my creative writing.

After the thesis is completed I hope to publish parts or all of it as a book of poetry and essays.

Who will be invited to take part in this research?

At each of the four museums I will invite staff in roles relating to Education, exhibition planning, archives or any other staff suggested by the Director of that Museum, to participate in my research study.

I am also intending to invite holocaust survivor guides at these museums to participate in the study.

The interviews:

Participants will be invited to take part in one interview concerning the original intentions, current aims and current activities of the Museum in relation to the Holocaust. I anticipate each of these interviews will take up to an hour.

Survivor guides will also be asked to take part in one interview. The interview will ask about their motivation for taking the volunteer guide role in that particular museum and the reactions they observe in visitors to their guide work.

How the interviews will be used:

Interviews will be used as background for my creative writing.

The thesis will not use your name, and no opinions will be attributed to you in any way that will identify you, unless you have given specific permission for the use of a quotation and the institution for which you work has also given consent for the attribution.

In that situation I will provide a draft of the text I would like to use for your approval and the approval of the museum. Should either party decline permission I will not use the text.

Rights of participants:

I will provide you with a summary of your interview. Please tell me if you do NOT wish to receive this. 
The events of the Holocaust mean that the interviews could be distressing. If you wish to stop the interview at any time, please tell me. You are welcome to bring another person with you to the interview.

If you wish, you can stop an interview and withdraw from the research project at any time, without being questioned.

I would like to take notes during the interview. If you do not wish me to take notes during the interview, or if there is a something which you do not want me to write down, please tell me.

Participants can also withdraw their interviews from the project, without question, at any time before June 302012.

If you wish to withdraw from the project please tell me at any time before June 302012 . My contact details are at the bottom of this form.

No other person besides me and my supervisors, Professor Bill Manhire and Chris Price, will see the interview notes.

\section{Storage of interviews:}

No audio or video recordings will be made of the interviews. Interview notes in paper form will be kept in a locked cabinet in a locked office at Victoria University until one year after the thesis is placed in the university library. At that time I will shred the interview notes, using the Universities confidential document disposal system. Interview notes in electronic form will be stored in password protected documents accessed only by me. These documents will be deleted one year after completion of the PhD.

\section{Victoria University Human Ethics Committee:}

The University of Victoria, Wellington, New Zealand, requires that ethics approval be obtained for research involving human participants. The University Human Ethics committee has approved my project.

\section{The thesis:}

The thesis will be submitted for marking to the Faculty of Post Graduate Studies and deposited in the Victoria University Library. It is intended that the thesis will be the basis of a book. Excerpts from the thesis will be submitted for publication in scholarly or literary journals.

If you have any questions or would like to receive further information about the project, please contact me at lynn.jenner@vuw.ac.nz

phone 049054954

international ++64-4-9054954

or

my primary supervisor, Professor Bill Manhire at

Bill.Manhire@vuw.ac.nz or at

The International Institute of Modern Letters

Victoria University,

P O Box 600, Wellington,

phone 044636308

international ++64-4-4636308 


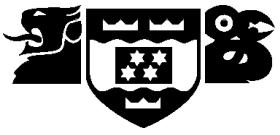

\section{CONSENT FORM}

Project: a study of memorials to the Holocaust in Australia and New Zealand in the form of creative writing.

Researcher: Lynn Jenner, International Institute of Modern Letters, Victoria University, Wellington, New Zealand

O I have been given and have understood an explanation of this research project.

O I have had an opportunity to ask questions and have them answered to my satisfaction.

O I understand that I may withdraw myself (or any information I have provided) from this project before June 30,2012 , without having to give reasons or without penalty of any sort.

O I understand that any information I provide will be kept confidential to the researcher and her two supervisors.

O I understand that the published results will not use my name, and that no opinions will be attributed to me in any way that will identify me, unless I have given specific permission for the use of a quotation and the institution for which I work has also given consent for the attribution.

O I understand that the interview notes in paper form will be destroyed a year after completion of the $\mathrm{PhD}$.

O I understand that electronic documents containing interview notes will be deleted by the researcher one year after the completion of the PhD.

O I understand that the data I provide will not be used for any other purpose.

\section{O I agree to take part in this research}

Signed:

Name of participant:

(Please print clearly)

Date:

I would like the Interview Summary to be sent to the address below: 


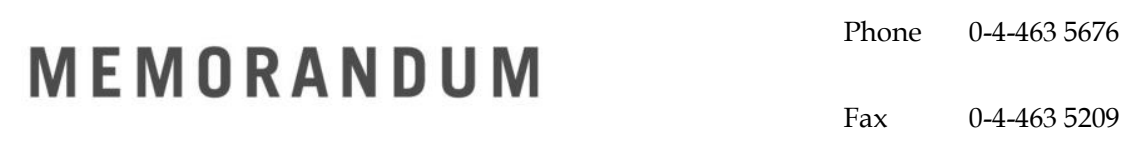

\begin{tabular}{l|l}
\hline TO & Lynn Jenner \\
\hline COPY TO & $\begin{array}{l}\text { Bill Manhire } \\
\text { Chris Price }\end{array}$ \\
\hline FROM & Dr Allison Kirkman, Convener, Human Ethics Committee \\
\hline DATE & 7 August 2011 \\
\hline PAGES & 1 \\
\hline & \\
\hline SUBJECT & $\begin{array}{l}\text { Ethics Approval: } 18692 \\
\text { The Universal Glossary }\end{array}$ \\
\hline
\end{tabular}

Thank you for your application for ethical approval, which has now been considered by the Standing Committee of the Human Ethics Committee.

Your application has been approved from the above date and this approval continues until 28 February 2013. If your data collection is not completed by this date you should apply to the Human Ethics Committee for an extension to this approval.

Best wishes with the research.

Allison Kirkman

Human Ethics Committee 


\section{Works Cited}

"African boys, about 1903." Photograph and caption. HuntleyandPalmers.org.uk. n.d., n.p. Web. 22 May 2010.

A. W. H. (Bill) Phillips, MBE and The Moniac. Wellington: Reserve Bank Museum, date unknown. Print.

"Ancient Lives." ancientlives.org. University of Oxford. n. d. n. pag. Web. 10 Sept. 2012.

And Europe Will Be Stunned. Dir. Yael Bartana. 2007-2011.

Akiba, Ben. Who Sow in Tears. Wellington: Eshape Publishing Co., 1944. Print.

Beaglehole, Ann. A Small Price to Pay: The Refugees from Hitler in New Zealand 1936-1946. Wellington: Allen \& Unwin New Zealand Ltd. and Historical Branch, Department of Internal Affairs, New Zealand. 1988. Print.

---. "The Response of the New Zealand Government to Jewish Refugees and Holocaust Survivors, 1933-1947." Holocaustcentre.org.nz. n.p., n.d. Web. 12 Oct. 2012.

Beaglehole, Ann, and Hal Levine. Far From the Promised Land: Being Jewish in New Zealand. Wellington: Pacific Press Ltd., 1995. Print.

Beattie, Herries. Tikao Talks: Traditions and Tales of the Canterbury Maoris as Told by Teone Taare Tikao. Wellington: A. H. \& A. W. Reid, 1939. Print.

Benjamin, Walter. "No.113." One-Way Street and Other Writings. Trans. Edmund Jephcott and Kingsley Shorter. London: Verso, 1979. Print.

Beran, Karel. (see Karel, B.)

Bernstein, Michael André. Foregone Conclusions: Against Apocalyptic History. Berkley: University of California Press, 1994. Print.

"Blue Jeans". Thoughts from the High Country. 1995. Naseby, New Zealand, 1999. Print. 
Bohlen, Celestine. "Artwork by Holocaust Victim is Focus of Dispute." Nytimes.com. 20 Jun. 2001. New York Times. n. pag. Web. 26 Oct. 2012.

Brett, Thomas. Brettworks.com. 11 Feb. 2011. Web. 30 Jul. 2012.

Bruell, Claire. Message to the author. 7 Mar. 2012. E-mail.

Caldwell, Jessica. Holocaust Consciousness in New Zealand 1980-2010: A Study. MA thesis. Victoria University of Wellington, 2011. Print.

Carkeek, Wakahuia W. The Kapiti Coast: Maori History and Place Names of the PaekakarikiOtaki District. 2nd ed. Auckland: Reed Books, 1967. Print.

Carson, Anne. If Not, Winter: Fragments of Sappho. Trans. Anne Carson. New York: Vintage Books, 2003. Print.

Casey, Kate. "Karel Beran." Message to the author. 26 Oct. 2012. E-mail.

Clendinnen, Inga. Agamemnon's Kiss: Selected Essays. Melbourne: The Text Publishing Company, 2006. Print.

Cole, Teju. Open City. London: Faber and Faber Ltd., 2011. Print.

Cowan, James. Maori Folk Tales of the Port Hills. 1923. Christchurch: Whitcombe and Tombs Limited, 1954. Print.

Davin, Dan. Not Here, Not Now. London: Robert Hale, New Zealand: Whitcombe \& Tombs Ltd., 1970. Print.

Davenport, Guy. Preface. Sappho, Poems and Fragments. Trans. Guy Davenport. Ann Arbor: The University of Michigan Press, 1965. Print.

Du Bois, Page. Slaves and Other Objects. Chicago: The University of Chicago Press, 2003. Print.

Felstiner, John. Paul Celan: Poet, Survivor, Jew. New Haven and London: Yale University Press, 1995. Print.

Finding Pictures. Dir. Benjamin Geissler. Benjamin Geissler Filmproduktion, 2001. DVD. Freadman, Richard. This Crazy Thing a Life: Australian Jewish Autobiography. Crawley: University of Western Australia Press, 2007. Print. 
Freud, Sigmund. "A Disturbance of Memory on the Acropolis." (1936) Standard Edition of the Complete Psychological Works. 2nd ed. Trans. J. Strachey. London: Hogarth Press and The Institute of Psychoanalysis, 1964. 22: 239-248. Print.

Geissler, Benjamin. “Drohobycz.” Benjamingeissler.de. n.p. Web. 9 Sept. 2012.

Hirsch, Marianne, and Leo Spitzer. Ghosts of Home: The Afterlife of Czernowitz in Jewish Memory. Berkley: University of California Press, 2010. Print.

"Hooligans beef up for English football invasion." The Dominion Post 14 May 2012: B3. Print.

"Israel and Ukraine Sign Agreement Today on Bruno Schulz Works Located at Yad Vashem." yadvashem.org. 28 Feb. 2008. Web. 26 Oct. 2012.

Judt, Tony. Preface. Postwar: A History of Europe Since 1945. London: Vintage, 2010. Print. Kafka, Franz. "A Report to an Academy." The Complete Short Stories of Franz Kafka. London: Vintage Classics, 2005. Print.

Karel, B. 1997, "Interview by Survivors of the Shoah Visual History Foundation," Auckland, New Zealand, 10 Dec, Videotape.

Kassow, Samuel D. Who Will Write Our History? Rediscovering a Hidden Archive from the Warsaw Ghetto. New York: Vintage Books, 2009. Print.

Katznelson, Yitzkhok. "Introduction to an Evening of Tanakh." (26 Nov. 1940) Trans. Sarah Traister Moskovitz. poetryinhell.org. n.p., n.d. Web. 16 Oct. 2012.

Keneally, Thomas. Searching for Schindler: A Memoir. Sydney: Random House Australia, 2007. Print.

King, Michael. At the Edge of Memory: A Family Story. Auckland: Penguin Books, 2002. Print. 
---. “The Strange Story of Reuel Anson Lochore.” Metro (NZ) 117. March (1991): 114-125. slaw.vdxhost.com. Web. 14 May 2012.

Knowles, Deborah. Introduction. Mixed Blessings: New Zealand Children of Holocaust Survivors Remember. Ed. Deborah Knowles. Auckland: Tandem Press, 2003. Print. Kosofsky Sedgwick, Eve. "Paranoid Reading and Reparative Reading, or, You're So Paranoid, You Probably Think This Essay Is About You." Touching Feeling: Affect, Pedagogy, Performativity. Durham, N.C.: Duke University Press, 2003. Print.

Kurtz, Glenn. "What Remains: 'Sappho and Mourning”. Southwest Review 95. 1 \& 2 (2010): n.pag. poems.com. Web. 08 Feb. 2011.

Liba, Moshé. The Holocaust - Between Me and Myself. Wellington: New Zealand Jewish Chronicle Publications, 2000. Print.

Lochore, Reuel A. From Europe to New Zealand: An Account of our Continental European Settlers. Wellington: A. H. \& A. W. Reed, 1951. Print.

Macmorran, Barbara. In View of Kapiti. Palmerston North, N.Z.: The Dunmore Press, 1977. Print.

“Maslow's Hierarchy of Needs." changingminds.org. n.p., n.d. Web. 20 Oct. 2012.

Marx, Karl and Friedrich Engels. 1848. The Communist Manifesto. Trans. Samuel Moore. London: Orion Books. 1996. Print.

Mendelsohn, David. The Lost: A Search for Six of the Six Million. New York: Harper Collins Publishers, 2006. Print.

Mulgan, John. Report on Experience. Wellington: Victoria University Press, 2010. Print. Nash, Walter. Letter to Mrs J. Hall, Secretary, Hororata Branch of the New Zealand Labour Party 21 March 1939. Qtd. in Beaglehole, Ann. A Small Price to Pay: Refugees from 
Hitler in New Zealand 1936-46. Wellington: Allen \& Unwin New Zealand Ltd. and Historical Branch, Department of Internal Affairs, New Zealand. 1988. Print. O’Connor, Denis. Rudderstone. 1997. Botanic Garden, Wellington. Sculpture.

Olsson, Linda. The Kindness of Your Nature. Auckland: Penguin Group (NZ), 2011. Print. O'Regan, Tipene. "Tikao, Hone Taare - Biography." www.Te Ara.govt.nz. n.p. 1 Sept. 2010. Web. 3 Sept. 2011.

O'Sullivan, Vincent. Long Journey to the Border: A Life of John Mulgan. Wellington: Bridget Williams Books Ltd., 2011. Print.

poetryinhell.org. n.p., n.d. Web. 16 Oct. 2012.

Ponton, Francis Arthur. "Immigration Restriction in New Zealand: A Study of Policy from 1908-1939." MA thesis. University of New Zealand (Victoria), 1946. Microfilm.

Powell, Jim. Sappho: A Garland: The Poems and Fragments of Sappho. Trans. Jim Powell. New York: Farrar Strauss Giroux, 1993. Print.

Rev. of From Ur to Rome, by Kathleen M. Gadd. Greece and Rome 7. 20 (1938): 123. Cambridge Journals Online. Web. n.p. n.d. 14 Sept. 2012.

Reynolds, Margaret. The Sappho Companion. New York: Palgrave, 2001. Print. Schulz, Bruno. "Spring." The Street of Crocodiles and Other Stories. Trans. Celina Wieniewska. London: Penguin Books, 2008. Print.

Sebald, W. G. Austerlitz. Trans. Anthea Bell. New York: Modern Library, 2001. Print.

"Secondhand Sureshots: Each Snap, Crackle and Pop Tells The Story."larecord.com. 7 Dec. 2008. n.p., n. pag. Web. 28 Jun. 2010.

Sedley, Steven. "Reflecting on the World: Jewish Writers." Jewish Lives in New Zealand. Ed. Leonard Bell and Diana Morrow. Auckland: Random House New Zealand, 2012. Print. 
Semprún, Jorge. Literature or Life. Trans. Linda Coverdale. New York: Penguin Books, 1997.

Print.

Sheppard, Ruth. Explorer of the Mind: The Illustrated Biography of Sigmund Freud. London: Andre Deutsch, 2012. Print.

Spoonley, Paul. "Anti-Semitism at the End of the World: The Politics of Prejudice in New Zealand." Jewish Lives in New Zealand. Ed. Leonard Bell and Diana Morrow. Auckland: Random House New Zealand, 2012. Print.

Steiner, George. "The Hollow Miracle" Language and Silence: Essays 1958-1966. London: Faber and Faber. 1967. Print.

Sweenykovar. Sweeneykovar.wordpress.com. n.p. 29 Oct. 2007. Web. 28 Jun. 2010.This blog has now been deleted.

Swiggs. "Demolition of heritage buildings." www.rebuildchristchurch.co.nz/blog. n.p.

15 March 2011. Web. 29 August 2011. The discussion is no longer able to be accessed. tindall.org.nz. n.p., n.d. Web. 01 May 2012.

Ulinover, Miriam. "Small Antiques." (1922) Trans. Sarah Traister Moskovitz. poetryinhell.org. n.p. n.d. Web. 16 Oct. 2012.

"Voice for the Silenced." The Christchurch Press 31 Dec. 2011: B13. Print.

Wachtel, Eleanor. "Ghost Hunter." The Emergence of Memory: Conversations with W. G. Sebald. Ed. Lynn Sharon Schwartz. New York: Seven Stories Press, 2007. Print.

Wagner, Heather. "Jonathan Safran Foer Talks Tree of Codes and Conceptual Art." Vanityfair.com. Vanity Fair 10 Nov. 2010. Web. 23 Jun. 2011.

Way, Arthur S. Introduction. Sappho, Vigil of Venus. Trans. A.S. Way. London: Macmillan and Co. Limited, 1920. Print. 
Wedde, Ian. "The Ballad of Worser Heberley." Sport 9 (1992): 11-15. Print.

Wells, H. G. Russia in the Shadows. London: Hodder and Stoughton Limited, n.d. Print.

West, Martin. “A New Sappho Poem.” The-t/s.co.uk. 24 Jun. 2005. Web. 10 Dec. 2010.

"When is a Biscuit Tin Not a Biscuit Tin?" HuntleyandPalmers.org.uk. n.d., n.p. Web. 22 May 2010.

Wilkinson, Amy K. Kapiti Diary. Ed. R. H. D. Stidolph. Masterton, N.Z.: Masterton Printing Co. Ltd., 1957. Print.

Woolley, Leonard. Digging up the Past: The Romance of Archaeology. London: Pelican Books, 1937. Print.

wwf.org.nz. n.p.,n.d. Web. 1 May 2012.

Young, James E. Writing and Rewriting the Holocaust: Narrative and the Consequences of Interpretation. Bloomington: Indiana University Press, 1988. Print.

Zable, Arnold. Scraps of Heaven. Melbourne: Text Publishing, 2004. Print. 


\section{Selected Bibliography}

(* indicates additional resources suggested by the examiners, or added by the author in response to additional resources)

Abramowitz, Michael, and Mark Sarna. "Why Cambodia Trial Matters." The Dominion Post 24 Nov. 2011: B5. Print.

Adams, Graham, and Margo White. Rev. of At The Edge of Memory, by Michael King. Metro (NZ) May 2002: n.pag. Australia/New Zealand Reference Centre. EBSCO database. Victoria University of Wellington Lib. Web. 14 June 2012.

Adler, H. G. Panorama. Trans. Peter Filkins. New York: Random House, 2011. Print. ---. The Journey. Trans. Peter Filkins. New York: Random House, 2008. Print. Appelfeld, Aharon. The Story of a Life. Trans. Aloma Halter. New York: Schocken Books. 2004. Print.*

Aüslander-Stiftung, Rose, and Helmut Braun. „, Mutterland Wort” : Rose Aüslander 1901-1988. Üxheim-Eifel: Rose-Aüslander-Dokumentationszentrum, 1999. Print.

Bäcker, Heimrad. transcript. Ed. Friedrich Achleitner. Trans. Patrick Greaney and Vincent Kling. London: Dalkey Archive Press, 2010. Print.

Baird, Kingsley, and Caroline Campbell, eds. Contained Memory Conference 2010 Proceedings: Programme and Abstracts. Wellington: Massey University, Syracuse University and Museum of New Zealand Te Papa Tongarewa, 2010. Print.

Barthes, Roland. "The Death of the Author." Essay in Image-Music-Text, by Roland Barthes. Trans. Stephen Heath. New York: Hill and Wang, 1977. deathoftheauthor.com. n.p., n.d. Web. 12 Oct. 2012.

Batuman, Elif. "Short Story \& Novel: American Writing Today." n+1 01 June 2006: n.pag. nplusonemag.com. Web. 17 Aug. 2010. 
Bell, Leonard, and Diana Morrow, eds. Jewish Lives in New Zealand: A History. Auckland: Godwit, 2012. Print.

Berman, Judith. Holocaust Remembrance in Australian Jewish Communities, 1945-2000. Perth: University of Western Australia Press, 2002. Print.

Blunden, Andy. An Interdisciplinary Theory of Activity Theory. 2009. Chicago: Haymarket Books, 2012. Print.

Binet, Laurent. HHhH. Trans. Sam Taylor. London: Harvill Secker, 2012. Print.

Bönisch-Brednich, Brigitte. Keeping a Low Profile: An Oral History of German Immigration to New Zealand. Wellington: Victoria University Press, 2002. Print.

Brewer, John. "Microhistory and the Histories of Everyday Life." Cultural and Social History 7.1 (2010) 87. Web. 8 May 2013.*

Bruncevic, Merima. "The Lost Mural of Bruno Schulz: A Critical Legal Perspective on Control, Access to and Ownership of Art." Law Critique 22 (2011): 79-96. Print.

Carson, Anne. Nox. New York: New Directions, 2010. Print.

Classic Hassidic Tales. Trans. Meyer Levin. New York: Penguin Books, 1975. Print.

Clendinnen, Inga. Reading the Holocaust. Cambridge, United Kingdom: Cambridge University Press, Canto edition 2002. Print.

Cooke, Michelle. "Cambodia Tries to Forget its Killing Fields." The Dominion Post 4 Feb. 2012: A8. Print.

Cooke, Rachel. “Dave Eggers: From 'Staggering Genius' to America's Conscience.” Rev. of Zeitoun, by Dave Eggers. The Observer 7 Mar. 2010: n. pag. www.guardian.co.uk. Web. 30 April 2012. 
Cusk, Rachel. Rev. of All That I Am, by Anna Funder. The Guardian 16 Sept. 2011. www.guardian.co.uk. Web. 14 Dec. 2011.

Dark, Sidney and Herbert Sidebotham. The Folly of Anti-Semitism. London: Hodder and Stoughton, 1939. Print.

Dekker, Diana. "Homes Are Where Her Heart Is." The Dominion Post 14 Jan. 2012: Your Weekend. 6. Print.

De Waal, Edward. The Hare With Amber Eyes. London: Vintage Books, 2011. Print.

Dyer, Geoff. "Sebald, Bernhard, and Bombing." Brick May 2005: 92-96. Print.

Eaglestone, Robert. The Holocaust and the Postmodern. New York: Oxford University Press Inc. 2004. Print.*

Editor. "Exclusive: The Missing Pages of Laurent Binet's HHhH." The Millions. 16 Apr. 2012: n.pag. www. the millions.com. Web. 30 May 2012.

Englander, Nathan. What We Talk About When We Talk About Anne Frank. London: Wiedenfeld \& Nicolson, 2012. Print.

Engeström, Yrjö. Learning by Expanding: An Activity-Theoretical Approach to Developmental Research. Helsinki: Orienta-Konsultit, 1987. Print.

Erpenbeck, Jenny. Visitation. Trans. Susan Bernofsky. London: Portobello Books, 2011. Print. Fenton, James. The Memory of War and Children in Exile: Poems 1968-1983. Harmondsworth, U.K.: Penguin Books, 1983. Print.

Ferguson, N.D. “No Smell of Roses." Letter. Metro (NZ) August 1991: 18. Print. 
Franklin, Ruth. A Thousand Darknesses: Lies and Truth in Holocaust Fiction. Oxford: Oxford University Press, 2011. Print.

---. "The Long View: A Rediscovered Master of Holocaust Writing." The New Yorker 31 Jan. 2011: 74-79. Print.

Freiberg, Freda. Rev. of Holocaust Remembrance in Australian Jewish Communities, 1945-2000, by Judith Berman. Australian Humanities Review Dec. 2001: n.pag. www.australianhumanitiesreview.org. Web. 14 Feb. 2011.

Friedlander, Saul. Memory, History and the Extermination of the Jews of Europe. Bloomington and Indianapolis: Indiana University Press. 1993. Print.*

---. When Memory Comes. Trans. Helen R. Lane. Madison: The University of Wisconsin Press. 1979. Print.*

Fromm, Erich. Beyond the Chains of Illusion: My Encounter with Marx and Freud. London: Continuum, 2006. Print.

---. The Fear of Freedom. London: Routledge, 2002. Print.

Funder, Anna. All That I Am. Camberwell: Penguin Group (Australia), 2011. Print.

Gadd, Kathleen M. From Ur to Rome. London: Ginn and Co., 1937. Print.

Greaney, Patrick. " Aestheticization and the Shoah: Heimrad Bäcker's transcript." New German Critique 109 (2010): 27-51. Print.

Grinblat, Kathy (ed.) Children of the Shadows: Voices of the Second Generation. Crawley: University of Western Australia Press. 2002. Print.*

Grossman, David. "Confronting the Beast." The Guardian 15 Sept. 2007: n. pag. www.guardian.co.uk. Web. 23 July 2012. 
Halbwachs, Maurice. The Collective Memory. Trans. Francis J. Ditter, Jr. and Vida Yazdi

Ditter. New York: Harper \& Row, 1980. Print.

Jacobson, Howard. The Finkler Question. London: Bloomsbury, 2010. Print.

Jenner, Lynn. Dear Sweet Harry. Auckland: Auckland University Press, 2010. Print.

Kaiser, Menachem. "The Holocaust's Uneasy Relationship with Literature.” The Atlantic Dec.

2010: n. pag. www.theatlantic.com. Web. 18 April 2012.

Kakutani, Michiko. "Bending the Truth in a Million Little Ways." The New York Times 17 Jan. 2006: n.pag. www.nytimes.com. Web. 27 Jan. 2012.

Kavenna, Joanna. Rev. of All That I Am, by Anna Funder. The Observer 4 Sept. 2011: n.pag. www.guardian.co.uk. Web. 14 Dec. 2011.

Kelly, Stewart. "Long live The Death of the Author." The Guardian 21 Feb. 2012: n.pag. www.guardian.co.uk. Web. 23 Feb. 2012.

King, Michael. "Tread Softly: Biography and Compassionate Truth." Tread Softly for You Tread on My Life: New and Collected Writings, by Michael King. Auckland: Cape Catley, 2001: 9-17. Print.

---. Being Pakeha Now: Reflections and Recollections of a White Native. Auckland: Penguin Books, 1999. Print.

"Kiwis 'incredibly welcoming but you had to become like Pakeha New Zealanders.'" The Dominion Post 11 Feb. 2012: C5. Print.

Klier, Freya. Promised New Zealand: Fleeing Nazi Persecution. Dunedin: Otago University Press, 2009. Print.

Kundani, Hans. Rev. of W. G. Sebald. Die Dialektische Imagination, by Ben Hutchinson. The Times Literary Supplement 9 April 2010: 30. Print. 
Lang. Berel. Post-Holocaust: Interpretation, Misinterpretation, and the Claims of History. Bloomington: Indiana University Press, 2005. Print.

Lawson, Tom, and James Jordan. eds. The Memory of the Holocaust in Australia. London: Vallentine Mitchell, 2007. Print.

Lanzmann, Claude. Dir. Les Films Aleph. 1985. Film.*

Leibman, Stuart. (ed.) Claude Lanzmann's Shoah: Key Essays. New York: Oxford University Press Inc. 2007.*

Levi, Primo. If Not Now When? Trans. William Weaver. London: Abacus, 1987. Print.

---. If This Is a Man and The Truce. Trans. Stuart Woolf. London: Everyman's Library, 2000. Print.

Leyner, Mark. “A Bug's Life. Really.” The New York Times 9 Mar. 2008: n. pag. www.nytimes.com. Web. 27 Jan 2012.

Littell, Jonathan. The Kindly Ones. Trans. Charlotte Mandell. New York: Harper Collins, 2009. Print.*

Lord Russel of Liverpool. The Scourge of the Swastika. London: Cassell, 1956. Print. Lüdtke, Alf. (ed.) The History of Everyday Life: Reconstructing Historical Experiences and Ways of Life. Trans. William Templer. Princeton: Princeton University Press, 1995. Print.*

Markson, David, Reader's Block. Normal,II.: Dalkey Archive Press, 1996. Print.

Mathé, Sylvie. "The 'grey zone' in William Styron's Sophie's Choice." Études Anglaises 4. (2004): n. pag. www.cairn.info. Web. 20 Dec. 2010.

Matthews, Philip. “Michael King.” New Zealand Listener 18 Oct. 2003: n. pag. www.listener.co.nz. Web. 14 June 2012. 
McKinnon, lan. “UN Holocaust Remembrance Day 2012." The Bulletin. Wellington: Temple Sinai Wellington Progressive Jewish Congregation. March 2012. 15. Print.

Mendelsohn, Daniel. "Stolen Suffering." The New York Times 9 Mar. 2008: n.pag. www.nytimes.com. Web. 27 Jan. 2012.

Michaeli, Merav. "Tony Judt's Final Word on Israel." The Atlantic October 2011: n.pag. www.theatlantic.com. Web. 14 May 2012.

Modiano, Patrick. The Search Warrant. Trans. Joanna Kilmarton. London: The Harvill Press, 2000. Print.

Morris, Paul. "Ikey" and I." Rev. of At the Edge of Memory: A Family Story, by Michael King. New Zealand Books Oct. 2002: 5-6. Print.

Moskovitz, Sarah. For New Zealand Poets: Milkcan Saved Poetry. 2011. Print.

Motola, Gabriel. "The Art of Fiction No. 140, Primo Levi." The Paris Review Spring 1995:

n.pag. www.theparisreview.org. Web. 5 Aug. 2011.

Mulvany, Nancy C. Indexing Books. Chicago: University of Chicago Press, 1994. Print.

Nagel, Thomas. "Tony Judt: The Distinctions." Rev. of The Memory Chalet, by Tony Judt. The New York Review of Books 10 Feb. 2011: n. pag. www.nybooks.com. Web. 25 Jan. 2012.

"Our Sponsors." wwf.org.nz. n.p., n.d. Web. 1 May 2012.

Packer, George. "The Unconsoled: A Writer's Tragedy, and a Nation's." The New Yorker 27 Sept. 2010: 51-61. Print.

Pamuk, Orhan, The Museum of Innocence. Trans. Maureen Freely. New York: Alfred A. Knopf, 2009. Print.

---. The Naive and Sentimental Novelist. 2010. Trans. Nazim Dikbaş. Camberwell: Penguin Group (Australia), 2011. Print. 
Phillips, Mark. "Histories, Micro - and Literary: Problems of Genre and Distance." New Literary History 34.2 (2003): 211-229. Web. 2 Jun. 2013.*

Powers, Denise. "Fresco Fiasco: Narratives of National Identity and the Bruno Schulz Murals of Drogobych." East European Politics and Societies 17 (2003): 622-653. Web. 13 Sept. 2012.

Regan, Mike, Bob Pope, and Susan Isaacs. The Deckston Legacy. Wellington: New Zealand Jewish Chronicle Publications, 2005. Print.

Reznikoff, Charles. Holocaust. Boston: David R. Godine, 2007. Print.

Rudolf, Anthony. "Exceptional." Rev. of Transcript, by Heimrad Bäcker and of Holocaust, by Charles Reznikoff. The Times Literary Supplement 16 July 2010. Print.

Safran Foer, Jonathan. Tree of Codes. London: Visual Editions, 2011. Print.

Sannino, Annalisa, Harry Daniels and Kris D. Gutiérrez, eds. Learning and Expanding with Activity Theory. Cambridge: Cambridge University Press, 2009. Print.

Schuler, Annabel. "Michael King: Journalist.” MA thesis. University of Canterbury, 2006. Print.

Sebald, W. G. After Nature. Trans. Michael Hamburger. New York: The Modern Library, 2002. Print.

---. The Emigrants. Trans. Michael Hulse. London: The Harvill Press, 1996. Print.

---. On the Natural History of Destruction. Trans. Anthea Bell. New York: The Modern Library, 2004. Print.

Sebald, W. G. (Poems) and Tripp, J. P. (Lithographs). Unrecounted. Trans. Michael Hamburger. New York: New Directions, 2004. Print.

Self, Will. "The Good German: Absent Jews and Invisible Executioners: W. G. Sebald and the Holocaust." The Times Literary Supplement 22 Jan 2010: 13-15. Print. 
Sheppard, Ruth. Explorer of the Mind: The Illustrated Biography of Sigmund Freud. London: Andre Deutsch, 2012. Print.

Shields, David. Reality Hunger: A Manifesto. Camberwell: Penguin Group, 2010. Print.

Solomons, Natasha. Mr Rosenblum's List or Friendly Guidance For the Aspiring Englishman. London: Sceptre, 2010. Print.

Spiegelman, Art. MetaMaus. London: Viking, Penguin Books, 2011. Print and DVD.

Styron, William. Sophie's Choice. London: Corgi Books, 1980. Print.

Sucher, Cheryl Paul. The Rescue of Memory. New York: Scribner. 1997. Print.*

Tempian, Monica, and Hal Levine, eds. Exile-Identity-Language. Proceedings of the iv. Jewish Heritage and Culture Seminar. Wellington: Victoria University of Wellington, 2009. Print.

The Lost Princess \& Other Kabbalistic Tales of Rebbe Nachman of Breslov. Trans. Rabbi Aryeh Kaplan. Woodstock Vermont: Jewish Lights Publishing, 2005. Print.

Thompson, Michael. Rubbish Theory. Oxford: Oxford University Press, 1979. Print.

Thomson, Margie. "Michael King: At the Edge of Memory." Rev. of At the Edge of Memory, by Michael King. New Zealand Herald 8 April 2002: n. pag. www.nzherald.co.nz. Web. 14 June 2012.

Tolstoy, Leo. Anna Karenina. Trans. Louise and Aylmer Maude. 1877. Oxford: Oxford University Press, 1999. Print.

Tory, Avraham. Surviving the Holocaust: The Kovno Ghetto Diary. Trans. Jerzy Michalowcz. Cambridge: Harvard University Press. 1990. Print.*

Toynton, Evelyn. "The Other Side of Silence." Rev. of The Emergence of Memory: Conversations with W. G. Sebald, by Lynne Sharon Schwartz. Review-a-Day 26 March 2010: n.pag.reviews@e-mail.powells.com.Web. 29 Mar. 2010. 
Turnovsky, Fred. Turnovsky: Fifty Years in New Zealand. Wellington: Allen \& Unwin, 1990.

Print.

University of Southern California Shoah Foundation Institute for Visual History and Education. dornsife.usc.edu .n.p., n.d. Web. 22 Oct. 2012.

Uris, Leon. Exodus. New York: Doubleday \& Company, 1959. Print.

Vicente, Mercedes. "True Stories/Scripted Realities 10 March-24 June 2012." Exhibition Programme, New Plymouth: Govett-Brewster Art Gallery, 2012. Print.

Vonnegut, Kurt, Slaughterhouse Five. 1969. New York: Dell Publishing, 1991. Print.

Wagowska, Halina. The Testimony. Melbourne: Hardie Grant Books, 2011. Print.

Webber, Jonathan. Rediscovering Traces of Memory: The Jewish Heritage of Polish Galicia. Bloomington: Indiana University Press, 2009. Print.

Weiss, Lotte. My Two Lives. Netley, South Australia: Griffen Press, 2003. Print.

Wells, Peter. The Hungry Heart: Journeys with William Colenso. Auckland: Random House, 2011. Print.

Wichtel, Diana. "Driving to Treblinka." Listener 8 Jan 2011: 20-24. Print.

Winter, Jay. Remembering War: The Great War Between Memory and History in the Twentieth Century. New Haven and London: Yale University Press, 2006. Print.

Wood, James. "Broken Record: A Historical Novel at War with Itself." Rev. of $H H h H$, by Laurent Binet. The New Yorker 21 May 2012: 74-76. Print.

Young, James E. At Memory's Edge: After-Images of the Holocaust in Contemporary Art and Literature. New Haven and London: Yale University Press, 2000. Print.

Young, James E. The Texture of Memory: Holocaust Memorials and Meaning. New Haven and London: Yale University Press, 1993. Print.

Zable, Arnold. Jewels and Ashes. Carlton North: Scribe Publications. 1991.* 
